UNIVERSIDADE DE SÃO PAULO

FACULDADE DE EDUCAÇÃO

HELOISA GONÇALVES JORDÃO

A produção de textos em tela por alunos recém-alfabetizados

São Paulo

2019 
HELOISA GONÇALVES JORDÃO

\title{
A produção de textos em tela por alunos recém-alfabetizados
}

\author{
Versão corrigida
}

Tese apresentada ao Programa de Pós-Graduação em Educação, Linguagem e Psicologia da Faculdade de Educação da Universidade de São Paulo como requisito parcial para obtenção do título de Doutora em Educação.

Área de Concentração: Educação, Linguagem e Psicologia

Orientador: Prof. Dr. Sandoval Nonato Gomes Santos

São Paulo

2019 
Autorizo a reprodução e divulgação total ou parcial deste trabalho, por qualquer meio convencional ou eletrônico, para fins de estudo e pesquisa, desde que citada a fonte.

\section{Catalogação da Publicação}

Ficha elaborada pelo Sistema de Geração Automática a partir de dados fornecidos pelo(a) autor(a) Bibliotecária da FE/USP: Nicolly Soares Leite - CRB-8/8204

Jordão, Heloisa Gonçalves. A produção de textos em tela por alunos recém-alfabetizados / Heloisa Gonçalves Jordão; orientador Sandoval Nonato Gomes Santos. -- São Paulo, 2019. 233 p.

Tese (Doutorado - Programa de Pós-Graduação Educação, Linguagem e Psicologia) -- Faculdade de Educação, Universidade de São Paulo, 2019.

1. alfabetização. 2. produção de textos. 3. consciência metalinguística. 4. instrumentos de escrita.

5. computador. I. Gomes Santos, Sandoval Nonato, orient. II. Título. 
JORDÃO, Heloisa Gonçalves. A produção de textos em tela por alunos recém-alfabetizados.

2019. 233 f. Tese (Doutorado em Educação) - Faculdade de Educação, Universidade de São Paulo, São Paulo, 2020.

Aprovado em:

Banca Examinadora

Prof. Dr. Sandoval Nonato Gomes Santos

Instituição: Universidade de São Paulo

Julgamento:

Prof. Dr. Clécio dos Santos Bunzen Júnior

Instituição: Universidade Federal de Pernambuco

Julgamento:

Prof. Dr. Eduardo Calil de Oliveira

Instituição: Universidade Federal de Alagoas

Julgamento:

Profa. Drạ. Cláudia Lemos Vóvio

Instituição: Universidade Federal de São Paulo

Julgamento:

Profa. Dra . Raquel Salek Fiad

Instituição: Universidade Estadual de Campinas

Julgamento: 
A Fernando e Marina, minha família. 


\section{AGRADECIMENTOS}

Ao Prof. Dr. Sandoval Nonato Gomes Santos, que há dez anos acredita em meu trabalho como professora e pesquisadora. Por ter me orientado com sabedoria, me compreendido com paciência e, acima de tudo, por ser um colega que acredita na construção de uma educação pública de qualidade.

Ao Prof. Dr. Clécio dos Santos Bunzen Júnior e ao Prof. Dr. Eduardo Calil, pelas estimadas e valiosas contribuições ao meu trabalho no momento de sua Qualificação e por aceitarem participar da defesa deste trabalho.

À Profạ Drạ Cláudia Lemos Vóvio, por, há anos, compartilhar ideias e leituras que tanto auxiliam em meu aprimoramento profissional e intelectual. Por demonstrar confiança em meu trabalho e por aceitar participar em minha banca de defesa.

À Profa Drạ Raquel Salek Fiad, que tanto admiro o trabalho que desenvolve, por gentilmente ter aceitado participar em minha banca de defesa.

À Profa Drạ Anna Christina Bentes, à Profạ Drạ Eliane Gouvêa Lousada, ao Prof. Dr. Emerson de Pietri e à Profa Drạ Márcia Rodrigues de Souza Mendonça, pelo aceite em fazerem parte da Suplência de defesa e pelo apoio assim demonstrado a este estudo.

Aos alunos, professores e gestores da E.M.E.F. Theodomiro Dias, que me ensinaram muito todos os dias em que trabalhamos juntos. Sem eles este trabalho não teria sido realizado.

À minha grande mestre Profạ Ms. Katsue Hamada Zenun, por ter me ensinado que o exercício da docência e da pesquisa implica muito conhecimento, mas acima de tudo, precisa ter como base a construção das relações de respeito e amizade.

Ao CNPQ, pelo apoio financeiro concedido ao longo dos 12 últimos meses de desenvolvimento da pesquisa. 


\section{RESUMO}

JORDÃO, Heloisa Gonçalves. A produção de textos em tela por alunos recém-alfabetizados.

2019. 233 f. Tese (Doutorado em Educação) - Faculdade de Educação, Universidade de São Paulo, São Paulo, 2020.

Esta tese tem como objetivo descrever e analisar práticas de produção de textos escritos por alunos recém-alfabetizados com o uso do computador e do editor de textos. Considerando que alunos desta etapa de escolarização apresentam características únicas, apontamos problemas de três naturezas: i) a representação ortográfica das palavras, ii) o domínio da competência gráfico-técnica e iii) os saberes vinculados aos encadeamentos entre palavras e frases que irão compor o texto final (SOARES, 2003). Amparados nos estudos desenvolvidos por Frade (2011b) e Frade e Galvão (2016), temos como hipótese que a materialidade dos instrumentos de escrita envolve uma correspondência física e mental por parte do escrevente e, consequentemente, as transformações nas tecnologias para inscrever acarretam no domínio de novos gestos e relações com a cultura escrita, o que implicaria a necessidade de promover, em aulas de língua materna, o ensino desses novos gestos que constituem o saber-fazer dos escritores da atualidade. Com o intuito de subsidiar a reflexão sobre a influência dos instrumentos de escrita nas práticas sociais e escolares apresentamos uma retrospectiva histórica do ensino da escrita na escola com foco nos materiais disponíveis para inscrever e receber a escrita. (TANK de ESTRADA, 1988, 1990; A.M. CHARTIER, 2007, 2011, 2016; RAZZINI, 2008). Apoiados em Soares (2016), Barbeiro e Pereira (2011) e Calil e Pereira (2018), abordamos as especificidades do ensino da produção de textos por alunos em processo do desenvolvimento de automatismos gráficos e ortográficos da escrita e discutimos inserção dos artefatos digitais em contextos escolares (DUDENEY, HOCKLY, PEGRUM 2016). Os dados foram gerados em situações reais de ensino desenvolvidos em uma escola pública, caracterizando um estudo qualitativo, optamos pela abordagem microgenética em uma perspectiva enunciativa para analisar os comentários feitos por alunos recém-alfabetizados durante a produção de texto em tela (GÓES, 2000). Os resultados indicam que o desenvolvimento da produção de textos para alunos recémalfabetizados depende, no âmbito linguístico, de tarefas que fomentem o desenvolvimento de competências relacionadas a reflexão metalinguística no nível lexical e gramatical. No âmbito técnico-gráfico, o uso de computadores e editores de textos envolvem novos gestos que precisam ser considerados como novos objetos de ensino. Constatou-se que alunos com melhor domínio de escrita detinham um pequeno conjunto de conhecimentos acerca do uso dos periféricos e do software. Já os alunos com dificuldades na escrita apresentaram pouca familiaridade no manejo dos instrumentos o que acarretou problemas ainda mais complexos no desenvolvimento de suas produções escritas.

Palavras-chave: Alfabetização. Produção de textos. Consciência metalinguística. Instrumentos de escrita. Computador. 


\begin{abstract}
JORDÃO, Heloisa Gonçalves. The production of texts on screen by newly literate students. 2019.

233f. Tese (Doutorado em Educação) - Faculdade de Educação, Universidade de São Paulo, São Paulo, 2020.

This thesis aims to describe and analyze text production practices written by pairs of newly literate students of the 3rd year of elementary school using the computer and the text editor. Considering that students at this stage of schooling have unique characteristics, we point out problems of three natures: i) orthographic representation of words, not yet automated, ii) mastery of graphic-technical competence and iii) the knowledge linked to the chaining between words and phrases that will compose the final text (SOARES, 2003). Supported by the studies developed by Frade (2011b) and Frade and Galvão (2016), we hypothesize that the materiality of writing instruments requires a physical and mental correspondence adjusted to the object and, consequently, when changing the technology to enroll, it becomes It is necessary for the subject writer to master new gestures and develop new modes of relationship with written culture, so it would be necessary to promote the teaching of written production in school so that these new gestures, which constitute the know-how of today's writers, can be learned. In order to support the reflection on the influence of writing instruments on social and school practices, we present a historical retrospective of the teaching of writing at school, focusing on the materials available to enroll and receive writing (TANK de ESTRADA, 1988, 1990; A.M. CHARTIER, 2007, 2011, 2016; RAZZINI, 2008). Supported by Soares (2016), Barbeiro and Pereira (2011), Calil and Pereira (2018), we address the specificities of the teaching of text production by students in the process of developing graphical and orthographic automations. writing and discuss insertion of digital artifacts in school contexts (DUDENEY, HOCKLY, PEGRUM 2016). The data were generated in real teaching situations of a public school in the city of São Paulo, characterizing a qualitative study because it involves the comprehensive interpretation of the processes through the analysis of situated interactions. We opted for the microgenetic approach from an enunciative perspective to analyze the comments made by newly literate students during the production of text on screen (GÓES, 2000). The results indicate that the teaching of text production for newly literate students depends, in the linguistic context, on tasks that foster the development of skills related to metalinguistic reflection at the lexical and grammatical level. In the technical-graphic area, the use of computers and text editors involves new gestures that need to be considered as new teaching objects in text production classes. It was found that students with better mastery of writing had a small set of knowledge about the use of peripherals and software. Already students with writing difficulties had little familiarity in the handling of the instruments which led to even more complex problems in the development of their written productions.
\end{abstract}

Keywords: Literacy. Textual production. Metalinguistic awareness. Writing instruments, Computer. 


\section{LISTA DE ILUSTRAÇÕES}

Figura 1 - Os diferentes papéis do computador na produção de textos

Figura 2 - Leiaute padrão dos Laboratórios de Informática Educativa 102

Figura 3 - Vista ampla do ambiente Laboratório de Informática Educativa 112

Figura 4 - Uso da televisão no ambiente Laboratório de Informática Educativa 113

Figura 5 - Bloqueio dos computadores dos alunos por meio do software de gestão da rede .. 114

Figura 6 - Estrutura base de uma sequência didática 125

Figura 7 - AL/AS: Produção de texto inicial 137

Figura 8 - AL/AS: Textualização/OT composicional - função sintática da palavra 138

Figura 9 - AL/AS: OT composicional (concordância verbal) 139

Figura 10 - ARA/ALU: Produção de texto inicial 142

Figura 11 - ARA/ALU - Continuação da produção de texto 142

Figura 12 - ARA/ALU: Problema ortográfico lexical 144

Figura 13 - ARA/ALU: Problema técnico-gráfico - mudança de linha 144

Figura $14-\mathrm{AB} / \mathrm{AV}$ : Texto inicial 146

Figura 15 - AB/AV: Textualização - segmentação de palavras 148

Figura $16-\mathrm{AB} / \mathrm{AV}$ : Alunos observam o surgimento do traço vermelho do editor de texto, indicando problemas de ortografia 149

Figura 17 - AB/AV: Reflexão sobre segmentação e ortografia, em movimento de revisão gerado pelo corretor automático do editor de texto 149

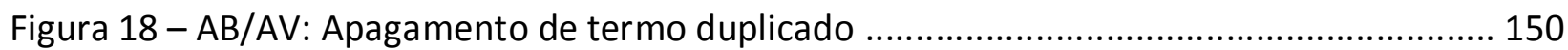

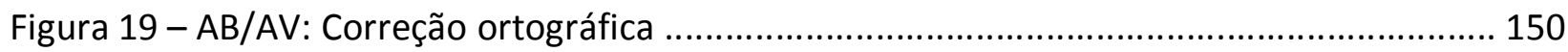

Figura 20 - AB/AV: Escrita de palavra desconhecida …………………………………..... 153

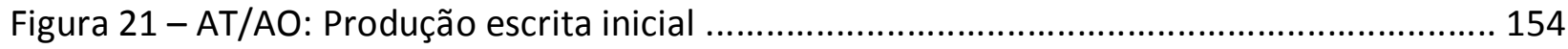

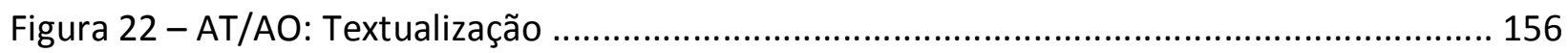

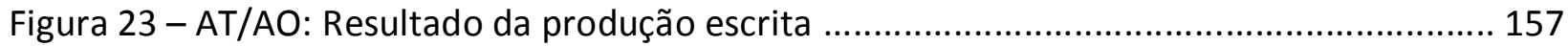

Figura 24 - AR/ALA: Textualização e problemas de organização sintático/gramatical .............. 158 
Figura 25 - AR/ALA: Textualização e problemas de organização sintática

Figura 26 - AR/ALA: Resultado na produção na atividade 2

Figura 27 - ALF/AK: Segmentação e posicionamento do cursor

Figura 28 - ALF/AK: Resolução do problema de segmentação 162

Figura 29 - ALF/AK: Problema de segmentação e seleção de letra em lugar de posicionamento

do cursor 163

Figura 30 - AG/AW: Problema ortográfico em palavra termo do jogo (1 a tentativa) 165

Figura 31 - AG/AW: Problema ortográfico em palavra termo do jogo (2 ${ }^{\text {a }}$ tentativa) 165

Figura 32 - AG/AW: Escrita de palavra termo do jogo (3a tentativa) 165

Figura 33 - AGO/AW: Trecho lido e reformulado oralmente por AG 167

Figura 34 - AGO/AW: Sentença com seu final deletado para correção 167

Figura 35 - AGO/AW: Acréscimo do R final de infinitivo 167

Figura 36 - AGO/AW: Tentativa de inserção do diacrítico til (duplicação da vogal) 169

Figura 37 - AGO/AW: Tentativa de inserção do diacrítico til (duplicação da vogal e uso do acento agudo) 169

Figura 38 - AG/AW: Tentativa de inserção do diacrítico til (acento agudo) 169

Figura 39 - AG/AW: Inserção do diacrítico til 169

Figura 40 - AE/AG: Alunos buscando a foto no explorador de arquivos 171

Figura 41 - AE/AG: Foto em tamanho grande inserida no texto 172

Figura 42 - AE/AG: Ajuste da foto conforme diagramação do texto e escrita de legenda 172

Figura 43 - AE/AG: Problemas com a rolagem de tela (paginação) 173

Figura 44 - AE/AG: AE exemplificando a ação de ajustar o tamanho da imagem ao texto 174

Figura 45 - AE/AG: Aluna apontando o espaço para a segunda figura na diagramação

do texto 174

Figura 46 - AE/AG: Segunda imagem ajustada à diagramação do texto 175

Figura 47 - AL: Manuseio do teclado 187

Figura 48 - ARA: Manuseio do teclado

Figura 49 - ALU: Manuseio do teclado 188 


\section{LISTA DE TABELAS}

Quadro 1 - Relação de saberes colocados em funcionamento na prática de produção

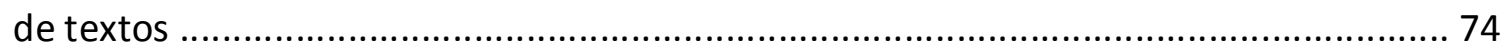

Quadro 2 - Problemas ortográficos lexicais e gramaticais .................................................. 75

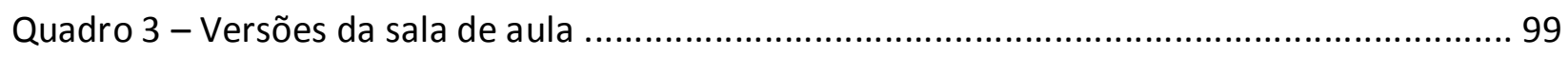

Quadro 4 - Resumo das atividades planejadas na sequência de ensino ............................... 124

Quadro 5 - Quadro sinóptico proposto por Cordeiro (2015) ........................................... 131

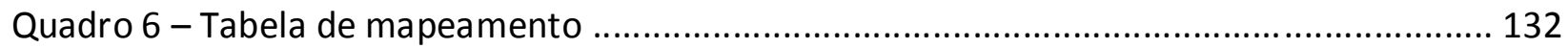

Quadro 7 - Relação de duplas, nível de proficiência, operação de produção textual e

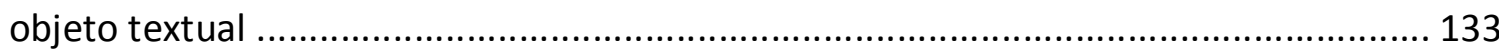

Quadro 8 - Normas de transcrição .......................................................................... 135

Quadro 9 - Transcrição do OT composicional de AL/AS: formula o texto oralmente, mas não redige, e função sintática da palavra ...................................................... 137

Quadro 10 - Transcrição do OT composicional de AL/AS: concordância verbal ..................... 138

Quadro 11 - Transcrição do OT técnico-gráfico de ARA/ALU: alternar linhas e deletar

Letras

Quadro 12 - Transcrição do OT técnico-gráfico de ARA/ALU: alternar linhas e deletar

Letras

Quadro 13 - Transcrição do objeto textual ortográfico de ARA/ALU: redigir palavras com sílabas não canônicas

Quadro 14 - Transcrição do OT ortográfico de ARA/ALU: apoio na oralidade 143

Quadro 15 - Transcrição do objeto textual composicional de AB/AV: organização das informações no texto injuntivo 145

Quadro 16 - Transcrição do OT ortográfico de AB/AV: segmentação 147

Quadro 17 - Transcrição do objeto textual técnico-gráfico de AB/AV: corretor automático do editor 148

Quadro 18 - Transcrição do OT composicional de AB/AV: estrutura frasal 149

Quadro 19 - Transcrição do OT composicional de AB/AV: estrutura frasal (continuação) 150 
Quadro 20 - Transcrição do OT ortográfico de AB/AV: escrita de palavra desconhecida

Quadro 21 - Transcrição do OT composicional e ortográfico de AB/AV: inserção de

novas informações e escrita de sílaba não canônica

Quadro 22 - Transcrição do OT composicional de AT/AO: estrutura frasal

Quadro 23 - Transcrição do OT composicional de AT/AO: estrutura frasal (continuação) 156

Quadro 24 - Transcrição do OT composicional, técnico-gráfico e ortográfico de ALA/AR:

organização sintática, mudança de linha e segmentação

Quadro 25 - Transcrição do OT ortográfico e técnico-gráfico de ALF/AK: segmentação e manejo do mouse - posicionamento do cursor

Quadro 26 - Transcrição do OT ortográfico e técnico-gráfico de ALF/AK: segmentação e manejo do mouse - posicionamento do cursor (continuação)

Quadro 27 - Transcrição do OT ortográfico AGO/AW: homofonia 164

Quadro 28 - Transcrição do OT composicional, ortográfico e técnico-gráfico de AGO/AW ..... 166

Quadro 29 - Transcrição do OT técnico-gráfico AE/AG: paginação 170

Quadro 30 - Transcrição do OT técnico-gráfico AE/AG: inserção de fotos no texto 175 
SUMÁRIO

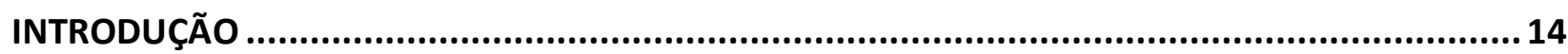

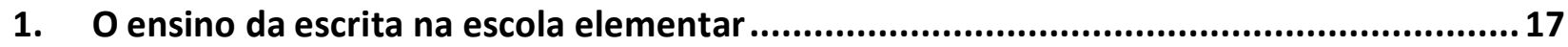

1.1. Retomada histórica do ensino da escrita na escola elementar da Europa Católica ....20

1.2. O ensino da leitura e da escrita na América Latina e no Brasil ...................................28

1.2.1. O processo de emancipação política das colônias e os modos de ler e escrever 34

1.3. O quadro-negro e o ensino simultâneo: a interação didática ......................................36

1.4. As inovações e permanências no ensino da leitura e da escrita no século XIX ............41

1.4.1. O caderno: prova material do trabalho de ensino .............................................47

1.5. Os novos suportes e o ensino da escrita ........................................................................51

2. A produção de texto na escola no Ciclo de Alfabetização: do papel para a tela...............58

2.1. O espaço de escrita e os mecanismos de produção ....................................................59

2.2. As diferentes facetas do ensino da escrita: da escrita de palavras à produção de textos

2.2.1. O processo de produção de textos para alunos recém-alfabetizados ..................71

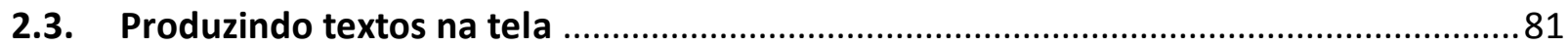

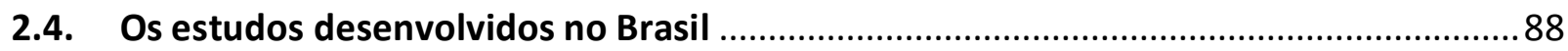

3. Instrumentos digitais de escrita e interação em sala de aula .......................................95

3.1. O espaço da sala de aula: mobiliário e materiais de escrita ........................................96

3.2. O dispositivo comunicativo em sala de aula ...............................................................97

3.3. O uso pedagógico dos computadores nas escolas públicas brasileiras .......................99

3.3.1. A interação nos Laboratórios de Informática Educativa: o espaço e o tempo ...101

3.3.2. As tarefas desenvolvidas em Laboratório de Informática Educativa ...................105

4. O contexto de pesquisa: escola e organização do sistema municipal de ensino ............ 108

4.1. O ciclo de alfabetização: espaços e materiais de escrita ..........................................109

4.2. O Laboratório de Informática Educativa da unidade escolar ...................................111

4.3. A organização em rede ......................................................................................113

5. A produção de texto nos documentos que orientam o ensino no 3 ano ..................... 115

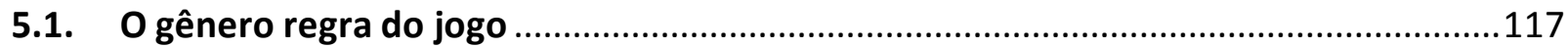

6. O processo de geração dos dados ...................................................................... 121

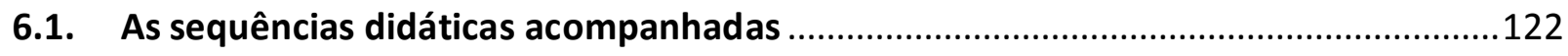

7. Metodologia, unidades de análise e tratamento do corpus ................................... 127 
7.1. Abordagem microgenética em uma perspectiva enunciativa

7.2. Unidades de análise

7.3. Tratamento dos dados e corpus analisado

7.4. Normas de transcrição

8. Análise

8.1. Desenvolvimento da produção inicial (atividade 1)

8.1.1. Trabalho da dupla AL e AS

8.1.2. Trabalho da dupla ALU e ARA

8.2. Revisitando o texto pela primeira vez (atividade 2) ............................................146

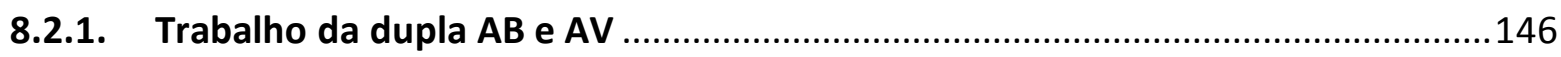

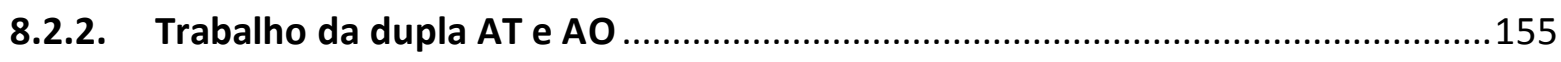

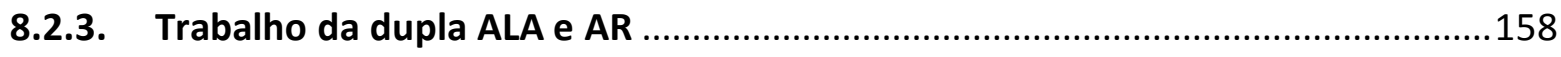

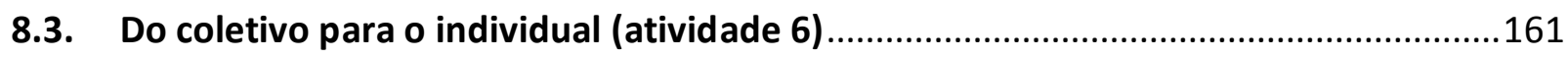

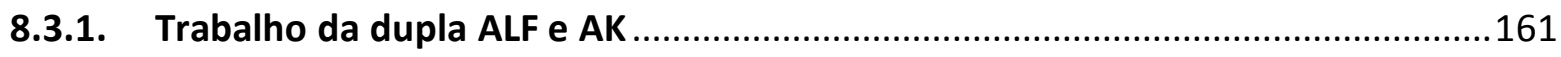

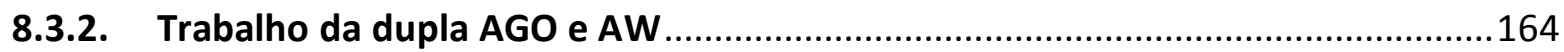

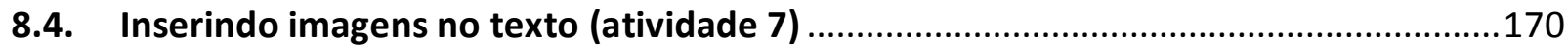

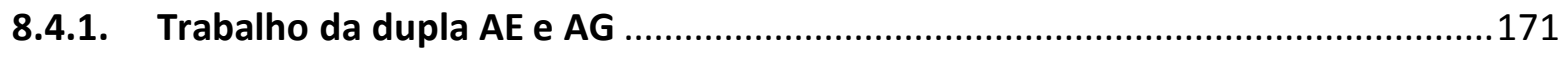

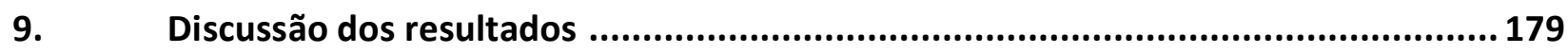

9.1. Objetos textuais envolvendo aspectos do domínio do sistema alfabético e das convenções ortográficas

9.2. Objetos textuais envolvendo aspectos composicionais ..........................................183

9.3. Objetos textuais envolvendo aspectos técnico-gráficos ............................................185

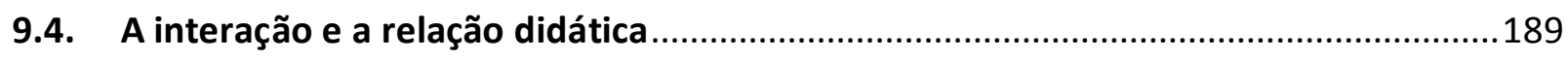

CONCLUSÃO ....................................................................................................... 191

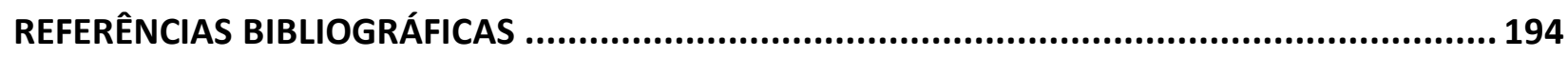

ANEXO A - CURRÍCULO DE LÍNGUA PORTUGUESA PARA OS $3^{\circ 5}$ ANOS. DOCUMENTO RECOLHIDO EM CAMPO .................................................................................... 205

ANEXO B - TERMO DE CONSENTIMENTO LIVRE E ESCLARECIDO .................................... 207

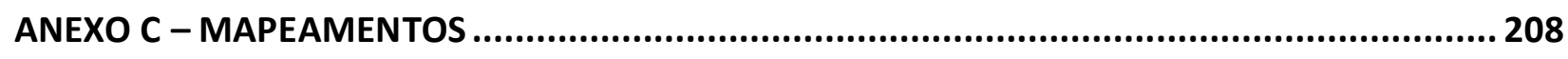




\section{INTRODUÇÃO}

Este estudo nasce a partir de observações feitas ao longo de muitos anos no trabalho com o Ensino Fundamental de escolas públicas da rede municipal, quando constatamos que as turmas finais do Ciclo de Alfabetização costumam ser encaradas pelos professores como turmas complexas, justamente por estarem em uma etapa marcada pelo incremento de novas competências relacionadas à leitura e escrita proficientes. Ou seja, é uma etapa em que se espera, conforme preveem os currículos e demais documentos norteadores do ensino, que os alunos já tenham automatizado boa parte dos saberes envolvidos nas competências gráfica e ortográfica e estejam prontos para se engajarem de maneira mais qualitativa em atividades efetivas de produção e leitura de textos diversos. Quando colocados no papel de produtores de texto, os novos escritores irão lidar tanto com o sistema notacional - que envolve as representações grafofônicas, com suas dimensões gráficas e ortográficas ainda não automatizadas - quanto com o próprio processo de geração do texto e transcrição, que exige conhecimentos semânticos, sintáticos, morfológicos, de pontuação e acentuação e saberes vinculados ao encadeamento entre palavras e frases que irão compor o texto final.

No entanto, pesquisar sobre o processo de aprendizagem da produção escrita não implica apenas analisar os aspectos linguísticos nela envolvidos. De acordo com Soares (2016), os métodos para ler e escrever surgiram e se consolidaram na escola elementar de modo muito afinado com o material que se dispunha e não estavam necessariamente relacionados a teorias acadêmico-científicas. Sendo assim, este estudo propõe a análise do processo de produção escrita nos suportes e instrumentos de escrita da atualidade, ou seja, com o uso de computadores e softwares de edição de textos e imagens. De acordo com Frade (2011b), as transformações nas tecnologias de escrita demandam novos gestos e possibilidades cognitivas e, por extensão, em novos modos de ensinar e aprender. A autora justifica essa afirmação, pois os instrumentos alteram os modos de relacionamento dos sujeitos com a cultura escrita e, em outra instância, com o próprio conhecimento e com uma instituição encarregada de transmitilo: a escola.

Desse modo, no capítulo 1, apresentaremos a retrospectiva histórica da relação entre o ensino da escrita e a escola elementar. Analisaremos os modos como os variados suportes e 
instrumentos de escrita foram incorporados ao cotidiano das salas de aula da escola elementar e como sua inserção está intimamente relacionada com a organização dos métodos de ensino da língua escrita vigentes, bem como a constituição da própria instituição escolar: espaço, tempo e relação didática. Observaremos como razões técnicas e econômicas geralmente concorrem com justificativas pedagógicas no que tange às práticas escolares envolvendo a escrita.

No capítulo 2, explicitaremos a base teórica que fundamenta tanto as transformações decorrentes do ensino da escrita do papel para a tela quanto as especificidades em relação à aprendizagem da produção de textos dos alunos do 3ㅇa ano. Construir representações ortográficas das palavras é um marco que permite que o aluno seja considerado "alfabetizado", mas quando ele se torna um efetivo "produtor de textos escritos"? Assim, considerando as diferentes facetas envolvidas na produção fluente de textos, explicitaremos as competências metalinguísticas que os alunos, nesse processo de transição da escrita de palavras à escrita de textos, precisam desenvolver nas aulas de língua materna. Nesse processo, há o desenvolvimento de determinados gestos, pois a materialidade dos instrumentos de escrita exige uma correspondência física e mental ajustada ao objeto (FRADE; GALVÃO, 2016, p. 329). Nos escritores proficientes, essa relação com os instrumentos de escrita é uma habilidade automatizada, no entanto, para alunos do Ciclo de Alfabetização, ela representa saberes a serem apreendidos. Assim, refletiremos sobre as grandes operações envolvidas na produção de textos, os saberes de diferentes naturezas nela envolvidos e, sobretudo, o que muda quando se ensina a produzir textos na tela. Ao final, retomaremos os estudos desenvolvidos no Brasil sobre o ensino da escrita, nos anos iniciais, utilizando o computador e o editor de texto.

No capítulo 3, nos debruçaremos sobre a inserção de dispositivos digitais na escola, especialmente os computadores, apresentando inicialmente uma breve reconstituição do modo como eles estão sendo incorporados ao espaço escolar no contexto brasileiro e, de modo mais específico, da rede municipal de ensino da cidade de São Paulo. Em seguida, discutiremos as possibilidades de distribuição desses artefatos na escola e como eles influenciam na reconfiguração do leiaute dos ambientes de ensino, dos suportes e riscadores utilizados e, consequentemente, na dinâmica didática, apresentando de modo mais detalhado o modelo 
Laboratório de Informática Educativa, mais comum nas escolas brasileiras e locus do desenvolvimento desta pesquisa.

Nos capítulos 4 e 5, apresentaremos as características da escola municipal na qual os dados foram gerados, bem como as salas de 3으 ano que foram acompanhadas. São fornecidas informações acerca do Laboratório de Informática Educativa e os recursos disponíveis no ambiente. Abordaremos alguns pontos dos documentos que norteiam o ensino da escrita e produção de textos da rede municipal, de modo a subsidiar o processo de geração dos dados, em especial a eleição do gênero regra de jogo, objeto da construção da sequência didática acompanhada. O capítulo 6 descreverá a relação da pesquisadora com o contexto da pesquisa, a metodologia adotada e o processo de geração dos dados.

O capítulo 7 explicitará a metodologia, as unidades de análise e o tratamento do corpus gerado em campo destacando o caráter situado da pesquisa de modo a captar os processos significativos que se desenvolvem entre os alunos e a tarefa de produção de textos escritos no interior da rotina escolar regular de uma escola pública.

No capítulo 8, realizaremos a análise efetiva dos dados, apresentando as transcrições e imagens das produções textuais em desenvolvimento pelos alunos de 3o ano com o uso do computador e do editor de texto. De modo a preservar a lógica da sequência didática acompanhada, apresentaremos a análise conforme a organização cronológica na qual os dados foram gerados. Por fim, no capítulo 9, faremos uma discussão organizando os dados analisados a partir das unidades de análise previamente estabelecidas. 


\section{0 ensino da escrita na escola elementar ${ }^{1}$}

Há décadas, no mundo ocidental, a associação entre a escola e o ensino da escrita é tida como óbvia. Da mesma forma, o manejo dos instrumentos de escrita, como o lápis e a caneta, assim como o registro em suportes como caderno, folhas de linguagem e papel almaço, parece intrínseco à vida escolar. As competências relacionadas à leitura e à escrita, bem como a utilização dos elementos materiais envolvidos nessas práticas, estão tão imbricadas à cultura escolar que é praticamente impossível pensarmos a escola sem sua presença. No entanto, "ler, escrever e contar não foram sempre os fundamentos obrigatórios da instrução popular" (HÉBRARD, 2001, p. 116).

Para a reconstrução do uso dos instrumentos e suportes de escrita e suas relações com a formação da instituição escolar tal qual a conhecemos na atualidade, recorremos aos estudos desenvolvidos no campo da história da cultura escrita (GOMÉZ, 2003) e tomaremos a cultura escolar como ferramenta para o estudo das relações entre escola e cultura (JULIA, 2001; VIDAL, 2009). De modo a propor uma delimitação ainda maior, recorremos ao campo da história da alfabetização (FRADE, 2011b), que articula os dois campos anteriores debruçando-se de maneira específica sobre o ensino da leitura e da escrita na escola elementar.

Entendemos a história da cultura escrita conforme proposto por Goméz (2003), que a caracteriza como uma forma específica de história cultural cujo objetivo incide na interpretação das práticas sociais de escrever e ler. $\mathrm{O}$ autor salienta que a história da cultura escrita deve ser

\footnotetext{
1 Utilizaremos o termo "elementar" para caracterizar os anos iniciais da escolarização popular - ou seja, a escolarização voltada às classes populares - em oposição à etapa seguinte, denominada "colégio" ou "secundário", de caráter mais elitista, que representa os anos posteriores de estudo e em que se desenvolvem outras relações com a escrita (cf. JULIA, 2001; RAZZINI, 2008; VIDAL; GVIRTZ, 1998). Vale salientar o trabalho de Dominique Julia (2001, p. 26), o qual afirma que desde o século XVI, as ordens missionárias religiosas investiram-se da tarefa de educar para atingir a totalidade dos fiéis, tanto das elites quanto do povo, e aponta que é notória a divisão para cada grupo: ao povo destina-se somente o "ensino elementar no sentido próprio do termo (os elementos da fé)", e à elite, uma instrução voltada para a formação contínua, contemplando saberes das diversas áreas do conhecimento.
} 
abordada como história social e que se conceda uma especial relevância à análise das formas materiais do escrito ${ }^{2}$. Nas palavras do autor:

[...] a história da cultura escrita transcende a consideração da escrita como um mero sistema gráfico para questionar-se principalmente por suas diversas funções e consequentes práticas materiais, sempre tendo como referência as respectivas sociedades históricas e levando em conta que, a cada momento, a sociedade tem sido formada por analfabetos e alfabetizados. (GOMÉZ, 2003, p. 96, tradução nossa ${ }^{3}$ ).

De maneira complementar, tomaremos a cultura escolar no intuito de analisar o "conjunto de normas que definem conhecimentos a ensinar e condutas a inculcar e do conjunto de práticas que permitem a transmissão desses conhecimentos e a incorporação desses comportamentos" (JULIA, 2001, p. 10). Vidal (2009) propõe que nossa análise seja movida pelas "lentes da cultura escolar", com o intuito de não apenas ampliarmos nosso entendimento sobre o funcionamento interno da instituição escolar, mas também para compreendermos as relações estabelecidas historicamente entre escola, sociedade e cultura. Para tal, é necessário que se promova a reflexão sobre as relações de permanência e inovação das práticas escolares ${ }^{4}$, partindo de uma premissa dual que aborde tanto a cultura material como elemento constitutivo das práticas escolares quanto os sujeitos escolares como agentes sociais.

No desafio de compreender a conformação da cultura escolar em suas diferentes dimensões, sincrônicas e diacrônicas, é essencial distinguir os modos como ela se manifesta nos objetos produzidos pela e para a escola e nas práticas instaladas no seu interior pela ação dos sujeitos escolares. (VIDAL, 2009, p. 30, grifos nossos).

\footnotetext{
${ }^{2}$ Para uma análise sobre a história dos sistemas de escrita e as relações decorrentes da materialidade envolvida na escrita e as práticas sociais, destacam-se os estudos realizados pelo professor Luiz Carlos Cagliari (CAGLIARI, 1999a).

3 “[...] trasciende la consideración de la escritura como un mero sistema gráfico para interrogarse principalmente por sus distintas funciones y las consiguientes prácticas materiales, siempre em referencia a las respectivas sociedades históricas y teniendo em cuenta que em cada momento la sociedad há estado formada por alfabetizados y analfabetos" (GOMEZ, 2003, p. 96).

${ }^{4}$ Sobre a relação de permanências e inovações, Vidal marca como permanências determinados elementos perenes que imprimem marcas da forma escolar comuns a todas as escolas, no entanto, é necessário refinar o olhar para que no interior dessa forma o pesquisador seja capaz de enxergar os traços de inovação, que se distinguem de acordo com a cultura escolar de cada instituição: "A perspectiva de Julia (Dominique) combina a atenção às normas ao interesse pelas práticas, tentando perceber como professores e alunos traduzem as regras em fazeres, expurgando diretrizes que consideram inadequadas e selecionando dispositivos em detrimento de outros, numa verdadeira triagem e reconversão do que lhe é proposto" (VIDAL, 2009, p. 29).
} 
Dentre os objetos produzidos e manipulados na/pela escola, aqueles relacionados à cultura escrita ocupam lugar central no conjunto de práticas escolares e indiciam a estreita relação entre a cultura escrita e a cultura escolar.

Muitas vezes, quando procuramos distinguir materiais e usos da escrita, buscando descobrir uma pedagogia da escrita, não devemos nos esquecer de que a própria escola se confunde com a escrita, atividade que ultrapassa o ensino deste objeto. Entre diferentes funções, a escrita pode ocupar um valor instrumental e a escola também pode se utilizar da escrita como forma de ocupação dos alunos, ou seja, como dispositivo disciplinar. Sendo assim precisamos ter em conta estas diversas funções cumpridas pela cultura escrita na escola, ao buscar distinguir seu lugar como componente do ensino e objeto a ser ensinado. (FRADE, 2008, p. 2, grifos nossos).

Assim, para delimitarmos ainda mais nosso foco de interesse, que recai sobre o processo de produção de textos por alunos recém-alfabetizados ou em processo de alfabetização, convocamos o campo da história da alfabetização ${ }^{5}$, que incide no "estudo de formas pretéritas de ensino/aprendizagem da tecnologia da escrita; [...] dos métodos para sua transmissão; dos materiais que estão em jogo na sua apropriação" (FRADE, 2011b, p. 180). Frade assinala que nos estudos empreendidos nessa área discute-se pouco sobre os objetos de escrita e sua relação com desdobramentos pedagógicos, que vão além de uma metodologia da alfabetização, mas que constituem as materialidades e a cultura escolar.

Assim, é certo que faríamos outras perguntas para estudar o analfabetismo ou a aprendizagem do ler e escrever se variássemos as instituições que transmitem os "rudimentos da escrita" e se olhássemos a demanda social para a aquisição da tecnologia que determinam práticas e usos relacionados à alfabetização, em determinado momento histórico. (FRADE, 2011b, p. 183).

Associando os estudos desses três campos de conhecimento - a história da cultura escrita, a cultura escolar e a história da alfabetização -, neste capítulo apresentaremos uma breve retomada histórica das relações sociais do ler-escrever e a instrução popular. Analisaremos os modos como variados suportes e instrumentos de escrita foram incorporados ao cotidiano das salas de aula da escola elementar e como sua inserção está intimamente relacionada com a organização dos modos/métodos vigentes bem como a constituição da

\footnotetext{
${ }^{5}$ Frade (2011b, p. 179) busca delimitar história da alfabetização como campo de estudo específico, justificando esse recorte por meio do argumento de que a aprendizagem da leitura e da escrita é marcada por rituais e conteúdos particulares e, dessa forma, deve ser abordada de maneira particular para distingui-la dos estudos sobre história da leitura e da escrita.
} 
própria instituição escolar: espaço, tempo e relação didática. Observaremos como razões técnicas e econômicas geralmente concorrem com justificativas pedagógicas no que tange às práticas escolares envolvendo a escrita. A retomada histórica, contextualizando práticas escolares em períodos de tempo diferentes do atual, pode nos propiciar uma visão mais crítica e reflexiva sobre as práticas da atualidade, especialmente no que concerne a mensurar possibilidades e restrições da inserção de novos instrumentos e suportes de escrita no interior da cultura escolar (RAZZINI, 2008).

De acordo com Soares:

A multiplicação histórica de métodos de alfabetização e as divergências em torno deles parecem ter sua explicação no fato de que a necessidade de ensinar a ler e a escrever, resultado da ampliação de novas possibilidades de acesso ao impresso e da democratização da educação escolar precedeu de muito o conhecimento de como se aprende a ler e a escrever, de modo que se pudesse definir com claros fundamentos e pressupostos como se deveria ensinar a ler e a escrever. Assim, os métodos tiveram sua origem muito mais em materiais para ensinar a ler e a escrever - inicialmente os abecedários, os silabários, durante largo tempo as cartilhas, mais recentemente os livros didáticos - que em fundamentos psicológicos e linguísticos da aprendizagem da modalidade escrita. (SOARES, 2016, p. 331, grifos nossos).

Faz-se necessário, desta maneira, compreender quais eram esses materiais voltados ao ensino da leitura e da escrita e como eles influenciaram a constituição das práticas de ensino da língua escrita.

\subsection{Retomada histórica do ensino da escrita na escola elementar da Europa Católica}

Em trabalho recente em que realiza importantes considerações acerca da história do ensino da leitura e da escrita na França e dos modos de letramento vigentes nos séculos passados, observamos a seguinte afirmação de Anne-Marie Chartier:

A oposição contemporânea iletrado versus alfabetizado tinha apagado uma categoria frequente até a metade do século XIX, a dos leitores "que sabiam apenas ler". (CHARTIER, A-M., 2016, p. 282). 
A compreensão acerca desse fenômeno fomenta questões sobre como o ensino da leitura e da escrita se desenvolveu na gênese da forma escolar e, por conseguinte, exige que retomemos as origens da instrução popular na Europa Católica, analisando as questões culturais e materiais envolvidas no ensino das primeiras letras.

Anne-Marie Chartier (2011) e Boto (2017) apontam o século XVI como o momento no qual se identificam as primeiras formas históricas de democratização das oportunidades escolares, impulsionadas por ocasião da Reforma ${ }^{6}$ e da Contrarreforma. Nesse momento, se observa uma notável mobilização da Igreja Protestante e, posteriormente, da Igreja Católica ${ }^{7}$ acerca da necessidade de ensinar ${ }^{8}$ a todas as crianças as doutrinas primordiais para sua salvação, para que "saibam ler literalmente as verdades de sua fé" (CHARTIER, A-M., 2011, p. 57). De acordo com Varela e Alvarez-Uria (1992), as tensões decorrentes do embate entre católicos e protestantes transformaram as crianças em alvos privilegiados de assimilação às respectivas ortodoxias.

O Concílio de Trento decreta que deverá existir um cônego em cada igreja catedralícia para instruir o baixo clero e os meninos pobres, e que devem se fundar escolas anexas a tais igrejas destinadas a formar jovens menores de $\mathbf{1 2}$ anos - filhos legítimos e preferentemente pobres a fim de que possam se converter em modelares pastores de almas. Novas ordens religiosas (Clérigos da Mãe de Deus, Doutrinos, Escolápios, Irmãos das Escolas Cristãs, etc.) encarregar-se-ão por sua parte do cuidado de jovens das classes populares e de instruí-los preferentemente na doutrina cristã e nos costumes virtuosos. (VARELA; ALVAREZ-URIA, 1992, p. 70, grifos nossos).

\footnotetext{
${ }^{6}$ Na retrospectiva, Anne-Marie Chartier (2011) aponta o livro "L'alphabétisation des français de Calvin à Jules Ferry", publicado em 1977 por Furet e Ozouf, como a obra responsável por desmistificar aspectos considerados como fundadores da escola laica e republicana, tirando dos iluministas e da Revolução Francesa os créditos pela aproximação da população com a cultura escrita e atribuindo-os, no caso da França, à Igreja Católica, frente à Reforma protestante, quando o ensino da leitura de textos sacros apresenta-se como importante ferramenta para promover a defesa da fé.

${ }^{7}$ Boto (2017, p. 99-100) assinala que é evidente que o impulso social em prol da leitura era mais acentuado nos países reformados, no entanto, mesmo entre católicos, revelava-se cada vez mais comum o fomento ao ensino da leitura de textos sacros restrita a alguns livros bíblicos, geralmente os Salmos.

${ }^{8}$ Encontramos tal afirmação também em Dominique Julia, com referência à realização do Concílio de Trento nos países católicos, que apregoava que "ser cristão não é mais, como nos séculos passados, somente pertencer a uma comunidade, manifestando-se como tal, mas ser capaz de proclamar pessoalmente as verdades da fé e ser instruído sobre as verdades de sua religião" (JULIA, 2001, p. 25). O autor ainda salienta que essa exigência gerou a aplicação de "exames de passagem", nos quais se verificava o nível de leitura e compreensão dos textos sacros pelos fiéis e, inclusive, implicava na rejeição daqueles que se mostravam incapazes de desempenhar tais habilidades.
} 
Algumas das novas ordens, dentre elas os Escolápios ${ }^{9}$ em Roma e os Irmãos das Escolas Cristãs na França, surgem unicamente com o propósito de instruir crianças pobres na doutrina cristã. Nesse contexto, Boto (2017, p. 99-100) assinala que houve o crescente fomento ao ensino da leitura inclusive nos países católicos, mas de uma leitura restrita a textos sacros. Ensinava-se a ler de uma maneira controlada, ou, nas palavras da autora: "Tratava-se de ensinar a ler, mas, mais do que isso, era fundamentalmente ensinar que nem tudo deveria ser lido". A fim de cumprir essa nova tarefa que Ihes fora atribuída, esses mestres utilizavam um método para o ensino da leitura muito similar ao que era empregado nos conventos: os alunos aprendiam a ler por meio da repetição das orações que conheciam melhor. Em outras palavras, para o ensino da leitura eram apresentados às crianças textos sacros conhecidos de cor, e unindo a declamação à imagem gráfica, se praticava a correspondência grafofonêmica.

Esse processo tem uma grande vantagem pedagógica: permite aos principiantes se exercitarem sozinhos, já que conhecem o texto oralmente. Saber bem a sua lição é ser capaz de coordenar, sem erro, nem hesitação, os olhos, o dedo e a voz. Cada recitação consolida a correspondência letra-som, e as crianças podem em seguida transferir esse saber para textos novos (mas do mesmo gênero, por exemplo, os 7 Salmos da Penitência que se cantam nos enterros). Limitados à leitura de livretos impressos, os alunos têm necessidade de uma aprendizagem especial para aprender a ler a escrita manuscrita de contas, contratos, títulos de propriedade. (CHARTIER, A-M., 2011, p. 62, grifos nossos).

O método descrito acima é adequado tanto aos propósitos do ensino da leitura pela Igreja - ou seja, instruir por meio de textos exclusivamente religiosos ${ }^{10}$ - quanto representa uma alternativa possível frente às ferramentas disponíveis: alguns poucos textos para a leitura e a falta de acesso a materiais para a prática da escrita ${ }^{11}$.

\footnotetext{
${ }^{9}$ Com relação ao ensino das classes populares no século XVI, Tanck de Estrada $(1988$, p. 56$)$ aponta o trabalho de ensino da leitura realizado pelos Padres das Escolas Pias, também chamados de Escolápios. Essa ordem religiosa dedicava-se, desde o século XVI, a ensinar as primeiras letras aos pobres por meio do método de grupos, constituindo, segundo a autora, o ensino nos moldes do que hoje é conhecido por "modo simultâneo" (um padre/professor/preceptor ensina a um grupo de alunos organizados por classes disponibilizando o mesmo material para apreciação coletiva, o que permite ensinar a todos ao mesmo tempo e não apenas a um indivíduo).

${ }^{10}$ Para uma análise sociológica minuciosa do papel da Igreja na educação das classes populares a partir do século XVI, ver Varela e Alvarez-Uria (1992).

${ }^{11}$ Dominique Julia (2001, p. 28) coaduna com essas afirmações e refletindo sobre o processo de profissionalização docente afirma que: "Em países católicos, pelo menos, a aprendizagem das verdades da salvação pôde ser feita por via puramente oral, através de um catecismo aprendido de cor, frequentemente mesmo em dialeto, posto que a
} 
É impossível ensinar a escrever às crianças: o papel é caro, as plumas de ganso muito difíceis de manipular. Em meios populares, a escrita é útil apenas aos filhos de comerciantes que devem saber manter um livro de conta. Para todos os outros, será "ler somente". (CHARTIER, A-M., 2011, p. 63).

Esse sistema de ensino da leitura por meio de textos conhecidos de memória ou decorados é muito eficiente no modelo de letramento em vigor na época, ou seja, nos modos como a sociedade se relacionava com textos escritos. Ao longo dos séculos XVI e XVII, as sociedades na Europa experimentam uma relação com a escrita denominada "letramento restrito"$^{12}$, que remete a um contexto no qual textos manuscritos ou impressos ${ }^{13}$ atingem certa circulação social, mas não estão efetivamente imbricados na vida das pessoas: a escrita coexiste com as culturas orais sem penetrá-las verdadeiramente. Dada a quantidade extremamente restrita de textos, a leitura tem um caráter intensivo, ou seja, poucos textos são conhecidos e, geralmente, eles são sabidos de cor. Nessa relação leitor-texto, “ler é interiorizar exaustivamente e definitivamente o texto do outro" (CHARTIER, A-M., 2011, p. 62).

No entanto, com o alargamento das práticas sociais de leitura ${ }^{14}$ que paulatinamente se instaura ao longo dos séculos XVIII e XIX, os sujeitos sentem a necessidade de ler outros textos

Igreja, diferentemente dos Estados, privilegia a língua vernácula local em detrimento da língua imposta pelo poder central".

${ }^{12}$ Para além do par oralidade-letramento, Jack Goody e lan Watt, na obra "The Consequences of Literacy" (1963, apud CHARTIER, A-M., 2011), apresentam o par "letramento restrito" e "letramento generalizado" como dois grandes regimes de uso. O letramento restrito seria um modelo no qual a escrita coexiste com a cultura oral sem efetivamente penetrá-la. Já no letramento generalizado, a "oralidade das trocas" é penetrada pela escrita, sempre de maneira implícita. Anne-Marie Chartier aponta que cada modelo de letramento evoca práticas sociais de leitura específicas. Os séculos XVI ao XVIII, quando se desenvolveu o letramento restrito, resguardam práticas de leitura intensiva: lenta, atenta e exaustiva de um corpus fechado. Já no período após a Revolução Francesa, a prática de leitura se torna mais extensiva, ou seja, as pessoas se engajam em práticas mais fluidas, com informações que podem ser facilmente esquecidas, perecíveis, tendo acesso a um conjunto muito maior de textos, como jornais, romances e novelas.

${ }^{13}$ Vale ressaltar a advertência de Roger Chartier $(1999$, p. 9) sobre o mito que se instaurou acerca de um movimento de ruptura entre cópias manuscritas e impressas: "Na realidade, o escrito copiado à mão sobreviveu por muito tempo à invenção de Gutemberg, até o século XVIII e mesmo o XIX".

${ }^{14}$ Neste parágrafo, fazemos alusão a uma transformação longa e complexa que não poderemos esmiuçar neste trabalho. Em linhas gerais, trata-se da transição de um modelo de letramento restrito para o letramento generalizado, conforme proposto por Jack Goody e lan Watt (apud CHARTIER, A-M., 2011). Reinhard Wittmann (1998) nomeia essa transição como "a revolução da leitura", movimento impulsionado pela burguesia cultural, composta por eruditos que viviam às margens da nobreza, que no início do século XVIII se encontraram suspensos das posições sociais relevantes e acabaram por constituir um potencial de revolta que questionava, especialmente, o monopólio de informação e interpretação das autoridades eclesiásticas e estatais e operavam em prol do desenvolvimento de novas estruturas de comunicação. Assim, rejeita-se a informação eclesiástica e busca-se a 
e, ainda, lê-los de outras maneiras: se antes havia uma leitura intensiva de poucos textos conhecidos de cor, transita-se para uma leitura extensiva ${ }^{15}$ de textos desconhecidos, que poderiam ter seu conteúdo esquecido a qualquer tempo. Os meios materiais de produção e circulação se modificam e novas relações entre leitor e texto se desenvolvem.

Quando, no século XVIII, as impressoras mecânicas asseguraram um sucesso crescente para os jornais e revistas e para os romances, o frenesi que se apoderou dos leitores (e das leitoras) provocou incredulidade e escândalo. Ler não era mais reler, em conjunto, um corpus limitado e reconhecido de textos considerados de pouca utilidade: era tratar individualmente múltiplas informações, tomar rapidamente conhecimento das notícias do mundo, ou mergulhar silenciosamente "em um outro mundo" de histórias desconhecidas, efêmeras, reais ou inventadas. (CHARTIER, A-M., 2016, p. 290).

Nesse contexto, os mestres responsáveis pelo ensino da leitura se deparam com um problema: como fixar na memória dos alunos o sistema de escrita alfabético, que lhes permitirá ler novos textos? De acordo com Anne-Marie Chartier a investida metodológica nesse período de transição entre um modelo de leitura intensivo para um modelo de leitura extensivo era a técnica da soletração, que surge como uma alternativa decorrente da dissociação entre leitura e escrita, funcionando como um "substituto oral do gesto gráfico". No entanto, esse método não surtiu os efeitos desejados, conforme assinala a autora:

Se podia "funcionar" sobre textos conhecidos de cor, essa técnica [de soletração] se torna contraproducente quando se exerce sem esse suporte, entre os anos 1750 e 1850, quando a leitura silenciosa, rápida, difunde-se ao mesmo tempo que a leitura das novelas, dos jornais, das gazetas. Os preceptores são os primeiros a querer preparar seus alunos para a leitura "generalizada": param de fazer ler as orações e se lançam imediatamente com o seu aluno no estudo das sílabas, depois palavras com uma, duas, três sílabas. [...] Quando a criança domina todas as sílabas sem significado, supõe-se que ela possa ler "qualquer texto". (CHARTIER, A-M., 2011, p. 63).

conquista e a afirmação da identidade individual, sobretudo na esfera espiritual. Essa, que seria conhecida como a "identidade burguesa", ansiava pela constante comunicação para a ampliação de seu limitado mundo empírico. 0 meio que supriu essa necessidade foi a palavra impressa: cultura escrita e literatura tornaram-se campo de treinamento do autoentendimento (autoconhecimento). Com isso, o livro e a leitura ganharam um novo valor na consciência pública. Trata-se do chamado "aburguesamento da sociedade, da cultura e da literatura" (WITTMAN, 1998, p. 138).

${ }^{15}$ De acordo com Anne-Marie Chartier (2016, p. 292), a relação leitor-texto extensiva pode ser denominada como "leitura como recepção de textos desconhecidos" e consiste em selecionar as informações que permitirão a construção de uma representação global do texto. Esse modelo de leitura é sucessor da "leitura intensiva de textos conhecidos de cor" e coexiste, na atualidade, com um terceiro modelo, o de "leitura funcional-interativa", que começa a ser observado quando os suportes de leitura se transformam em máquinas. A circulação dos textos em máquinas (smartphones, computadores) permite interação imediata entre leitor-texto-autor. 
É nesse contexto que são apontados os primeiros sinais de fracasso no ensino da leitura, que seriam mitigados, de acordo com Anne-Marie Chartier (2011, p. 64), apenas por volta de 1850, quando o barateamento do papel e o advento da pena metálica tornam possível a execução de exercícios de escrita no processo de ensino e aprendizagem das primeiras letras, iniciando um processo de incremento nos resultados escolares.

No entanto, a inserção da escrita na escola elementar não ocorreu de maneira simples, tampouco rápida, tendo sido um processo que perdurou ao menos um século para sua ampla popularização. ${ }^{16}$ De acordo com Hébrard (2001, p. 117), adotar o ensino da escrita nas escolas dependia da conquista de três pontos basilares: i) mestres que se dispusessem a ensinar a grafia das letras; ii) uma orientação pedagógica que permitisse conduzir as aprendizagens - como a gramática escolar ${ }^{17}$ dedicada à ortografia e os impressos contendo métodos associando leitura e escrita -; e, por fim, iii) instrumentos diversos que permitissem a escolarização dessa aprendizagem.

Partindo dos pontos elencados, temos na figura do mestre a primeira questão a ser resolvida: até o século XVIII, o ensino da escrita restringia-se aos mestres escritores ${ }^{18}$. De acordo com Vidal e Gvirtz (1998) e Hébrard (2001), ainda no século XVIII, na França, o grupo fundado por Jean-Baptiste de La Salle ${ }^{19}$, os Irmãos das Escolas Cristãs ${ }^{20}$, propõe se engajar em um

\footnotetext{
${ }^{16}$ Essa estimativa de período de tempo é calculada a partir das primeiras investidas de La Salle, por volta de 1710 (cf. BARRA, 2013), até a ampla popularização do papel e da pena metálica, em 1840 (cf. CHARTIER, A-M., 2007, 2011, 2016).

${ }^{17}$ Cf. Chervel (1977).

${ }^{18}$ Vincent, Lahire e Thin (2001, p. 13) observam que "durante muito tempo, nas cidades, os 'mestres-escritores' resistiram à intrusão dos mestres de escola". O termo "mestres calígrafos" é utilizado em Boto (2017, p. 253).

${ }^{19}$ De acordo com a caracterização feita por Barra (2013), Jean-Baptiste de La Salle nasceu em Reims, em 30 de abril de 1651, e morreu em 7 de abril de 1719. Ele fundou o Instituto dos Irmãos das Escolas Cristãs e defendia a instrução gratuita para crianças pobres, órfãos e outros pobres que precisavam trabalhar e não podiam estudar e teve conflitos com as corporações de mestres escrivães porque propunha a vulgarização da escrita. Escreveu a obra "Conduta das escolas cristãs", publicada em 1720 e dividida em duas partes: "Os exercícios que se fazem nas escolas cristãs e a maneira como se devem fazer" e "Os meios para estabelecer e manter a boa ordem".

${ }^{20}$ Vincent, Lahire e Thin (2001, p. 12) apontam como uma "novidade radical" as escolas urbanas desenvolvidas ainda no século XVII pelos Irmãos das Escolas Cristãs. Esse grupo, fundado por Jean-Baptiste de La Salle em 1680 em um movimento de inovação, promoveu a organização do ensino simultâneo, ou seja, um professor ensina o mesmo conteúdo para vários alunos, rompendo com a lógica da relação "artesão-aprendiz". Os Irmãos não eram padres, mas tinham como premissa os preceitos cristãos; eles eram professores pobres que davam aulas para crianças pobres. Esse mesmo grupo desempenhará no século XVIII um papel fundamental no ensino da escrita na escola elementar (HÉBRARD, 2001).
} 
processo de simplificação das técnicas gráficas de escrita, com o intuito de distinguir a escrita rudimentar da escrita caligráfica ornamental. Esse processo faz parte de um movimento que consiste no deslocamento de quem poderia ensinar a escrever: do ensino realizado exclusivamente pelo mestre-calígrafo ao seu discípulo (como arte de ofício) para o ensino massificado da escrita rudimentar (escrita como uma linguagem da era moderna, difundida massivamente). Tal movimento consolida-se apenas no começo do século $\mathrm{XIX}^{21}$, quando a técnica de escrita complexa se libera definitivamente das corporações especializadas dos mestres-calígrafos. Outra grande inovação atribuída ao grupo dos Irmãos das Escolas Cristãs foi a criação do quadro-negro como superfície coletiva de leitura e escrita que permitia tanto o ensino concomitante da leitura e da escrita quanto ao mestre dirigir seu ensino a um grupo grande de alunos, ou seja, que o ensino fosse organizado de modo simultâneo ${ }^{22}$ (BARRA, 2013; VINCENT; LAHIRE; THIN, 2001).

É importante salientar que os novos modos sociais de circulação de textos escritos tornavam a habilidade da escrita cada vez mais desejável, impulsionando o número de pessoas que buscavam o acesso a ela. ${ }^{23}$ Nesse contexto, a iniciativa dos Irmãos das Escolas Cristãs assume duas funções: uma especialmente interessante à Igreja e outra conveniente à burguesia. No que toca à Igreja, o ensino da escrita rudimentar é parte de estratégia dos Irmãos das Escolas Cristãs para atrair crianças dos meios populares para o catecismo ${ }^{24}$, ou seja, é um modo da Igreja Católica atrair pessoas influenciadas pela propaganda reformada ou já descristianizadas. Já na perspectiva burguesa, o ensino dos rudimentos da escrita à população funcionaria como uma importante ferramenta para enfraquecer as antigas culturas camponesas, calcadas na oralidade, e abrir espaço para a modernidade, especialmente por:

\footnotetext{
${ }^{21}$ É preciso ainda observar com Hébrard (2001, p. 117) que "mesmo que a França tenha conhecido, desde o século XVIII, uma escola centrada no ler-escrever e no contar, foi somente a partir das grandes reformas escolares da primeira metade do século XIX que esse novo trivium se torna o instrumento essencial de uma educação do povo urbano ou rural pela escola".

${ }^{22}$ Analisaremos de modo minucioso o advento do quadro-negro na seção 1.3.

${ }^{23}$ Hébrard (2001, p. 116) menciona que "Aprender a escrever para fazer contas e para redigir algumas cartas comerciais exigidas desde o século XVII pela boa direção de uma loja ou de uma barraca não era uma coisa fácil”.

${ }^{24}$ Anne-Marie Chartier (2016, p. 283) assinala que a alfabetização "tinha podido crescer sem escolas e que era, em todos os lugares, ligada à catequese cristã das crianças".
} 
Depois das turbulências da Revolução, a preocupação de uma alfabetização mais completa difundida pelas ideias liberais e filantrópicas começa a visar as populações dos campos ainda imersas em uma cultura que privilegiava a oralidade. Agora não é apenas a formação cristã que está em jogo, porque trata-se de subtrair as populações do campo dos rumores, temores e paixões que são as sementeiras das revoltas camponesas. Os notáveis e as elites que atravessaram os tempos convulsionados da Revolução têm ainda na memória a lembrança dessas revoltas. Instruindo, a escrita pode erradicar as antigas culturas camponesas e abrir o espaço rural francês para a modernidade e a paz social. (HÉBRARD, 2001, p. 116, grifos nossos).

Abordando esse mesmo contexto, Boto assinala:

$\mathrm{Na}$ verdade, as escolas lassalianas reforçavam bastante a técnica da escrita, quando comparadas com a primazia da leitura existente na época. A escrita começava a ser necessária para efetivar algumas habilidades do mundo urbano de caráter mercantil. [...] A lógica do fortalecimento das habilidades básicas do ler, escrever e contar conjugava requisitos de uma cultura clerical - que solicitava do fiel a leitura - com a urgência da cultura urbana, que precisava da escrita; e, para a vida mercantil, pedia também o cálculo aritmético. (BOTO, 2017, p. 264, grifos nossos).

A preocupação com uma formação cristã associada à necessidade de reorganizar a estrutura social impulsiona o ensino da escrita. Nesse contexto, a simples "alfabetização cristã", o "somente ler" ${ }^{25}$, já não é suficiente para atender as demandas da sociedade burguesa. No entanto, a simplificação da técnica de escrita empreendida pelos Irmãos das Escolas Cristãs envolve, para além da figura do mestre apto para seu ensino, a inserção de instrumentos específicos que possibilitem sua prática. Tendo como objetivo o ensino das classes populares, mesmo no final do século XVIII seria inviável contar com os instrumentos voltados à caligrafia ornamental - como pena, tinteiros e papel -, que exigem recursos tão dispendiosos e que demandam, inclusive, adequações no mobiliário dos ambientes de ensino, por exigir cadeiras e mesas específicas para seu exercício (BARRA, 2013, p. 122). Assim, tornam-se populares a utilização do quadro-negro e de pequenas lousas de ardósia individuais, os gizes e as caixas de areia para os aprendizes iniciantes; os cadernos eram reservados apenas para os que já detinham mais experiência no traçado das letras.

As ardósias e os gizes permitem aos mais jovens treinar para fazer e o " $\mathrm{i}$ " e o " $\mathrm{o}$ ", os maiores têm cadernos de papel de celulose, baratos, sobre os quais escrevem com plumas metálicas que não se desgastam. Copiam linhas de letras e de sílabas, que memorizam dessa maneira, mas em escrita cursiva. Consequentemente, a escrita

\footnotetext{
${ }^{25}$ A alfabetização do "somente ler" como "alfabetização cristã" foi assim definida por Hébrard (2001).
} 
cursiva aparece nos manuais de leitura, ao lado das letras de imprensa. (CHATIER, 2011, p. 64).

Desse modo, o ensino da escrita é introduzido no processo de instrução popular. Todas essas mudanças descritas acima ganharam efetiva materialização no contexto escolar na medida em que a escola renovava sua roupagem, assumindo um papel institucional. Para marcar esse novo espaço, o espaço escolar, são desenvolvidas práticas cada vez mais distanciadas da esfera familiar ou religiosa. Assim, ao final do século XVIII e ao longo do século XIX, observa-se a consolidação da forma escolar na Europa por meio da profissionalização do trabalho de ensino, da dissociação do tempo escolar do tempo comunal, do crescimento de construções de espaços específicos voltados à prática educativa, da produção das disciplinas escolares e, o que nos interessa especialmente, da proliferação de materiais escolares.

A seguir, abordaremos o processo de constituição do ensino das primeiras letras na América Latina, de modo a ampliar o panorama histórico. Por fim, analisaremos de maneira pormenorizada as influências dos materiais da cultura escrita e a constituição da escola moderna, com foco especial no movimento de inovações e permanências dos materiais e dos métodos ao longo do século XIX (VIDAL; GVIRTZ, 1998).

\section{2. $O$ ensino da leitura e da escrita na América Latina e no Brasil}

No Brasil $^{26}$ e em outros países que sofreram colonização ibérica ${ }^{27}$, os processos relacionados ao ensino da leitura e escrita das camadas populares assumem um caráter bastante complexo em virtude dos massacres promovidos pelos expugnadores europeus, especialmente no que concerne à dominação cultural. Desde os primeiros contatos entre europeus e indígenas, a língua dos povos nativos configurou um problema a ser resolvido pelos

\footnotetext{
${ }^{26}$ Para uma compreensão global da história do ensino da leitura no Brasil, seria necessário abordarmos o trabalho empreendido pelos jesuítas sobre as línguas indígenas, para que elas fossem "desenselvajadas" pelo duplo movimento de sua escrita e de sua descrição gramatical, até culminar no processo de ensino da língua (cf. DAHER, 2012).

${ }^{27}$ Vidal e Gvirtz (1998) realizam uma análise histórica comparativa entre os processos desenvolvidos no Brasil e na Argentina.
} 
missionários jesuítas que chegam ao Brasil com as autoridades administrativas. É por meio da palavra que esses missionários trabalham na conversão das almas que vieram conquistar, por meio do exercício do "magistério e o ministério da Igreja" (HANSEN, 2001, p. 20). De acordo com Daher (2012), para atingir seus objetivos, os missionários reduzem as línguas que ouvem em uma escrita e uma gramática compatíveis com a estrutura do latim, para que assim possam ensiná-las em seus colégios. Uma grande variedade de formas textuais com fins catequéticos foi produzida por missionários em língua indígena, como as traduções do catecismo romano, das orações, dos sermões, das homilias, entre outros, bem como a escrita de textos em língua autóctone, como biografias de indígenas piedosos, gramáticas e vocabulários (DAHER, 1998, p. 33). Desse conjunto, duas formas textuais são especialmente interessantes para o ensino da leitura no Brasil Colonial: as gramáticas das línguas indígenas e os catecismos (ou doutrinas). Associadas, conformam o principal instrumento do projeto evangélico desenvolvido no Brasil ao longo dos séculos XVI e XVII.

Nada de tão surpreendente julgarmos que leitura e pregação andam juntas. Tanto a gramática - produzida, a princípio, por missionários para missionários - quanto a cartilha proporcionam a passagem da língua indígena para o escrito e, a partir daí, a fixação das formas sintáticas, garantia da possibilidade de perpetuação da tradição religiosa. Gramática e catecismo ou cartilha e catecismo até mesmo aparecem frequentemente lado a lado, impressos no mesmo livrinho, como é o caso da Cartilla y dotrina christiana... en la lengua chuchona, de frei Roldán, editada para que "sirva de Cartilla y doctrina y dialogo". (DAHER, 1998, p. 34).

De tiragem bastante reduzida, os catecismos, e especialmente as gramáticas, eram destinados aos usos dos padres na tarefa missionária que conjuga a instrução religiosa com a instrução das regras e preceitos da língua. De acordo com a autora, publicam em 1618, às custas dos padres do Brasil e organizado pelo padre Antônio de Araújo, o livro "Catecismo da língua brasílica", constituído por duas obras que circulavam até então em forma manuscrita, o "Diálogo da fé", composta por José de Anchieta, e a "Doutrina cristã", traduzida por ele.

A utilização desses livros de catequese não diminui a figura do missionário como mediador: as publicações atuam como instrumentos capazes de aproximar os missionários da língua local e assim garantir o sucesso da missão catequética. De acordo com Daher (1998), nos prólogos dos catecismos em geral não se recomenda o manuseio direto do livro por parte do 
índio catecúmeno, da mesma forma que não se recomenda unicamente a audição da instrução para a tradicional memorização do conteúdo das doutrinas. O que se ressalta é o missionário reconhecer nesses impressos uma fonte vocabular da língua indígena para que fosse possível estabelecer uma comunicação satisfatória com vistas à catequese dos nativos, conforme assinala Nóbrega:

Não deixando de advertir aos que desejão aprender a lingoa, pera com Ella acodirem ao fim de sua vocação; que todos estes Dialogos, instruçoens \& mais cousas annexas Ihes podem administrar huma materia de lingoa mais ampla pera lhes não faltar (andando nelles bem vistos) a necessária pera o bem espiritual dos Indios. (NÓBREGA ${ }^{28}$, apud DAHER, 1998, p. 37).

As operações escriturárias de gramaticalização, como a tradução e a metrificação de textos - por exemplo, a tradução de orações e poemas em Tupi -, tornam possível que o índio catecúmeno pronuncie por si e em sua própria língua as doutrinas cristãs, realizando modificações nos modos de organizar sua memória e de formar sua consciência. Assim, leva-se a cabo a missão evangelizadora atribuída aos missionários, doutrinando e civilizando os nativos, como constata o testemunho de Anchieta:

[...] quase todos [os meninos] vêm duas vezes por dia à escola, sobretudo de manhã; pois de tarde todos se dão à caça ou à pesca para se darem sustento; se não trabalham não comem. Mas o principal cuidado que temos deles está em lhes declararmos os rudimentos da fé, sem descuidar o ensino das letras; estimam-no tanto que, se não fosse esta atração, talvez não os pudéssemos levar a mais nada [...] (ANCHIETA, 1984, apud DAHER, 1998, p. 42, grifos nossos).

O exercício da Companhia de Jesus ${ }^{29}$ perdura até o ano de 1759 , quando ocorre a expulsão dos jesuítas como parte das Reformas llustradas promovidas pela Coroa Portuguesa. Apesar de muitos historiadores utilizarem esse período para marcar uma espécie de cisma na história da educação brasileira, Villalta (2002) assinala que as diferenças entre o ensino jesuítico

\footnotetext{
${ }^{28}$ NÓBREGA, Manuel da. Diálogo sobre a conversão do gentio. In: LEITE, Serafim. Cartas dos primeiros jesuítas do Brasil. São Paulo: Comissão do IV Centenário da Cidade de São Paulo, 1954. v. II, p. 319.

${ }^{29}$ A atuação da Companhia de Jesus foi extremamente ampla e complexa, tanto na Europa quanto nas colônias. Aqui, nos limitamos a descrever a atuação desse grupo no ensino das primeiras letras para os nativos ao longo dos séculos XVI e XVII. Os estudos posteriores eram norteados pelo Ratio Studiorum, importante documento inaciano. Estudos pormenorizados da atuação desse grupo podem ser encontrados em Daher (2001, 2012), Hansen (2001) e Boto (2017).
} 
e o ensino das reformas educacionais pombalinas não representam mudanças tão drásticas na educação brasileira. Mudanças mais substanciais aparecem nos anos 1820 e 1830, como assinala Hilsdorf (2001, p. 70), após o Período Pombalino, quando podem ser observados nos documentos redigidos pelos ilustrados e liberais brasileiros traços indicativos de um movimento racionalista em direção à educação das classes populares, com a característica de atribuir sua responsabilidade ao Estado e não apenas à Igreja.

Apesar de não dispormos de dados que abordem de maneira mais minuciosa os modos como se efetivaram a relação didática e os materiais utilizados para o ensino das primeiras letras pelos inacianos ${ }^{30}$ no período descrito acima, o vasto estudo desenvolvido pela historiadora Dorothy Tanck de Estrada acerca do ensino da leitura e da escrita no território da Nova Espanha (atual México), fornece subsídios para que façamos reflexões mais aprofundadas sobre a profusão do ensino da leitura nas colônias latino-americanas. O modo como se desenvolvia o ensino das primeiras letras nas diferentes colônias guarda uma série de semelhanças, tanto em relação ao modo como a cultura escrita ganhava paulatinamente seu espaço na vida social como também nos artefatos utilizados para o ensino da leitura e da escrita (VIDAL; GVIRTZ, 1998).

De fato, assim como na Europa, ao longo dos séculos XVI e XVII observava-se no território da Nova Espanha o fomento ao ensino da leitura, principalmente por essa habilidade estar diretamente implicada na "aprendizagem do catecismo e na formação moral dos cristãos" (TANCK DE ESTRADA, 1988, p. 49). Iniciando sua análise a partir dos materiais disponíveis para o ensino da leitura, Tanck de Estrada aponta a ampla utilização, tanto na Espanha quanto nas colônias, de uma "cartilla" intitulada "Arte para enseñar a leer perfectamente y en muy breve tiempo, compuesto según la vía o perfecta orden del deletrear". O material apresentava, nas primeiras páginas, o alfabeto (maiúsculo e minúsculo) e, a seguir, as sílabas organizadas de acordo com sua complexidade e de maneira isolada, sem compor nenhuma palavra. Após as

\footnotetext{
${ }^{30} \mathrm{O}$ termo remete a Inácio de Loyola, fundador da Companhia de Jesus.
} 
quatro primeiras páginas, o restante da cartilha traz orações e pontos da doutrina cristã ${ }^{31}$. De acordo com a autora:

Incluir na cartilha orações e conceitos religiosos como textos para leitura corroborava com a ideia de que o objetivo primordial da aprendizagem da leitura era auxiliar na formação religiosa. (TANCK DE ESTRADA, 1988, p. 53, tradução nossa). ${ }^{32}$

Assim, para o ensino da leitura, as cartilhas associavam a um primeiro exercício de soletração de letras e sílabas a recitação de textos religiosos conhecidos de memória, relacionando o recitado ao escrito. Quando a criança já dominava a soletração da cartilha, passava-se a um segundo livro, chamado "Catão", no qual se apresentava um conteúdo um pouco mais variado, contendo textos religiosos, como o "Evangelho", e outros textos voltados à descrição dos deveres com o rei e com a Igreja (TANCK DE ESTRADA, 1988, p. 54).

Os estudos desenvolvidos por Villela (2007), Vidal e Gvirtz (1998) e Tanck de Estrada $(1988,1990)$ assinalam que o ensino no Período Colonial é muito marcado pela multiplicidade de formas e locais de ensinar e aprender a ler. Apesar da dispersão de métodos e normas, o que se pode afirmar de modo geral é que nesse período "qualquer que fosse o texto ou o método, os que aprendiam a ler estavam em grupos separados dos que aprendiam a escrever" (TANCK DE ESTRADA, 1988, p. 64, tradução nossa) $)^{33}$.

Por que se separavam o ensino da leitura e o da escrita? A nosso parecer se devia mais a razões "técnicas" e "econômicas" que a razões "pedagógicas". O papel importado era escasso e caro, a tinta preta poderia manchar e arruinar a roupa, o manejo da pena requeria certa destreza e habilidade manual. Daí a prática de reservar a escrita para os que já sabiam ler. Nem todas as crianças continuariam seus estudos depois de aprender a ler. (TANCK DE ESTRADA, 1988, p. 83, tradução nossa). ${ }^{34}$

\footnotetext{
${ }^{31}$ Tal foi a extensão do alcance de uso dessas cartilhas que, ao final do século XVIII, quando começam a tecer críticas em relação ao método da soletração, os "intelectuais" espanhóis costumam tratar esse material sob a denominação de "cartilla común" (TANCK DE ESTRADA, 1988, p. 55).

32 "Incluir en la cartilla oraciones y conceptos religiosos como textos para la lectura concordaba con la idea de que el objetivo primordial para aprender a leer era ayudar en la formación religiosa" (TANCK DE ESTRADA, 1988, p. 53).

33 "En varias escuelas, sin embargo, se empezaban a usar otros libros elementales, como el silabario y nuevos catones, además de emplear el silabeo como técnica de aprendizaje. Fuera el que fuese el texto o el método, los que aprendían a leer estaban en grupos separados de los que aprendían a escribir" (TANCK DE ESTRADA, 1988, p. 64).

34 "¿Por qué se separaban la enseñanza de la lectura y la de la escritura? A nuestro parecer se debía más a razones "técnicas" y "económicas" que a razones "pedagógicas". El papel importado era escaso y caro; la tinta negra podría manchar y arruinar la ropa; el manejo de la pluma requería cierta destreza y habilidad manual. De ahí, la práctica
} 
Assim como na Europa, o exercício da escrita até fins do século XVIII é bastante restrito e majoritariamente ainda se encontra nas mãos de escribas (corporações de ofício). No que tange à questão material, abordando de maneira mais específica o caso do território da Nova Espanha, o acesso ao papel feito de polpa de madeira, ao papel riscado por litografia, à pena metálica, à lousa e ao lápis de ardósia ${ }^{35}$ bem como o lápis de grafite ocorre apenas depois da independência mexicana (TANCK DE ESTRADA, 1988, p. 77). A limitação do ensino da escrita era resultado, para além da questão dos custos envolvidos, do considerável tempo de trabalho despendido pelo professor, pois se fazia necessário uma série de preparativos relacionados ao material, como aparar cada pena a ser utilizada pelo aprendiz e, ainda, traçar linhas no papel liso, de modo a facilitar a prática de escrita dos alunos principiantes.

Além de aparar cuidadosamente cada pena que será utilizada, o professor deveria preparar o papel. As folhas de trapo eram lisas, sem linhas. Um aluno principiante na arte de escrever necessitava de linhas paralelas para guiar o olho e a mão e assim colocar as letras e palavras em linhas horizontais, linha após linha. (TANCK DE ESTRADA, 1988, p. 80, tradução nossa). ${ }^{36}$

O grupo que não prosseguia os estudos após a aprendizagem da leitura era formado por homens pobres que precisavam trabalhar e mulheres ${ }^{37}$. No entanto, para os poucos que podiam seguir nas classes de escrita, o processo de ensino apresentava uma progressão bastante relacionada ao uso dos instrumentos: primeiro, o aluno utilizava um graveto ou o próprio dedo para contornar as letras maiúsculas e minúsculas já impressas nos "modelos ${ }^{38 "}$ ou nas letras

de reservar la escritura para los que ya sabían leer. No todos los niños continuaron sus estudios después de haber aprendido a ler" (TANCK DE ESTRADA, 1988, p. 83).

35 Traduzimos o termo "pizarrines" por "lápis de ardósia" apoiados no estudo de Barra (2013) e também pela tradução do termo "pizarra", que no espanhol moderno significa tanto quadro-negro escolar quanto dá nome à pedra ardósia.

36 “Además de tajar cuidadosamente cada pluma que se iba a utilizar, el maestro tenía que preparar el papel. Las hojas de trapo eran lisas, sin rayas. Un alumno principiante en el arte de escribir necesitaba líneas paralelas para guiar el ojo y la mano y así colocar las letras y palabras en líneas horizontales, renglón tras renglón" (TANCK DE ESTRADA, 1988, p. 80).

${ }^{37}$ Em relação às mulheres, Tanck de Estrada $(1988$, p. 84) salienta que as famílias costumavam privar as filhas do aprendizado da escrita como modo de regular suas correspondências amorosas.

${ }^{38}$ Ainda no final do século XVIII, registra-se a publicação de "muestras" ou "modelos" de escrita na Espanha. Os "modelos" consistiam em jogos de folhas impressas com letras maiúsculas e minúsculas, palavras e frases escritas 
grafadas pelo próprio mestre na "tela pintada de negro", a seguir, realizavam o mesmo procedimento utilizando as plumas sem molhá-las na tinta, observando sempre a correta postura corporal. Com esses exercícios, praticava-se a forma correta das letras sem utilizar papel. Posteriormente, as tarefas envolviam o uso de tinta e para desenvolvê-las os alunos sempre contavam com papel pautado pelo professor. Considerava-se que o aluno alcançava o sucesso na aprendizagem da escrita quando conseguia escrever "solto" ou seja, quando não necessitava mais de linhas ou outras marcações realizadas na folha pelo mestre. De acordo com Tanck de Estrada, os textos que resultavam dos exercícios de escrita eram, basicamente, cópias: "Geralmente se copiavam lemas que se referiam às regras da escrita, a ortografia, as máximas da religião, a moral ou a urbanidade" (TANCK DE ESTRADA, 1988, p. 85, tradução nossa) ${ }^{39}$.

Em suma, observamos que os movimentos em prol do ensino da leitura desenvolvidos ao longo dos séculos XVI, XVII e no início do XVIII na América Latina estavam intimamente atrelados ao movimento de catequização das populações locais, e que os modos de se relacionar com o material escrito assemelhavam-se bastante com o que ocorria na Europa: uma relação restrita, sempre circunscrita a textos sacros. A seguir, analisaremos como as transformações no cenário sociopolítico da América Latina vão alterar as práticas de leitura e suas consequências no ensino das primeiras letras.

\subsubsection{O processo de emancipação política das colônias e os modos de ler e escrever}

As práticas envolvendo o ensino da leitura e da escrita descritas acima caracterizam o Período Colonial do território da Nova Espanha e, por conseguinte, nos permitem traçar alguns paralelos com o que ocorreu em outros países latino-americanos (VIDAL; GVIRTZ, 1998). Abordando de maneira mais específica as iniciativas em prol da democratização das oportunidades escolares na América Latina, é no século XVIII que se observa um momento de

em um determinado estilo de caligrafia (TANCK DE ESTRADA, 1988). A difusão desse material assinala uma centralização do ensino da escrita na caligrafia, nas questões de forma e estilo gráfico.

39 "Generalmente se copiaban lemas que se referían a las reglas de la escritura, la ortografia, las máximas de la religión, la moral o la urbanidad" (TANCK DE ESTRADA, 1988, p. 85). 
renovação da atividade educativa, que vai assumir, pouco a pouco, objetivos mais utilitários e menos religiosos (VILLELA, 2007, p. 97).

Esse período é subsequente a uma forte investida das metrópoles em estratégias para reforçar sua dominação sobre as colônias. No Novo México, ao final dos setecentos e início dos oitocentos, se observavam de maneira concomitante as incursões de reforço da dominação europeia por meio das escolas elementares concorrendo com a emancipação política das colônias, que ganha cada vez mais relevância nas ruas. É nesse contexto efervescente que surgem os primeiros periódicos e há um aumento considerável da circulação de textos de índole profana. Esse período é marcado por uma gradual transformação nos modos como os sujeitos se relacionavam com a cultura escrita, transitando de uma prática de leitura e escrita restritas ao mundo da religião e do comércio para práticas de leitura e escrita sobre assuntos diversificados - literatura, notícias, arte -, que estabeleciam uma relação dialógica com o momento político de emancipação, tornando as atividades leitoras mais interativas e críticas.

As publicações de índole profana excitaram a curiosidade dos habitantes, que esperavam a chegada dos periódicos e trocavam ideias sobre as notícias. Se desenvolvia o que se pode chamar de "alfabetização libertadora" ${ }^{40}$, ou seja, o exercício mais ativo e independente da leitura. (TANCK DE ESTRADA, 1988, p. 87, tradução nossa). ${ }^{41}$

Havia também orientações pedagógicas publicadas na década de 1780 acerca da organização do ensino, tendo como foco a readequação da relação mestre-aluno, que antes ocorria majoritariamente por meio do ensino individual - no qual o mestre auxiliava aluno por aluno e adequava as tarefas de acordo com cada um deles - e passou a ser pelo ensino de modo simultâneo, ou mútuo, que prevê o agrupamento de alunos em níveis semelhantes. Algumas das publicações mencionadas acima sugeriam redimensionar a relação mestre-aluno aos

\footnotetext{
${ }^{40}$ A autora se refere à proposta do historiador Lawrence Cremin (1970), que utiliza o termo "alfabetização inerte", quando se detém à mínima competência técnica voltada aos usos práticos, em oposição à "alfabetização libertadora", que denomina aprender a competência da leitura e da escrita e desenvolvê-la não só como uma habilidade técnica de um indivíduo, mas como uma habilidade técnica em interação com um ambiente literário.

41 "Las publicaciones de índole profana excitaron la curiosidad de los habitantes, que esperaban la llegada de los periódicos e intercambiaban ideas acerca de las noticias. Se desarrollaba lo que puede llamarse una "alfabetización liberadora", o sea, el ejercicio más activo e independiente de la lectura" (TANCK DE ESTRADA, 1988, p. 87).
} 
moldes das Escolas Pias ${ }^{42}$, nas quais os alunos deveriam ser agrupados de acordo com o nível de proficiência em leitura. Organizados deste modo, poderiam utilizar o mesmo livro, e o mestre dirigir seu ensino a grupos - ou seja, elas propunham um modo de ensino simultâneo. Assim, ao final do século XVIII, já era possível observar movimentos pedagógicos em que os novos materiais disponíveis (quadro-negro, caixas de areia, lousa individual de ardósia, "modelos") e os novos modos de agrupar os alunos redimensionam a relação didática ${ }^{43}$.

\subsection{O quadro-negro e o ensino simultâneo: a interação didática}

Nesta seção, vamos nos debruçar sobre dois instrumentos que ao longo do oitocentos foram introduzidos na sala de aula e implicaram em mudanças drásticas na relação didática: são os quadros-negros e os cartazes ("modelos"), ou seja, os suportes coletivos de leitura e escrita.

A introdução de suportes coletivos no século XVIII iniciou uma reorganização dos modos como se dava a relação didática: se antes cada aluno tinha sua cartilha e o professor auxiliava um a um de acordo com seu desenvolvimento, a inserção de reproduções em tamanho grande dos "modelos", de uso coletivo e contínuo, permite uma nova forma de uso do material escrito.

Se recomendava que fossem colocadas em cartazes para que estivessem a vista de todo o grupo. Se sugeria também que o professor copiasse os modelos em umas tábuas

\footnotetext{
${ }^{42}$ A referência poderia também ser vinculada à proposta dos Irmãos das Escolas Cristãs, de Jean-Baptiste de La Salle, no entanto, nas fontes apresentadas por Tanck de Estrada, não se faz referência ao grupo francês; já em relação aos Padres das Escolas Pias, aparecem com certa frequência, despontando como forte influência na promoção do ensino da leitura no território da Nova Espanha.

${ }^{43}$ É importante relacionar o redimensionamento da relação didática (mestre-aluno) ao próprio processo de formação da forma escolar moderna. De acordo com Razzini (2008, p. 99), o modelo antigo de escola primária geralmente se resumia a uma sala de aula incrustada na casa do professor, na igreja ou subvencionada pelo governo, organizada em pequenas turmas de alunos de diferentes idades e níveis de aprendizagem. Nessa estrutura, temos o chamado modo individual de ensino, pois o mestre necessitava ajustar o ensino para cada aluno. Tal modelo, conhecido hoje no Brasil como "escolas isoladas", só deixou de ser o mais comum nas áreas urbanas com a implantação dos grupos escolares, abrigados em prédios construídos especificamente para o ensino primário. Nos grupos escolares, foi possível o agrupamento de um número muito maior de alunos em um único local, o que viabilizou a organização de turmas mais heterogêneas, permitindo, assim, a reorganização da relação mestre-aluno para o modo de ensino simultâneo: o mesmo ensino para crianças com níveis de aprendizagem similares.
} 
de tela pintadas de preto com óleo (uma espécie de quadro-negro). (TANCK DE ESTRADA, 1988, p. 81, tradução nossa). ${ }^{44}$

Assim, os suportes coletivos, seja a lousa de ardósia coletiva na Europa ou as tábuas pintadas de preto na América Latina, tornam viável a organização do ensino simultâneo. "Cada um desses objetos mereceria um estudo aprofundado. É o caso do quadro negro, superfície coletiva apagável, que permite a generalização do ensino simultâneo inventado pelos Irmãos das Escolas Cristãs" (HÉBRARD, 2001, p. 121).

No detalhado estudo sobre o quadro-negro desenvolvido por Barra (2013), é possível compreender que sua forma atual, ou seja, coletiva, nasce em um longo processo que envolve desde o aperfeiçoamento da lousa de ardósia individual até adequações relacionadas ao número de alunos atendidos por sala. Recuperando o verbete "ardósia" do dicionário de termos pedagógicos, salienta: “Conhecida como 'pedra', 'laje' ou 'lousa', a ardósia surgiu numa época em que se queria ensinar aos pobres e, pode-se acrescentar, coincidiu com a chegada dos 'meninos' à escola" (p. 122). De acordo com a autora, os diretores das escolas mútuas foram os responsáveis por difundir o emprego escolar da ardósia em substituição às caixas de areia e como antecessora do papel e da pena metálica. O uso da ardósia foi bastante amplo até meados do século XIX, quando surge a "ardósia artificial"45, que teria a finalidade de ter melhor usabilidade pelos alunos, pois a ardósia natural era frágil, fria e dura (BARRA, 2013, p. 125). Com o intuito de aperfeiçoar o suporte de escrita, incrementam ainda a estrutura descrita acima com seu enquadramento em madeira. No entanto, como persistem inconvenientes de uso,

[...] introduz-se o quadro-negro, uma prancha de madeira de dimensões maiores suportada por cavaletes, regulável por tarraxas na altura e inclinação da prancha, de superfície pintada de cor escura, para ser usada com giz, um material com mobilidade, isto é, portátil. (BARRA, 2013, p. 125).

Nesse movimento, o suporte se desloca do individual para o coletivo, sendo atribuída à empreitada à Jean-Baptiste de La Salle.

\footnotetext{
44 "Se recomendaba colocarlas en carteles para que estuvieran a la vista de todo el grupo. Se sugería también que el maestro copiara las muestras en unas tablas de tela pintada de negro con óleo (una forma de pizarrín)" (TANCK DE ESTRADA, 1988, p. 81).

${ }^{45} \mathrm{~A}$ ardósia artificial consistia em uma lâmina de folha de ferro esmaltada ou uma folha de cartão coberta por uma massa delgada de madeira pintada de preto.
} 
[...] o quadro-negro teria surgido entre o final do século XVIII e o início do século XIX. Em ambos os registros, é um instrumento de ensino coletivo, que aparece vinculado à simultaneidade do ensino de ler e escrever. É material escolar que marca o método de ensino de transmissão simultânea e divide espaço, tempo e exercícios com a ardósia de uso individual. Inventado pelos irmãos lassaleanos, o quadro-negro seria rapidamente absorvido por outras práticas de ensino, como as de ensino mútuo. (BARRA, 2013, p. 126, grifos nossos).

É o advento do material escolar de caráter coletivo que promove a transição da organização do ensino individual para o ensino simultâneo. A autora salienta ainda que o princípio da simultaneidade era manifesto pela necessidade de que os alunos tivessem livros iguais para que pudessem desenvolver a mesma lição, condição que impossibilitava a organização de grandes grupos sob a tutela de um mesmo professor.

Sendo o livro um material de alto custo e tendo La Salle a preocupação com a vulgarização da instrução elementar para as classes populares, a substituição do livro por quadros impressos com as lições de leitura não apenas marca a importância do material na instituição do método de ensino, como confere ao caráter coletivo do material escolar as propriedades da racionalidade dos procedimentos metodológicos de ensino e revela o cunho social do método. (BARRA, 2013, p. 127).

Assim, nos moldes da proposta de La Salle, o uso de suportes ampliados permitindo a leitura coletiva era condição fundamental no cenário econômico da época para viabilizar o ensino dos mais pobres, além da promoção do ensino da leitura concomitantemente ao da escrita. Nota-se ainda que a inserção de um suporte de leitura coletiva implica em toda uma reordenação corporal dos alunos e da interação do grupo de alunos e professor.

[...] a presença do quadro-negro redefine a disposição espacial da aula. Material coletivo de uso privilegiado do professor, o quadro-negro indica a todos da classe a lição que deve ser executada. O olhar vertical do aluno é dirigido pelo plano horizontal da lousa individual, enquanto o plano vertical do quadro-negro dá a direção horizontal do seu olhar. Há uma redefinição espacial da aula, do mobiliário escolar, especialmente dos bancos e das bancas (mesas), dos agentes e das relações de ensino. (BARRA, 2013, p. 130 , grifos nossos). 
De fato, os modos ${ }^{46}$ de organização do ensino e, consequentemente, a relação didática decorrem diretamente de quais instrumentos são empregados na relação didática. Também no caso do Brasil, Frade assinala com clareza essa distinção. O modo de ensino individual, empregado no início da construção dos sistemas escolares, se realizava "mediante uma intervenção e proporção direta de um professor para cada aluno" (FRADE, 2007, p. 29). Sendo assim, cada aluno demandava, para além de um discurso específico elaborado pelo mestre, um material peculiar, que poderia ir desde cartilhas, caixas de areia e lousa de ardósia individual até sofisticados cadernos, penas e tinteiros, para os grupos mais abastados. Já o modo de ensino mútuo ou monitorial (lancasteriano), objetivava ensinar conteúdos diferentes no mesmo espaço a um grupo de alunos enorme e heterogêneo, tendo o professor como o principal responsável e seus alunos mais adiantados o papel de monitores dos menos escolarizados; cada grupo de monitoria demandava um material diferente.

Os materiais também eram diferenciados para leitura: tábuas com o alfabeto afixadas na parede e próximas aos alunos que se dedicavam apenas a esta atividade, quadro de sílabas para alunos mais adiantados e a utilização de objetos de escrita como caixa de areia para quem se iniciava nos gestos de escrita ou papel para os iniciados. (FRADE, 2007, p. 29).

A autora ainda salienta que as diferentes formas de organizar a relação didática entre professores e alunos condicionam as maneiras com que se trabalha os conteúdos e destaca que essas escolhas têm ainda maior influência na alfabetização.

Voltando nossa atenção ao modo como se difundiu o ensino simultâneo no seio do projeto republicano brasileiro, época em que os conteúdos a serem abordados na escola se tornavam cada vez mais complexos, é importante analisarmos como a questão material se altera em decorrência dos novos interesses políticos e econômicos. De acordo com Razzini, no Brasil republicano, a organização do ensino no modo simultâneo foi concretizada por meio da implantação dos grupos escolares abrigados em prédios construídos especificamente para o

\footnotetext{
${ }^{46}$ Utilizaremos o termo "modos" de ensino para a organização interacional da sala de aula, a saber: individual, simultâneo e mútuo/lancasteriano/monitoral. Já o termo "método" se vincula aos modos como o professor organiza a relação do saber com o estudante: intuitivo, transmissivo, construtivista, entre outros (cf. RAZZINI, 2008, p. 100). De acordo com Frade (2007, p. 22), o termo "metodologia" pode ser empregado tanto para os modos de organização escolar quanto para a base conceitual de relação dos modos com os quais o ensino promove 0 encontro entre o aluno e o saber.
} 
ensino primário. Nesses grupos, foi possível o agrupamento de um número muito maior de alunos em um único local, o que viabilizou a organização de turmas mais heterogêneas, o que permitiu a reorganização da relação professor-aluno para o modo de ensino simultâneo: o mesmo ensino para crianças com níveis de aprendizagem similares. A autora ainda aponta que a adoção do modo simultâneo "facilitava a organização de um programa de ensino unificado e graduado, além de melhorar a inspeção dos alunos e do trabalho do professor" (RAZZINI, 2008, p. 99). Essa forma de organizar o ensino exigia um arsenal de materiais didáticos como meio indispensável de assegurar a uniformidade e o cumprimento dos programas graduados de ensino, exigência que abriu um vasto campo de produção de materiais didáticos, conforme atesta a autora:

[...] a uniformização e seriação dos conteúdos e a adoção do ensino simultâneo para toda a sala apontam uma mudança importante para a produção de material escolar, pois obrigam que cada aluno tenha seu próprio material escolar, aumentando consideravelmente a demanda por produtos, tais como: "Livros, cadernos, ardosias, canetas e lápis são de uso individual. Todos os alumnos do curso primário elementar devem possuir o seguinte: caderno para exercícios escriptos; uma ardósia; um primeiro livro de leitura". (BITTENCOURT, 1908, p. 141 apud RAZZINI, 2008, p. 101, grifos nossos).

Assim, a organização do ensino simultâneo por meio do qual se concretiza a própria ideia de homogeneização das classes em função do desempenho na leitura e escrita, opera de modo eficiente para o controle de atividades pela escola e pelo professor e gera de maneira inerente uma "padronização de materiais individualizados, tais como cartilhas e outros livros para uso de todos" (FRADE, 2007, p. 29). Desse modo, é curioso notarmos como a estratégia de criar suportes coletivos, como o quadro-negro, foi desenvolvida nos setecentos com o intuito de tornar economicamente viável o ensino das classes mais pobres, instituindo assim o modo de ensino simultâneo, no entanto, esse mesmo modo de organização concebido por sua viabilidade econômica, aproximadamente um século mais tarde, no início de 1900, cria um mercado absolutamente novo, demandando todo um conjunto de utensílios que deveriam ser adquiridos pela família ou disponibilizados pelos próprios sistemas públicos de ensino, gerando um enorme mercado consumidor a ser explorado. 
A seguir, analisaremos como o ensino da leitura e da escrita é desenvolvido ao longo do século XIX e início do século XX, quando os sistemas nacionais de ensino já se encontram mais estruturados e dispondo dos materiais comuns à escola moderna, até os dias atuais.

\title{
1.4. As inovações e permanências no ensino da leitura e da escrita no século XIX
}

Após analisarmos os processos vinculados ao ensino das primeiras letras ao longo dos séculos XVII e XVIII e suas inter-relações com os modelos de letramento e aos materiais disponíveis à cada época, veremos como em um movimento de permanências e inovações a escrita vai ganhando, pouco a pouco, seu espaço na escola até ter extremo destaque. Para iniciarmos a análise, retomaremos o caso da França.

\begin{abstract}
A partir do século XIX, no entanto, a rede escolar tinha se desenvolvido e esses novos objetivos de aprendizagem diziam respeito a todos os alunos (muitos dos quais não falavam francês). $O$ fracasso na aprendizagem inicial subiu como uma flecha e se tornou o leitmotiv dos discursos pedagógicos. Os professores continuam a fazer decorar os livros de leitura, como no tempo dos catecismos. Foi preciso esperar a difusão de outra tecnologia (penas metálicas e papel de celulose, por volta de 1850) para que a aprendizagem simultânea da leitura e da escrita permitisse ultrapassar esse obstáculo. (CHARTIER, A-M., 2016, p. 291).
\end{abstract}

A partir do relato de Anne-Marie Chartier, observamos que em meio a práticas já sedimentadas no ensino da leitura, como a repetição de textos conhecidos de memória, a possibilidade de introduzir o ensino da escrita de maneira concomitante ao da leitura desponta como uma inovação escolar frutífera, elevando os resultados da aprendizagem da leitura. Assim como na França, no México do século XIX observam-se documentos que salientam como o ensino simultâneo da leitura e da escrita vem frequentemente à baila nos debates acerca de quais seriam os melhores métodos e materiais voltados ao ensino, fomentando mudanças nas práticas escolares.

Além de mudar a maneira de organizar o ensino, durante as primeiras décadas do século XIX foram introduzidos novos métodos para ensinar a leitura e a escrita. Sob a influência do pedagogo espanhol Vicente Naharro, começou-se a usar a silabação como um primeiro passo na instrução, em vez da soletração. Mudanças também foram 
introduzidas na prática educacional que vinha ocorrendo há séculos, na qual o aluno aprendia a ler e apenas meses ou anos depois, aprendia a escrever. Durante as primeiras décadas do século, especialmente nas escolas lancasterianas, a leitura e a escrita foram ensinadas ao mesmo tempo; a formação de letras foi uma ajuda para aprender a ler, em vez de ser um assunto separado e subsequente. (TANCK DE ESTRADA, 1990, p. 141, grifos nossos, tradução nossa). ${ }^{47}$

Assim, aponta-se como grande inovação o ensino concomitante da leitura e da escrita. No entanto, a escrita é introduzida assumindo o papel de instrumento para a aprendizag em da leitura, ou seja, neste primeiro momento de sua introdução na escola elementar, ela não havia adquirido o status de objeto de ensino. Os manuais de aplicação do modo de ensino lancasteriano que circulavam na época apresentavam diversos motivos para que o ensino da escrita ocorresse de modo concomitante ao da leitura, mesmo que o objetivo final ainda fosse o ensino da leitura e que a escrita atuasse de maneira instrumental para o ensino da primeira. Assinalam, em primeiro lugar, que o modo lancasteriano era viável do ponto de vista econômico, pois previam muito pouca utilização de papel (tanto folhas e cadernos quanto livros) e, em seguida, apresentam justificativas pedagógicas:

Duas vantagens foram alcançadas com esta técnica. Por um lado, era muito mais barato, já que Lancaster não usava papel e plumas, que eram caras, mas areia e palitos ou ardósias e lápis de ardósia. Por outro lado, ensinar a escrever junto com a leitura tinha vantagens pedagógicas: era mais rápido e menos entediante. [...] Como Lancaster observou: "Em qualquer lugar a areia é um substituto mais barato que os livros". Na segunda classe, se usavam ardósias e lápis de ardósia. Aprendiam a reconhecer e escrever letras cursivas e, a partir de então, praticaram a leitura e a escrita de sílabas de duas letras. Os alunos aprenderam a usar o lápis de ardósia como se fossem penas. A combinação da visão, da audição e da atividade manual facilitava a aprendizagem e permitiu maior participação e atenção entre os alunos. Neste sistema, escrever, no começo, é mais usado como meio de instrução do que como um fim em si mesmo. As crianças aprenderam a ler letras, sílabas e palavras, escrevendo-as em suas ardósias antes de lê-las nos cartazes ou em seus livros. (TANCK DE ESTRADA, 1990, p. 149, grifos nossos, tradução nossa). ${ }^{48}$

\footnotetext{
47 “Además de cambiar la manera de organizar la enseñanza, durante las primeras décadas del siglo XIX se introdujeron nuevos métodos para enseñar a leer y a escribir. Bajo la influencia del pedagogo español Vicente Naharro, se empezó a emplear el silabeo como primer paso en la instrucción, en vez del deletreo. También se introdujeron cambios en la práctica educativa que venía de siglos atrás, por la cual el alumno aprendía primero a leer y sólo meses o años más tarde, a escribir. Durante las primeras décadas del siglo, especialmente en las escuelas lancasterianas, se enseñaba a leer y escribir al mismo tiempo; la formación de las letras era una ayuda para el aprendizaje de la lectura, en vez de ser una asignatura separada y posterior" (TANCK DE ESTRADA, 1990, p. 141).

48 "Se lograban dos ventajas con esta técnica. Por una parte, era mucho más barato, ya que Lancaster no usaba papel y plumas, que eran caros, sino arena y palitos o pizarras y pizarrines. Por otra parte, enseñar la escritura
} 
Assim, mesmo garantindo exercícios de escrita desde as turmas iniciais por meio da utilização de substitutos economicamente mais viáveis ao papel, as justificativas pedagógicas assinalam fatores de duas ordens: a primeira, com um viés cognitivo, afirmando que a atividade manual (traçar letras) atuaria de modo a otimizar o processo que antes contava apenas com a visão e a audição; a segunda tem um caráter disciplinador, típico da forma escolar, quando afirma que ao combinar as três atividades (visão, audição e atividade manual) garantia-se maior engajamento dos alunos nas tarefas propostas. No entanto, apesar da inovação de articular o gesto motor (treino das letras) ao ensino das primeiras letras, observa-se o movimento de permanência de práticas tradicionais, como a soletração, agora associada à silabação, de caráter mais moderno, práticas que antecederiam e dariam as condições para que o aluno fosse capaz de ler palavras e frases inteiras. Ainda, assinala-se outra permanência: as frases lidas eram, muitas vezes, conhecidas de cor.

O ensino da leitura nas escolas lancasterianas não oferecia maiores inovações. Continuavam utilizando a soletração, embora combinada com a silabação. A Cartilha Lancasteriana dizia: "O instrutor diz, por exemplo, bon-dad; o primeiro discípulo soletra a primeira sílaba b, o, n, bom; o segundo a segunda sílaba d, a, d, dad e o terceiro une as duas sílabas bondad. Depois de saber soletrar e silabar o aluno lia palavras inteiras e frases, muitas das quais já sabia de memória pois eram textos ou lemas conhecidos. (TANCK DE ESTRADA, 1990, p. 152, grifos nossos, tradução nossa). ${ }^{49}$

Enquanto esse movimento em torno do ensino concomitante da leitura e da escrita se desenvolveu no México desde a primeira metade do século XIX, no Brasil o movimento é mais tardio. Abordando as publicações do século XIX que circularam no Brasil, Frade assinala que a

junto con la lectura tenía ventajas pedagógicas: era más rápido y menos aburrido. [...] Como observó Lancaster: 'En cualquier lugar la arena es un sustituto más barato que los libros'. En la segunda clase se usaban pizarras y pizarrines. Aprendían a reconocer y escribir letras cursivas y de ahí en adelante practicaban la lectura y la escritura de silabas de dos letras. Los alumnos aprendían a tomar y utilizar los pizarrines como si fueran plumas. La combinación de la vista, el oído y la actividad manual facilitaba el aprendizaje y permitía mayor participación y atención entre los estudiantes. 'En este sistema, la escritura, al principio, está utilizada más como un medio de instrucción que como un fin en sí mismo. Los niños aprendían a leer letras, sílabas y palabras, al escribirlas en sus pizarras antes de leerlas en los carteles o en sus libros'" (TANCK DE ESTRADA, 1990, p. 149).

49 "La enseñanza de la lectura en las escuelas lancasterianas no ofrecía mayores innovaciones. Se seguía usando el deletreo, aunque se combinaba con el silabeo (como ya era práctica común en el siglo xix). La Cartilla lancasteriana decía: 'El instructor dice, por ejemplo, bon-dad; el primer discípulo deletrea la primera sílaba b, o, n, bon; el segundo la segunda sílaba $d, a, d$, dad y el tercero une las dos silabas, bondad'. Después de saber deletrear y silabear el alumno leía palabras enteras y frases, muchas de las cuales ya sabía de memoria porque eran textos o lemas conocidos" (TANCK DE ESTRADA, 1990, p. 152). 
profusão de obras dessa época que já no próprio título remetiam à leitura é um indicador de que "o aprendizado inicial é marcado com um ritual de passagem específico para leitura e não necessariamente para a escrita" (FRADE, 2011b, p. 180). Além da análise dos títulos das obras que aqui circularam, Razzini (2008) e Frade (2011b) apontam que no Brasil é ao final do século XIX que começam a ser publicados os discursos metodológicos que defenderiam o ensino concomitante da leitura e da escrita ${ }^{50}$. O trecho abaixo traz um exemplo de orientação acerca do ensino das primeiras letras feita por um periódico especializado, a Revista Pedagógica:

Todos sabem quanto é ingrato e fastidioso o estudo dos primeiros elementos da leitura. Dos processos inventados para torná-lo mais attraente e mais rápido aquelle que satisfaz consiste no ensino simultâneo da escripta, da leitura e da orthografia: três conhecimentos que se auxiliam e completam de modo suavíssimo e natural. Não se trata de fazer um curso regular de calligraphia, nem de ortographia. Logo que as crianças conhecem um elemento (vogal, consoante, syllaba ou palavra) o professor escreve esse elemento no quadro preto e as crianças reproduzem-no primeiro nesse quadro, depois nas ardósias e finalmente nos cadernos, empregando sucessivamente o giz, o lápis de lousa e o lápis de plomibagina ${ }^{51}$. Habilitar o educando a ler com facilidade o que houver escripto e a reproduzi-lo de memória - eis o princípio fundamental do método. (PUJOL, 1893, p. 279 apud RAZZINI, 2008, p. 94, grifos nossos).

Em consonância com as afirmações das autoras, vale citarmos como marco representativo na promoção do ensino concomitante da leitura e da escrita no Brasil a "Cartilha Nacional" (ou "Novo primeiro livro de leitura"), de 1885 e autoria de Hilário Ribeiro, para "o ensino simultâneo de leitura e escrita", obra que alcançou um número extraordinário de exemplares, tendo sido reeditada até pelo menos 1959, data de sua 245a edição (RAZZINI, 2008, p. 93). Outro advento importante relacionado à viabilidade do ensino da escrita que também data dos oitocentos é a popularização do lápis grafite. Sua difusão é atestada pelo aumento das fábricas de lápis nos Estados Unidos e na Europa. ${ }^{52}$ Já no Brasil, houve um longo período de transição, porém irreversível, do uso da lousa individual para o uso do caderno e do lápis grafite.

\footnotetext{
${ }^{50}$ Em meados do século XIX, no Brasil, ainda se observavam a publicação de métodos que separavam o ensino da leitura e da escrita, como no caso do método de Antônio de Carvalho, que publica em 1850 duas obras: uma voltada para o ensino da leitura e outra voltada para o ensino da escrita (RAZZINI, 2008, p. 93).

${ }^{51}$ Grafite.

${ }^{52}$ Cf. RAZZINI, 2008.
} 
A generalização do uso do lápis, da pena e do caderno aponta, ainda, mudanças nas práticas de sala de aula, principalmente a diminuição dos exercícios orais, relacionadas às críticas feitas pelos propugnadores do método intuitivo ao ensino mnemônico da "decoreba" mecânica, o que pode ter contribuído também para o aumento dos exercícios escritos. (RAZZINI, 2008, p. 105).

A popularização do lápis grafite e do papel permite que o método de ensino da leitura transite de exercícios de soletração e de silabação para exercícios de cópia, conforme atestava a "Revista Pedagógica": "Habilitar o educando a ler com facilidade o que houver escripto e a reproduzi-lo de memória - eis o princípio fundamental do método" (PUJOL, 1893, p. 279 apud RAZZINI, 2008, p. 94). A afirmação do instrutor de ensino em 1893, traduz de modo praticamente idêntico o verbete "cópia" do glossário Ceale: "Copiar é guardar um texto mentalmente e ditá-lo a si mesmo em etapas" ${ }^{53}$. A ampla utilização da cópia também foi observada na França, conforme assinala Anne-Marie Chartier (2016, p. 291): “A memorização das sílabas deixou de ser feita por meio da soletração oral, pouco a pouco abandonada, e passou a se associar à cópia, em cadernos baratos, de linhas de sílabas e palavras ditadas".

Ainda de acordo com o glossário, a cópia é uma atividade clássica que perdurou nas escolas primárias e secundárias até as décadas de 1960 e 1970, quando passou a ser considerada um trabalho "mecânico", "passivo". Essa percepção está bastante relacionada a outro advento: o das fotocópias. A partir do momento em que as fotocópias passaram a existir, facilitando a reprodução dos textos e exercícios que seriam trabalhados em sala de aula, a cópia das lições pelos alunos tornou-se menos necessária e passou a ser questionada por educadores e teóricos de campos correlatos à Educação. Logo, dispondo da reprodução impressa de quaisquer textos passíveis de serem utilizados em sala de aula, o argumento das críticas realizadas acerca do uso da cópia nas atividades de ensino da leitura e da escrita relaciona-se ao longo período gasto pelos alunos ao copiar textos, tempo que seria melhor despendido em sala de aula para reflexões acerca do conteúdo dos textos abordados e para a produção de textos de autoria dos alunos.

Desse modo, ao longo de toda essa trajetória, cabe-nos perguntar quando a escrita ganha status efetivo de objeto de ensino na escola elementar. No caso da França, Anne-Marie Chartier aponta que o programa de 1830 instaura o ensino de "elementos da língua francesa",

\footnotetext{
${ }^{53}$ Fonte: Glossário Ceale - Termos de Alfabetização, Leitura e Escrita para Educadores.
} 
sendo que nessa mesma época surgem os ditados com foco no treino ortográfico, exercícios de conjugação e análise gramatical das palavras. Alguns anos depois, em 1850, as autoridades escolares francesas orientam os professores a realizarem exercícios de composição escrita nas aulas de língua materna, designados como "composição francesa" ou "redação de estilo" (CHARTIER, A-M., 2007, p. 41). Essa época está bastante atrelada à popularização do papel, o que permitia uma modalidade de escrita mais permanente e, consequentemente, avaliável. De acordo com Frade (2011b, p. 66), o uso das caixas de areia e das lousas de ardósia individuais promovia uma escrita de duração efêmera, além do espaço extremamente restrito para o desenvolvimento de um maior volume de escrita. Assim, antes de haver papel disponível para todos, o que era ensinado aos alunos por meio desses suportes estava muito mais relacionado ao aprendizado da técnica de traçados, da técnica gráfica, do que ao aprendizado efetivo da escrita de textos.

No entanto, é necessário analisarmos que a escrita assume, pouco a pouco, um papel central na instituição escolar. Mais que o mero status de objeto de ensino, ela se transforma em importante dispositivo disciplinar, como atesta a orientação de finais dos oitocentos:

O mestre hábil principia cedo o ensino de escrever, pois que, sabendo o menino escrever, tudo vai prestes, e logo sobrevem bom emtendimento de orthografia. Alem dísso em escóla numerosa, o melhór meio de ter os meninos quietos e assental-os a escrever. (CAMPAGNE, 1886, p. 880 apud BARRA, 2013, p. 131).

De fato, a escrita escolar não está circunscrita ao ensino das primeiras letras e à disciplina de língua materna. Sua utilização na escola ganha tamanha proporção que se torna impossível a dissociação entre escrita e escola. Frade assinala que "a própria escola se confunde com a escrita" em virtude da dupla atividade desempenhada pela escrita no contexto escolar.

Entre diferentes funções, a escrita pode ocupar um valor instrumental e a escola também pode se utilizar da escrita como forma de ocupação dos alunos, ou seja, como dispositivo disciplinar. Sendo assim precisamos ter em conta estas diversas funções cumpridas pela cultura escrita na escola, ao buscar distinguir seu lugar como componente do ensino e objeto a ser ensinado. (FRADE, 2008, p. 2, grifos nossos).

Tornando-se parte fundamental da cultura escolar, precisamos observar que algumas práticas de escrita não se tornam canônicas por serem as mais ajustadas à aprendizagem dos 
conteúdos pelos alunos, mas acabam por se tornar clássicas justamente por serem bem administráveis na relação didática do modo de ensino simultâneo - relação didática na qual um professor ensina a um grande número de alunos - e por disporem de materiais para o seu desenvolvimento, sendo seus principais exemplos o ditado, a caligrafia e a cópia.

Supõe-se que algumas delas ultrapassam seu objetivo, em termos de conteúdo, e se tornam canônicas justamente por serem bem administradas na gestão da sala de aula, por permitirem o manuseio de instrumentos e materiais ou por ocuparem os alunos e possibilitarem a administração dos tempos escolares (ditado, exercícios de caligrafia, cópia ou outra produção escrita). (FRADE, 2011b, p. 193-194).

O relato de Anne-Marie Chartier sobre o uso do ditado visando o ensino de ortografia nas escolas francesas coaduna com essa afirmação:

Para o professor, o exercício era muito cômodo: sua finalidade era clara, mobilizava a atenção dos alunos, durava exatamente o mesmo tempo para todo mundo, os alunos corrigiam eles mesmos sob o controle do mestre e a nota vinha imediatamente. Como se espantar com o fato de que, apesar de todas as críticas, o ditado tenha sobrevivido a todas as reformas pedagógicas até o século XXI? (CHARTIER, A-M., 2007, p. 34).

Para encerrarmos as reflexões sobre a escrita na escola elementar, a seguir, vamos refletir um pouco mais acerca do uso do caderno e como sua inserção na escola também repercutiu em importantes alterações na interação didática.

\subsubsection{O caderno: prova material do trabalho de ensino}

O caderno, considerado o suporte de escrita escolar por excelência ao lado do lápis e da caneta, seus instrumentos para registro, tardou a se popularizar nas salas de aula europeias e brasileiras.

[...] ele pode ser constituído em um conjunto de documentos característicos de um período importante da história escolar, o que se situa entre os anos 1860 e os anos 
$1960^{54}$. O caderno escolar é, nesse período, o suporte de uma prática de escrita que poderia ser a matriz de uma alfabetização escolar específica. (HÉBRARD, 2001, p. 120).

Para além do barateamento do papel, Razzini (2008, p. 101) aponta que a popularização do uso das folhas soltas e especialmente do caderno deveu-se em grande parte pelo fato de que "se constituía como prova material do trabalho do professor e dos alunos dos anos mais adiantados". Refletindo de maneira mais específica sobre as consequências do uso do caderno, Frade ressalta:

A presença do papel em outros materiais, como os cadernos, traz inúmeras consequências pedagógicas e cognitivas. A utilização do caderno escolar trouxe muitas possibilidades para a pedagogia, inclusive a do registro. As maneiras pelas quais esse registro foi sendo produzido constitui-se num artefato cultural que altera as relações com o conhecimento, sobretudo por separações e clivagens entre as disciplinas. (FRADE, 2011b, p. 66).

A longa transformação sofrida pelos suportes e riscadores de escrita na sociedade e suas implicações na vida escolar permitem que possamos refletir como cada uma dessas tecnologias da escrita requer uma gestualidade bastante específica e, consequentemente, impõe um determinado aprendizado. Portanto, aprender a escrever não significa apenas dominar o princípio alfabético do sistema de escrita, mas supõe, para além dele, o treino de um conjunto de habilidades que vão influir de maneira direta na proficiência escritora do sujeito.

[...] a presença ou ausência de materiais para inscrever (penas de ganso, lápis de pedra para lousa, penas metálicas, lápis) e para receber essa escrita (lousa, folhas soltas, cadernos, dentre outros) fazem com que a materialidade envolvida no ato de escrever seja, ora um problema para a execução da escrita na escolarização e, quem sabe, nas práticas sociais de seu uso, ora um condicionante para produção de novos gestos que precisam ser aprendidos na escolarização. (FRADE, 2011b, p. 181, grifos nossos).

Sendo assim, é possível afirmar que, tomados em sua materialidade, os objetos de escrita permitem a reconstrução tanto dos conteúdos ensinados quanto do conjunto de práticas ativado no interior da escola. É exemplo de como as práticas escolares sofrem interferências diretas desses artefatos a banalização do acesso ao papel e aos cadernos, quando se iniciam as

\footnotetext{
${ }^{54}$ É importante assinalar que, segundo Hébrard, este segundo limite poderia ser justificado pela aparição, ao longo da década de 1960, de novos instrumentos (caneta esferográfica, caneta hidrográfica), novos suportes em folhas (os de listar, as fichas policopiadas para completar, os fichários editados) e, sobretudo, da assimilação do caderno aos arcaísmos pedagógicos que as inovações dos anos 1970 vão combater.
} 
críticas sobre a permanência dos antigos suportes e riscadores - a lousa de ardósia individual e o lápis de ardósia -, conforme a orientação de Ramon Roca Dordal na "Revista de Ensino", em 1912:

Todo instrumento que não seja aquelle que o educando há de utilizar mais tarde, é trabalho que, quando não tivesse outros inconvenientes, seria inútil. $O$ educando precisa aprender a escrever em papel e não em lousa, e esta, pela sua dureza, não prepara para poder facilmente escrever em papel. (DORDAL, 1912, p. 33-34, apud RAZZINI, 2008, p. 103).

Desse modo, observamos como a inovação dos materiais geram efeitos diretos nas práticas de ensino. A presença ou ausência de materiais para inscrever (penas, lápis, canetas) e para receber a escrita (lousa individual, folhas, cadernos) faz com que a materialidade do ato de escrever implique diretamente tanto na produção de novos gestos, que precisam ser aprendidos na escolarização, quanto no desenvolvimento de exercícios e tarefas específicas atrelados à escrita, alterando a interação em sala de aula e, especialmente, o tempo escolar.

[...] o uso deles [cadernos] parece constituir, depois da metade do século XIX até hoje, uma parte essencial do tempo escolar; e, enfim, porque gostaríamos de mostrar que, no momento mesmo em que o exercício se torna o centro do trabalho escolar de alfabetização, o caderno não só se oferece como suporte do mesmo, mas ainda the confere a sua verdadeira significação. (HÉBRARD, 2001, p. 122, grifos nossos).

É por meio do uso do papel que a escrita ensinada na escola elementar ganha permanência: com o papel, se escreve para o outro ler, e não a penas para praticar as letras ou apoiar a aprendizagem da leitura. É nesse contexto que problemas relacionados à legibilidade do que se escreve exigem que se instaurem longos exercícios de caligrafia ${ }^{55}$.

Ao lado do caderno, podemos salientar o amplo uso das canetas esferográficas, que invadiram os estojos dos estudantes a partir de 1960:

Daí por diante os professores não puderam mais ensinar a escrita da mesma forma: não havia mais mata-borrão nem tinteiro sobre as carteiras, não havia mais exercícios de manutenção para que a pena não espirrasse tinta, não havia mais traços espessos ou finos. A esferográfica mudou ao mesmo tempo os gestos gráficos e o imaginário social das práticas de escrita. (CHARTIER, A-M., 2007, p. 42).

\footnotetext{
${ }^{55}$ O estudo desenvolvido por Vidal e Gvirtz (1998) detalha a amplitude do ensino da caligrafia na escola elementar.
} 
Essa breve reconstituição histórica mostra que as práticas escolares de escrita desenvolvidas na atualidade são fruto de um longo processo de transformações oriundas de motivações econômicas, sociais e culturais. Vimos como a viabilidade econômica dos materiais disponíveis atua diretamente na exequibilidade de seus usos, como a ausência de "pautas" 56 nas folhas disponíveis para exercício, além do incansável e perigoso exercício de aparar as plumas, extinto na França apenas em meados do século XIX, com a introdução das penas metálicas. As restrições e possibilidades de cada material deixaram marcas na cultura escolar que podem ser recuperadas na memória de pessoas que passaram pela escola elementar há algumas décadas, como quando os canhotos, mesmo dispondo de lápis e canetas esferográficas, precisavam aprender a utilizar a mão direita. Esse exemplo é uma espécie de vestígio da escola que ensinava a escrever com canetas tinteiro.

Isso nos ajuda a compreender por que, até o século XVII, a escrita só podia ser ensinada aos alunos maiores. Sua concretização, efetuada com o uso da pena de ganso, mobilizava a destreza no aparo e limpeza do instrumento da escrita com canivete. Similarmente, ajuda-nos a perceber por que ainda nas décadas iniciais do século XX não era permitido ao canhoto usar a mão esquerda para escrever. A tinta da caneta demorava a secar. Como escrevemos da esquerda para a direita em uma linha horizontal, era necessário ser destro para não borrar o papel. Mudanças de ordem pedagógica somente puderam ser implementadas no momento em que inovações tecnológicas surgiram, como a lousa individual, no Setecentos, ou a caneta esferográfica nos anos 1940. (VIDAL, 2014, p. 10).

Por fim, são muitas as marcas que os instrumentos de escrita imprimem nas práticas didáticas, ou, como já nos mostrou Soares (2016), os métodos para ler e escrever surgiram de modo muito afinado com o material que se dispunha e não estavam relacionados a teorias acadêmico-científicas. Essas diferentes práticas recebem a todo tempo orientações teóricas que poderiam fomentar inovações, no entanto, determinadas práticas criticadas pela academia muitas das quais são extremamente interessantes do ponto de vista do interior do funcionamento escolar, como o ditado - despontam como importantes elementos de

\footnotetext{
${ }^{56}$ Segundo Tanck de Estrada (1988, p. 80), a impossibilidade de o professor traçar tantas linhas em tantas folhas de papel quantas fossem necessárias para atender a todos os alunos levou ao desenvolvimento de um aparato chamado "pauta": uma tábua de madeira com cordas esticadas que permitiam o traçado rápido das linhas de toda uma folha.
} 
permanência na cultura escolar e atestam a relação entre a escrita e a organização da própria instituição.

Na próxima seção, vamos problematizar como a inserção das tecnologias digitais de produção e circulação de textos está influenciando as práticas escolares na atualidade.

\subsection{Os novos suportes e o ensino da escrita}

Hoje, nos preocupam quais são as possibilidades e os efeitos das novas tecnologias - as tecnologias digitais - nas práticas de leitura e escrita desenvolvidas na sociedade e suas repercussões na escola elementar. Tendo em vista que não basta o mero aprendizado do sistema de escrita para que os alunos participem de práticas sociais, é necessário que se ensine a manejar diferentes e novos artefatos relacionados à cultura escrita, pois ler e escrever textos na atualidade abrange, sobretudo, i) práticas interativas de leitura e escrita e ii) leitura e produção de textos envolvendo múltiplas linguagens, como imagem, som e vídeo (ROJO, 2017). Conforme assinala Anne-Marie Chartier:

As situações interativas se tornaram a norma a partir do momento em que os suportes de leitura passaram a ser máquinas, mas a chegada de ferramentas digitais permitiu que uma nova fronteira fosse ultrapassada, marcando um ponto sem retorno. Basta observar os adolescentes que "batucam" em seus smartphones. Para eles, ler é comunicar. [...] Todas as revoluções da leitura decorreram de inovações tecnológicas que modificaram ao mesmo tempo a materialidade e o objetivo dos textos. (CHARTIER, A-M., 2016, p. 292).

Nas páginas anteriores, discutimos, com base em uma perspectiva histórica, como as inovações tecnológicas modificaram a materialidade, o objetivo e os modos da sociedade se relacionar com os materiais da cultura escrita. Todas essas transformações alteram também a relação entre os instrumentos disponíveis para a escrita e seus efeitos nas práticas escolares, inclusive com os conteúdos dos programas de ensino.

Em síntese, podemos dizer que, para cada gesto, para cada alteração nas tecnologias de escrita, deveríamos pensar em novos gestos e possibilidades cognitivas e, por extensão, em novas pedagogias. Isso porque esses instrumentos alteram os modos de 
relacionamento com a cultura escrita e, em outra instância, com o próprio conhecimento e com uma instituição encarregada de transmiti-lo, a escola. (FRADE, 2011b, p. 67-68, grifos nossos).

Analisando as práticas de leitura e produção de textos na escola ao longo das últimas décadas, é possível afirmarmos que há o movimento de permanência e inovação por meio da articulação relacionada ao manuseio de materiais e práticas oriundas tanto da cultura impressa quanto da manuscrita. Os textos lidos são apresentados, majoritariamente, por meio de livros didáticos, fotocópias e livros de literatura, ou seja, materiais impressos. Ao mesmo tempo, o ensino da escrita se dá por meio da escrita manuscrita, que na atualidade está praticamente restrita ao ambiente escolar. Esse movimento de permanência e inovação mostra como o ensino do traçado das letras ainda perdura na rotina escolar, ao mesmo tempo em que no interior das práticas são utilizados com frequência textos impressos. Desse modo, podemos perguntar: ao realizar a escrita escolar, o aluno consegue projetar a dimensão social que seu produto escrito pode ou poderia alcançar fora dos muros da escola?

A escola parece ter mantido a exigência rígida de que os alunos dominassem uma escrita contínua, típica da cultura do manuscrito, transformando o aprendizado do traçado numa condição para a aprendizagem dos aspectos conceituais do sistema alfabético e ortográfico de escrita. (FRADE, 2011a, p. 69).

Partindo de reflexões acerca da permanência da cultura manuscrita associada à inovação da cultura impressa, vamos problematizar como a escola lida com o ensino da escrita e, especialmente, de textos que são produzidos e circulam em instrumentos e ambientes digitais multissemióticos e multimodais -, aplicando as possibilidades das ferramentas que os editores de texto e imagem apresentam. Observaremos essa problemática a partir da proposta de Vidal, que remete ao lugar central que os sujeitos ocupam na construção da cultura escolar.

[...] ao serem instados a introduzir as novas tecnologias da informação no cotidiano das aulas, não estão os professores exercendo a conhecida arte da docência, hibridando aspectos que consideram positivos das TICs às metodologias de ensino que estão acostumados a utilizar com sucesso em sua prática cotidiana? Ao se confrontarem com as reformas educativas e as novas solicitudes das políticas públicas, não estão alunos, professores e administradores constantemente negociando entre o possível de ser incorporado e o que é preciso descartar para manter o funcionamento da escola? (VIDAL, 2009, p. 39). 
É indiscutível que diversos profissionais das escolas públicas brasileiras estão, há mais de uma década, engajados nesse movimento de hibridização entre as novas tecnologias e as práticas já consolidadas na cultura escolar. ${ }^{57}$ No entanto, é necessário que as pesquisas em Educação trabalhem no sentido de promover um uso reflexivo e exequível das tecnologias digitais no interior das escolas.

Todas as revoluções da leitura decorreram de inovações tecnológicas que modificaram ao mesmo tempo a materialidade e o objetivo dos textos. O que vão produzir essas interações entre escrita, imagens e sons, impensáveis antes do ano 2000? É nessa direção que todos os jovens pesquisadores devem se voltar, antes mesmo que "autoridades" (internacionais? privadas? comerciais?) instituam o novo paradigma que modificará a definição que hoje temos em comum do letramento social e, em consequência, das formas de entrada das crianças na escrita. (CHARTIER, A-M., 2016, p. 292).

A formação de leitores e produtores de textos digitais competentes é urgente, tendo em vista a velocidade e quantidade de informação diversa que circula nos diferentes canais. $O$ não manejo das habilidades básicas de leitura e compreensão de textos digitais gerou uma nova categoria de analfabetismo, o "analfabetismo digital".

[...] o termo analfabetismo digital poderia ser utilizado para já alfabetizados que não alcançaram o domínio dos códigos que permitem acessar a máquina, manuseá-la e que, portanto, não podem utilizar seus comandos para práticas efetivas de digitação de texto, leitura e produção de mensagens para efeitos de interação à distância ou para uma leitura de informação ou mesmo de leitura e escrita de outras linguagens (visuais, por exemplo). (FRADE, 2011b, p. 74).

Assim como em relação a qualquer outro saber que circula no cotidiano da sociedade, os indivíduos já chegam à escola com algum conhecimento construído sobre os usos e funções desses produtos culturais. No entanto, o domínio restrito da tecnologia pode conformar os usuários em meros reprodutores de informação, sem que eles desenvolvam uma leitura crítica dos diversos textos que circulam socialmente e, especialmente, alija-los da condição de produtores de conteúdo - ou melhor, de textos -, e, no caso das tecnologias digitais, de textos multissemióticos, que garantiriam uma participação efetiva na sociedade da atualidade.

${ }^{57}$ Cf. LOPES, 2010. Abordaremos esse ponto em pormenores no capítulo 3. 
De acordo com Frade, o termo "alfabetização digital" é utilizado para nomear o aprendizado "da escrita que envolve signos, gestos e comportamentos necessários para ler e escrever no computador e em outros dispositivos digitais" ${ }^{58}$. Desse modo, para o desenvolvimento dessa aprendizagem é necessário que a alfabetização seja realizada com instrumentos digitais que trazem novas formas de produção, circulação e divulgação de textos multissemióticos.

No caso da alfabetização digital, se entrecruzam o uso do instrumento de registro, os usos sociais da escrita, os sistemas de representação (letras, sinais gráficos, ícones, cores, sonoridades, imagens fixas e em movimento) no mesmo suporte - e estas formas interferem mutuamente no gesto de escrever e no pensamento sobre o funcionamento da escrita. (ALFABETIZAÇÃO DIGITAL, 2014).

A aprendizagem dos novos gestos da escrita em instrumentos digitais envolve, em um primeiro momento, o manuseio e funcionamento do mouse, do teclado e da tela sensível ao toque. Esses dispositivos de interação com a máquina permitem a navegação em ponteiro, ou seja, que o usuário acesse ícones que são a "porta de entrada" para os programas que desejam utilizar. Assim, a iconicidade é extremamente presente quando pensamos na alfabetização digital, um saber que está bastante distanciado dos conhecimentos da escrita alfabética. São esses ícones que permitirão ao aluno iniciar uma tarefa no editor de texto, acessar o navegador de internet, transpor conteúdo de um espaço a outro e, por fim, gravar conteúdo produzido ou pesquisado de modo que possa ser recuperado em outro momento de trabalho.

A escrita no computador parece fazer parte de saberes não ensinados na escola, pois vários gestos presentes na cultura digital são aprendidos através de jogos, brinquedos eletrônicos, celulares, operações no comércio e bancos, e outras tecnologias móveis (como ligar, desligar, clicar, tocar em ícones, arrastar, baixar programas). Entretanto, a criança precisa e pode dominar diferentes técnicas relacionadas ao que se chama de usabilidade: aprender a lidar com as ferramentas do sistema para ligar a máquina; compreender o teclado, seus símbolos e a função de cada tecla para além de digitar as letras; operar com a tela, interagir com ícones, localizar programas, manusear o mouse de adulto com suas mãos pequenas (sabendo que ele tem mais de uma função), arrastar, clicar e desenvolver operações cognitivas que permitam memorizar e internalizar tais operações. Essas operações provocam efeitos nos escritos e na tela e, consequentemente, no conhecimento sobre o funcionamento mais técnico do novo

\footnotetext{
${ }^{58}$ Fonte: Glossário Ceale - Termos de Alfabetização, Leitura e Escrita para Educadores.
} 
instrumento de escrita. Esse tipo de alfabetização digital é um dos componentes do letramento digital, e ambos precisam ser ensinados na escola. (ALFABETIZAÇÃO DIGITAL, 2014).

No que tange o uso específico do processador de textos, Frade salienta:

Algumas pesquisas empreendidas por Emília Ferreiro evidenciam que o computador não interfere no conceito de representação da escrita alfabética. No entanto, seu uso influencia o aprendiz em várias questões: na noção de espaçamento e nas decisões sobre a disposição do texto em página; na experimentação de formas, cores e tamanho das letras; na percepção das marcas e correções automáticas de ortografia. Tendo em vista que a multimodalidade é muito potencializada no ambiente digital, a inter-relação entre signos sonoros, verbais e visuais pode exigir maior articulação entre sistemas ideográficos e alfabéticos. Com novos recursos de sonorização é possível que a criança explore as relações de simultaneidade entre o que tecla e/ou fala e o produto escrito que vê. Isso poderá, futuramente, interferir ainda mais no aprendizado do sistema de escrita. (ALFABETIZAÇÃO DIGITAL, 2014, grifo nosso).

De fato, os novos instrumentos de escrita acarretam novos saberes que irão compor os currículos da atualidade, assim como a aprendizagem de novos gestos. Nesse sentido, Frade (2011a, p. 77) destaca "o potencial de pelo menos, três recursos para o ensino inicial da escrita no contexto das novas tecnologias: o som (e nele a voz), a imagem e a escrita". Desse modo, explorar esses recursos implica em um profundo redimensionamento das práticas de ensino da escrita na escola elementar, pois ao integrarmos outras semioses na interação aluno, professor e texto, temos mudanças significativas nas atividades canônicas de escrita e produção de texto.

No entanto, apesar dos diversos estudos publicados que apresentam muitas propostas interessantes integrando o ensino da produção escrita com tecnologias digitais (COSCARELLI, 2011; FRADE, 2011a; RIBEIRO, 2016b; ROJO, 2017; ROJO; MOURA, 2012) - especialmente voltadas ao Ensino Fundamental 2 e Médio -, pouco se pensa nas alterações que o uso desses novos artefatos promove na interação em sala de aula, principalmente em turmas dos anos iniciais. As propostas de atividades publicadas nas obras mencionadas acima geralmente não contam com reflexões sobre como remanejar a interação em sala de aula, qual a quantidade de máquinas disponíveis e o que os alunos já precisam conhecer em termos de usabilidade - ou melhor, o quão alfabetizados digitais eles já são para desempenhar determinadas tarefas envolvendo o uso de computador ou de qualquer outra ferramenta digital. 
Vale ressaltarmos que a mera inserção da tecnologia digital nas aulas de língua materna pode representar um entrave no trabalho de ensino, pois é frequente a culpabilização do professor quando a incorporação das tecnologias digitais não ocorre. Ribeiro (2016a) alerta que é fundamental estarmos atentos aos discursos que apenas desqualificam a competência do professor no cumprimento de seu trabalho por desconhecer o funcionamento de determinadas ferramentas ou ser incapaz de incorporar as tecnologias digitais à prática didática. Assim, é importante que promovamos a reflexão sobre o porquê de as tecnologias digitais não serem integradas ao cotidiano pedagógico.

A questão que produz este diálogo em câmera lenta entre escola e tecnologias digitais reside em aspectos sociais e humanos, na interação entre professor, escola e aluno, em políticas de formação, em políticas de trabalho, muito mais que apenas em listas de compras em lojas de eletrônicos. (RIBEIRO, 2016a, p. 92, grifos nossos).

De fato, há toda uma reordenação interacional quando se insere a tecnologia digital na escola. A primeira e mais simples delas reside no mero ato de grafar letras. Vimos que historicamente a escola continua focada no ensino da grafia das letras. Vimos também que assim que o ensino da leitura se dava de maneira concomitante ao da escrita, as recomendações que seguiam as orientações visavam sempre o caráter disciplinar, no qual estava envolvida a postura, o gesto do aluno, que se senta e passa longas horas escrevendo, geralmente cópias ou ditados. A primeira diferença que nos vem à mente é a de que o aluno, ao utilizar o editor em lugar do papel, precisará lidar com o teclado. Essa troca libera imediatamente o aluno do trabalho de grafar as letras e o permite observar a própria produção em uma grafia nítida e socialmente prestigiada (FRADE, 2011a, p. 73).

Assim, não é apenas necessário inserir os artefatos digitais na escola, mas pensar em como toda a lógica escolar é construída com base na escrita, ou seja, o tempo escolar, os exercícios e toda a cultura escolar foi conformada pensando em tempos de cópias, ditados, traçar linhas coloridas para delimitar uma tarefa e outra, apontar o lápis, caprichar na letra, passar a limpo. Enfim, ao imaginarmos uma substituição do papel pela tela, não devemos pensar somente no modo como o professor, de maneira imensamente criativa, insere a tecnologia digital. O que precisamos pensar é em como toda a lógica escolar precisa ser reconfigurada, repensando o tempo e a qualidade das interações. Por exemplo, o caderno foi 
uma tecnologia que permitiu melhor organização e armazenamento das produções escritas dos alunos. Era possível ao professor recuperar textos anteriores, avaliar a evolução da aprendizagem do aluno, contabilizar a frequência às aulas etc. Para o aluno, o caderno foi uma tecnologia que permitiu controlar melhor seu próprio desenvolvimento, deixar as tarefas concentradas em um único suporte e rememorar o que já foi feito. Enfim, o caderno transformou qualitativamente o trabalho do professor e do aluno. Os discursos acerca das tecnologias digitais focam muito em como as ferramentas podem incrementar o processo de aprendizagem, mas não problematizam questões voltadas ao ensino.

\begin{abstract}
A mesma aula de redação que focalize o processo de produção, e não apenas o produto-texto, pode incluir tecnologias que auxiliam o professor no acompanhamento do processo de escrita, seja em tempo real, seja por meio de registros detalhados, para muito além do que era usualmente feito, antes da existência de certos softwares. Do ponto de vista dos alunos, é possível ampliar as condições de interação com colegas, professor, além da pesquisa e da informação que alimentará uma melhor produção de texto. (RIBEIRO, 2016a, p. 102).
\end{abstract}

Assim, é com o intuito de refletir, partindo das condições atuais das escolas públicas brasileiras, como a aula de Língua Portuguesa nas turmas de alunos recém-alfabetizados pode ser desenvolvida com o uso de instrumentos digitais em práticas de produção de textos, utilizando ferramentas de processamento de texto, imagem e contando com o acesso a materiais armazenados no gerenciador de arquivos, como outras versões da mesma produção textual e figuras a serem inseridas na diagramação final de seu texto.

Nos próximos capítulos, iremos aprofundar nossa reflexão sobre o processo de hibridização entre a cultura manuscrita, tipográfica e digital na escola, os saberes envolvidos na produção de textos por alunos recém-alfabetizados e quais as reformulações na relação didática implicadas ao ensino do uso de ferramentas digitais na produção de texto nos anos iniciais do Ensino Fundamental. 


\section{A produção de texto na escola no Ciclo de Alfabetização: do papel para a tela}

Neste capítulo, vamos explorar alguns estudos que tratam das implicações do uso de tecnologias digitais no ensino do sistema de escrita e produção de textos. Diversos autores (COSCARELLI, 2011; FRADE, 2011a; RIBEIRO, 2016b; SOARES, 2002, 2003) salientam a necessidade de refletirmos quais são os novos desafios no ensino da leitura e da escrita em um contexto em que o uso de dispositivos eletrônicos nas práticas de leitura e escrita é cada vez mais difundido nas relações sociais.

É que estamos vivendo, hoje, a introdução, na sociedade, de novas e incipientes modalidades de práticas sociais de leitura e de escrita, propiciadas pelas recentes tecnologias de comunicação eletrônica - o computador, a rede (a web), a Internet. É, assim, um momento privilegiado para, na ocasião mesma em que essas novas práticas de leitura e de escrita estão sendo introduzidas, captar o estado ou condição que estão instituindo: um momento privilegiado para identificar se as práticas de leitura e de escrita digitais, o letramento na cibercultura, conduzem a um estado ou condição diferente daquele a que conduzem as práticas de leitura e de escrita quirográficas e tipográficas, o letramento na cultura do papel. (SOARES, 2002, p. 146).

Concordando com Soares (2002, p. 148), quando afirma que o termo letramento nomeia o estado ou a condição em que vivem e interagem as pessoas em sociedades nas quais a escrita está imbricada nas mais diversas relações interpessoais, é coerente que as tecnologias de escrita (suportes e riscadores), os instrumentos das práticas sociais de leitura e escrita, exerçam uma forte influência no estado ou condição de ser letrado. Assim, interessa-nos, em um primeiro momento, identificar as principais diferenças entre as práticas de leitura e escrita na cultura do papel daquelas da cultura da tela ${ }^{59}$ e em seguida nos debruçaremos acerca das especificidades que envolvem o processo de ensino da produção de textos por alunos recémalfabetizados. O referencial teórico evocado nos auxiliará a compreender as mudanças que estão ocorrendo e virão a ocorrer na natureza do letramento e, consequentemente, no ensino da produção escrita nos anos iniciais do Ensino Fundamental.

\footnotetext{
${ }^{59}$ Soares utiliza o termo "cultura da tela" ou "cibercultura" apoiada em Lévy (1999, p. 17), que toma cibercultura para designar "o conjunto de técnicas (materiais e intelectuais), de práticas, de atitudes, de modos de pensamento e de valores que se desenvolvem juntamente com o crescimento do ciberespaço". Segundo o mesmo autor, ciberespaço é "o novo meio de comunicação que surge da interconexão mundial dos computadores".
} 


\subsection{O espaço de escrita e os mecanismos de produção}

Na esteira da análise realizada por Soares (2002), ressaltaremos as características inerentes a cada uma das tecnologias a partir de dois elementos relevantes: i) o espaço de escrita e ii) os mecanismos de produção, reprodução e difusão da escrita.

O primeiro item, espaço de escrita, refere-se ao "campo físico e visual definido por uma determinada tecnologia de escrita" (BOLTER, 1991 apud SOARES, 2002, p. 149). É bastante marcante como os espaços de escrita foram transformados ao longo da história, desde tábuas de argila para inscrever a escrita cuneiforme, passando pela superfície interna do rolo de papiro até o códice, delimitando o espaço em materiais diversos até a superfície branca da página de papel, pautada manualmente pelos mestres-calígrafos, demarcando não só o espaço do texto, mas também o tamanho das letras (CAGLIARI, 1999; TANCK DE ESTRADA, 1988). Na contemporaneidade, o espaço privilegiado de escrita é a tela do computador e do celular multifuncional. Ao tratarmos do espaço de escrita, é importante retomarmos a definição do termo "suporte" dos gêneros textuais segundo Marcuschi:

O suporte firma ou apresenta o texto para que se torne acessível de um certo modo. $O$ suporte não deve ser confundido com o contexto nem com a situação, nem com o canal em si, nem com a natureza do serviço prestado. Contudo, o suporte não deixa de operar como um certo tipo de contexto ainda não bem compreendido. [...] A ideia central é que o suporte não é neutro e o gênero não fica indiferente a ele. (MARCUSCHI, 2003, p. 13).

O autor assinala que apesar de não dever ser confundido com o contexto comunicativo, o suporte não é neutro, pois sua materialidade deixa transparecer marcas nos modos de escrever e ler os textos. Assim, a relação entre o espaço físico e visual de escrita e as práticas de leitura é muito estreita, relacionando-se aos gêneros textuais desenvolvidos de acordo com as diferentes práticas de leitura e escrita de uma dada época. Na atualidade, observamos profundas modificações em relação à delimitação dos suportes em virtude da multifuncionalidade da tela dos dispositivos, conforme assinala Roger Chartier:

Dissociados dos suportes em que costumamos encontrá-los (o livro, o jornal, o periódico), os textos, de agora em diante, estariam fadados a uma existência 
eletrônica: compostos no computador ou numerizados, transmitidos por procedimentos teleinformáticos, eles alcançam um leitor, que os apreende num monitor. (CHARTIER, R., 1994, p. 185).

A alteração do espaço de leitura e escrita, ou seja, a transformação dos suportes, demanda novas técnicas intelectuais, o que implica alça-la ao status de "revolução dos suportes".

Essas mutações comandam, inevitável e imperativamente, novas maneiras de ler, novas relações com o escrito, novas técnicas intelectuais. Se as precedentes revoluções da leitura ocorreram em épocas nas quais as estruturas fundamentais do livro não mudavam, não é o que se dá no nosso mundo contemporâneo. A revolução iniciada é, antes de tudo, uma revolução dos suportes e das formas que transmitem o escrito. (CHARTIER, R., 1994, p. 190, grifos nossos).

De fato, alterações nas tecnologias de escrita produzem modificações profundas nos suportes e, consequentemente, no modo como as pessoas se relacionam com os textos. Roger Chartier ressalta que outra revolução dessa magnitude se deu apenas com o advento do formato do códice em lugar dos rolos de papiro ou pergaminho. A própria revolução da imprensa não promoveu tamanha mudança, pois ela nasce e opera na mesma lógica do códice.

A revolução do nosso presente é, com toda certeza, mais que a de Gutenberg. Ela não modifica apenas a técnica de reprodução do texto, mas também as próprias estruturas e formas do suporte que o comunica a seus leitores. O livro impresso tem sido, até hoje, o herdeiro do manuscrito: quanto à organização em cadernos, à hierarquia dos formatos, do libro da banco ao libellus; quanto, também, aos subsídios à leitura: concordâncias, índices, sumários etc. Com o monitor, que vem substituir o códice, a mudança é mais radical, posto que são os modos de organização, de estruturação, de consulta do suporte do escrito que se acham modificados. Uma revolução desse porte necessita, portanto, outros termos de comparação. (CHARTIER, R., 1994, p. 187, grifos nossos).

Analisando as possibilidades que o espaço de escrita oferece para as práticas de leitura e escrita, Soares aponta:

O espaço de escrita condiciona, sobretudo, as relações entre escritor e leitor, entre escritor e texto, entre leitor e texto. A extensa e contínua superfície do espaço de escrita no rolo de papiro ou pergaminho impunha uma escrita e uma leitura sem retornos ou retomadas. Já o texto nas páginas do códice tem limites claramente definidos, tanto a escrita quanto a leitura podem ser controladas por autor e leitor, permitindo releituras, retomadas, avanços, fácil localização de trechos ou partes; além disso, o códice torna evidente, materializando-a, a delimitação do texto, seu começo, 
sua progressão, seu fim, e cria a possibilidade de protocolos de leitura como a divisão do texto em partes, em capítulos, a apresentação de índice, sumário. (SOARES, 2002, p. 150).

No computador, o espaço de escrita é sempre delimitado pela tela. Quem escreve ou quem lê a escrita digital tem acesso, no mesmo dispositivo, a diversos tipos de conteúdo: arquivos em PDF, e-books, páginas de internet, páginas do editor de texto, entre outros. No entanto, a visualização se limita ao que é possível expor na tela, hierarquizando os outros conteúdos acessados em posições secundárias, que podem ser novamente retomados por meio de ícones, abas ou links. As práticas de leitura e escrita na tela são realizadas de forma multilinear, por meio do acionamento de links que vão apresentado conteúdos no espaço da tela sem que haja uma ordem predefinida.

Em síntese, a tela, como novo espaço de escrita, traz significativas mudanças nas formas de interação entre escritor e leitor, entre escritor e texto, entre leitor e texto e até mesmo, mais amplamente, entre o ser humano e o conhecimento. [...] a hipótese é de que essas mudanças tenham conseqüências sociais, cognitivas e discursivas, e estejam, assim, configurando um letramento digital, isto é, um certo estado ou condição que adquirem os que se apropriam da nova tecnologia digital e exercem práticas de leitura e de escrita na tela, diferente do estado ou condição - do letramento - dos que exercem práticas de leitura e de escrita no papel. (SOARES, 2002, p. 151).

Desse modo, ler e escrever na tela não é o mesmo que ler em um livro ou revista ou escrever visando a posterior circulação do conteúdo em tais suportes. Na tela, se passa do material para o imaterial, e as novas possibilidades de interação dos autores e leitores com o texto nesse novo espaço vai modificar profundamente os mecanismos de produção - segundo ponto abordado por Soares. Esses mecanismos têm, na tecnologia da impressão, a enformação da escrita, ou seja, a escrita é tida como algo estável e controlado. Estável porque o texto se torna reproduzível em cópias idênticas e controlado porque diversas instâncias intervêm em sua produção e a regulam. Assim, a imprensa alterou o estado ou condição dos que escrevem e leem, diferenciando de maneira muito substancial do letramento na cultura do manuscrito (SOARES, 2002, p. 153). A cultura do texto eletrônico/digital devolve a instabilidade ao texto ${ }^{60}$,

\footnotetext{
${ }^{60}$ De acordo com Roger Chartier (1994), a cultura do manuscrito propiciava essa instabilidade pelas modificações realizadas pelos copistas nos conventos, pelas glosas e anotações às margens dos textos. Tal instabilidade foi fortemente apagada com a popularização dos textos impressos.
} 
pois os leitores de textos digitais podem frequentemente interferir nele, acrescentar, alterar, definir seus próprios caminhos de leitura.

No mundo dos textos eletrônicos ou, mais exatamente, da representação eletrônica dos textos, duas sujeições, tidas até agora como imperativas, podem ser eliminadas. Primeira sujeição: a que limita rigorosamente as possíveis intervenções do leitor no livro impresso. Com o texto eletrônico, a coisa muda. Não somente o leitor pode submeter o texto a múltiplas operações (pode indexá-lo, colocar observações, copiá-lo, desmembrá-lo, recompô-lo, deslocá-lo etc.), mas pode ainda tornar-se seu co-autor. (CHARTIER, R., 1994, p. 192).

A fluidez dos conteúdos e seu rápido acesso convidam o leitor à sua livre recomposição e faz surgir a figura do lautor ${ }^{61}$, o leitor que atua como colaborador na construção dos sentidos do texto, não só para si, mas para todos que acessam o aquele determinado material transformando-o por seus comentários, curtidas, compartilhamentos e remixagens. Os conteúdos veiculados nas telas é também pouco controlado, pois é grande a liberdade de produção de textos, e os modos com que se regulam e controlam a qualidade e relevância do que é produzido e publicado se dá de forma reduzida. ${ }^{62}$ Com a ampla difusão de textos não regulados, é necessário que se desenvolvam novas competências para elencar informação pertinente e confiável e eliminar informação irrelevante e/ou não confiável. Ou seja, no processo de letramento, é necessário que se desenvolvam essas novas habilidades. Assim, há uma profunda reordenação das práticas de leitura e escrita, pois ocorrem alterações substanciais tanto nos meios de circulação quanto no espaço de escrita, e, desse modo, a formação de leitores e escritores na atualidade envolve a apropriação do manejo das ferramentas digitais para que eles se tornem aptos a desenvolver práticas de leitura e escrita nas telas dos diversos dispositivos digitais de seu espaço de criação, fixação e meio de circulação.

Abordando a questão do manejo de conteúdos diversos, precisamos refletir também sobre a capacidade de armazenamento e acesso a múltiplos textos, dos mais variados gêneros. Assim como na leitura, o processo de produção de textos sofre diferentes alterações, pois o

\footnotetext{
${ }^{61}$ Cf. ROJO, 2017.

${ }^{62}$ Os modelos de fórum e de leitores especialistas voluntários podem ser citados como iniciativas que operam em prol de uma regulação de conteúdos em alguns sites construídos em colaboração. Um exemplo interessante é a Wikipédia.
} 
escritor tem acesso a conteúdos diversos, com vistas à alimentação temática do texto que será produzido, o que gera modificações no processo de escrita. Na cultura do papel, o escritor precisa dispor de um amplo acervo pessoal de livros e revistas, de uma boa enciclopédia composta por uma grande quantidade de volumes ou se dirigir a uma biblioteca pública ${ }^{63}$. Dispondo de um computador, o escrevente pode recorrer a conteúdos previamente armazenados ou acessa-los no mesmo dispositivo em que é feita a escrita. Ao longo do processo de produção do texto, podem ser utilizadas cores e fontes tipográficas diversas, assim como balões de comentário. Esses recursos servem tanto para estabelecer marcações pessoais para posterior edição e revisão quanto para efeitos de diagramação e formatação, a fim de cumprir a função comunicativa do texto final. As versões do texto podem ser organizadas em pastas e salvas em disco rígido ou na computação em nuvem ${ }^{64}$.

Em suma, o estudo desenvolvido por Soares apregoa que diferentes tecnologias de escrita geram diferentes estados ou condições naqueles que fazem uso delas em suas práticas de leitura e de escrita: diferentes espaços de escrita e diferentes mecanismos de produção, reprodução e difusão da escrita resultam em diferentes letramentos (SOARES, 2002, p. 156). São novas maneiras de ler e escrever e, consequentemente, novos processos cognitivos, o que implica um novo estado ou condição de letramento para aqueles que exercem práticas de leitura e escrita na tela, condição diferente daquela circunscrita ao impresso e ao manuscrito.

\subsection{As diferentes facetas do ensino da escrita: da escrita de palavras à produção de textos}

Em virtude de nosso objetivo principal, ou seja, compreender o processo de aprendizagem da escrita de textos no computador por crianças recém-alfabetizadas,

\footnotetext{
${ }^{63}$ Aqui, caberia a noção de "grandes continentes", que na definição de Marcuschi se aplicaria a locais que servem de grandes postos de concentração de materiais impressos, como bibliotecas, livrarias, editoras e museus (MARCUSCHI, 2003, p. 19).

${ }^{64}$ Segundo a Wikipédia, o verbete "computação em nuvem" (em inglês, "cloud computing") é a disponibilidade sob demanda de recursos do sistema de computador, especialmente armazenamento de dados e capacidade de computação, sem o gerenciamento ativo direto do usuário.
} 
buscaremos pontuar quais são os saberes envolvidos no interior desse processo e de que forma o uso de diferentes artefatos da escrita pode ou não causar interferência.

Apoiando-nos em Soares, trataremos o ensino do sistema de escrita e produção de textos como um saber complexo e composto por diferentes facetas, considerando que cada uma delas guarda particularidades específicas e demanda diferentes estratégias de ensino, pois implica o desenvolvimento de diferentes capacidades metalinguísticas. A consciência metalinguística envolve níveis distintos, como a consciência fonológica, morfológica, sintática e textual, e é definida pela autora como:

[...] a capacidade de tomar a língua como objeto de análise, dissociando-a de seu uso habitual como meio de interação, é o que se denomina consciência metalinguística, capacidade essencial à aprendizagem da língua escrita. (SOARES, 2016, p. 125).

De acordo com ela, um aluno apenas alcança a condição de letrado quando é capaz de dominar cada uma dessas dimensões e articulá-las em práticas que envolvem leitura e produção de textos fluentes. Uma das dimensões, denominada faceta linguística, representa a "aprendizagem do sistema alfabético-ortográfico, que conduz à habilidade de leitura e de produção de palavras escritas" (SOARES, 2016, p. 36). Essa faceta envolve a compreensão das relações entre a pauta sonora e sua representação gráfica, identificar e registrar as letras que as representam e, por fim, compreender seu significado e seu sentido. No interior dessa faceta, desponta o desenvolvimento da consciência fonológica, que consiste em:

[...] compreensão das relações entre os sons da língua oral e sua representação na língua escrita particularmente por meio do desenvolvimento da habilidade de dissociar a cadeia sonora da fala de seu conteúdo semântico e da compreensão da possibilidade de segmentação da palavra falada em seus constituintes sonoros. (SOARES, 2016, p. 167).

A partir desse saber, torna-se necessário o domínio das convenções ortográficas que precisam ser aprendidas para se representar as palavras corretamente. Logo que o aluno se torna capaz de escrever palavras respeitando a ortografia da língua, ele pode ser considerado alfabetizado. 
[...] quando a criança se torna capaz de construir representações ortográficas das palavras, é que se pode considerar que ela realmente adquiriu habilidades de leitura e escrita de palavras, necessárias, ainda que não suficientes, para que alcance competência em leitura e produção fluentes de textos. (SOARES, 2016, p. 254).

Assim, essa primeira dimensão da aprendizagem da língua escrita - ou conforme denominada por Soares, a faceta linguística - parece não depender em grande parte do modo como as tecnologias de escrita são postas ao aluno. No entanto, a autora salienta que integrada a essa dimensão, há o aprendizado de uma técnica que "envolve, também, aprender a segurar o lápis, aprender que se escreve de cima para baixo, da esquerda para a direita; enfim envolve uma série de aspectos que chamo de técnicos" (SOARES, 2003, p. 15). Frade e Galvão assinalam a inter-relação entre os artefatos técnicos disponíveis e a aprendizagem de gestos necessários às práticas de escrita:

Na verdade, o uso de instrumentos nem sempre obedece a uma pedagogia idealizada, porque a sua materialidade (ou a sua ausência) obriga os sujeitos a determinados gestos. A tentativa de cientificizar o ensino da escrita na escola nem sempre foi possível, na medida em que a própria materialidade exige uma correspondência física e mental ajustada ao objeto. (FRADE; GALVÃO, 2016, p. 329, grifos nossos).

Dessa forma, ao lado das capacidades relacionadas de modo mais restrito à aprendizagem das relações grafema-fonema, estão outras que são mais ligadas a elementos técnicos da cultura escrita, ou seja, aos espaços de escrita e seus riscadores ou, ainda, como se grafa a língua escrita nos modos como ela circula nas efetivas práticas sociais. Consequentemente, a depender da tecnologia em uso em uma dada época, é necessário que os alunos desenvolvam capacidades específicas relacionadas aos elementos técnicos da cultura escrita de seu tempo. Por exemplo, vimos anteriormente que os inspetores de ensino no início do século XX rechaçavam o uso do lápis de ardósia para escrita na lousa individual no treino das primeiras letras, com a justificativa de que tornavam a mão da criança pesada, distanciando da escrita leve e delicada da pena metálica no papel branco (RAZZINI, 2008, p. 103).

Abordando de maneira específica as correlações entre a aprendizagem do sistema da língua escrita e o manejo de diferentes instrumentos, Baptista, Viana e Barbeiro (2011) assinalam que há uma complexa função neurológica que controla a aquisição e o desenvolvimento de competências de processamento cognitivo e de competências motoras. No 
que tange o processamento cognitivo, a escrita pressupõe o desenvolvimento de certas rotas neurais, mecanismos intelectuais e padrões de raciocínio, como as capacidades de inclusão de classe, a classificação múltipla, a seriação, a ordenação, a conservação e a orientação, bem como o domínio de certas convenções gráficas (orientação, direção da linha, entre outros saberes). Em relação às questões de motricidade, a escrita em papel pressupõe a flexibilidade da sequência de movimentos numa superfície plana, e para a escrita tanto em papel quanto em dispositivos com teclados é necessário que se ativem certos músculos que permitem organizar a musculatura (ombro, braço, mão) para o desenvolvimento da atividade (BATISTA; VIANA; BARBEIRO, 2011, p. 19).

Salientando a importância dos elementos técnicos da língua escrita em seu funcionamento, Frade (2011a, p. 64) assevera que "aparatos técnicos de escrita se cruzam com o aprendizado do sistema de notação, causando interferências mútuas". Desse modo, já nessa primeira dimensão da aprendizagem da língua escrita, é possível indicarmos que o uso de dispositivos digitais nas práticas de escrita provoca modificações importantes, pois em lugar de decorar e praticar o traçado das letras é necessário manejar bem o teclado.

Conforme salienta Soares (2016, p. 254) na citação acima, o aprendizado da escrita de palavras, que envolve o domínio da faceta linguística, constitui uma habilidade necessária, mas não suficiente para que se alcance a competência em leitura e escrita fluentes de textos. De acordo com a autora, a criança vai aprendendo a escrever ${ }^{65}$ palavras grafando-as passo a passo, mobilizando sua atenção de maneira mais exclusiva às associações entre fonemas e grafemas. Quando a cifração se torna rápida e correta, ou seja, quando a criança realiza representações ortográficas de palavras, ela se torna alfabética.

Essa progressão na leitura e na escrita pode ser explicada pelo modelo de dupla rota, que assume duas estratégias na leitura e na escrita: a rota sublexical (estratégia fonológica) ou a rota lexical (estratégia visual). Na rota sublexical, o escritor grafa as correspondências fonemagrafema e assim chega à palavra. Caso lance mão da rota lexical, o escritor ativa sua memória de

\footnotetext{
${ }^{65}$ Da mesma forma que o processo de escrita envolve o desenvolvimento da cifração rápida e ortográfica das palavras, na leitura, a decifração ganha rapidez e correção (SOARES, 2016, p. 254).
} 
longo prazo, a palavra como um todo, seu léxico ortográfico mental, sem necessidade de codificar fonema-grafema.

Nos escritores proficientes, as informações sobre a grafia das palavras são automaticamente ativadas e as duas rotas funcionam em paralelo, uma sustentando a outra. Essa adequação do modelo de dupla rota subordina-se a características das palavras a serem lidas ou escritas. Os principais efeitos de características das palavras sobre a leitura e a escrita identificados são: o efeito de lexicalidade, que incide na atividade de escrita quando a palavra já integra o conteúdo do léxico mental do escritor, assim, poderia ser grafada pelo uso da rota lexical (rota visual); o efeito de vizinhança, que exerce influência, sobre a leitura ou escrita de uma palavra por associação a palavras semelhantes arquivadas no léxico mental; o efeito de frequência, ou seja, palavras que são vistas com alta frequência passam a integrar o léxico ortográfico e semântico, sendo lidas e escritas predominantemente pela rota lexical, o que em geral possibilita mais rapidez e menos erros de leitura e escrita e, por fim, o efeito de regularidade que incide em virtude da ortografia do português brasileiro ser relativamente transparente, o que significa que as correspondências entre fonemas e grafemas não são totalmente regulares (biunívocas) pois há correspondências apenas parcialmente regulares (previsíveis pelo contexto linguístico) e correspondências irregulares (arbitrárias), que influenciam o reconhecimento e a grafia de palavras. São essas correspondências irregulares que criam o efeito de regularidade que, vencida a fase alfabética, manifesta-se na fase ortográfica, na leitura e sobretudo na escrita (SOARES, 2016, p. 285).

Assim, o quadro do modelo de dupla rota é configurado pelas características das palavras e as relações dessas duas rotas com o processo de aprendizagem da língua escrita.

[...] as crianças, no início da aprendizagem da língua escrita, quando ainda estão desenvolvendo a compreensão das correspondências entre fonemas e grafemas, privilegiam o uso da rota fonológica, também favorecida pela quase transparência da ortografia do português brasileiro. Com o avanço da escolarização e, consequentemente, a ampliação de seu léxico ortográfico, resultado de convívio progressivamente mais amplo e diversificado com textos que leem e escrevem, o uso da estratégia fonológica vai sendo igualado, e mesmo superado, pelo uso da rota lexical. (SOARES, 2016, p. 276). 
Embora a leitura e a escrita fluentes de palavras não signifiquem a plena inserção dos sujeitos em práticas de letramento, são habilidades necessárias para que a criança alcance competência em escrita, adquirindo "fluência e precisão, ainda que relativas, de modo que não se perca o fluxo do pensamento na produção de uma frase ou texto" (SOARES, 2016, p. 275).

No entanto, Soares destaca que o processo de letramento envolve diferentes dimensões, além da faceta linguística, e assinala a importância das demais envolvidas no processo, denominando-as faceta interativa e faceta sociocultural. De acordo com a autora (2016, p. 38), a faceta interativa tem como objeto de conhecimento o uso da língua escrita para a interação, ou seja, a compreensão e a produção de textos, que envolvem mais do que o domínio da dimensão linguística, envolvem elementos textuais e pragmáticos, que não são exclusivamente do domínio linguístico. Já a faceta sociocultural tem como objeto do conhecimento os usos e funções da língua escrita em diferentes contextos sociais e culturais e, desse modo, também opera com elementos não linguísticos. O desenvolvimento dessas facetas envolve o trabalho com outros diferentes níveis de consciência metalinguística, que abrangem tanto a já mencionada capacidade de ouvir a língua e analisar seus sons, relacionando-os com marcas gráficas - a consciência fonológica -, quanto a capacidade de refletir sobre a estrutura e a organização dos textos, compreendendo que cada um deles apresenta características sintáticas e contextuais.

Um dos níveis de consciência metalinguística, a consciência lexical ou morfológica, diz respeito à habilidade para segmentar a linguagem oral em palavras, considerando tanto aquelas com função semântica, ou seja, que possuem um significado independente do contexto (tais como os substantivos, adjetivos, verbos), quanto aquelas com função sintático-relacional, que adquirem significado apenas no interior de sentenças (como conjunções, preposições, artigos) (BARRERA; MALUF, 2003). Além de contribuir para o desenvolvimento da ortografia, o desenvolvimento da consciência morfológica por aprendizagem explícita contribui também para a leitura de palavras morfologicamente complexas, que por meio do reconhecimento de afixos da língua se torna mais fácil e rápida, pois pode ser feita não só fonologicamente, mas também morfologicamente. Assim, o conhecimento morfológico: 
Assume papel significativo no desenvolvimento da ortografia, da leitura de palavras, do vocabulário, da compreensão de textos quando se tornam mais numerosas e mais complexas as experiências e vivências da criança com a língua escrita. Neste momento, a relação entre consciência morfológica e desenvolvimento da leitura e da escrita se torna, por hipótese, recíproca: a leitura e a escrita ativam a consciência morfológica e esta, por sua vez, facilita aquelas. (SOARES, 2016, p. 157-158).

Já a consciência metassintática refere-se à habilidade para refletir e manipular mentalmente a estrutura gramatical das sentenças (BARRERA; MALUF, 2003). Despertar a consciência metassintática ou gramatical nos novos escritores significa desestruturar estruturas linguísticas que a criança já domina, internalizadas pelo processo de aquisição da língua oral. 0 desenvolvimento da consciência metassintática, assim como a metatextual, está muito relacionado à capacidade de compreensão.

Estudos têm demonstrado que a atenção dedicada à estruturação gramatical das sentenças é crucial para a compreensão do significado das mesmas. De acordo com Gombert e Colé (2000), a leitura em seus estágios iniciais, quando o processo de decodificação ainda não está automatizado, supõe, por parte do leitor, o controle consciente das estruturas sintáticas que levam à compreensão. Existe também considerável suporte empírico para a hipótese de que a criança utiliza seu conhecimento sintático e semântico para monitorar a compreensão do texto, através da identificação e auto-correção de erros gramaticais e/ou contextualmente inaceitáveis. (BARRERA; MALUF, 2003, p. 500).

Assim, após o domínio da aprendizagem inicial de leitura e escrita de palavras, as consciências morfológica e sintática se mostram fundamentais, pois "o aumento das experiências com a língua escrita possibilita à consciência sintática contribuir para a aprendizagem de princípios relevantes na escrita" (SOARES, 2016, p. 145).

A consciência pragmática focaliza a língua como forma de interação, promovendo a consciência das relações que existem entre o sistema linguístico e o contexto em que ele é usado, viabilizando o reconhecimento de traços textuais da intencionalidade do autor, da aceitabilidade de seu público leitor e da situação comunicativa na qual ele circula.

[...] a consciência pragmática é extremamente relevante para o desenvolvimento das habilidades de compreensão de texto e de produção textual, atividades que exigem a consideração da influência sobre o texto de fatores externos à língua. (SOARES, 2016, p. 136). 
De maneira semelhante, o desenvolvimento da consciência metatextual está intimamente relacionado à faceta interativa, pois promove a reflexão que acompanha, regula e controla a produção de textos em seus aspectos locais e globais, desenvolvendo estratégias de compreensão.

[...] cabe destacar, em relação à consciência metatextual, sua importância: de um lado, para compreender o processo de desenvolvimento das habilidades textuais nas crianças, de outro, e com base nessa compreensão, para configurar métodos que acompanhem e orientem a compreensão leitora e as habilidades de produção textual. (SOARES, 2016, p. 140).

Compreender o funcionamento da consciência metatextual é importante, por um lado, para entender o processo de desenvolvimento das habilidades textuais nas crianças e, por outro lado, para configurar métodos que acompanhem e orientem a compreensão leitora e as habilidades de produção textual.

Desse modo, Soares apregoa que o desenvolvimento da consciência fonológica e, no interior dela, da consciência fonêmica é o pilar do desenvolvimento da faceta linguística, ou seja, da aprendizagem inicial da língua escrita, a competência de ler e escrever palavras com fluidez. Já o desenvolvimento das competências morfológica, sintática, textual e pragmática é essencial para o desenvolvimento das facetas interativas e socioculturais envolvidas na aprendizagem da língua escrita, pois

[...] bons produtores de texto são capazes de escrever palavras não apenas corretamente, mas também de forma predominantemente automática; a produção de um texto deve demandar pouca atenção à escrita das palavras, a fim de que o autor possa concentrar-se nos processos de mais alto nível envolvidos na construção de textos bem estruturados, coerentes e coesos. (SOARES, 2016, p. 251, grifos nossos).

Desse modo, nossos dados nos permitirão observar como alunos recém-alfabetizados, em processo de automatização da escrita de palavras, operam com os diferentes níveis de consciência metalinguística quando colocados frente à tarefa de produzir textos. A seguir, discutiremos de maneira pormenorizada esses saberes, que emergem nos novos escritores na tarefa de produção textual. 


\subsubsection{O processo de produção de textos para alunos recém-alfabetizados}

Com o intuito de esmiuçar as especificidades dos saberes e habilidades envolvidos na aprendizagem da produção de textos, iniciaremos este tópico apresentando a proposta de Barbeiro e Pereira (2007), que propõem uma delimitação de competências para a compreensão dos processos subjacentes à prática de produção de textos. De acordo com os autores, são três grandes competências que precisam ser aprendidas pelos escritores, sendo duas delas, a competência gráfica e a ortográfica, paulatinamente automatizadas pelos escreventes. Já a terceira, denominada composicional, incide na forma de combinar expressões linguísticas para construir um texto. Esta última nunca é plenamente automatizada, pois envolve saberes diversos, de acordo com a situação comunicativa na qual o escritor se encontra. Em outras palavras, a divisão proposta pelos autores apregoa que o aluno precisa, em determinado momento, desempenhar de maneira automática as competências gráfica e ortográfica, sem que sejam necessários quaisquer processamentos ou decisões conscientes. Da mesma forma, Dolz, Gagnon e Decândio salientam que o gesto gráfico envolvido na prática de escrita induz o sistema sensório-motor em diversos níveis e leva tempo para ser automatizado pelos jovens escritores.

\footnotetext{
A coordenação óculo-manual, a grafomotricidade, o alinhamento de palavras e a organização da página. Embora esses aspectos sejam automatismos para o escritor expert, eles têm muita importância nas primeiras etapas de descoberta do sistema gráfico. Os variados suportes, as ferramentas de escrita, a força da mão, a precisão do gesto, a valorização do traço escrito, a educação do olho, o trabalho sobre a representação dos itinerários gráficos são aspectos a serem considerados nas primeiras aprendizagens gráficas. $O$ domínio da técnica de escrita é facilitado pela observação e pela realização de gestos elementares que contribuem para fixar, pouco a pouco, as regularidades da escrita. (DOLZ; GAGNON; DECÂNDIO, 2010, p. 21).
}

Dessa forma, a automatização dessas competências representa uma conquista importante na trajetória do aprendizado da língua escrita, pois após conquistá-la o jovem escritor poderá se dedicar de maneira mais exclusiva às tarefas voltadas ao desenvolvimento da competência compositiva, estritamente vinculada às dimensões sociais e interativas, que nortearão as escolhas linguísticas da produção textual. Esta última, ao contrário da gráfica e da 
ortográfica, nunca está plenamente automatizada, pois cada texto coloca novos desafios e apresenta alternativas diversas para sua construção.

A partir dessa caracterização, cabe considerarmos que as turmas finais do Ciclo de Alfabetização ${ }^{66}$ costumam ser encaradas pelos professores como turmas complexas, justamente por estarem em uma etapa marcada pelo incremento de novas competências relacionadas à leitura e escrita proficientes, ou seja, é uma etapa em que se espera, conforme preveem os currículos e demais documentos norteadores do ensino, que os alunos já tenham automatizado boa parte dos saberes envolvidos nas competências gráfica e ortográfica e estejam prontos para se engajarem de maneira mais qualitativa em atividades efetivas de produção e leitura de textos diversos.

De fato, a aprendizagem da escrita é reconhecidamente um processo complexo e gradual, inclusive quando abordamos a questão da aprendizagem da ortografia, que, ao longo do desenvolvimento de diferentes situações de produção textual às quais os alunos são colocados, exigirá o domínio de regularidades e a memorização de relações irregulares ${ }^{67}$, ampliando os efeitos de frequência e regularidade na escrita de palavras. A automatização da competência gráfica e o domínio das relações ortográficas mais frequentes - ou nos termos de Soares, o domínio da faceta linguística -, embora envolvam saberes específicos, não ocorrem de modo isolado das outras facetas, dos outros saberes. Conforme salienta Cagliari (2010, p. 107), "as crianças ainda em fase de alfabetização, demonstram capacidade para produzir textos", e, dessa forma, somente ao serem frequentemente colocados no papel de leitores e produtores de textos, os novos escritores conseguirão desenvolver as competências necessárias para conquistar os automatismos e a fluidez desejados.

A aprendizagem inicial da língua escrita, embora entendida e tratada como fenômeno multifacetado, deve ser desenvolvida em sua inteireza, como um todo, por que essa é a natureza real dos atos de ler e escrever, em que a complexa interação entre as práticas sociais da língua escrita e aquele que lê ou escreve pressupõe o exercício simultâneo de muitas e diferenciadas competências. É o que se tem denominado alfabetizar letrando. (SOARES, 2016, p. 35, grifos nossos).

\footnotetext{
${ }^{66}$ Referimo-nos aos 3o anos do Ensino Fundamental, compreendendo o Ciclo de Alfabetização conforme era proposto em ocasião da geração dos dados - 2016 -, sendo composto pelos 1ㅇ, 2ㅇe 3음 anos, ou seja, dos 6 aos 8 anos de idade.

${ }^{67}$ Cf. MORAIS, 2002.
} 
Frente ao repertório teórico exposto até o momento, é necessário ter ciência de que as práticas de leitura e especialmente de escrita nos anos iniciais precisam abordar gêneros que possibilitem ao aluno utilizar os conhecimentos já construídos e desenvolver, pouco a pouco, outros necessários à sua inserção plena no mundo letrado. A Base Nacional Comum Curricular, embora saliente que os dois anos iniciais ${ }^{68}$ têm como foco da ação pedagógica a alfabetização ou seja, nos termos de Soares (2016), a faceta linguística, ou, nos termos de Barbeiro e Pereira (2007), as competências gráficas e ortográficas -, salienta também a importância do desenvolvimento de práticas de leitura e produção textual, observando de maneira cuidadosa quais serão os gêneros abordados nessa etapa da escolarização.

[...] os gêneros propostos para leitura/escuta e produção oral, escrita e multissemiótica, nos primeiros anos iniciais, serão mais simples, tais como listas (de chamada, de ingredientes, de compras), bilhetes, convites, fotolegenda, manchetes e lides, listas de regras da turma etc., pois favorecem um foco maior na grafia, complexificando-se conforme se avança nos anos iniciais. Nesse sentido, ganha destaque o campo da vida cotidiana, em que circulam gêneros mais familiares aos alunos, como as cantigas de roda, as receitas, as regras de jogo etc. (BRASIL, 2018, p. 91).

Essa atenção aos gêneros abordados nos anos iniciais deve-se ao fato de que o escritor recém-alfabetizado precisa colocar em funcionamento paralelo questões relacionadas a diferentes problemas enfrentados durante o processo de escrita, sendo-Ihe imposto simultaneamente e de modo concatenado várias questões para serem resolvidas. Conforme assinalam Calil e Pereira (2018, p. 92), quando colocados no papel de produtores de texto, os novos escritores irão lidar tanto com o sistema notacional, que envolve as representações grafofônicas com suas dimensões gráficas e ortográficas, ainda não automatizadas, quanto com o próprio processo de geração do texto e transcrição, que exige conhecimentos semânticos, sintáticos, morfológicos, de pontuação e acentuação, saberes vinculados ao encadeamento entre palavras e frases que irão compor o texto final.

\footnotetext{
${ }^{68}$ Diferente das diretrizes da Secretaria Municipal de Educação de São Paulo (SÃO PAULO, 2016) que fixa os três primeiros anos como integrantes do Ciclo de Alfabetização, a BNCC estabelece apenas os dois primeiros anos do Ensino Fundamental como integrantes do Ciclo de Alfabetização.
} 
O aprendiz-escrevente, enquanto produtor de texto, recorre simultaneamente a informações múltiplas relacionadas ao conteúdo, a forma e a função daquilo que está sendo escrito, buscando resolver problemas diversos e heterogêneos. Sua ação como escrevente está delimitada por seus conhecimentos linguísticos e por suas capacidades cognitivas, como por exemplo, a memória de longo prazo e a memória de trabalho (KELLOGG, 2001; MCCUTCHEN, 2000; FAYOL; MIRET, 2005), ativadas durante o processo escritural. (CALIL; PEREIRA, 2018, p. 92).

Desse modo, o escritor em transição, ou seja, aquele que ainda não automatizou os gestos gráficos e um conjunto razoável de saberes ortográficos, precisa, ao mesmo tempo, articular saberes de duas naturezas, conforme explicitado no quadro abaixo:

Quadro 1 - Relação de saberes colocados em funcionamento na prática de produção de textos

\begin{tabular}{|c|l|}
\hline $\begin{array}{c}\text { Saberes relacionados ao } \\
\text { subsistema da escrita/ } \\
\text { sistema notacional }\end{array}$ & $\begin{array}{l}\text { - representações grafofônicas } \\
\text { - distinções gráficas e ortográficas }\end{array}$ \\
\hline $\begin{array}{c}\text { Saberes relacionones entre regras, normas e irregularidades ao } \\
\text { processo de geração do } \\
\text { texto (textualização) }\end{array}$ & \begin{tabular}{l} 
- aspectos semânticos, sintáticos e morfológicos \\
\hline
\end{tabular}
\end{tabular}

Fonte: Adaptado de Calil e Pereira (2018, p. 92).

Em relação aos dois tipos de saberes apresentados no quadro, aqueles que estão elencados na primeira linha são os automatizáveis; já os elencados na segunda linha estão relacionados ao processo de produção de textos, ou seja, demandam mais decisões por parte do escritor. Ao analisarmos os saberes que se interpõem, é possível visualizarmos como são diversos os problemas enfrentados pelos escritores novatos.

Abordando de maneira mais específica as questões relacionadas à ortografia, podemos salientar que os desafios que se colocam no momento da produção escrita podem ser de duas ordens. A primeira, lexical, se refere aos problemas relacionados ao modo como a palavra é normatizada - dicionarizada -, sem nenhum vínculo com o contexto no qual ela se insere; a segunda se refere a questões gramaticais, ou seja, aos saberes vinculados às variações de uma palavra em relação ao seu contexto de ocorrência. 
Quadro 2 - Problemas ortográficos lexicais e gramaticais

\begin{tabular}{|l|l|}
\hline \multicolumn{1}{|c|}{ Problemas ortográficos lexicais } & \multicolumn{1}{|c|}{ Problemas ortográficos gramaticais } \\
\hline - apoio na oralidade & - marcas de gênero masculino e feminino \\
- representações homofônicas & - concordância nominal \\
- M antes de B/P & - concordância verbal \\
- troca surda/sonora & - classe gramatical \\
- nasalização & - derivações morfológicas \\
- acentuação & - variações verbais (conjugação, tempo e \\
- segmentação & pessoa verbal) \\
- translineação (separar a palavra ao final da & - uso de letra maiúscula associado ao sistema \\
\hline linha) & de pontuação \\
\hline
\end{tabular}

Fonte: Adaptado de Calil e Pereira (2018, p. 99).

Em suma, os autores salientam que os problemas ortográficos de alunos nessa fase do processo de alfabetização são muitos e diversos e destacam aqueles relacionados às questões homofônicas como os mais frequentes.

Feitas as devidas considerações acerca do desenvolvimento da competência gráfica e ortográfica, nos ocuparemos de maneira específica com a competência compositiva. Ao contrário da gráfica e da ortográfica, nas quais os escritores precisam trabalhar com regras predefinidas, a compositiva apresenta um campo aberto para a tomada de decisões por parte do escritor.

A escrita exige a capacidade de seleccionar e combinar as expressões linguísticas, organizando-as numa unidade de nível superior, para construir uma representação do conhecimento, correspondente aos conteúdos que se quer expressar. A escrita encontra no texto a forma mais relevante de representação do conhecimento. (BARBEIRO; PEREIRA, 2007, p. 15).

Em sua revisão sobre os estudos teóricos da produção de texto, Jolibert (1994) aponta três grandes operações envolvidas nesse processo. A primeira é o planejamento textual, que incide em tornar claro a quem o texto se destina e qual o objetivo do autor. É também na operação de planejar que o escrevente precisa delimitar qual "forma final" o texto assumirá. São decisões que devem ser tomadas em momento anterior à própria escrita do texto, ativando

\footnotetext{
${ }^{69}$ Relação entre duas ou mais palavras que, sendo diversas no significado e na grafia, são pronunciadas de modo idêntico. A relação homofônica entre os grafemas $\langle\mathrm{c}\rangle,\langle c ̧\rangle,\langle\mathrm{s}\rangle$, o dígrafo SS e o fonema /s/.
} 
conteúdos e decidindo sobre sua integração ou não ao produto textual. Implica pensar e organizar o texto, sendo "mobilizada para estabelecer objetivos e antecipar efeitos, para activar e selecionar conteúdos, para organizar a informação em ligação à estrutura do texto, para programar a própria realização da tarefa" (BARBEIRO; PEREIRA, 2017, p. 18), ou seja, ensinar o aluno a planificar implica reflexões voltadas à vertente metatextual.

A segunda operação é chamada de textualização, que consiste nas ações para linearizar o texto, ou seja, a progressão e conservação de informação durante o texto, trabalhando com elementos que garantam conexão, segmentação, tempos verbais, uso de conectivos e pontuação em suas funções textuais. Em outras palavras, é quando o escritor elege a informação específica e precisa articular os diferentes conteúdos dando-lhes uma expressão linguística para figurarem no texto, respeitando as exigências de coesão e coerência. A textualização é o aparecimento das expressões linguísticas que organizadas em frases, parágrafos ou seções formam o texto. À medida que textualizamos, é necessário explicitar o conteúdo, tornando acessível a informação ao leitor, ao mesmo tempo em que se realiza a formulação linguística.

A terceira operação consiste na revisão dos textos (ou releitura), que pode ocorrer durante a produção ou ao seu término. Nessa operação, o escritor precisa se distanciar da sua produção escrita de modo a realizar os ajustes necessários. Compreende um retorno do produtor ao seu texto com o intuito de aprimorá-lo em diferentes aspectos (ortográfico, escolhas lexicais, utilização dos organizadores textuais, entre outros). O processo de revisão se dá por meio da leitura, avaliação e eventual correção ou reformulação do que foi escrito e pode ocorrer em diferentes momentos do processo de produção textual, no entanto, destaca-se o papel da revisão final.

Assim, no desenvolvimento dessas operações, o escritor precisa decidir sobre questões em dois níveis: o global, que envolve a organização das grandes unidades do texto (macroestrutura), e o local, que envolve a seleção das unidades menores (microestrutura). As operações de gestão em nível global estão mais relacionadas às operações de planejamento e revisão. Já a operação de textualização age tanto no nível global quanto no nível local, na medida em que precisa garantir a coesão, conexão/segmentação e modalização, que envolvem 
decisões do encadeamento textual, a combinação de expressões linguísticas (microestrutura) (SCHNEUWLY apud ROJO, 2008, p. 196).

Durante o processo de escrita, quem escreve tem ao seu alcance a possibilidade de tomar decisões nesses níveis [global e específico]: desde a forma como vai organizar a informação no texto, segundo determinada estratégia de desenvolvimento, até a escolha entre duas ou mais palavras ou expressões que pode utilizar numa determinada passagem do texto. (BARBEIRO; PEREIRA, 2007, p. 16).

Como o ensino dessa competência complexa e, de maneira mais específica, dessas três grandes operações envolvidas na produção de textos ocorre na escola? Revisitando as perspectivas teóricas que guiaram o ensino da produção de texto nas últimas décadas, Rojo (2008) aponta duas principais: a cognitiva, ancorada especialmente no trabalho de Hayes e Flower (1980), e a enunciativa, calcada na proposta de Schneuwly (1988).

A perspectiva cognitiva, elaborada a partir de uma crítica aos modelos divulgados nas décadas de 1960 e 1970, propõe um modelo recursivo, ou seja, planejar, produzir e revisar são encarados como subprocessos que interagem uns com os outros ao longo de todo o processo global de composição. Nessa proposta,

[...] a produção de textos é vista como um conjunto (hierarquizado) de comportamentos, regidos por processos cognitivos gerados por esquemas ou conhecimentos armazenados na memória e ativados pelo contexto (de tarefa). Portanto, um processo ensimesmado (na MLP ${ }^{70}$ do escrevente), em que o único papel do contexto social de ocorrência - no caso, um contexto bastante instrucional e escolar - seria o de fornecer informações ou inputs, capazes de ativar esquemas cognitivos e lógicos pré-existentes. (ROJO, 2008, p. 193).

Já a perspectiva enunciativa tem foco na situação de comunicação, que constituiria uma base de orientação na qual o escritor é inserido. Essa base deve ser composta pelos parâmetros fundamentais da situação de produção, que serão representados pelo enunciador, seu próprio lugar social como autor, suas relações com seu(s) interlocutor(es) e o objetivo da enunciação.

Contrastando os dois modelos, a autora elenca três principais diferenças entre eles. Em primeiro lugar, as formas (composicionais, linguísticas e semânticas) da linguagem e do discurso (enunciado) são decisivamente enfatizadas na proposta enunciativa, ao invés de formas

\footnotetext{
${ }^{70}$ Memória de longo prazo.
} 
cognitivas outras, que seriam traduzidas em linguagem, ou seja, a proposta enunciativa desloca o foco da cognição individual para a interação social. O segundo ponto é que a perspectiva enunciativa parte da situação comunicativa, que se torna a base de orientação de toda a proposta. Por fim, ela salienta que a proposta de Schneuwly, por atribuir maior relevância à situação comunicativa, é capaz de recobrir múltiplas situações de produção de textos, inclusive a escolar e a acadêmica.

Abordando de maneira mais específica como cada um desses modelos repercute no ensino da produção de textos na escola, Rojo (2008) destaca que a grande crítica sobre o modelo cognitivo é que ele opera sobre um processo conformado na memória de longo prazo do escrevente. Assim, as questões de aprendizagem da língua escrita estão fora de questão. Nesse caso, caberia à escola simplesmente ativar esses esquemas cognitivos e lógicos por meio de propostas de tarefas, como planejar, revisar e editar.

Com foco no processo de produção de textos por alunos nos anos iniciais e apoiada em uma teoria da enunciação, Smolka coaduna com a necessidade da adoção de práticas que sejam assentadas em situações contextualizadas de interlocução, que promovam a construção do sentido.

\footnotetext{
A alfabetização implica, desde sua gênese, a constituição do sentido. Desse modo, implica, mais profundamente, uma forma de interação com o outro pelo trabalho de escritura - para quem eu escrevo o que escrevo e por quê? A criança pode escrever para si mesma, palavras soltas, tipo lista, para não esquecer; tipo repertório, para organizar o que já sabe. Pode escrever ou tentar escrever um texto, mesmo fragmentado, para registrar, narrar, dizer... Mas essa escrita precisa ser sempre permeada por um sentido, por um desejo, e implica ou pressupõe, sempre um interlocutor. (SMOLKA, 2001, p. 69).
}

No processo de aprendizagem da escrita, Smolka aponta que a escrita de palavras soltas ou ditadas pelos adultos apresentam, evidentemente, maior correspondência qualitativa nas relações fonografêmicas. No entanto, ao começarem a escrever o que querem contar, explicar ou narrar, as crianças escrevem fragmentos de seu discurso interior, desvelando toda uma multiplicidade de saberes colocados em jogo e esquemas que estão sendo formulados e testados. 
A escritura adquire novas características: o ritmo, a entonação, a ênfase, as rupturas, a fluência, as contrações, as inferências... também são marcados na escritura inicial de modo peculiar. E na medida em que a escritura passa pelo "discurso anterior", ela começa a revelar também suas "marcas" do discurso social internalizado: suas normas, suas formas, sua legitimidade e aceitabilidade (O que "é dito?", O que é "possível" dizer? O que se pode ou se deve dizer? Como? Quando? Onde? Por quê?). (SMOLKA, 2001, p. 76).

Assim, com o intuito de desvelarmos mais aspectos do modelo enunciativo de Schneuwly (1988 apud ROJO, 2008), apresentaremos a proposta de Dolz, Gagnon e Decândio (2010), que desdobram em cinco as três principais operações envolvidas na produção de textos, de modo a enfatizar a situação comunicativa colocada ao aluno, envolvendo o escrevente em um contexto mais próximo das práticas comunicativas a serem desenvolvidas. Na proposta dos autores, a primeira operação consiste justamente em contextualizar o escrevente na situação de comunicação, de modo que ele possa interpretá-la e consiga realizar um julgamento geral para o conjunto do texto adequado à situação comunicativa. A segunda operação envolve a seleção dos conteúdos temáticos, visando a pertinência interna por meio do equilíbrio entre a apresentação de novas informações e a repetição de outras, de modo a garantir a progressão temática sem perder o fio condutor.

As operações de planificar e textualizar, que correspondem à terceira e quarta operações, se desenvolvem sob a dependência das duas instâncias anteriores. Planificar envolve organizar os conteúdos em uma ordem e hierarquia particulares, de acordo com a situação comunicativa proposta. Caudatária da mesma acepção teórica, Cardoso assinala:

As operações cognitivo-linguísticas desencadeadas na produção de um texto, seja ele oral ou escrito, devem tomar uma forma "linear" e dependente do tempo: devem se materializar em unidades linguísticas e, a cada momento, só uma informação pode ser emitida. (CARDOSO, 2008, p. 113).

A materialização a qual se refere a autora é o que chamamos de textualização, ou seja, é ação de aplicar e linearizar o conjunto de marcas linguísticas que constituirão o texto. No interior desse processo, temos os sinais de pontuação, os parágrafos e os organizadores textuais constituindo as marcas linguísticas que atuam na segmentação e conexão entre as partes do texto. 
As operações de "conexão/segmentação", por um lado, "pontuam" o discurso, dividindo-o em partes e, ao mesmo tempo, funcionando como um "cimento" que rejunta as unidades atomizadas resultantes da referenciação; por outro lado, articulam essas unidades ao contexto. (CARDOSO, 2008, p. 114).

De maneira concomitante, é necessário que o escritor garanta a coesão nominal e verbal do texto, de modo a assegurar as relações entre as frases por meio de um conjunto de marcadores coesivos, como o uso de pronomes e tempos verbais.

As operações de coesão compõem cadeias de "coesão nominal" e de "coesão verbal". As primeiras se relevam pelo uso de substantivos, pronomes e processos de sinonímia, antonímia, metonímia, metáfora, etc., para introduzir e retomar elementos no texto. As de "coesão verbal", pela sinalização de tempos, modos e aspectos feita pelas verbais. (CARDOSO, 2008, p. 114).

A quinta operação implica o retorno do produtor ao seu texto, distanciando-se do papel de escrevente e lançando um olhar crítico sobre sua própria produção. Assim, envolve ações como reler, revisar, editar e, por fim, reescrever, sempre com o intuito de intervir no produto escrito de forma a melhorá-lo, com vistas ao seu objetivo inicial.

A revisão é marcada sobretudo pela reflexão em relação ao texto produzido. Esta dimensão de reflexão acerca do que se escreveu deve ser aproveitada para tomar decisões respeitantes à correcção e reformulação do texto. (BARBEIRO; PEREIRA, 2017, p. 19).

O estudo desenvolvido por Pécora (1977 apud PIETRI, 2007) assinala de maneira bastante pontual o que Rojo (2008) salienta ao contrastar as vertentes cognitiva e enunciativa do ensino da produção de textos na escola. O autor tem como corpus de análise o outro extremo da escolarização: aqui, abordamos as práticas iniciais, e Pécora se debruça sobre a redação de vestibulandos. Em sua análise, atesta que os erros cometidos pelos alunos não são decorrentes de incapacidades linguísticas dos indivíduos, mas resultam dos modos como a produção de textos foi desenvolvida na escola: descolada das suas situações de produção e, ainda, de maneira assistemática, ou seja, se apoiando mais nas capacidades individuais do que na sistematização do ensino de recursos linguísticos para instrumentalizar a escrita dos alunos ao longo de sua vida escolar. Assim, apregoamos que as práticas de escrita na escola estejam fundadas em uma perspectiva enunciativa, tal qual descrevemos acima, por acreditarmos que 
as produções de texto na escola possam ocorrer de modo contextualizado e significativo para os jovens escritores, com a utilização dos diversos instrumentos de escrita que são manejados na sociedade, desde a aprendizagem das primeiras letras.

\subsection{Produzindo textos na tela}

Apesar de alguns autores utilizarem o conceito "alfabetização digital", Collelo, apoiada em Emília Ferreiro e outros estudos que defendem a relação recíproca entre a escrita e a tecnologia (LUIZE, 2007; MOLINARI; FERREIRO, 2013; TEBEROSKY, 2004), o rechaça por designar algo à parte da alfabetização tradicional. De acordo com a autora, ao assumirmos que há uma alfabetização digital sustentaríamos iniciativas centradas na aprendizagem de técnicas computacionais, focadas em preparar o aluno para um "uso do instrumental tecnológico independente da língua" (COLLELO, 2016, p. 8). Para ela, é necessário defender a relação recíproca entre escrita e tecnologia, assumindo que elas se transformam mutuamente. Assim, o computador configura-se como mais um recurso no processo de aprendizagem da língua escrita na medida em que pode ampliar e intensificar os modos pelos quais as pessoas interagem socialmente.

[...] seja no que diz respeito à língua como estratégia do dizer, seja no que toca à tecnologia enquanto recurso do como ou do onde dizer, ou, ainda no que se refere à alfabetização como propósito educativo, o que está em pauta é a participação de práticas sociais através da conquista de um modo de ser e de se relacionar com a cultura escrita e tecnológica. Como isso ocorre de modo integrado, não faz sentido distinguir alfabetização e alfabetização digital; melhor seria defender a alfabetização compatível com o nosso tempo e lugar. (COLLELO, 2016, p. 10).

Concordando com as colocações acima, Coscarelli destaca que os computadores devem ser integrados como um recurso a mais no cotidiano das aulas das escolas brasileiras, refutando a ideia de "aula de informática". Para a autora, os dispositivos digitais devem servir como ferramentas que ajudem a "integrar e reunir as diversas áreas do conhecimento, em um determinado projeto" (COSCARELLI, 2011, p. 32). No que toca de maneira mais específica as práticas de leitura e escrita, salienta que devido ao grande incremento de textos e mídias que 
circulam em meios digitais e em virtude do aumento do uso do computador como fonte de informação, é fundamental que os alunos acessem e interajam com textos digitais diversos para serem considerados letrados. É necessário que na esfera da alfabetização em seu sentido mais stricto - em outras palavras, em sua faceta linguística (SOARES, 1985, 2016) - ou no que toca a dimensão gráfica e ortográfica (BATISTA; VIANA; BARBEIRO, 2011) ocorram algumas adequações para que os alunos aprendam a escrever nos suportes mais comuns do mundo do estudo e do trabalho. Coscarelli nos convida à seguinte reflexão sobre os objetos de ensino em alfabetização:

Se antes era importante saber separar as palavras em sílabas, hoje, quem digita o texto não precisa se preocupar em partir as palavras para alinhar o texto, pois o computador faz isso automaticamente. Se antes era preciso saber escrever com letra cursiva, de preferência legível e bonita, agora é preciso saber digitar, é preciso conhecer as fontes disponíveis no computador e como usá-las. Ainda não precisamos trocar o lápis e a caneta pelo teclado, mas devemos aceitar essa troca como algo previsto para um futuro próximo. (COSCARELLI, 2011, p. 29).

A autora ainda salienta que aprender a ler e interpretar os diversos ícones que integram as diferentes ferramentas, como o navegador e o editor de textos, é na atualidade uma questão importante a ser ensinada logo nos anos iniciais.

Ao abordar a aprendizagem da grafia das letras, objeto de ensino central nos anos iniciais, Frade (2011a) tece relevantes considerações acerca de quando o escritor novato dispõe de dispositivos digitais para realizar sua produção escrita. Em primeiro lugar, a autora destaca que ao cessar o trabalho de traçar as letras, desafios cognitivos de outras ordens são lançados. Essa estratégia já é há algum tempo utilizada por professoras alfabetizadoras, que empregam um recurso denominado "letras soltas" ou "letras móveis", cujo material é formado por um conjunto de letras confeccionadas em papel ou plástico e a tarefa consiste em disponibilizá-lo ao aluno, ou a uma dupla de alunos, sob a consigna de formar palavras ou pequenos textos. Nessa proposta, os alunos estão desobrigados da tarefa de traçar letras e podem se concentrar na combinação qualitativa delas. No caso da utilização do teclado, podemos pensar em um efeito semelhante.

Do ponto de vista cognitivo, quando o aprendiz precisa pensar sobre qual letra representa um segmento sonoro e ainda dar conta de seu traçado, para inscrevê-la 
num suporte, as possibilidades de acúmulo de duas tarefas correlatas e, ao mesmo tempo, separadas podem trazer desafios cognitivos duplos para a alfabetização: saber, ao mesmo tempo, o que são letras, como grafá-las e ainda saber o que representam como sistema. (FRADE, 2011a, p. 70).

Desse modo, o uso do teclado na tela ou como um dispositivo periférico pode levar o escrevente a novas experimentações, uma vez que não precisa se preocupar com a grafia das letras e pode contar ainda com todo o conjunto das letras do alfabeto à sua frente, sem precisar recorrer a outra fonte para consultá-lo. No entanto, ao elencarmos os pontos acima não sugerimos que sejam implementadas aulas de digitação, do modo como foi feito com o ensino da caligrafia há pouco mais de um século atrás.

Trata-se, primeiro, de "inscrever" e, junto, apropriar-se da mecânica do instrumento. 0 alfabetizado que aprende a digitar é diferente do aprendiz das primeiras letras (e dos primeiros textos!) que digita enquanto aprende a registrar um sistema. (FRADE, 2011a, p. 73).

Embora dispense os aprendizes da tarefa de grafar letras, o uso dos novos artefatos acarreta todo um novo conjunto de saberes que, assim como a competência gráfica, precisam ser aprendidos e automatizados para que os processos de produção escrita se desenvolvam em crescente fluidez e qualidade. Em estudo recente, acompanhando o trabalho de produção de textos desenvolvidos em computador, observamos novas habilidades que precisam ser desenvolvidas, como conhecer e utilizar os diferentes caracteres do teclado, mover o cursor para ajustar a diagramação do texto e lidar com teclas que apresentam mais de um caractere. Assim, destacamos que:

\footnotetext{
A inserção desse instrumento articulou, ao já tradicional ensino da produção textual, outros saberes que passaram a compor o escopo da aula de produção de textos, como, por exemplo, o uso adequado do teclado e funcionalidades do editor de texto que compreendem, no conjunto de práticas decorrentes do uso das tecnologias da informação e comunicação, saberes cada vez mais diversificados, mais numerosos e recentes. (JORDÃO; NONATO, 2018, p. 226).
}

Feitas as considerações mais gerais acerca do domínio do teclado - artefato básico, mas muito longe de ser o único -, consideramos algumas das modificações que a escrita em tela acarreta na vida dos novos escritores. A seguir, iremos abordar como as propostas de produção textual podem ser reconfiguradas com esses novos instrumentos, pois já vimos que, para além 
do domínio da técnica, ou seja, a apropriação de uma tecnologia, é necessário que ocorra o efetivo exercício das práticas de escrita que circulam no meio digital (FRADE, 2011a; SOARES, 2002).

Em relação à produção de textos escritos, o que podemos esperar da utilização do computador pelos alunos? Tavares e Barbeiro (2011) trabalham com as potencialidades do uso do computador na produção escrita dos alunos a partir de três vertentes: o processo de escrita, o produto escrito e a participação em uma comunidade em rede. A Figura 1 abaixo exemplifica a proposta dos autores.

Figura 1 - Os diferentes papéis do computador na produção de textos

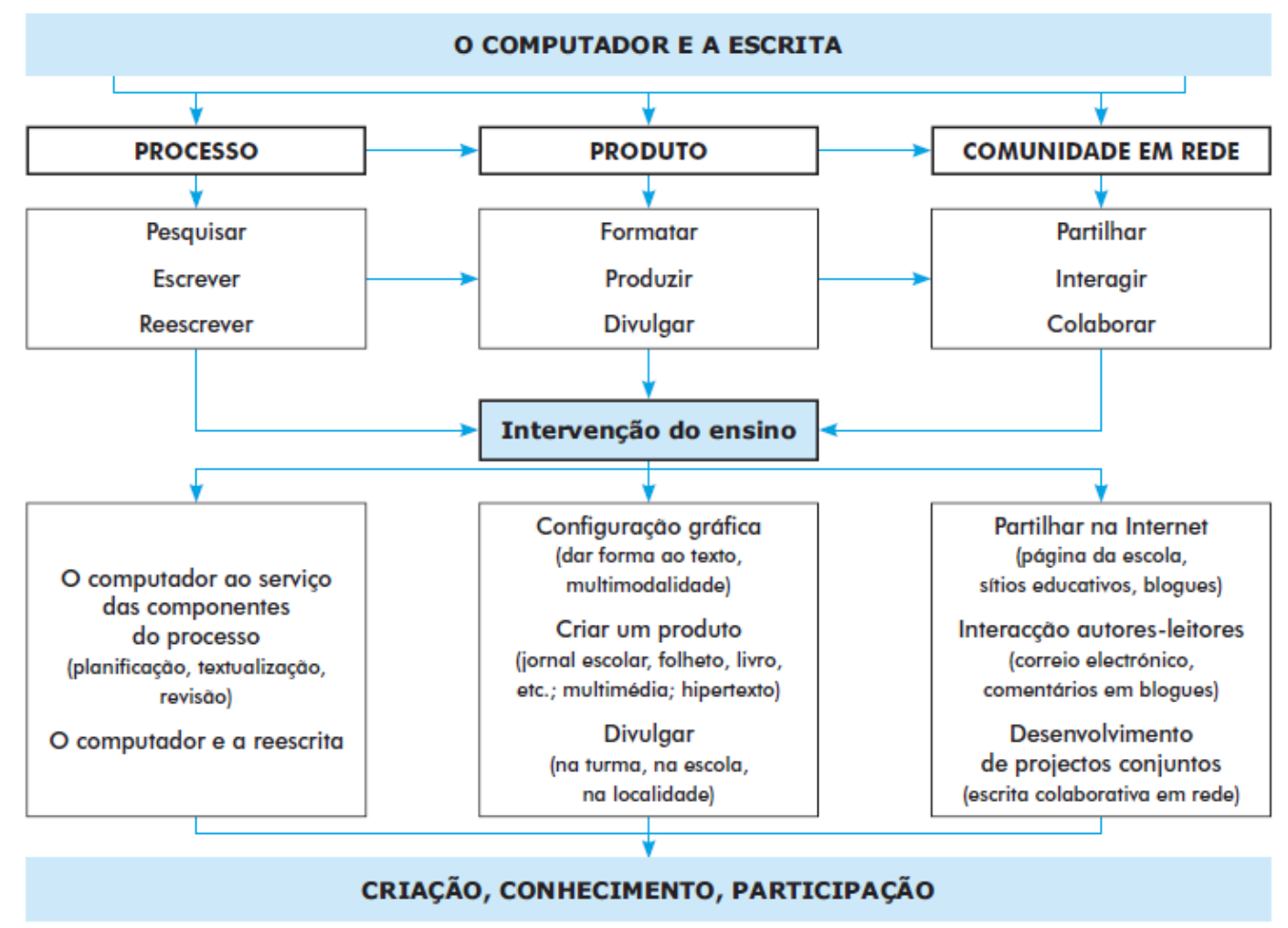

Fonte: Tavares e Barbeiro, 2011, p.58.

As colunas "Processo" e "Produto" estão relacionadas diretamente à utilização do computador como instrumento de escrita. Assim, as potencialidades do computador estão associadas ao processo de escrita - ou seja, ao modo como o ato de produzir um texto pode ser realizado - e, consequentemente, ao produto fruto desse processo - ou seja, a configuração 
gráfica que o texto escrito pode representar. A última coluna, Comunidade em Rede, incide na utilização do computador como instrumento de comunicação. Essa dimensão está intimamente relacionada ao uso da internet para a divulgação e o consumo de textos, promovendo uma interação autor-texto-leitor/consumidor muito específica da atualidade. Neste estudo, problematizamos apenas as operações envolvidas nas colunas "processo" e "produto", em virtude da proposta implementada na geração dos dados.

Considerando que o processo de escrita é marcado por formulações e reformulações, avanços e recuos, Tavares e Barbeiro (2011, p. 59) consideram que o computador, tomado enquanto instrumento de escrita, apresenta vantagens para a execução dos processos de planejamento, textualização e revisão. No que toca a operação de planejamento, ou contextualização e seleção de conteúdos, o acesso a um grande número de informações, seja via internet ou documentos salvos em pastas organizadas no gerenciador do sistema operacional, auxilia o aluno selecionar informação pertinente e organizá-la de modo que consiga recuperá-la facilmente para ser utilizada no texto que será produzido. Vale salientar que esse processo não é o resultado de "copiar e colar", mas sim de contar com um instrumento que permite a pesquisa de informação para alimentação temática, a leitura de outros textos do gênero para ampliação de repertório linguístico e o armazenamento do conteúdo pesquisado, bem como a elaboração de esquemas para a adequada planificação do texto que será redigido, inclusive inserindo formas e figuras que podem colaborar na sua visualização final.

Já na operação de linearização, a vantagem do computador consiste em possibilitar inúmeras edições sem prejudicar o suporte.

No acto de redigir, de dar forma às letras, às palavras e ao texto, a vantagem do computador consiste em possibilitar emendas sem deixar marcas das alterações. A maior parte das pessoas que tem de recorrer à escrita na sua vida profissional passou a escrever directamente ao computador e tira partido desta vantagem. (TAVARES; BARBEIRO, 2011, p. 60).

Por fim, as operações relacionadas à revisão, releitura e reescrita com vistas à versão final do texto exigem, ainda, outros saberes, que deverão vir à tona em decorrência de serem incrementados pelo uso do computador. Uma das principais vantagens incide especialmente na qualidade da legibilidade do texto armazenado. Ao retornar à sua própria produção, o 
escrevente encontrará um material claro para proceder à releitura e nela realizar os ajustes conforme sua intenção de escrita inicial, adaptando-o aos propósitos comunicativos inicialmente estabelecidos. Além disso, contará com recursos do editor de textos, que podem promover uma interessante reflexão sobre questões ortográficas. Conforme assinala Coscarelli:

Ao invés de defender que a tecla F7 (revisor ortográfico) é um recurso que vicia o usuário, que aliena, que torna os escritores descuidados e negligentes, classificando o computador como vilão da vez, devemos ponderar as vantagens de se usar o corretor ortográfico. Esse é um dispositivo que pode ajudar os alunos a criar o hábito de, na dúvida, consultar a grafia correta das palavras num dicionário, seja ele eletrônico ou não, aprendendo com ele sobre ortografia padrão. (COSCARELLI, 2011, p. 35-36).

O uso do computador pode sofisticar a edição de trechos e a revisão lexical - além de disponibilizar ferramentas de revisão ortográfica e sintática -, proporcionar um trabalho mais acurado pelo professor e/ou por outro aluno permitindo que o leitor-revisor insira comentários acerca do produto escrito, salve essas alterações/interações e submeta-as novamente à apreciação do autor, e, ainda, possibilitar a utilização de cores diversas, que podem corresponder a focos de atenção, assim como o uso de grifos e negritos.

A reescrita do produto textual, culminando na versão final do texto, também é facilitada pelo uso do processador, sendo possível salvar suas diferentes versões, auxiliando, inclusive, o acompanhamento do professor na produção dos alunos. Vale salientar que o uso do editor de textos pode incrementar todo o processo de diagramação de textos, que conta com fontes gráficas e recursos gráfico-estilísticos diversos, além da construção de textos envolvendo outras linguagens, como fotos ou desenhos que integram à produção escrita mais qualidade, permitindo a circulação de um texto mais interessante, tanto no meio digital quanto físico, podendo ser impresso e exposto em locais públicos (por exemplo, cartazes), bem como distribuído aos leitores (como panfletos e jornais escolares).

Tavares e Barbeiro (2011) salientam que o mero uso do editor de textos digital ou de outros recursos do computador não garante a formação de bons escritores. O sucesso ou insucesso dependerá muito mais da clareza do professor em direcionar as diferentes etapas do ensino da produção escrita do que da ferramenta de escrita em si. No entanto, ao combinar esse recurso tecnológico ao ensino da produção de textos, possibilita-se de maneira mais 
integrada ao aluno: i) descobrir características dos textos escritos e sua utilização na sociedade; ii) realizar reflexões no interior do processo de escrita; iii) melhores condições de interagir e colaborar em processos de escrita de textos; e iv) atribuir funções aos textos produzidos, tornando a produção de textos mais significativa para ele. Nas palavras dos autores, "o computador surge como um recurso colocado ao serviço de estratégias concebidas para proporcionar o desenvolvimento da relação dos alunos com a escrita" (TAVARES; BARBEIRO, 2011, p. 61).

Assim, os pontos supracitados elencam algumas possibilidades decorrentes da utilização do computador como instrumento de escrita no desenvolvimento do processo e, consequentemente, no produto escrito pelos alunos-autores. Associado ao produto final, o processador de textos digital coloca à disposição dos alunos-autores uma variedade de possibilidades gráficas, como tipos de letras, tamanhos, formatos, diagramação, inserção de figuras, desenhos escaneados, fotos e imagens diversas. A combinação do computador e o processador de textos com outros dispositivos, como a impressora e o escâner, permite que o aluno tenha uma relação diferenciada com o texto de sua autoria, tendo este a possibilidade de ganhar feições muito mais aproximadas aos textos profissionais que circulam socialmente.

As possibilidades trazidas pelo computador em relação à forma constituem um incentivo à criação de um produto, feito à semelhança dos produtos escritos profissionais. Se isso acontece em relação à forma, o mesmo se passa em relação à realização de funções por parte do produto escrito, por meio da sua divulgação. (TAVARES; BARBEIRO, 2011, p. 67).

Além da roupagem mais profissional que o uso do editor de textos associado à impressora garante aos textos que irão circular em papel, há a possibilidade de os textos produzidos circularem em formato digital, ampliando as chances de utilização de elementos multissemióticos. Dessa forma, o computador assume sua função também como instrumento de comunicação, propicia a circulação dos textos produzidos por meio de blogues, redes sociais, e-books, entre outros formatos digitais. 


\subsection{Os estudos desenvolvidos no Brasil}

Realizando uma retomada acerca da relação entre a escola e as tecnologias digitais na distribuição de produtos culturais e seu ensino na sala de aula, Ribeiro (2016a) marca que podemos contar mais de 20 anos de popularização do uso do computador no Brasil. ${ }^{71}$ Esse período representa uma fase produtiva na pesquisa acadêmica sobre o uso das novas tecnologias na sociedade e suas repercussões na escola.

No que tange especificamente aos estudos sobre a influência das novas tecnologias no ensino da leitura e na produção de texto, destacam-se os estudos pioneiros de Luiz Antônio Marcuschi $(1999,2001)$, promovendo a reflexão sobre os processos de linearização, a coerência e o hipertexto, integrando as tecnologias digitais nos estudos da linguística textual. A partir dos anos 2000, ampliaram-se os estudos na área da Linguística Aplicada, que se debruçaram nos usos da tecnologia em aulas de língua, sobretudo de língua materna e Língua Inglesa, conforme caracteriza Ribeiro:

Dos temas escolhidos para a pesquisa que relaciona educação, escola e linguagem, o início tímido, na virada dos anos 2000, apontava trabalhos e pesquisas ligados ao ensino de línguas via softwares ou plataformas digitais, ainda sem muita credibilidade institucional. Ou mesmo trabalhos que buscavam comparar leitura e/ou escrita no papel e na tela, se não sob um viés evolucionista, por um outro mais conciliador, como foi o caso de Coscarelli (1999; 2001) ou Ribeiro (2003; 2008). (RIBEIRO, 2016a, p. 94).

Os trabalhos desenvolvidos por Coscarelli $(2006,2011)$ apresentam boas reflexões sobre as novas questões implicadas nos processos de leitura e produção de texto e suas repercussões nas práticas de ensino e aprendizagem. Ribeiro (2016b) explora de maneira bastante interessante as práticas de ensino da leitura e da produção de textos envolvendo a multissemiose.

Revisando teses e dissertações em Linguística Aplicada e Didática do Ensino de Línguas em geral, observamos, especialmente a partir dos anos 2000, uma quantidade relevante de

\footnotetext{
${ }^{71}$ A autora utiliza o ano de 1995 como "um ano marcante" no processo de popularização dos dispositivos conectados à internet no Brasil (RIBEIRO, 2006, p. 94).
} 
estudos abordando o ensino da leitura e da escrita presencial $^{72}$ ou em modelos de ensino híbrido $^{73}$ com a mediação do computador, no entanto, a maior parte deles está voltada para alunos já alfabetizados, geralmente no período final da escolarização, nos anos finais do Ensino Fundamental II e no Ensino Médio ${ }^{74}$.

Selecionamos três trabalhos que se ocuparam da análise dos processos de leitura e escrita de alunos em período de alfabetização mediados por computador e iremos apresentálos com o intuito de situarmos nossa pesquisa no atual cenário de pesquisas brasileiro. Os trabalhos elencados são aqueles desenvolvidos por Luize (2007), Araújo (2007) e Glória (2011).

Tendo como foco de atenção a produção escrita de alunos em processo de alfabetização com diferentes suportes e riscadores, o trabalho de Luize (2007) apresenta importantes contribuições. O corpus analisado consiste nas produções textuais de crianças da pré-escola organizadas em duplas e variando o suporte e o gênero textual: ora realizaram a produção do texto em papel, ora utilizaram o computador, o editor de texto. De acordo com a autora, o foco da análise está em identificar tendências similares nos processos vivenciados pelas duplas de crianças na elaboração de quatro textos propostos, atentando para o tipo de interferência de um na tarefa do outro (já que as crianças atuaram em tarefas fixas de ditante ou escriba), as discussões sobre a organização do texto, seu conteúdo e a grafia das palavras, entre outros aspectos. Na análise da interação das duplas frente às propostas de produção de texto, a autora considera as discussões que se instauram e o tipo de questão que dá origem a elas (aspectos referentes ao conteúdo, à grafia das palavras e à estrutura dos textos).

Partindo do pressuposto de que as crianças são capazes de produzir textos mesmo antes de dominarem o sistema alfabético de escrita, a autora ressalta que os novos escritores, na faixa etária entre 5 e 6 anos de idade, desvelaram interessantes estratégias quando precisaram conhecer e colocar em prática ações que favorecessem a comunicação que pretendiam estabelecer, entre as quais planejar o que ou como desejavam escrever. Na análise, contrastando as performances de escrita a partir do suporte utilizado, a autora observa que o

\footnotetext{
${ }^{72}$ Para este estudo não consultamos os trabalhos que envolvem programas de ensino à distância, conhecidos como EAD. $O$ estudo de retomada bibliográfica focou apenas nos trabalhos que se desenvolveram presencialmente, em sala de aula regular, em Laboratório de Informática Educativa ou em telecentros.

${ }^{73}$ Cf. PINHEIRO, 2011.

${ }^{74}$ Cf. CAMPOS, 2018; DIAS, 2013.
} 
uso do computador trouxe novos desafios: ao produzirem uma lista no papel, por exemplo, mudar de linha não significou um problema para a dupla, já frente ao editor de textos, as crianças não sabiam como realizar o procedimento (LUIZE, 2007, p. 102).

No entanto, o uso do computador mostrou-se especialmente interessante para a realização da escrita em duplas, favorecendo o acompanhamento do texto por parte de ambas as crianças, pois tanto a criança encarregada da grafia (escriba) quanto a criança encarregada de ditar as letras (ditante) veem de maneira nítida o texto sendo elaborado à sua frente, ao contrário do que ocorre quando se escreve no papel, quando apenas o escriba pode acompanhar de perto cada passo de sua produção (LUIZE, 2007, p. 104-105). De acordo com a autora, essa característica do suporte favoreceu também a operação de revisão de textos, tanto pela visualização das duas crianças quanto pela legibilidade, o que não ocorreu quando a escrita se deu no papel.

\begin{abstract}
Cabe salientar, por fim, que as tentativas de retomada do texto foram mais constantes na produção da lista no computador, assim como foi maior a participação dos ditantes na realização dessa tarefa. O computador traz algumas vantagens quando do acompanhamento da composição do texto pelos autores (ditante e escriba), pois conforme já foi dito, a presença do monitor à frente de ambos permite igual visualização. Além disso, no computador, o texto não está comprometido pelo traçado visual das letras que, nesse caso, são facilmente reconhecidas tanto por quem digita quanto por quem dita. (LUIZE, 2007, p. 106-107).
\end{abstract}

Levando em conta as tendências mais recorrentes, Luize observou questões relacionadas às duas operações envolvidas na produção: as de aspectos notacionais e as de aspectos discursivos. Partindo dessa divisão, a autora aponta que as decisões relacionadas aos aspectos discursivos dos jovens escreventes não apresentaram variações significativas em decorrência do tipo de suporte utilizado. Já as decisões envolvendo aspectos notacionais,

Nas tarefas em que o computador era o recurso de produção, evidenciou-se sistematicamente uma participação mais ampla do ditante a respeito das decisões sobre os aspectos notacionais. Da mesma forma, observaram-se mais tentativas de revisão nas grafias realizadas durante a produção da palavra. (LUIZE, 2007, p. 147).

A produção de textos com o uso de recursos diferentes, o papel e o lápis e o computador, mostrou-se bastante favorável para que problemas de naturezas diversas fossem vivenciados e resolvidos pelas crianças observadas. Além de possibilitar maior interação entre 
os sujeitos-autores, o computador imprime, de fato, uma grande legibilidade ao texto e, ao mesmo tempo, o distancia de seu escritor, permitindo revisões mais apuradas e durante a produção.

A escrita no papel e a escrita no computador trazem, como se pôde verificar na análise feita, desafios e informações diferentes para as crianças. Não se trata de eleger o que é melhor - escrever no papel ou no teclado de um computador -, mas de possibilitar situações em que esses recursos se coloquem como diferenciais tanto nas relações estabelecidas pelas crianças entre si, quanto com a própria língua escrita. A ideia, presente nesta investigação, de alterar a circunstância de produção e analisar cada qual à luz das interações estabelecidas estava associada não apenas ao tipo de texto, mas também ao oferecimento de diferentes recursos materiais tomados como favorecedores para a produção escrita no processo de aprendizagem inicial. (LUIZE, 2007, p. 184).

Em suma, a autora aponta que o computador não é um facilitador, no entanto, é necessário utilizá-lo pelas condições materiais da escrita na atualidade. Ele impõe às crianças novos desafios, bem como estimula determinados comportamentos, como a revisão. Desse modo, o uso do computador não resolveu os impasses das duplas de escreventes; pelo contrário, ao utilizá-lo, as crianças discutiram mais sobre suas produções, e a autora observou muito mais reflexão quando comparadas com as produções manuscritas. Esse movimento de reflexão sobre a própria produção escrita é muito importante, pois assinala que ao longo de toda a vida como escreventes, as pessoas se deparam com problemas a serem solucionados, sejam de ordem notacional ou discursiva, independentemente do material de escrita. Sendo assim, é necessário promover atividades nas quais os alunos possam dialogar e encontrar soluções, para que consigam produzir seus textos da maneira mais interessante ao seu propósito comunicativo.

Data também de 2007 outro interessante estudo sobre práticas de leitura e escrita por alunos de séries iniciais e o uso do computador. Araújo aborda o tema apresentando dados de uma pesquisa-ação em uma escola da rede privada de Fortaleza (PE), na qual crianças de primeira e segunda séries com dificuldades na aprendizagem da escrita e da leitura foram colocadas frente a situações concretas de usos da escrita na internet. Ele se apoia em Soares (1998, p. 47 apud ARAÚJO, 2007, p. 80), que afirma que o ideal "seria alfabetizar letrando, ou seja: ensinar a ler e escrever no contexto das práticas sociais da leitura e da escrita, de modo 
que o indivíduo se tornasse, ao mesmo tempo, alfabetizado e letrado", e, partindo desse pressuposto teórico, problematiza o que é ser um sujeito protagonista no século XXI. Araújo afirma que na atualidade a cidadania dos sujeitos está atrelada não só ao domínio do sistema de escrita alfabético, mas é necessário saber manipular um computador, de preferência conectado à internet, a fim de ocupar um lugar que a sua contemporaneidade lhe impõe. Em outras palavras, os sujeitos precisam ser letrados também digitalmente. Ele apregoa que:

[...] a escola, desde cedo, crie situações didáticas através das quais seja possível trazer para o espaço educativo situações concretas de escrita digital com as quais o educando sinta desejo e necessidade de interagir, pois percebe que são ferramentas sociais portadoras de sentidos, de propósitos comunicativos, e que se traduzem em fontes de informações variadas e de saberes a serem explorados. (ARAÚJO, 2007, p. 80).

Os dados foram gerados a partir da interação dos alunos dos anos iniciais explorando usos básicos dos periféricos (teclado e mouse) para acessar alguns sites infantis, bem como trocar de cartões digitais. Nessa tarefa, as crianças aprendiam também "a noção de link e os recursos que sinalizam esse mecanismo, como a transformação do cursor em uma mãozinha", dando-Ihes a experiência da sensação tátil que os links provocam nos hiperleitores.

Na medida em que avançava a experiência, vários gêneros digitais iam sendo apresentados às crianças para despertar nelas a necessidade da escrita. Assim o e-mail pessoal, o cartão digital, os chats e o endereço eletrônico foram alguns dos gêneros que mais provocaram a percepção nas crianças de que a escrita é uma prática necessária em nossa sociedade letrada. (ARAÚJO, 2007, p. 85).

Uma situação de escrita em contexto de uso concreto relatada pelo autor é a escrita de endereços eletrônicos. Como ela exige plena exatidão dos caracteres - caso contrário, o site desejado não "abre" em tela - ou "compreender a função social da escrita do gênero en dereço eletrônico, que é a de permitir o acesso aos sites" (ARAÚJO, 2007, p. 86), os alunos demonstraram o desenvolvimento do hábito de releitura e reescrita. Relatando sobre a experiência de prática de escrita de um cartão digital, Araújo pontua:

Preparar um cartão digital como o que mostro nessa figura, não é uma tarefa simples para uma criança com o perfil descrito neste artigo, sobretudo pelo fato de todas, na época, estarem ainda em fase de aprendizagem da escrita. Na verdade, era preciso manusear o mouse, o teclado e os muitos formulários eletrônicos que precisavam ser preenchidos à medida que o processo de construção do cartão digital ia acontecendo. 
A essa aprendizagem, chamo de letramento digital, já que durante todo o processo de elaboração a escrita está associada à função social da troca de cartões entre pessoas conhecidas. Ou seja, para além de uma atividade artificialmente criada para o ensino de sílabas, por exemplo, a escrita dos cartões aproximava as crianças de práticas letradas reais vividas por seus pais e familiares. (ARAÚJO, 2007, p. 87).

Outro estudo que teve como foco a escrita utilizando o computador por crianças em processo de alfabetização foi realizada por Glória (2011) em sua tese de doutorado. No referido trabalho, a autora acompanhou crianças de 6 anos ao Laboratório de Informática de escola pública em Belo Horizonte (MG) durante o ano de 2009, em várias atividades de escrita e leitura na tela do computador. A pesquisa usou procedimentos de observação, anotação, filmagem e entrevistas.

Os dados oriundos desse estudo alimentaram os trabalhos desenvolvidos em Glória (2011) e Glória e Frade (2015), que contam com registros de filmagens de propostas de atividades de escrita e leitura na tela do computador com o objetivo de responder à seguinte questão: O que ocorre com as crianças em processo inicial de aquisição da escrita e de alguns de seus gêneros quando utilizam o computador? As autoras consideram o computador mais um instrumento de alfabetização entre tantos outros já utilizados e conhecidos pela escola, colocando em evidência indícios sobre aspectos cognitivos e físicos relacionados ao ato de escrever e ler no novo suporte.

Analisando atividades corriqueiras em turmas de alfabetização, como grafar o alfabeto e realizar cópias, elas a pontam para mudanças qualitativas envolvendo o uso do computador, por exemplo, em atividades de cópia, por estarem "livres" da tarefa de "desenhar" a letra, os alunos se mostraram muito mais atentos a questões relacionadas à segmentação entre palavras, ao uso de letra maiúscula e minúscula e à acentuação.

Os dados põem em evidência o fato de que, mesmo quando não trabalhamos atividades com gêneros textuais virtuais, repetindo práticas escolares semelhantes às que desenvolvemos com a escrita manuscrita, notamos que as ferramentas digitais transformam e dão uma nova roupagem à tarefa, ou melhor, aparecem novos aspectos cognitivos e físicos relacionados ao ato de escrever e ler. Com isso, os alunos, muitas vezes, voltam sua atenção para estruturas da escrita ou para aspectos gráficos não percebidos quando operavam com outro formato e outro suporte de texto. (GLORIA; FRADE, 2015, p. 356). 
Por fim, as pesquisadoras constataram que quando ocorrem situações de escrita autêntica ou de simulação de uso, as crianças apreendem o valor social da escrita, promovendo uma escrita mais fluida e significativa. Desse modo, reforçam que ao introduzirmos novos artefatos da cultura da escrita nas aulas de leitura e produção de textos, os alunos encontram maior sentido na escrita e podem refletir sobre as continuidades e rupturas da cultura escrita, bem como sobre os gestos e comportamentos que a cultura digital propicia.

Os três estudos abordados acima são bons representantes de trabalhos que exploram a inserção dos computadores nas aulas de produção textual. Todos eles partem de uma perspectiva enunciativa buscando promover situações de produção escrita contextualizadas e refletem sobre como o uso do computador pode incrementar essas práticas.

No próximo capítulo, abordando o contexto no qual a pesquisa foi desenvolvida, faremos algumas observações sobre as alterações que a inserção dos dispositivos digitais, em especial os computadores, acarreta na dinâmica interativa dos espaços institucionais de aprendizagem. 


\section{Instrumentos digitais de escrita e interação em sala de aula}

Conforme buscamos explicitar nos capítulos anteriores, os processos de ensino e aprendizagem da língua escrita foram paulatinamente alterados de acordo com as tecnologias desenvolvidas ao longo da história e como elas foram sendo popularizadas e incorporadas pela sociedade e pela instituição escolar. Assim, é válido reforçar, nos apoiando em Kenski (2007, 1998), que o termo "tecnologia" engloba a totalidade de artefatos produzidos pelos humanos a partir da utilização de recursos existentes, com a finalidade de conquistar algum benefício de interesse privado ou para a coletividade.

Diversos autores (COSCARELLI, 2011; KENSKI, 1998; ROJO, 2017) salientam que ao longo da história da humanidade, o desenvolvimento de tecnologias interfere nos modos como os humanos organizam o tempo e o espaço, bem como nos modos de reter e lembrar informações, funções usuais com que os homens armazenam e movimentam suas memórias, alterando profundamente sua relação com o conhecimento (KENSKI, 1998, p. 59). Assim, é fato que já se constatam reconfigurações no tempo e espaço dos alunos da atualidade, usuários contumazes dos celulares multifuncionais em suas rotinas extraescolares, e que suas relações com os saberes (acadêmicos, vivências de mundo) foram extremamente impactadas em decorrência das tecnologias digitais. A escola - e de maneira mais específica, a sala de aula - também vai pouco a pouco incorporando as tecnologias que se popularizam e buscando formas de ajustar seus tempos e espaços a esses novos aparatos.

Neste capítulo, retomando os anos finais da década de 1980, apresentaremos uma breve reconstituição do modo como os computadores estão sendo incorporados ao espaço escolar no contexto brasileiro e, de modo mais específico, da rede municipal de ensino da cidade de São Paulo. 


\title{
3.1. O espaço da sala de aula: mobiliário e materiais de escrita
}

Analisando três fotografias que retratam salas de aulas de escolas públicas paulistas ao longo de cem anos (de 1908 a 2007), Vidal salienta:

\begin{abstract}
Ao observar as fotografias, a primeira coisa que identificamos é a notável permanência dos elementos estruturantes da organização das salas de aula: a distribuição dos alunos em filas e voltados para a mesma direção; a existência de suportes da escrita, como folhas soltas, cadernos e quadros-negros; a utilização de objetos para escrever, como giz, lápis e canetas; a posição corporal dos estudantes, sentados em cadeiras e com os braços apoiados em mesas, e dos professores, em pé. (VIDAL, 2009, p. 28).
\end{abstract}

A citação da autora aponta a permanência de alguns artefatos ao longo de um século, como mesas apoiando cadernos e lápis e suas cadeiras organizados em fileiras, de maneira que toda a atenção esteja voltada ao professor e à lousa. De acordo com Tavares e Barbeiro (2011), a forma escolar centrada na escrita organizava-se primordialmente de modo a privilegiar o espaço individual por meio do uso de carteiras pesadas, que delimitavam uma distância entre os alunos. Na organização mais tradicional da sala de aula, é comum o uso do estrado, uma estrutura plana, em geral de madeira, que se assemelha a um palanque baixo, construída a alguns centímetros acima do nível do chão, para que, ao formar um piso mais elevado, ponha em destaque a pessoa que se encontra nela. A lousa fica alocada no centro do espaço do estrado, na altura dos braços da professora. Esse conjunto, composto por estrado e lousa, configura o que comumente chamamos de "frente da sala de aula", ou seja, o lado para o qual a postura corporal de todos está voltada.

De acordo com Vidal (2009) e Tavares e Barbeiro (2011), com o passar do tempo, as carteiras pesadas foram substituídas por um mobiliário mais leve que, embora fosse composto também por mesas e cadeiras, permitia reconfigurações, como o trabalho em duplas ou grupos. No entanto, reformular o mobiliário implica na alteração da postura dos alunos e, consequentemente, no seu foco de atenção. As novas configurações alteram também a interação entre professor e alunos em sala de aula.

Conforme observamos no capítulo 1, o advento da lousa associada à reunião de um número maior de alunos nos grupos escolares permitiu a organização do ensino simultâneo 
seriado em contraposição ao ensino individual. Observamos também que as escolas que aderiam ao método lancasteriano ou mútuo exigiam mobiliário e materiais didáticos (placas, livros, caixas de areia) muito diferentes daqueles adotados nas escolas de ensino simultâneo, o que atesta que a disposição dos sujeitos e as tecnologias adotadas na composição do espaço de sala de aula estão intimamente relacionadas com a proposta teórico-metodológica adotada pela instituição (CHARTIER, A-M., 2011; TANCK DE ESTRADA, 1990; VIDAL, 2009).

A arquitetura da sala e a disposição dos móveis (mesas, carteiras, cadeiras, armários e lousas) definem o tipo de proposta teórico-metodológica vigente. $O$ espaço destinado a professores e alunos também declara de quem é a primazia da ação. Os espaços físicos concretos de nossas escolas estão comprometidos com um tipo de educação que privilegia a atuação do professor, o seu movimento e a centralização do processo no ato de ensinar, de transmitir, de informar. (KENSKI, 2007, p. 108).

Ao inserirmos computadores de mesa, computadores portáteis, celulares multifuncionais, projetores e outros artefatos no conjunto de materiais disponíveis na sala de aula, temos como resultado um impacto direto nos modos como a interação aí se desenvolve. Desse modo, a escola precisa readequar tempos e espaços às funções pedagógicas das tecnologias e aos equipamentos que for introduzindo (TAVARES; BARBEIRO, 2011). A seguir, vamos conhecer algumas das possibilidades de adequação do espaço escolar ao uso pedagógico ${ }^{75}$ dos computadores.

\subsection{O dispositivo comunicativo em sala de aula}

Desde o advento da grande placa de ardósia coletiva (BARRA, 2013) e do painel pintado com tinta escura (TANCK DE ESTRADA, 1990) - ou como o chamamos, quadro-negro -, o ensino pôde ser simultâneo (em que o professor ensina diversos alunos com níveis de conhecimento semelhantes), em oposição ao ensino individual (em que o professor ensina um aluno de cada

\footnotetext{
${ }^{75}$ A distinção "uso pedagógico" é feita em oposição a "uso burocrático" por Lopes (2010). O uso pedagógico implica o uso dos computadores para o desenvolvimento de atividades que visam os processos de ensino e aprendizagem, inclusive a formulação de atividades pelos docentes. Já o uso burocrático consiste na utilização dos computadores de modo restrito às demandas da secretaria e gestão escolar.
} 
vez, de acordo com suas dificuldades), por contar com um dispositivo comunicativo centralizado, ou seja, todos os participantes, alunos e professor, têm a possibilidade de visualizar a mesma informação ${ }^{76}$. A tecnologia do quadro-negro também permite que os participantes da interação possam, além de visualizar um determinado conteúdo, realizar modificações no que está exposto, tendo a possibilidade de constantemente apagar e reconfigurar o conteúdo que está sendo abordado. Assim, as salas de aula que possuem quadronegro, lousa branca, projetor e/ou lousa digital interativa dispõem do que Tavares e Barbeiro (2011) denominam dispositivo comunicativo centralizado. O uso de dispositivos comunicativos centralizados acaba por justificar a organização da sala nas tradicionais fileiras individuais ou em fileiras de duplas ou, ainda, na configuração de semicírculo, pois permite que a atenção do grupo esteja centralizada em um único dispositivo de comunicação (TAVARES; BARBEIRO, 2011, p. 23).

Com o surgimento e a popularização dos computadores de mesa - e, mais recentemente, dos dispositivos portáteis, como laptops, tablets e celulares multifuncionais -, temos ainda mais possibilidade de desenhos de leiaute da sala de aula, pois eles operam como dispositivos comunicativos descentralizados, ou seja, os alunos têm à frente a possibilidade de manusear diversos conteúdos em seu próprio ritmo, podendo seguir as consignas colocadas pela professora ou trilhar outros caminhos e, desse modo, despender o tempo de maneira mais personalizada, dado que, supostamente, têm maior autonomia na relação com o conteúdo abordado.

Cabe salientar que nas salas em que se pode contar com computadores e dispositivos portáteis, é comum que o computador gerenciado pelo professor esteja conectado a um projetor, justamente para que determinadas informações sejam difundidas de modo centralizado.

A seguir, apresentaremos a proposta de "versões tecnológicas de sala de aula" de Dudeney, Hockly e Pegrum como uma possibilidade para se pensar a gradação dos recursos tecnológicos na sala de aula.

\footnotetext{
${ }^{76}$ Vale lembrar que o agrupamento dos alunos em prédios escolares maiores foi outro fator que permitiu que fossem juntados aqueles com conhecimentos similares em relação à leitura e à escrita e, assim, que se adotasse uma concepção metodológica do ensino simultâneo.
} 


\section{Quadro 3 - Versões da sala de aula}

\begin{tabular}{|c|l|}
\hline $\begin{array}{c}\text { Versão alta } \\
\text { tecnologia }\end{array}$ & $\begin{array}{l}\text { Sala de aula em que o professor dispõe de um computador conectado à internet e } \\
\text { acoplado a um projetor. Os estudantes têm acesso (em número suficiente) a } \\
\text { computadores conectados à internet ou a dispositivos móveis que lhes permitem } \\
\text { trabalhar em pequenos grupos, duplas ou até individualmente. }\end{array}$ \\
\hline $\begin{array}{c}\text { Versão } \\
\text { baixa } \\
\text { tecnologia }\end{array}$ & $\begin{array}{l}\text { Sala de aula em que o professor dispõe de um computador ligado à internet e conectado a } \\
\text { um projetor. Os estudantes não têm acesso a computadores conectados à internet ou a } \\
\text { dispositivos móveis. }\end{array}$ \\
\hline $\begin{array}{c}\text { Versão zero } \\
\text { tecnologia }\end{array}$ & Sala de aula em que não há computador ligado à internet. \\
\hline
\end{tabular}

Fonte: Adaptado de Dudeney, Hockly e Pegrum (2016, p. 69).

É válido observarmos que muitas das salas de aula que, de acordo com a tabela acima, poderiam ser consideradas como versão de alta tecnologia não são salas regulares, mas espaços diferenciados conhecidos como Laboratório de Informática Educativa ou sala de informática.

\subsection{O uso pedagógico dos computadores nas escolas públicas brasileiras}

Abordando de maneira específica o caso do Brasil ao longo dos anos 1990 e 2000, observamos o desenvolvimento de algumas políticas para equipar as escolas públicas com computadores, visando o desenvolvimento de atividades pedagógicas. Carvalho e Monteiro (2012) e Lopes (2010) destacam nesse cenário a relevância do Programa Nacional de Tecnologia Educacional (Prolnfo), criado em 1997 vinculado ao Ministério da Educação (MEC), cujo objetivo era promover o uso pedagógico de Tecnologias de Informação e Comunicações (TICs) na rede pública de Ensino Fundamental e Médio. Tendo sido reformulado em 2007, ganhou o nome de Prolnfo Integrado, ampliando o escopo das ações propostas que, em termos gerais, engloba três grandes eixos: o primeiro refere-se à implementação da infraestrutura da escola com a implantação de laboratórios de informática e dos programas Projetor Prolnfo - que consiste em um projetor acoplado a um computador - e Um Computador por Aluno (UCA); o segundo diz respeito ao Programa de Capacitação de Professores no uso de Tecnologias de Informação e Comunicação na Educação; e o terceiro se relaciona à oferta de conteúdos educacionais e de outras mídias, como no caso do Canal TV Escola e do Portal do Professor e do Aluno. 
Observamos que as três modalidades previstas na vertente da implantação de infraestrutura operam com possibilidades de organização dos recursos digitais tanto centralizados quanto descentralizados. Assim, as diferentes modalidades do Prolnfo possibilitam: i) Laboratório de Informática Educativa (dispositivo comunicativo descentralizado); ii) computador conectado a projetor (dispositivo comunicativo centralizado), mobiliário com carteiras enfileiradas ou semicírculos; e iii) um computador por aluno ou modelo 1-1, em que cada aluno tem seu dispositivo móvel, fazendo uso dele na maioria das aulas (dispositivo comunicativo descentralizado).

Dos três modelos implementados pelo Prolnfo, por meio da análise realizada por Bizeli e Sebastian-Heredero a partir do relatório desenvolvido pela Comissão de Gestão da Internet publicado em 2014, é possível afirmar que o modelo Laboratório de Informática Educativa ainda é o mais comumente encontrado nas escolas brasileiras, dado que:

[...] observa-se que $99 \%$ das escolas públicas localizadas em áreas urbanas do país possuem computador, mas o número médio de computadores nas escolas é de 19,1 enquanto o número médio de alunos por escola é de 653. (BIZELI; SEBASTIANHEREDERO, 2016, p. 60).

A discrepante relação entre número de alunos versus número de computadores aponta para a concentração dos dispositivos em uma única sala, como no modelo Laboratório de Informática Educativa. Em ampla pesquisa em que discute os usos pedagógicos dos computadores em escolas públicas urbanas brasileiras, Lopes aponta como uma das principais conclusões da análise que "o número de professores que usam a tecnologia com seus alunos é ainda pequeno e este uso se dá eminentemente no laboratório de informática" (LOPES et al, 2010, p. 328).

Quais as vantagens e desvantagens do modelo Laboratório de Informática? Ainda na década de 1990, Seabra (1993), apoiado em artigos publicados nos Estados Unidos no início dessa década, defende que a ideia de concentrar todos os computadores em um único ambiente favorece o que ele denomina de ensino da informática, ao invés da inserção da informática no ensino. Esse modelo, nomeado na pesquisa internacional como computer labcentric e implantado em sistemas educacionais americanos e em outros países industrializados 
na década de 1980, foi amplamente criticado por pesquisadores da área da Tecnologia da Educação, no entanto, a despeito das considerações acadêmicas realizadas, o modelo foi largamente difundido em países em desenvolvimento, como no Brasil. As pesquisas desenvolvidas por Trucano (2005) confirmam que esse modelo ainda é predominante em países em desenvolvimento e observam que esses ambientes seguem alguns padrões típicos de organização das antigas aulas de datilografia, sendo muitas vezes justificado por conta de questões relacionadas à segurança dos equipamentos, à climatização do ambiente e às necessidades elétricas especiais, como número e disposição de tomadas.

Em virtude da predominância do modelo Laboratório de Informática Educativa, geramos os dados de pesquisa nesse ambiente, espaço tecnologicamente equipado mais comum nas escolas públicas paulistanas. A seguir, esmiuçaremos os modos como frequentemente se dá a organização do espaço e do tempo nesse local. ${ }^{77}$

\subsubsection{A interação nos Laboratórios de Informática Educativa: o espaço e o tempo}

Em relação ao modo como se deu a implementação dos computadores nas escolas públicas brasileiras, Carvalho e Monteiro (2012) assinalam a existência de duas cartilhas elaboradas pelo MEC no âmbito do programa Prolnfo, uma destinada às escolas urbanas e outra destinada às escolas rurais, nas quais constam instruções gerais e específicas a serem seguidas para montar a estrutura dos laboratórios de informática. Apresentando uma série de especificações técnicas, como as dimensões dos ambientes e as instalações elétricas, as cartilhas sugerem um leiaute padrão: os laboratórios das escolas urbanas devem ser estruturalmente organizados em formato de $U$, enquanto nas escolas rurais essa estrutura consiste na organização de alguns poucos computadores na sala de aula regular. Assim, a orientação do leiaute é mais justificada por questões técnicas (como alimentação da energia) do que por orientação pedagógica, visando a melhor organização interacional para os processos de aprendizagem.

\footnotetext{
${ }^{77}$ Os detalhes do contexto no qual foram gerados os dados estão explicitados no capítulo 4.
} 
Nesse sentido, as cartilhas não têm uma preocupação pedagógica, por exemplo, em problematizar o layout dos laboratórios de acordo com pesquisas que apontam a importância da disposição física das máquinas para favorecer as interações e os processos de ensino e de aprendizagem. (CARVALHO; MONTEIRO, 2012, p. 349).

Na figura abaixo, observamos a orientação de leiaute apresentada na cartilha destinada às escolas urbanas:

Figura 2 - Leiaute padrão dos laboratórios de informática educativa

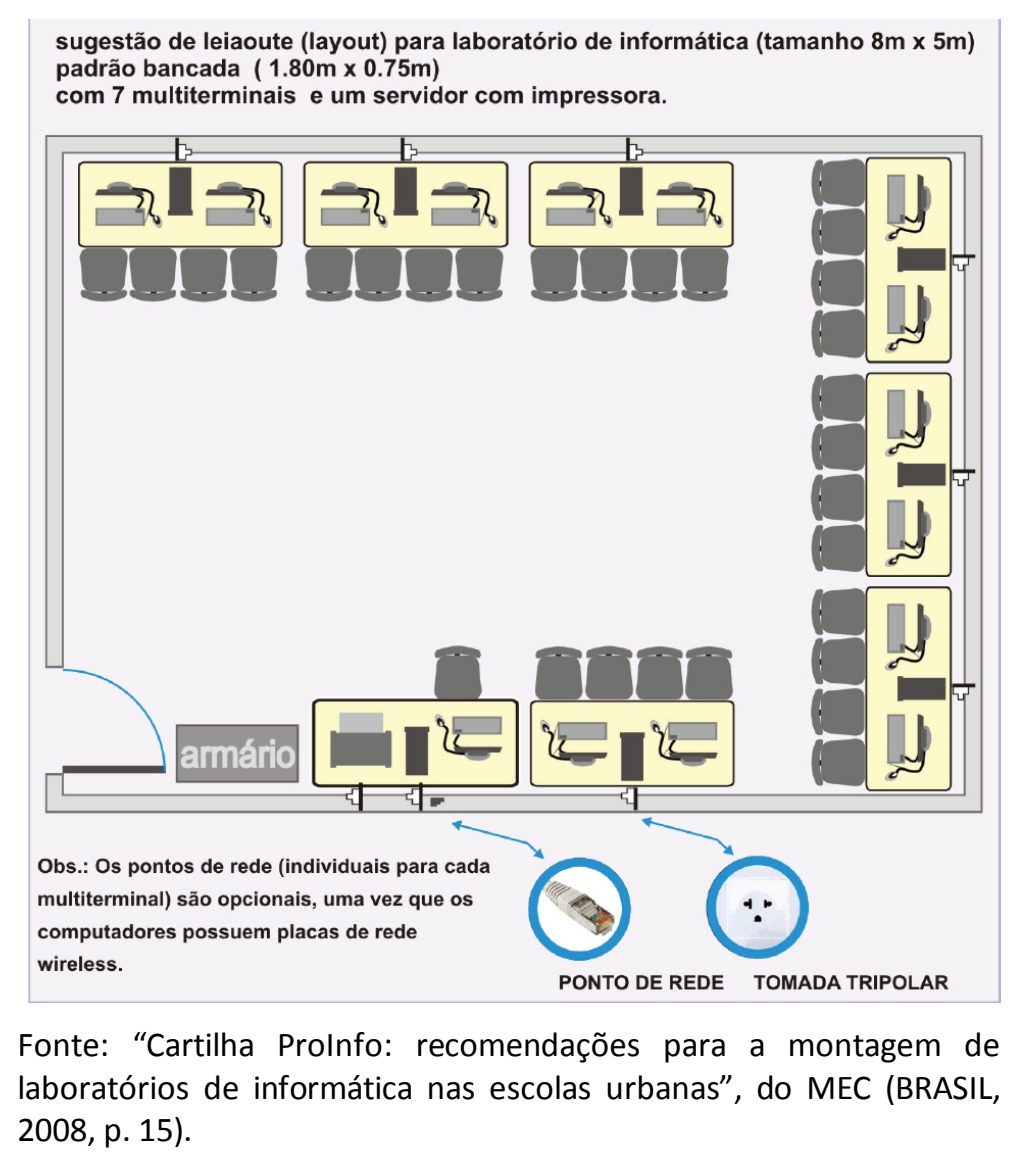

Na cartilha destinada às escolas urbanas, não há orientações a respeito da instalação de projetores conectados a um dos computadores, o que configuraria a presença de um dispositivo centralizado no interior da lógica do Laboratório de Informática. A única sugestão de dispositivo comunicativo centralizado consta no item "Recomendações Opcionais", a qual descreve as proporções de quadro branco, caso se opte por sua inserção no espaço. 
Quadro de laminado melanínico branco ("quadro branco"), com dimensões mínimas de $1,5 \mathrm{~m} \times 1,25 \mathrm{~m}$, para ser fixado à parede com calha-suporte para marcadores. A utilização de quadro com giz é inadequada no ambiente com microcomputadores, pois o acúmulo de pó nestes equipamentos poderá prejudicar o seu funcionamento ou reduzir a vida útil destes. (BRASIL, 2008, p. 11).

Restringindo nosso olhar para a rede municipal de São Paulo, da qual é integrante a escola na qual os dados foram gerados, Dutra (2010) aponta que as primeiras investidas em prol da inserção de computadores nas escolas datam da década de 1980, em projetos esparsos e com viés profissionalizante. No início da década de 1990, época em que Paulo Freire era secretário da rede municipal de educação, houve um importante redimensionamento dos projetos envolvendo informática educativa, visando o uso de computadores no interior de projetos interdisciplinares. Apesar do caráter inovador conferido pela gestão Freire/Erundina, 0 modelo Laboratório de Informática Educativa foi adotado pela política pública implantada.

No que tange ao leiaute do Laboratório de Informática Educativa da rede municipal de São Paulo, observamos que desde os anos 1990 há um formato predominante: os computadores são organizados em formato de $U$, e o professor pode circular livremente pelo centro da sala. Tal configuração é marcada pelo fato dos alunos ficarem de costas para o professor, no entanto, é curioso observar que, apesar de o professor perder o contato visual com o aluno, como seria esperado em uma sala com dispositivo centralizado, a organização em U permite que ele observe livremente a tela do aluno, até mesmo sem que este saiba que seu trabalho está sendo monitorado.

Analisando como a introdução dos dispositivos digitais redimensiona o espaço da sala de aula, Kenski (1998) aponta modificações em ao menos dois aspectos. O primeiro deles é relacionado ao espaço físico: dispondo dos dispositivos digitais, novos deslocamentos são necessários, os alunos encontram-se ora em frente ao computador, ora em grupo para discutir os resultados de sua produção ou pesquisa no ambiente tecnológico; não há mais a distribuição de folhas ou livros, as tarefas podem ser projetadas ou acessadas via plataformas ou em documentos compartilhados em espaços virtuais. O segundo ponto diz respeito aos procedimentos de acesso ao saber, pois contar com dispositivos conectados à rede mundial permite 
[...] o acesso a outros locais de aprendizagem - bibliotecas, museus, centros de pesquisas, outras escolas etc... com os quais alunos e professores podem interagir e aprender - modifica toda a dinâmica das relações de ensino-aprendizagem. (KENSKI, 1998, p. 70).

Apesar das mudanças apontadas, o estudo desenvolvido por Dutra sobre o uso das tecnologias nas escolas mostra como se desvelam os elementos de transição da sociedade disciplinar para uma sociedade de controle fundados no interior da teoria de modernidade sólida para a modernidade líquida ${ }^{78}$. O autor assinala que apesar da reformulação espacial dos laboratórios de informática, esse novo espaço não rompe com a lógica escolar.

Pelo menos até o momento, a entrada do computador na escola não demitiu certos atributos associados a uma escola disciplinar, panóptica, ligada a muitos dos pressupostos da modernidade sólida. Nesse sentido, Veiga-Neto (2000, p. 106) lembra que a perspectiva de "criar/moldar o sujeito cliente" não significa, necessariamente, na "demissão daquele grande objetivo que norteou a escolarização na Modernidade". Para Veiga-Neto, a escola foi pensada e continua funcionando como uma "imensa maquinaria de confinamento disciplinar". (VEIGA-NETO apud DUTRA, 2010, p. 106).

Já no que tange à organização do tempo e analisando o tempo de utilização dos computadores por professores e alunos de escolas públicas brasileiras, Lopes aponta que

[...] professores usam 3,2 vezes na semana sozinhos e 2,6 vezes por semana com seus alunos. Neste último caso, a frequência de uso é menor por terem que rodiziar o único espaço da escola com máquinas suficientes para a classe: o laboratório de informática. Talvez a frequência de uso aumente caso haja outros espaços em que a tecnologia esteja disponível ou caso haja laptops em número suficiente. (LOPES et al., 2010, p. 310).

Assim, a partir dos dados apresentados, é possível observarmos que o uso da tecnologia é bastante restrito à lógica de funcionamento da grade disciplinar, atuando, de fato, como mais uma disciplina que integra o currículo escolar. De maneira semelhante, na rede municipal de educação de São Paulo, as turmas frequentam o Laboratório de Informática Educativa conforme estabelecido na grade horária, uma vez por semana, podendo ampliar esse uso caso algum projeto especial esteja sendo desenvolvido. Essa aula semanal é regida por uma professora específica, denominada Professora Orientadora de Informática Educativa (Poie), que representa uma função especializada na escola, deixando de lecionar a disciplina para a qual foi formada e

\footnotetext{
${ }^{78}$ Cf. BAUMAN, 2001 apud DUTRA, 2010.
} 
admitida em concurso público e passando a assumir uma nova função considerada como atividade docente, no entanto, arca com novas atribuições.

[...] seu papel vai além daquele exercido pelos professores das disciplinas tradicionais, ao incorporar funções como a da própria organização do espaço do laboratório de informática, pois cabe a ele, inclusive, mapear os computadores que porventura não estiverem funcionando e entrar com o serviço de manutenção. Mas, também, tem a função de formar outros professores e difundir o uso de tecnologia entre os membros do corpo docente. (DUTRA, 2010, p. 108).

Ainda de acordo com Dutra, a Poie geralmente ministra aulas sem o acompanhamento de outros professores, apesar das atividades deverem estar integradas com aquelas desenvolvidas em sala de aula regular. A partir do ano de 2014 , com a reorganização dos ciclos na rede municipal paulistana, alguns anos passaram a contar com mais de uma aula na semana e com a presença da professora da turma/disciplina específica atuando ao lado da Poie. ${ }^{79}$ Essa especificidade da função de Poie pressupõe que esse profissional tenha uma atuação mais ampla no contexto escolar, tendo contato com todo o corpo docente e participando do desenvolvimento dos planejamentos e da execução dos projetos, especialmente dos interdisciplinares.

\subsubsection{As tarefas desenvolvidas em Laboratório de Informática Educativa}

Retomando o amplo estudo quantitativo desenvolvido por Lopes et al (2010) envolvendo escolas públicas de áreas urbanas de capitais das cinco regiões brasileiras, observamos que naquelas em que o computador é utilizado para fins pedagógicos, os programas de computador mais utilizados pelos professores - tanto sozinhos quanto com seus alunos - são os menos complexos, como, por exemplo, os editores de textos e editores de apresentação. Conforme podemos conferir no gráfico abaixo, o editor de textos figura como o programa mais utilizado com alunos:

\footnotetext{
${ }^{79}$ Traremos mais detalhes sobre a organização do trabalho no capítulo 4.
} 


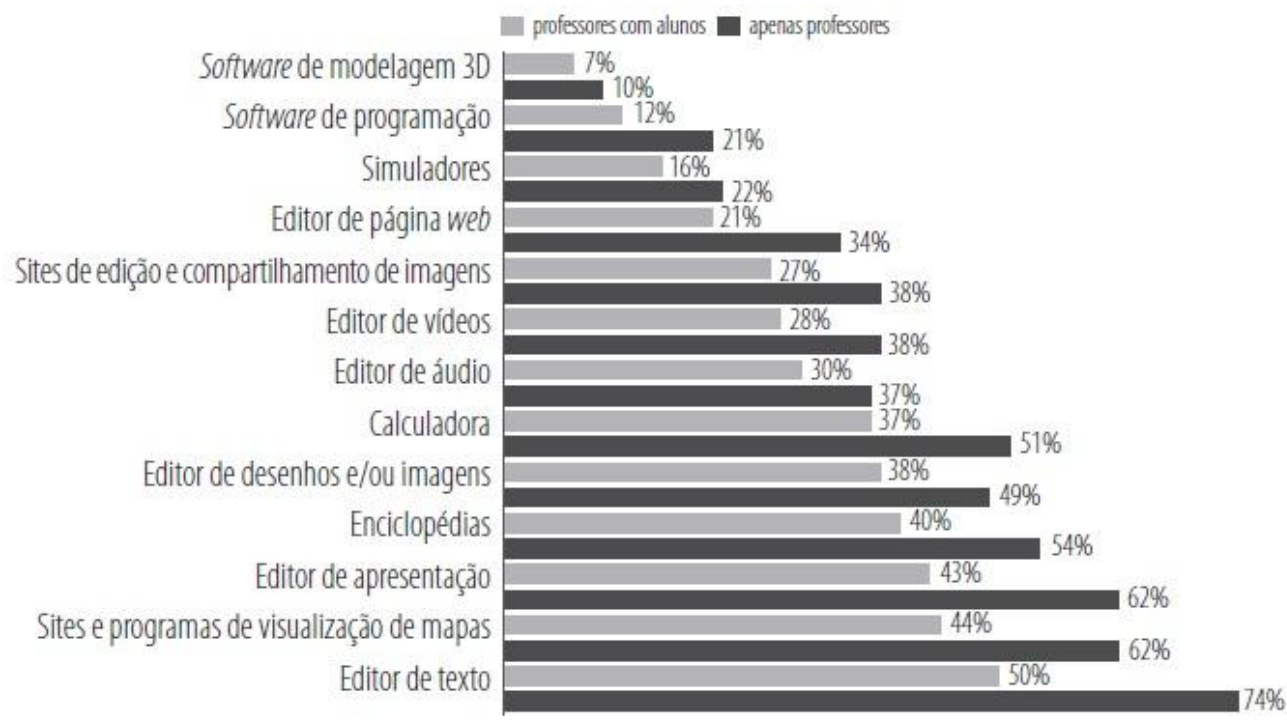

Fonte: LOPES et al (2010, p. 313).

Avaliando as tarefas escolares envolvendo o uso de tecnologias nas aulas de língua materna, Dudeney, Hockly e Pegrum (2016) assinalam que devem ser consideradas tanto a competência linguística quanto a competência tecnológica dos estudantes. Dentre o conjunto de atividades envolvendo o uso de tecnologias para o letramento digital, os autores assumem que a maior parte é destinada a alunos dos anos finais do Ensino Fundamental e apontam que "o maior desafio está mais em usar atividades nos níveis iniciais do que nos níveis finais da educação básica" (DUDENEY; HOCKLY; PEGRUM, 2016, p. 302). Apesar da ressalva, eles afirmam que é possível adequar as atividades para qualquer nível de escolarização, tendo em vista que o uso da tecnologia é sempre focado em atividades que culminarão em produções dos alunos. Salientando a competência linguística dos estudantes, destacam:

[...] os estudantes criarão produtos digitais que refitam a linguagem das quais sejam capazes. Um estudante do final do ensino fundamental I produzirá um texto simples, que pode necessitar de acompanhamento e apoio da professora no estágio da criação. O texto dele também pode carecer passar por várias reescritas antes de estar apresentável. Um estudante do ensino médio produzirá um texto digital com estruturas linguísticas muito mais complexas e vocabulário mais amplo e pode não necessitar de muita reescrita, embora algumas reescritas ainda possam ser valiosas. (DUDENEY; HOCKLY; PEGRUM, 2016, p. 302). 
Em respeito à competência tecnológica, os autores assinalam que há geralmente uma grande heterogeneidade nas turmas. Eles listam três fatores que geram grandes diferenças nas competências tecnológicas já adquiridas pelos estudantes: o primeiro incide em questões como posição socioeconômica, nível educacional, localização geográfica, gênero, etnia e língua, com grande impacto tanto no acesso quanto nas habilidades digitais, criando uma crescente muralha digital $^{80}$; o segundo refere-se à variação do interesse de crianças e jovens estarem on-line, assim, as competências construídas são muito distintas; o terceiro é que mesmo os alunos que se mostram experientes no manejo digital, o fazem para seu entretenimento e com propósito de interação social. Sendo assim, é necessário que os alunos sejam convidados a realizar tarefas com foco no desenvolvimento de ferramentas voltadas a objetivos educacionais e profissionais, bem como para desenvolverem uma compreensão crítica das ferramentas tecnológicas disponíveis.

A seguir, explicitaremos as especificidades do ambiente escolar e da população de alunos acompanhados na geração de dados desta pesquisa.

${ }^{80}$ O termo "muralha digital”, ou "divisão digital”, refere-se à lacuna entre as pessoas habilitadas a fazer uso efetivo das tecnologias digitais e aquelas que carecem de tais habilidades (DUDENEY; HOCKLY; PEGRUM, 2016, p. 32). 


\section{O contexto de pesquisa: escola e organização do sistema municipal de ensino}

A geração de dados ocorreu ao longo do 2 o semestre letivo do ano de 2016. A escola locus da investigação é uma escola pública municipal que atende alunos da educação básica - os nove anos do Ensino Fundamental -, concebendo a idade ideal de ingresso os 6 anos e tendo a idade ideal de conclusão os 14 anos de idade. ${ }^{81}$

Essa rede adotou desde o ano de 2014 o Programa Mais Educação São Paulo, que envolve a organização do ensino básico em três ciclos: Ciclo de Alfabetização (1으, 2o e 3o anos),

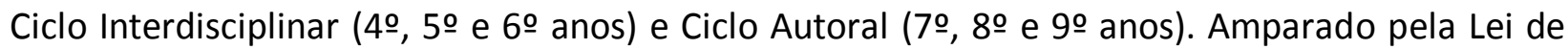
Diretrizes e Bases da Educação nacional no 9394/96, que faculta aos sistemas de ensino desdobrar o Ensino Fundamental em ciclos, o documento que institui as diretrizes de implantação do Programa Mais Educação São Paulo, da Secretaria da Educação, justifica:

[...] a organização em ciclos de aprendizagem permite a construção/apropriação do conhecimento em períodos em que a singularidade dos estudantes seja respeitada em seus ritmos e considere sua condição social, cognitiva e afetiva. Também fortalece concepções de educação no que tange à garantia dos direitos e objetivos de aprendizagem de maneira a assegurar a formação básica comum e o respeito ao desenvolvimento de valores culturais, étnicos, artísticos, nacionais e regionais. (SÃO PAULO, 2014, p. 74).

No que toca ao uso de tecnologias digitais, assim como as demais escolas da rede municipal, a escola contava com um Laboratório de Informática Educativa e a atuação da Poie, modelo que já se mostra consolidado na rede há quase 30 anos, conforme explicitamos anteriormente ${ }^{82}$.

\footnotetext{
${ }^{81}$ A escola foi criada em 1957, recebendo o nome de Escolas Agrupadas de Vila Sônia e funcionando em um pequeno prédio com três salas. Em 1969, já no prédio atual, passou a ser denominada Emef Desembargador Theodomiro Dias.

${ }^{82}$ Maiores detalhes sobre a criação e organização dos Laboratórios de Informática Educativa estão disponíveis neste trabalho, capítulo 3.
} 


\section{1. $\quad 0$ ciclo de alfabetização: espaços e materiais de escrita}

As turmas acompanhadas do 3 o ano do Ciclo de Alfabetização contavam com, aproximadamente, 30 alunos matriculados. 0 espaço no qual se desenvolviam as atividades de ensino e aprendizagem eram, na maior parte do tempo, as respectivas salas de aula, tendo na figura da professora polivalente a principal referência dos alunos dentro da instituição escolar, porém outros profissionais compunham a carga horária do Ciclo de Alfabetização. As salas de aula eram equipadas com quadros-negros e carteiras. Os materiais que circulavam nas atividades de leitura e escrita eram cadernos, lápis, borrachas, canetas e os livros, tanto os fornecidos pelo Programa Nacional do Livro Didático (PNLD) quanto o material desenvolvido pela própria Secretaria da Educação, os "Cadernos de Apoio e Aprendizagem", que consistem em três volumes de livros consumíveis: Língua Portuguesa, Matemática e Ciências. Além dos livros, as professoras quase sempre utilizavam folhas fotocopiadas, com tarefas que, após serem realizadas, deveriam ser coladas no caderno da respectiva disciplina. As fotocópias também eram corriqueiras na realização das avaliações bimestrais. Nas duas salas acompanhadas, as professoras faziam uso frequente dos livros, embora não realizassem todas as tarefas previstas, pois costumavam alternar o uso de um ou outro material, a depender do conteúdo em foco e das respostas do grupo de alunos.

A grade curricular dos 3 anos era composta pelo total de 30 aulas semanais, sendo 25 aulas ministradas pela professora regente polivalente e cinco aulas distribuídas entre: duas aulas de Educação Física, uma aula de Artes, uma aula no ambiente Sala de Leitura e uma aula no ambiente Laboratório de Informática Educativa. As cinco aulas ministradas sem a presença da professora regente eram conduzidas por professores especialistas em Educação Física ou Artes e por professores de formação diversa, assumindo os espaços Sala de Leitura e Laboratório de Informática Educativa.

Além dessas cinco aulas, estão previstas em portaria específica o exercício da Docência Compartilhada (doravante DC), definida como a copresença de dois professores em sala - as duas aulas de Língua Estrangeira ocorriam nesse modelo. A grade curricular pode ser 
incrementada ainda, a depender da organização da unidade, com mais duas aulas em regime de DC nos ambientes Sala de Leitura e Laboratório de Informática Educativa.

O princípio da docência compartilhada pressupõe o planejamento conjunto dos professores especialistas/professores do Ensino Fundamental II e do professor polivalente/professor de Educação Infantil - Ensino Fundamental I, de acordo com o Projeto Político-Pedagógico (PPP) de cada unidade educacional, articulados pelo Coordenador Pedagógico, de forma que o trabalho de um não se sobreponha ao do outro - eles se complementam. (SÃO PAULO, 2014, p. 110).

No contexto desta pesquisa, os $3^{\text {os }}$ anos desfrutaram de duas aulas em regime DC no ambiente Laboratório de Informática. Para o desenvolvimento dessas aulas, propusemos a organização de sequências didáticas envolvendo uma situação comunicativa que previa a produção de uma regra do jogo bastante popular entre os alunos e que precisaria ser redigida, impressa e compartilhada por todos eles, de modo a realizarem um campeonato. Dessa feita, para que pudessem circular em outros espaços, previu-se o uso de tecnologias digitais como ferramentas necessárias para a produção, edição, diagramação e formatação de textos, por isso a maior parte da sequência didática foi desenvolvida em Laboratório de Informática Educativa.

É importante ressaltar que elegemos as turmas do 30 ano especificamente por estarem em uma posição limítrofe na organização do sistema de ensino: é um momento peculiar para a análise da aprendizagem da produção textual. O documento que institui as diretrizes do Ciclo de Alfabetização salienta que "ao longo dos três anos, devem ser respeitados os diferentes modos de aprender e seus diversos ritmos como processos intersubjetivos sócio-históricos e culturais" e deve ser garantido "ao final do Ciclo, a alfabetização, de forma que sejam capazes de ler e produzir textos de diferentes gêneros com autonomia" (SÃO PAULO, 2014, p. 75, grifos nossos). Assim, de acordo com o documento, encerrando o primeiro ciclo previsto na organização do sistema de ensino municipal, o 3ำ ano representa a etapa em que os alunos deveriam apresentar produções textuais dominando o sistema de escrita alfabética e manejando com proficiência razoável os diversos gêneros textuais. No entanto, conforme observaremos na análise dos dados, o sistema de escrita alfabético ainda é um desafio para boa parte dos alunos acompanhados. 
A aquisição incipiente da língua escrita somada a novas demandas curriculares representava um desafio à atuação docente, pois o planejamento das tarefas de leitura e produção escrita precisam considerar os diferentes níveis de aprendizagem dos alunos, acarretando questões que envolvem o tempo e os modos como a interação em sala de aula é organizada, como, por exemplo, os agrupamentos produtivos e o planejamento de atividades diferenciadas, de maneira que cada aluno possa trabalhar com uma tarefa possível para seu nível de desenvolvimento e que, ao mesmo tempo, represente um desafio. Assim, o planejamento precisa ser maleável, de modo a representar boas situações de aprendizagem para todos os alunos apesar da heterogeneidade em relação à aprendizagem do sistema de escrita alfabética.

No que tange aos saberes envolvendo as tecnologias digitais, os alunos frequentavam as aulas de Informática Educativa desde o 10 ano. Assim, já apresentavam razoável familiaridade com o uso do mouse e do teclado, bem como com a dinâmica de interação da sala.

\subsection{O Laboratório de Informática Educativa da unidade escolar}

O ambiente Laboratório de Informática Educativa compreendia uma sala no andar térreo da escola, onde também ficavam o pátio, o refeitório, a sala dos professores, a brinquedoteca e a sala de vídeo. As demais salas de aula encontravam-se no andar imediatamente superior. A infraestrutura física do ambiente era bastante diferente da sala de aula convencional. A principal diferença incidia na presença de 19 computadores; 15 deles ficavam em um balcão ao longo das quatro paredes da sala (Figura 3). Esses eram os computadores ocupados pelos alunos, sendo cada um deles manejado por uma dupla de alunos previamente selecionada de acordo com o desenvolvimento da aprendizagem, especialmente no que tange à aprendizagem do sistema de escrita alfabética. 
Figura 3 - Vista ampla do ambiente Laboratório de Informática Educativa

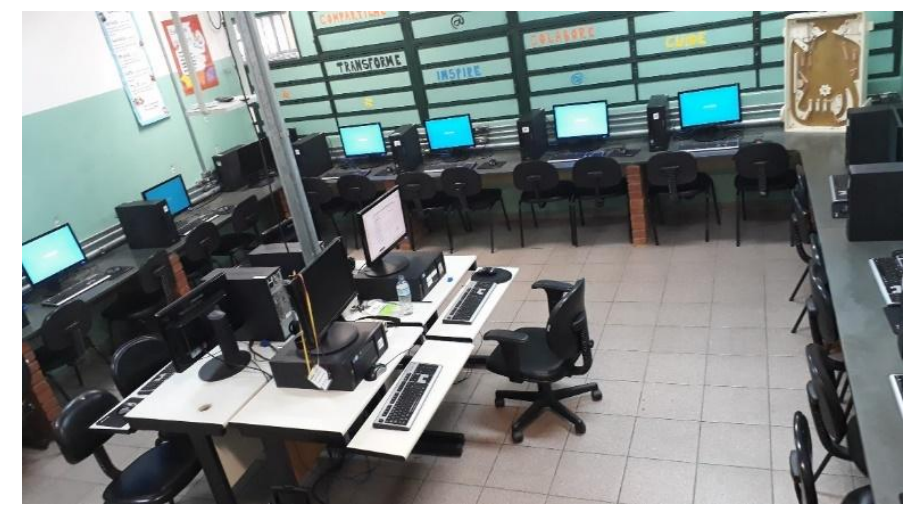

No centro da sala, havia uma ilha composta por quatro mesas com quatro computadores. Dois desses computadores cumpriam funções idênticas aos outros 15 que acabamos de descrever; os outros serviam para o gerenciamento da sala, sendo um deles o servidor - desktop que controla os demais computadores da sala operado pela professora - e o outro, ao lado do desktop, conectado por um cabo HDMI a um aparelho de televisão e a uma caixa de som (Figura 3).

A interação no ambiente Laboratório de Informática Educativa apresenta especificidades ao comparada à interação em sala convencional. De modo geral, como é possível confirmar por meio da observação das Figuras 3 e 4, a atenção dos alunos é, por uma questão ergonômica, voltada para a tela do computador, ou seja, as cadeiras estão voltadas para os computadores, logo, os alunos ficam de costas para o professor, leiaute padrão desses ambientes, conforme descrevemos no capítulo anterior.

Assim, retomando as possibilidades de dispositivos de comunicação abordadas, observamos que esse ambiente permite tanto o uso de dispositivo comunicativo centralizado quanto o uso de dispositivo comunicativo descentralizado. Essas duas opções presentes no ambiente dão uma gama maior de possibilidades interativas. Quando as atividades eram previstas para serem desenvolvidas em duplas, os textos eram projetados na tela dos desktops dos alunos. Já quando o coletivo de alunos deveria trabalhar de maneira mais ajustada aos passos previstos pela professora, os conteúdos eram projetados na televisão disponível no 
ambiente. O funcionamento em rede também permitia que a professora fizesse a moderação por meio do uso dos gerenciadores de rede.

Figura 4 - Uso da televisão no ambiente Laboratório de Informática Educativa

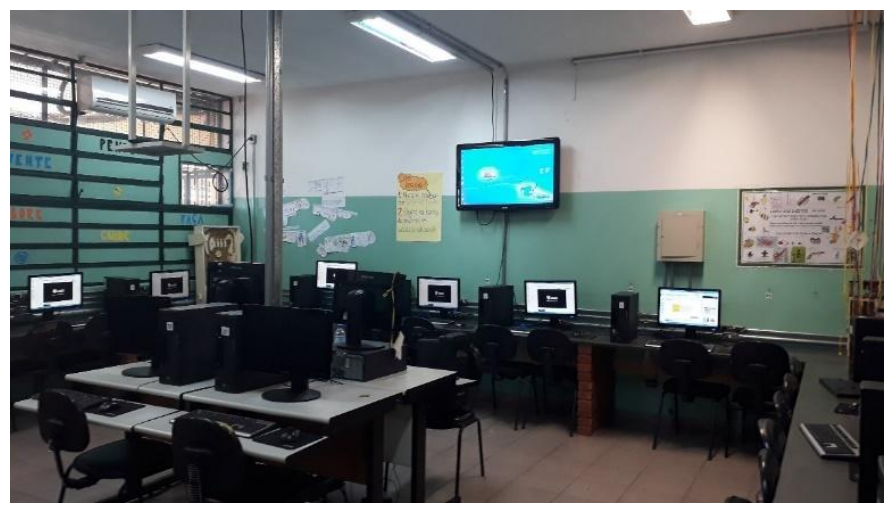

Esse recurso incrementa as possibilidades audiovisuais da sala e se configura em uma opção instrumental para o professor. Nas paredes, observamos ganchos com fones de ouvido, cartazes com lembretes e divulgação de projetos em andamento e/ou já desenvolvidos. Não havia lousa convencional.

\subsection{A organização em rede}

Os computadores do ambiente estavam conectados à internet e intraconectados localmente por meio de um switch ${ }^{83}$. Essa conexão local era feita por meio de softwares ${ }^{84}$ de gerenciamento de rede.

Os gerenciadores permitiam o total controle das ações dos alunos a partir do servidor. Assim, ao início da aula, por exemplo, os alunos encontravam os computadores bloqueados, com uma mensagem de boas-vindas. Esse recurso impedia que eles iniciassem o manejo do computador antes de ouvirem o comando das professoras.

\footnotetext{
${ }^{83}$ Aparelho eletrônico que conecta todos os computadores em rede. Sua função é concentrar e distribuir as requisições feitas pela rede.

${ }^{84}$ Os softwares utilizados no contexto pesquisado são o Blue Control e o Blue Lab.
} 
Figura 5 - Bloqueio dos computadores dos alunos por meio do software de gestão da rede

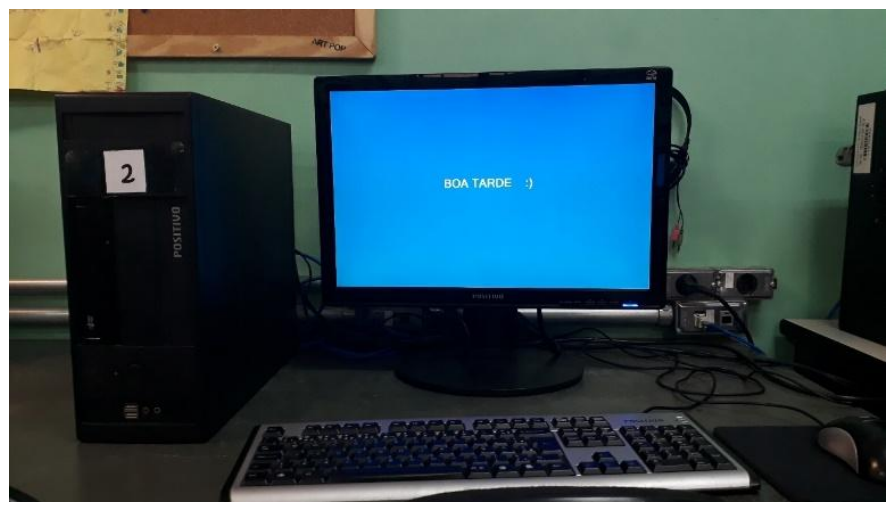

Como a professora podia bloquear o acesso ao computador, ela enviava por meio do servidor qual seria a atividade do dia. Se a organização didática da aula previsse, por exemplo, a leitura de um texto postado em um blogue, a professora enviava o link para os alunos, e assim todos tinham à frente, ao mesmo tempo, o material disponibilizado, podendo "rolar" a página conforme seu ritmo de leitura. Se a aula previsse a apreciação de um vídeo, as telas permaneciam bloqueadas e o vídeo era enviado apenas para o computador conectado à televisão. Nesse caso, todos precisavam direcionar a atenção para um único suporte material. 


\section{A produção de texto nos documentos que orientam o ensino no 3ำ ano}

Para caracterizar os modos como o ensino da produção de textos é orientado por meio dos documentos oficiais, apresentaremos os dois mais utilizados pela equipe escolar. O primeiro é o material publicado pela Secretaria Municipal de Educação da cidade de São Paulo (SME), que atuou como principal norteador da gestão do quadriênio de 2013 a 2016 e instituiu o Programa Mais Educação São Paulo (SÃO PAULO, 2014). O segundo documento, "Currículo Escolar", desenvolvido pelas docentes da unidade escolar locus da investigação, nasceu de uma articulação entre o que está previsto no Programa Mais Educação e as características da comunidade escolar, com o objetivo de atuar como um facilitador no momento do planejamento das aulas.

Em relação ao documento emitido pela SME, o ciclo de alfabetização é caracterizado da seguinte forma:

O Ciclo de Alfabetização (1으, 2o e 3o anos), consubstancia-se na aprendizagem das crianças de 6 a 8 anos. A meta é alfabetizá-las considerando suas potencialidades, seus diferentes modos de aprender e seus diversos ritmos como processos intersubjetivos sócio-históricos e culturais. (SÃO PAULO, 2014, p. 75, grifos nossos).

No que tange ao ensino da leitura e da escrita, o documento assume uma "concepção de alfabetização considerada na perspectiva do letramento" (SÃO PAULO, 2014, p. 76) e traduz esse direcionamento teórico da seguinte forma:

Que o estudante avance rumo a alfabetização não somente na aprendizagem do sistema de escrita, mas também nos conhecimentos sobre as práticas, usos e funções da leitura e da escrita, o que implica o trabalho com todos os componentes curriculares e em todo o processo do Ciclo de Alfabetização. (SÃO PAULO, 2014, p. 76).

As habilidades relacionadas à leitura e escrita são especificadas neste documento como pontos que devem representar conquistas reveladas ao final de cada um dos anos que compõem o ciclo, conforme a divisão:

Vale observar que, para o final do 10 ano do Ciclo de Alfabetização, as crianças devem ter se apropriado do sistema de escrita alfabética e conseguir ler e escrever palavras, frases e textos, mesmo que com dificuldade. No 20 ano, deve ser garantido o progresso 
dos conteúdos e das aprendizagens e, ao final do Ciclo, a alfabetização, de forma que sejam capazes de ler e produzir textos de diferentes gêneros com autonomia. (SÃO PAULO, 2014, p. 76).

Assim, observamos que recai sobre o 3 o ano o prazo para que os conhecimentos relacionados ao sistema de escrita alfabética, incluindo os conhecimentos acerca de suas práticas e funções sociais, estejam efetivamente consolidados. De acordo com o documento, essas expectativas estão alinhadas com o Pacto Nacional pela Alfabetização na Idade Certa (PNAIC) ${ }^{85}$. Dentre as diretrizes do pacto, a capacidade de leitura e produção de textos ao longo de toda a escolarização é o elemento central. Por conta disso, a normativa já aponta a produção de textos escritos desde o 10 ano do Ensino Fundamental.

O segundo documento, elaborado pelo próprio corpo docente da escola sob a orientação da coordenadora pedagógica, o "Currículo Escolar" ${ }^{86}$, tem como objetivo delimitar os objetos de ensino a serem desenvolvidos ano a ano, de modo a garantir a sistematização e a programação dos conteúdos, numa tentativa de articular o que está prescrito nos documentos governamentais com o Projeto Político Pedagógico da unidade escolar. No que diz respeito a seu conteúdo, o documento é iniciado com a descrição dos direitos de aprendizagem em Língua Portuguesa. No 3ㅇan ano, elenca:

Compreender e produzir textos orais de diferentes gêneros. Produzir textos escritos de gêneros específicos. Trabalho com outros gêneros envolvendo algumas personagens já conhecidas pelas crianças (múltiplos sentidos do leitor). Compreender alguns textos do cotidiano escolar. Participar de situações de escuta e produção oral e de pequenos textos escritos envolvendo temas sociais relevantes/preconceito racial, de gênero e linguístico. (cf. ANEXO A).

Na sequência, o documento delimita alguns procedimentos de uma rotina semanal de leitura, salientando a importância em se garantir momentos em que haja "leituras contextualizadas em voz alta". Por fim, apresenta um quadro apontando cinco diferentes gêneros que devem ser trabalhados e abordados nas práticas de leitura, análise linguística e

\footnotetext{
${ }^{85}$ À época da geração dos dados, o documento que norteava a delimitação das expectativas de aprendizagem era o "Elementos Conceituais e Metodológicos para a Definição dos Direitos de Aprendizagem e Desenvolvimento do Ciclo de Alfabetização", formulado pelo MEC em 2012.

${ }^{86}$ ANEXO A.
} 
produção de texto ao longo do 3ㅇano: bilhete, receita, regra do jogo, verbete de dicionário e notícia.

\subsection{O gênero regra do jogo}

A concepção de sujeito que perpassa a normativa da SME para o Ciclo de Alfabetização pontua dois elementos que conformam o trabalho com o gênero regra do jogo no Ciclo de Alfabetização. O primeiro é conceber a criança como produtora de cultura (SÃO PAULO, 2014, p. 76), assim, o trabalho envolvendo leitura e escrita a partir de suas vivências com jogos e brincadeiras do cotidiano a coloca no lugar de produtora de textos, muitas vezes ensinando regras e outras particularidades de um evento que lhe é comum, tanto em sua comunidade quanto em momentos de recreação na escola. Ao trazer um repertório próprio, a sensação de assimetria típica da sala de aula tende a esmaecer, e o aluno constrói uma relação mais horizontal com o conhecimento: ao mesmo tempo em que conhece a regra, a executa e a reproduz oralmente, o professor pode auxiliá-lo na organização de um campeonato, na definição de uma regra escrita única, na reflexão sobre o vocabulário próprio do jogo, na popularização e no reconhecimento entre os outros sujeitos da escola, entre outras habilidades.

O segundo ponto do documento é a premissa de que se contemplem atividades lúdicas, como o brincar, o ouvir, o contar e ler histórias com ou para as crianças, de modo que "a cognição e a ludicidade caminhem juntas e integradas para garantir os espaços de apropriação do conhecimento" (SÃO PAULO, 2014, p. 76). Dessa maneira, ao incluir o gênero regra do jogo no currículo escolar, é propiciado um espaço tanto para a reflexão acerca do sistema de escrita quanto a inserção de práticas culturais próprias da infância.

Com o intuito de situar o gênero, recorreremos à delimitação feita por Dolz e Schneuwly (2004), que listam cinco aspectos tipológicos a partir dos quais os textos podem ser classificados: narrar, relatar, argumentar, expor e descrever ações. Textos de instruções e prescrições se enquadram na última tipologia, descrever ações, por haver uma espécie de regulação mútua de comportamentos. De acordo com Kaufman (1995), os textos instrucionais 
são aqueles cuja função é regular ou indicar formas de agir, que descrevem etapas que devem ser seguidas para que se consiga fazer algo, como preparar uma torta, instalar um eletrodoméstico ou realizar a manutenção de um automóvel. Como os demais gêneros textuais, apresentam tema, modo composicional e estilo específicos: numerais que indicam quantidade ou ordenação de ações, abreviaturas, verbos no infinitivo ou imperativo, ilustrações, entre outras características.

Caracterizando textos injuntivos, Travaglia (1991) propõe uma superestrutura apresentando três categorias esquemáticas:

i) O elenco ou descrição em que se apresentam os elementos a serem manipulados na ação a ser realizada. Seriam, no caso das receitas, a lista de ingredientes. Já nos manuais, os itens frequentemente são substituídos por fotos ou desenhos, com indicação dos nomes e funções.

ii) A determinação ou incitação em que se apresentam as situações a serem realizadas.

iii) A justificativa, a explicação ou o incentivo em que se dá razões para a realização das ações previstas na determinação.

A superestrutura proposta pelo autor não é fixa, e as partes podem se intercalar. Dentre os diversos textos injuntivos, há aqueles que Travaglia (1991, p. 181) chama de "planos", como receitas, manuais de montagem e regras do jogo. São textos que ordenam ações de forma prática, sendo apresentadas na melhor sequência de execução das situações para atingir o fim pretendido. Assim, nesses textos, o modo como se apresentam as ações representa um elemento central, pois qualquer inversão causa um problema ao leitor.

Val e Barros definem como injuntivo "àquele tipo de texto que se caracteriza por organizar informações e instruções ou ordens com a finalidade de orientar determinado comportamento do interlocutor" (2008, p. 135). Elas apresentam um estudo com dados gerados com crianças de 7 anos de idade, em sua maioria não alfabetizadas e oriundas de classes sociais em que os adultos são pouco escolarizados. A análise das autoras afirma que as crianças detinham conhecimento sobre os textos de tipo injuntivo, tanto ao produzirem oralmente o gênero receita quanto ao produzirem oralmente instruções da regra do jogo. 
A análise dos dados autoriza a afirmação geral de que as crianças entrevistadas tinham conhecimento do tipo injuntivo e revelaram esse conhecimento quando produziram textos tanto do gênero receita quanto do gênero regras de jogo. Esse tipo de texto está presente no cotidiano das crianças, em receitas caseiras de alimentos e remédios e nas instruções partilhadas de jogos e brincadeiras, enquanto "gêneros primários" (cf. BAKHTIN, 1979/1992), em sua modalidade falada. (VAL; BARROS, 2008, p. 143).

Desse modo, em função das práticas sociais das quais as crianças participavam produzindo oralmente textos injuntivos, elas se mostraram, em geral, capazes de produzir textos orais cujas informações estavam ordenadas de acordo com o processo que descreviam ou sobre o qual teciam instruções. De acordo com as autoras, os problemas começavam quando as crianças são convidadas a redigir as receitas e instruções que sabem reproduzir oralmente. Nas produções escritas, observaram com frequência casos de incompletude e implicitação na interlocução face a face e o emprego de recursos linguísticos pertinentes à modalidade oral.

As autoras concluem que as crianças trabalhavam de maneira satisfatória com a unidade textual, dominando as características principais do gênero, no entanto, precisavam trabalhar com linguísticas próprias do texto escrito, especialmente por preverem um interlocutor modelo que já deteria um bom conhecimento contextual, pois, ao longo da construção do texto, pressupunham uma grande capacidade de inferência por parte do interlocutor.

Não vislumbrando um leitor distanciado, vale-se, na composição, de recurso usualmente mais produtivo na língua falada que na escrita: os dêiticos (vai partindo assim; pula um assim; vira assim). Seu interlocutor modelo deve ser alguém que partilha conhecimentos e práticas culturais, posto que algumas informações fundamentais - e por isso mesmo, óbvias - não são explicitadas no texto. (VAL; BARROS, 2008, p. 161).

O apagamento de informações consideradas sabidas é frequente até mesmo na produção de adultos proficientes e é explicada pela natureza interativa da escrita, em que o produtor de texto "se orienta pela imagem mental que faz dos conhecimentos do seu interlocutor e, buscando informatividade, deixa de explicar aquilo que the parece já sabido ou facilmente inferível" (VAL; BARROS, 2008, p. 146). Neste estudo, que focou o processo de produção oral e leitura de textos injuntivos, as autoras concluem que esse tipo de texto, por sua possibilidade de construção icônica, correspondendo à percepção do processo real que quer representar, mostra-se como composição potencialmente fácil para a criança, mesmo que ela ainda não domine os processos de controle e gestão desencadeados pela aprendizagem da 
escrita para a elaboração de seu pensamento. Por outro lado, quando solicitadas a lidar com a produção de textos na modalidade escrita, representando de modo lexicalizado e sintaticizado procedimentos e imagens que se traduziriam mais facilmente por gestos e movimentos, apresentam grandes dificuldades. 


\section{O processo de geração dos dados}

A proposta de analisar o processo de produção de textos com o uso de computadores por alunos recém-alfabetizados partiu da atuação da pesquisadora como professora de Informática Educativa e de suas pesquisas sobre interação em sala de aula e ensino de língua materna (GOMES-SANTOS; JORDÃO, 2014; JORDÃO, 2011, 2017; JORDÃO; NONATO, 2018). Integrando a prática como professora de Língua Portuguesa e de tecnologias aplicadas à Educação com a experiência acadêmica, propomos uma pesquisa-ação, com o intuito de aprimorar a prática pela oscilação sistemática entre agir na prática e investigar a respeito dela (TRIPP, 2005). Desse modo, a intenção foi investigar situações reais de ensino propondo um novo processo, exequível no interior da lógica de funcionamento da escola pública, conforme os pressupostos da pesquisa-ação:

[...] consiste em uma alternativa de pesquisa que coloca a ciência a serviço da emancipação social, trazendo duplo desafio: o de pesquisar e o de participar, o de investigar e educar, realizando a articulação entre teoria e prática no processo educativo. (TOZONI-REIS, 2009, p. 31).

A pesquisa foi situada em uma perspectiva da realidade social tomada como uma totalidade em sua estrutura e em sua dinâmica, partindo da realidade concreta da vida cotidiana dos próprios participantes em suas dimensões e interações. De acordo com Brandão e Borges (2007), esse tipo de pesquisa exige uma mirada especial na dimensão histórica do objeto de estudo abordado, pois constitui-se como elemento importante na reconstrução do passado próximo ou, mais ainda, no olhar entre o presente e o futuro. Em virtude de retomarmos essa perspectiva histórica, nos capítulos anteriores delineamos os modos como o ensino da produção escrita na escola elementar ocorreu, desde a conformação da forma escolar moderna até os dias atuais, nos quais estamos vivenciando a introdução das tecnologias digitais nas aulas de ensino de língua materna.

Desse modo, inseridos no contexto escolar, propusemos o desenvolvimento das sequências didáticas em torno do gênero regra do jogo nas aulas regidas em docência compartilha em laboratório de informática educativa, com o uso do editor de texto Word. 
Foram utilizadas três câmeras modelo câmera de mã $0^{87}$. A primeira, alocada nas mesas centrais, capturava a interação geral da sala. As outras duas foram alocadas no balcão, com o auxílio de um tripé, ao lado de duas duplas de trabalho escolhidas de acordo com o nível de desenvolvimento do sistema de escrita alfabético. Como não dispúnhamos de microfones de lapela, a câmera foi colocada na altura do rosto dos alunos, voltada para a tela do computador no qual estavam trabalhando, de modo que fosse possível capturar a interação verbal dos alunos e a produção escrita desenvolvida. Acreditamos que, mesmo dispondo de poucos recursos, o modo como as câmeras foram utilizadas permitiu que capturássemos a interação entre a dupla de alunos e a produção em sincronia, possibilitando recuperar exatamente o que os alunos conversaram sobre cada aspecto da produção escrita.

\subsection{As sequências didáticas acompanhadas}

Conforme descrevemos acima, elencamos o gênero regra do jogo como objeto de ensino. Essa escolha deveu-se tanto à sua prescrição nos documentos que orientam o ensino do 3ㅇano quanto às características dos alunos com os quais trabalhamos.

Dentre os jogos comuns à faixa etária, elegemos o "Jogo dos Cards" para ser objeto de produção. Extremamente popular entre os alunos à época da geração dos dados, ele se desenvolve da seguinte maneira: os alunos reúnem diversas figurinhas compradas em bancas de jornal, estampadas com imagens diversas - jogadores de futebol, personagens de desenhos animados, personagens de telenovelas, entre outros -; eles geralmente se reúnem sentados no chão e juntam em uma pilha as figurinhas cards que cada participante possui; assim que determinam quem iniciará a jogada, por meio do Jo-Ken-Po - jogo que se assemelha ao par ou ímpar -, começam a bater a palma das mãos nas figurinhas com o intuito de virá-las; quem vira mais figurinhas é o vencedor. Essa atividade causava transtornos no cotidiano escolar, pois além dos alunos executarem o jogo em praticamente todos os momentos livres que tinham dentro da escola, muitas vezes jogavam no meio das aulas regulares.

\footnotetext{
87 As câmeras utilizadas eram do modelo Sony HDR-CX405 Full HD Zoom e foram gentilmente cedidas pelo Professor Doutor Sandoval Nonato, orientador desta pesquisa.
} 
A ocorrência do jogo durante as aulas era considerada um problema para o andamento das aulas, por isso era comum que as figurinhas cards fossem retiradas dos alunos pelo professor regente ou até mesmo pelo diretor ou coordenador da escola. Outro problema eram as brigas ocasionadas pela perda das figurinhas cards por algum dos participantes. Diversos casos de agressões físicas e verbais eram relatados após os alunos discutirem em torno das regras divergentes, que consideravam ser a mais justa ou a mais correta. Dessa forma, a eleição de um único jogo, comum a maioria dos alunos, prendeu a atenção dos grupos, os motivou à escrita e criou uma situação de escrita real: era necessário pensar coletivamente uma regra única para que pudessem executar um Campeonato de Cards ao final do ano letivo.

Outro ponto que chamava muito a atenção da equipe docente era o vocabulário que o jogo envolvia. Era comum as professoras relatarem que não compreendiam o que os alunos falavam ao executar as jogadas. Muitas vezes, para mediar conflitos, os alunos utilizam expressões completamente incompreensíveis aos docentes, coordenadores e agentes escolares, o que dificultava a resolução dos problemas interpessoais. Logo, no planejamento envolvendo a regra do tal jogo, pensou-se que seria interessante dar espaço aos alunos para que refletissem acerca dessa atividade e para que o jogo pudesse ser melhor compreendido pela equipe de educadores.

Assim, a proposta de produção inicial apresentou uma situação comunicativa, solicitando que os alunos escrevessem as regras de modo que as professoras pudessem entender o jogo tão estimado por eles. A partir da escrita inicial, realizamos diversos módulos que trabalhavam as diferentes características linguísticas desse gênero textual e, ao final, a escrita coletiva da regra do jogo. Foram dez atividades desenvolvidas no total: oito realizadas em Laboratório de Informática Educativa, uma em sala de aula regular e, por fim, o evento - o Campeonato de Cards na mostra cultural da escola, com a participação de alunos diversos, incluindo seus familiares.

Abaixo, um quadro resumo das atividades desenvolvidas: 
Quadro 4-Resumo das atividades planejadas na sequência de ensino

\begin{tabular}{|c|c|}
\hline ATIVIDADE & DESCRIÇÃO/OBJETIVOS \\
\hline 1. Produção inicial & $\begin{array}{l}\text { As professoras solicitam que duplas de alunos } \\
\text { escrevam as regras do jogo, de modo que uma } \\
\text { pessoa possa compreendê-lo e executá-lo. O } \\
\text { objetivo é verificar o que os alunos conhecem } \\
\text { acerca do gênero - regulação interna. }\end{array}$ \\
\hline $\begin{array}{l}\text { 2. Análise coletiva de texto seguida por revisão do } \\
\text { próprio texto }\end{array}$ & $\begin{array}{l}\text { Problematizar pontos do texto ligados à } \\
\text { composição e estrutura a partir de texto } \\
\text { produzido por uma dupla de alunos. }\end{array}$ \\
\hline 3. Leitura aplicada Jo-Ken-Po & $\begin{array}{l}\text { A partir da leitura de uma regra retirada de um } \\
\text { site especializado em jogos, observar elementos } \\
\text { típicos do texto. Nessa atividade, o texto era } \\
\text { modificado pelas professoras, aglutinando alguns } \\
\text { vocábulos com o objetivo de trabalhar a } \\
\text { segmentação de palavras. }\end{array}$ \\
\hline $\begin{array}{l}\text { 4. Revisão com uso de dicionário (texto regra do Jo- } \\
\text { Ken-Po) }\end{array}$ & $\begin{array}{l}\text { Utilizando a regra do Jo-Ken-Po, selecionam-se } \\
\text { vocábulos pouco comuns e apresentam o } \\
\text { dicionário on-line. }\end{array}$ \\
\hline $\begin{array}{l}\text { 5. Construção de quadro com elementos gerais do } \\
\text { gênero regra do jogo }\end{array}$ & $\begin{array}{l}\text { Análise do texto Jo-Ken-Po focando sua estrutura } \\
\text { textual. }\end{array}$ \\
\hline 6. Revisão coletiva & $\begin{array}{l}\text { A partir do quadro síntese de elementos do } \\
\text { gênero construído na última aula, os alunos } \\
\text { revisam a própria produção textual. }\end{array}$ \\
\hline 7. Revisão: do coletivo para o individual & $\begin{array}{l}\text { Assemelha-se à atividade 2: problematizar } \\
\text { pontos do texto ligados à composição e estrutura } \\
\text { a partir de texto produzido por uma dupla de } \\
\text { alunos. Mas nessa ocasião, a revisão conjuga } \\
\text { elementos mais sofisticados. }\end{array}$ \\
\hline 8. Inserindo figuras & $\begin{array}{l}\text { Trabalhar como o uso de figuras, desenhos ou } \\
\text { esquemas pode incrementar a produção textual } \\
\text { do gênero. }\end{array}$ \\
\hline 9. Leitura aplicada dos cards & $\begin{array}{l}\text { Em grupos, na sala de aula regular, os alunos } \\
\text { executam as regras escritas até o momento e } \\
\text { realizam os ajustes necessários a partir de } \\
\text { problemas enfrentados na execução do jogo. }\end{array}$ \\
\hline 10. Construindo vocabulário & $\begin{array}{l}\text { Definição dos termos utilizados em jogo que não } \\
\text { constam no dicionário e/ou que têm uma } \\
\text { significação distinta no contexto do jogo. }\end{array}$ \\
\hline 11. Campeonato de Cards & $\begin{array}{l}\text { Fechamento da sequência: tornar público o } \\
\text { trabalho desenvolvido para toda a comunidade } \\
\text { escolar. }\end{array}$ \\
\hline
\end{tabular}


No que tange ao ensino da produção, nos inspiramos na organização da sequência didática de Dolz, Noverraz e Schneuwly (2004), que apresenta uma proposta enunciativa do ensino da produção escrita partindo da exposição da situação comunicativa e produção inicial, e a partir dos resultados obtidos, desenvolvemos os módulos envolvendo as atividades necessárias para o incremento da produção final, conforme modelo abaixo:

Figura 6 - Estrutura base de uma sequência didática

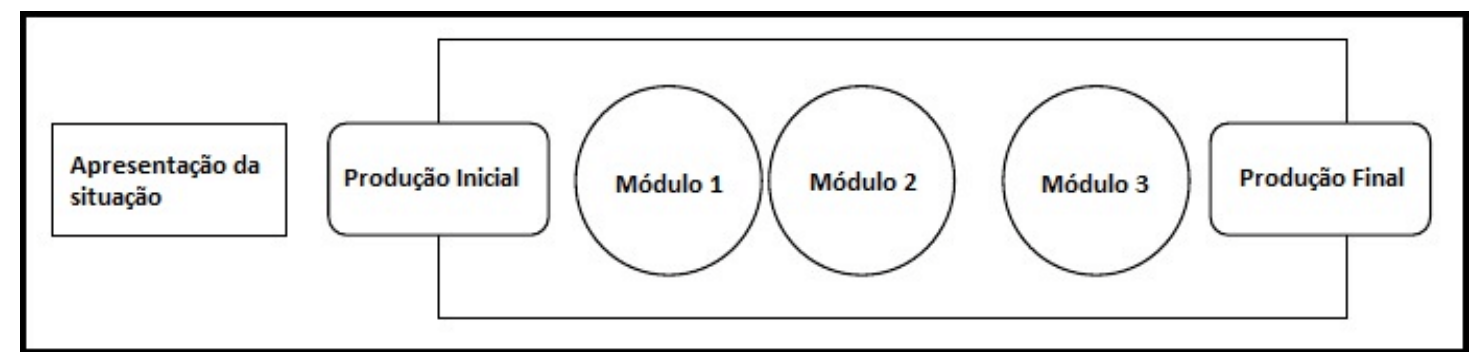

Fonte: DOLZ; NOVERRAZ; SCHNEUWLY, 2004, p. 83.

As atividades desenvolvidas nos módulos podem ser divididas em dois grandes grupos. 0 primeiro envolve a revisão de texto por análise e/ou aplicação. A questão da revisão, típica do ensino de qualquer produção textual, foi problematizada por meio da aplicação das regras, de modo que nas atividades 3 e 8 a revisão da escrita era realizada por meio de sua aplicação prática: os alunos precisavam ler e executar o que era prescrito. Esse tipo de atividade é inerente ao tipo de texto injuntivo: regular ações. Já o segundo grupo consistia em atividades de enriquecimento léxico/semântico e envolveram o uso de dicionário on-line e a reflexão sobre o vocabulário próprio do jogo. Organizamos a referida divisão no organograma abaixo: 


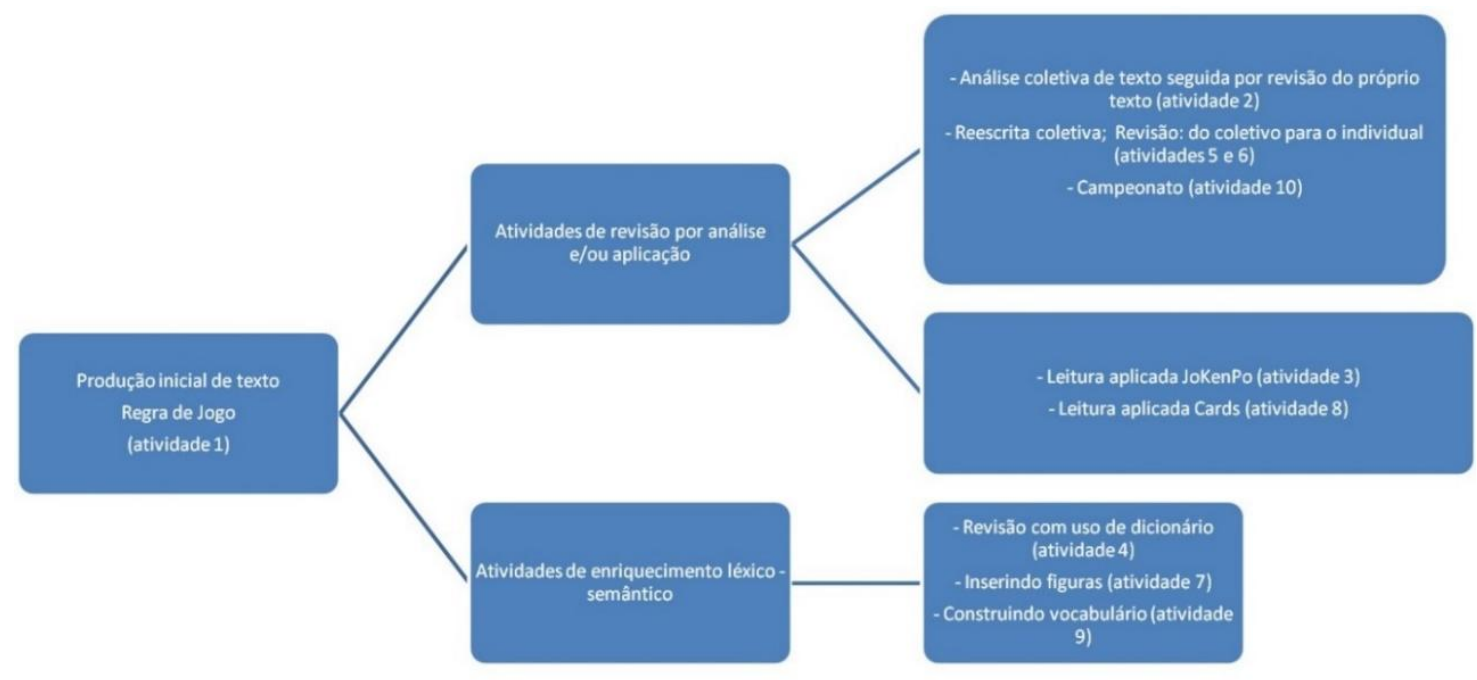




\section{Metodologia, unidades de análise e tratamento do corpus}

Nosso intuito é compreender o processo de produção escrita realizado por crianças do 3o ano do Ensino Fundamental, etapa peculiar na qual os jovens escritores precisam demonstrar que já possuem conhecimentos razoáveis acerca do sistema alfabético e das convenções ortográficas do português brasileiro e, concomitantemente, desenvolver habilidades de produção de textos. Somamos a essa situação a problemática do uso dos instrumentos digitais da escrita - no caso, o computador e o software de edição de texto -, bem como o manejo dos instrumentos periféricos - como o teclado e o mouse -, com o propósito de discutir quais são os novos saberes que emergem na aula de produção de língua materna quando essas ferramentas de escrita são introduzidas. Os dados foram gerados em situações reais de ensino de uma escola pública da cidade de São Paulo, caracterizando uma abordagem qualitativa com foco em uma análise que envolve a interpretação compreensiva por meio da análise de interações situadas. Para tal, nos apoiaremos em Góes (2000), Leal e Luz (2001) e Calil e Pereira (2018), que utilizam a abordagem microgenética em uma perspectiva enunciativa para analisar os comentários feitos por alunos recém-alfabetizados durante a produção de texto em tela.

Apresentando um conjunto de materiais gerados ao longo do processo de produção de texto das duplas, analisaremos o processo de escrita dos alunos, com foco sobre a atividade reflexiva na prática de uso da língua e em relação aos produtos que vão sendo gerados.

\subsection{Abordagem microgenética em uma perspectiva enunciativa}

O recurso à abordagem microgenética se justifica, pois o objetivo central da pesquisa é compreender os processos significativos que se desenvolvem entre os alunos e a tarefa de produção de textos escritos no interior da rotina escolar regular de uma escola pública. A abordagem microgenética tem como um de seus principais elementos de base a importância dada ao caráter situado desses processos em oposição aos processos estudados em circunstâncias descaracterizadas de seu contexto habitual, como, por exemplo, estudos desenvolvidos em laboratório. Os estudos ocupados das microgêneses se interessam 
principalmente pelas significações ou, em outras palavras, pelos conhecimentos locais e contextuais construídos pelos parceiros na interação.

De acordo com Balslev e Saada-Robert (2006), existem quatro premissas para o desenvolvimento dessa abordagem metodológica: a primeira se refere à análise dos processos de coconstrução do conhecimento ou o encadeamento das interações entre os sujeitos no ambiente didático; a segunda delimita o conteúdo dessas interações, ou seja, elas precisam tratar de objetos de ensino relevantes para a situação didática proposta; a terceira envolve a análise da elaboração de significações, cuja função é organizar os conhecimentos prévios e os novos conhecimentos; e, por fim, a quarta é a necessidade dos dados serem gerados em tempos e espaços reais, dado um contexto institucional e cultural definido. No Brasil, Góes utiliza a abordagem microgenética em estudos de aquisição da língua escrita e a define como:

[...] uma forma de construção de dados que requer atenção a detalhes e o recorte de episódios interativos, sendo o exame orientado para o funcionamento dos sujeitos focais, as relações intersubjetivas e as condições sociais da situação, resultando num relato minucioso dos acontecimentos. (GÓES, 2000, p. 9).

Dentre as possibilidades de perspectivas que podem ser assumidas no interior da abordagem microgenética, a perspectiva enunciativo-discursiva é frequentemente a mais adotada por estudos que investigam o processo de aprendizagem de língua materna nos estágios iniciais da escolarização (CALIL, 2016; CALIL; PEREIRA, 2018; LEAL; LUZ, 2001). Assumir uma perspectiva enunciativo-discursiva implica no exame dos processos a partir do ponto de vista do fluxo das enunciações, numa ampliação da noção de diálogo para além dos contatos face a face, e no destaque das práticas sociais, das condições materiais, da posição de poder dos sujeitos, da imagem dos interlocutores, das formações discursivas etc. Caudatárias dessa perspectiva, Leal e Luz, bastante embasadas pelos teóricos da Análise da Conversa, defendem a necessidade de se analisar o discurso produzido na situação de interação em foco.

A concepção de linguagem como processo de interação fornece suporte teórico para os procedimentos metodológicos em que ações verbais são tomadas como objeto de análise. Nessa perspectiva, a linguagem é tomada como um fenômeno situado e os protocolos verbais são manipulados através das análises microgenéticas. (LEAL; LUZ, 2001, p. 32, grifos nossos). 
Além das autoras supracitadas, nos apoiaremos nos estudos desenvolvidos por Calil (2016) e Calil e Pereira (2018), que adotam a abordagem microgenética-enunciativa para analisar os comentários ${ }^{88}$ feitos por alunos recém-alfabetizados durante a produção de texto manuscrito. Retomando alguns estudos desenvolvidos até os anos 2000, os autores apontam que muitas pesquisas ocupadas da aquisição da língua escrita costumam adotar metodologias quantitativas, analisando o conhecimento acerca da língua escrita a partir da análise de pseudopalavras ou palavras inventadas, frases curtas ou pequenos textos, utilizando como instrumentos de coleta ditados, entrevistas ou textos escritos produzidos em sala de aula. A crítica realizada pelos autores incide no fato de que esse tipo de metodologia não permite que se capture o processo de escrita, sendo assim impossível compreender como os escritores novatos enfrentam seus problemas com os diferentes subsistemas, como, por exemplo, de que modo um problema ortográfico se relacionaria com outros subsistemas ou níveis linguísticos, como o uso de letra maiúscula, a divisão de uma palavra no final da linha (translineação), o conhecimento gramatical ou semântico-lexical para escrever palavras homofônicas, entre outros. Desse modo,

[...] para que possamos melhor compreender o desenvolvimento da produção textual em escreventes novatos e suas relações com os componentes que lhe são inerentes, é legítimo valorizar situações reais de escritura e oferecer mecanismos para identificar e analisar as ocorrências desses componentes durante o texto em curso. (CALIL; PEREIRA, 2018, p. 92).

Assim como os autores, tomaremos como unidade de análise o texto dialogal (TD) estabelecido coenunciativamente durante o processo de escrita a dois. De acordo com a definição dos autores:

O TD é por nós identificado em episódios dialogais em que há o reconhecimento e retorno dos escreventes sobre determinado elemento textual, isto é, tudo aquilo que potencialmente pode fazer parte da composição material de um texto, seja a escolha de um nome de personagem, de letra maiúscula, de um sinal de acentuação ou apenas um traço para separar ou dividir uma palavra. (CALIL; PEREIRA, 2018, p. 95).

${ }^{88}$ Calil (2016) justifica o uso do termo "comentário" dado seu amplo escopo semântico, que pode ser explicativo, justificativo ou uma breve dúvida ou observação sobre o elemento linguístico ou textual que está sendo escrito. 
A partir do TD, nos interessa, em um primeiro momento, compreendê-lo textualmente em unidades de significado, ou seja, em unidades que contêm um componente de conhecimento, um objeto de saber próprio da aula de língua materna, como, por exemplo, quando tratam da ortografia de uma palavra ou dos modos de utilização do teclado.

No texto em curso, esse reconhecimento e retorno não se operam a todo instante, mas quando ocorre sobre um determinado elemento textual, alça-o ao estatuto de "objeto" ou, como temos nomeado (CALIL, 2016), transforma o elemento textual em "objeto textual". O que os escreventes falam sobre um objeto textual (OT) reconhecido é tratado como "comentário" referente a este objeto. O comentário enunciado pode contribuir para a manutenção, modificação ou apagamento do OT referido, alterando o texto em curso e, ao mesmo tempo, traçando sua gênese textual. (CALIL; PEREIRA, 2018, p. 95).

O segundo momento consiste em organizar esses comentários acerca dos objetos de saber agrupando um conjunto de unidades de sentido relativas ao mesmo componente do conhecimento (por exemplo, uma série de afirmações relativas ao uso de um sinal de pontuação). O terceiro é baseado em localizar, no interior dos três grandes processos envolvidos na produção escrita - o planejamento, a textualização e a revisão -, como emergem os problemas de escrita e como eles são operados no interior desses processos.

Trabalhando com a produção escrita de crianças recém-alfabetizadas organizadas em díades, os estudos desenvolvidos por Calil (2016) e Calil e Pereira (2018) operam com o reconhecimento de problemas ortográficos e acabam por distingui-los de problemas gráficos. Os autores conseguem realizar essa distinção justamente por acompanharem o processo de escrita por videogravação, e não apenas pela análise das rasuras gráficas. No caso do nosso estudo, por se tratar da análise do processo de escrita em tela, não observaremos problemas com questões relacionadas à grafia das letras ou a questões envolvendo a translineação, pois são problemas vinculados essencialmente à escrita manuscrita. No entanto, ao analisarmos a escrita em tela, observaremos que as crianças apresentarão outros problemas relacionados ao uso do teclado, do mouse e do editor de texto. 


\subsection{Unidades de análise}

Partindo da unidade de análise texto dialogal, o qual se constitui quando há o reconhecimento e o retorno dos escritores sobre um determinado elemento envolvido na produção do texto em tela, configurando um objeto textual (OT), propomos a divisão desses OTs em três grandes classes:

i) OTs relacionados à faceta linguística, ou seja, ao domínio do sistema alfabético de escrita (escrita de palavras) e suas convenções ortográficas. Competência ortográfica.

ii) OTs relacionados às variações de uma palavra em relação ao seu contexto, ou seja, que envolvem conhecimentos mais relacionados às facetas interativa e sociocultural. Competência composicional - processo de geração do texto.

iii) OTs relacionados ao manejo do instrumento de escrita, a saber, o teclado e o editor de texto digital, e aos conhecimentos relativos ao manejo do editor de texto. Competência técnico-gráfica.

\subsection{Tratamento dos dados e corpus analisado}

No trabalho com a análise microgenética enunciativa há a necessidade fundamental do registro audiovisual completo e sem interrupção de, ao menos, uma sessão int egral de trabalho em classe. Neste estudo, registramos por meio de filmagem um conjunto de 18 aulas de 45 minutos cada, envolvendo o trabalho desenvolvido com duas turmas de 30 ano, totalizando pouco mais de 13 horas de gravação. De modo a complementar a análise, convocamos, além do material oriundo dos comentários realizados pelos alunos por meio das transcrições, a descrição das instruções que conformavam a tarefa na qual os alunos estavam engajados, a imagem do processo de produção escrita realizado no momento do comentário e, em alguns casos, apresentaremos também o resultado das produções escritas dos alunos.

A etapa que compreende a delimitação das sequências didáticas acompanhadas ocorreu em momento prévio à etapa das filmagens. Pesquisadora e professoras delimitaram juntas, a 
partir dos documentos oficiais, o objeto de ensino - a saber, a produção de textos escritos do gênero Regra de Jogo - e, nos momentos de planejamento, traçaram as atividades a serem desenvolvidas. Assim, delimitada a grande unidade Sequência Didática, foram definidas quais aulas seriam filmadas.

A partir das filmagens, recorremos ao procedimento de mapeamento dos dados inspirado na organização de uma sinopse, conforme proposto por Cordeiro (2015). A sinopse permite evidenciar a estruturação hierárquica e sucessiva de cada sequência de ensino. 0 objetivo central é descrever as principais partes da sequência e os principais conteúdos abordados, fornecendo indicações sobre o número de aulas que a compõe, a duração e o tipo das atividades propostas, assim como o material utilizado.

Quadro 5 - Quadro sinóptico proposto por Cordeiro (2015)

\begin{tabular}{|c|c|c|c|c|}
\hline $\begin{array}{c}\text { Atividade } \\
\text { escolar }\end{array}$ & $\begin{array}{c}\text { Marcas temporais } \\
\text { (página, tempo, } \\
\text { duração, linhas) }\end{array}$ & $\begin{array}{c}\text { Formas } \\
\text { sociais de } \\
\text { trabalho }\end{array}$ & $\begin{array}{c}\text { Suportes } \\
\text { materiais }\end{array}$ & $\begin{array}{c}\text { Resumo } \\
\text { narrativizado }\end{array}$ \\
\hline
\end{tabular}

As formas sociais de trabalho são indicadas através de letras e símbolo:

I = trabalho individual;

$\mathrm{D}=$ trabalho em díade;

$\mathrm{G}=$ trabalho em grupo;

$Q=$ trabalho sob forma de pergunta-resposta entre o professor e a classe;

$\mathrm{C}=$ correção individual ou em grupo;

$M=$ exposição ou explicação da parte do professor;

? = forma social de trabalho desconhecida.

À proposta de Cordeiro, inserimos dois componentes de análise que norteiam este estudo no campo de "elementos da interação": objeto de ensino e instrumento didático. Para atender às especificidades da interação no ambiente Laboratório de Informática, inserimos o campo "foco da câmera", pois ora o foco era fixo, capturando a interação geral, ora era móvel, 
capturando a interação entre as duplas de trabalho. Abaixo, apresentamos os itens de nossa proposta de mapeamento:

Quadro 6 - Tabela de mapeamento

\begin{tabular}{|c|c|c|c|c|c|c|}
\hline câmera & \multirow[b]{2}{*}{$\begin{array}{l}\text { Evento } \\
\text { Tarefas }\end{array}$} & \multirow{2}{*}{$\begin{array}{c}\text { TEMPO } \\
\text { min'seg" } \\
\text { Arquivo }\end{array}$} & \multicolumn{2}{|c|}{ Elementos da interação } & \multirow{2}{*}{$\begin{array}{c}\text { Forma } \\
\text { social de } \\
\text { trabalho }\end{array}$} & \multirow{2}{*}{$\begin{array}{c}\text { Resumo } \\
\text { narrativizado }\end{array}$} \\
\hline foc & & & $\begin{array}{l}\text { OBJETO DE } \\
\text { ENSINO }\end{array}$ & $\begin{array}{l}\text { INSTRUMENTO } \\
\text { DIDÁTICO }\end{array}$ & & \\
\hline
\end{tabular}

Ao desenvolver os mapeamentos, nosso intuito foi tornar mais claro o que ocorre no interior de cada atividade, de modo a explicitar a articulação entre as etapas da atividade e a organização interacional, norteando quais momentos da aula precisariam ser efetivamente transcritos. Assim, antes de efetuarmos as transcrições, fizemos o mapeamento ${ }^{89}$ de cada uma das aulas registradas por meio de filmagem.

A partir dele, foi possível pontuar o tempo no interior das aulas nas quais a interação em duplas era privilegiada (apontadas com a letra D na coluna "forma de interação"). Delimitados os momentos de interação entre as duplas e apontamos os momentos em que os comentários se voltaram para os OTs desenvolvidos ao longo da tarefa. Assim, no cabeçalho de cada mapeamento é possível identificar a turma, o nome da mídia e o total de tempo a ser transcrito. Pontuados os OTs, procedemos à transcrição ${ }^{90}$ dos trechos nos quais se desenvolveram os comentários das duplas acerca de um objeto de ensino. Em momentos em que foram desenvolvidas discussões coletivas lideradas pelas professoras ou aqueles nos quais os alunos mostraram pouco engajamento nas tarefas propostas fazendo comentários sobre assuntos alheios à situação didática, a transcrição não foi realizada, de modo que pudéssemos nos ater apenas à transcrição dos momentos nos quais se desenvolveram comentários pertinentes dos alunos, trabalhando em duplas, com ou sem a interferência da pesquisadora ou das professoras, acerca de um objeto de ensino foco da aula/tarefa proposta em questão. Tarefas que não envolviam a produção de texto também não foram consideradas.

\footnotetext{
${ }^{89}$ Todos os mapeamentos desenvolvidos estão disponíveis no ANEXO C.

${ }^{90}$ As transcrições estarão disponibilizadas ao longo da análise por meio de tabelas, apresentando os trechos que serão analisados. Em ANEXOS, será possível consultar todos os períodos transcritos, previamente apontados nos mapeamentos.
} 
Abaixo, apresentamos o quadro síntese com os dados transcritos que serão analisados no próximo capítulo. A primeira coluna se refere à turma acompanhada. A segunda especifica o número e o nome da atividade. A terceira apresenta a sigla $A(+)$ - em que " $A$ " significa "aluno" e a letra subsequente representa a inicial de seu nome - e uma breve informação sobre o desenvolvimento de escrita do aluno em questão - vale ressaltar que as duplas eram organizadas de acordo com as determinações da professora. A quarta delimita em qual operação da produção escrita o OT emergiu. E, por fim, a última coluna identifica a natureza do problema de acordo com as unidades de análise que explicitamos na seção 7.2.

Quadro 7 - Relação de duplas, nível de proficiência, operação de produção textual e objeto textual

\begin{tabular}{|c|c|c|c|c|}
\hline Turma & Atividade & Dupla/Nível alfa & Operação & Objeto textual \\
\hline \multirow{3}{*}{$3 \circ A$} & \multirow{3}{*}{$\begin{array}{l}\text { 1. Produção } \\
\text { inicial }\end{array}$} & \multirow{3}{*}{$\begin{array}{l}\text { AL - razoável } \\
\text { domínio de } \\
\text { escrita } \\
\text { AS - dificuldades } \\
\text { de escrita }\end{array}$} & Planejamento & $\begin{array}{l}\text { Composicional: formula o } \\
\text { texto oralmente, mas não } \\
\text { redige. }\end{array}$ \\
\hline & & & Textualização & $\begin{array}{l}\text { Composicional: função } \\
\text { sintática da palavra. }\end{array}$ \\
\hline & & & Revisão & $\begin{array}{l}\text { Composicional: concordância } \\
\text { verbal. }\end{array}$ \\
\hline \multirow{3}{*}{$3 \circ \mathrm{C}$} & \multirow{3}{*}{$\begin{array}{l}\text { 1. Produção } \\
\text { inicial }\end{array}$} & \multirow{3}{*}{$\begin{array}{l}\text { ARA - } \\
\text { dificuldades de } \\
\text { escrita } \\
\text { ALU - } \\
\text { dificuldades de } \\
\text { escrita }\end{array}$} & \multirow{3}{*}{ Textualização } & $\begin{array}{l}\text { Técnico-gráfico: } \\
\text { - alternar linhas; } \\
\text { - deletar letras. }\end{array}$ \\
\hline & & & & $\begin{array}{l}\text { Ortográfico: } \\
\text { - redigir palavras com } \\
\text { sílabas não canônicas; } \\
\text { - } \text { segmentação. } \\
\end{array}$ \\
\hline & & & & $\begin{array}{l}\text { Ortográfico: apoio na } \\
\text { oralidade. }\end{array}$ \\
\hline \multirow{6}{*}{$3 \circ B$} & \multirow{6}{*}{$\begin{array}{l}\text { 2. Revisão } \\
\text { coletiva e } \\
\text { produção } \\
\text { escrita }\end{array}$} & \multirow{6}{*}{$\begin{array}{l}\text { AB - razoável } \\
\text { domínio de } \\
\text { escrita } \\
\text { AV - dificuldades } \\
\text { de escrita }\end{array}$} & Planejamento & $\begin{array}{l}\text { Composicional: Organização } \\
\text { das informações do texto } \\
\text { injuntivo. }\end{array}$ \\
\hline & & & \multirow{5}{*}{ Textualização } & Ortográfico: segmentação. \\
\hline & & & & $\begin{array}{l}\text { Técnico- gráfico: marcações } \\
\text { do corretor automático do } \\
\text { editor de texto. }\end{array}$ \\
\hline & & & & $\begin{array}{l}\text { Composicional: estrutura } \\
\text { frasal. }\end{array}$ \\
\hline & & & & $\begin{array}{l}\text { Ortográfico: escrita de palavra } \\
\text { desconhecida. }\end{array}$ \\
\hline & & & & $\begin{array}{l}\text { Composicional: inserção de } \\
\text { novas informações no texto. }\end{array}$ \\
\hline
\end{tabular}




\begin{tabular}{|c|c|c|c|c|}
\hline $30 \mathrm{~B}$ & $\begin{array}{l}\text { 2. Revisão } \\
\text { coletiva e } \\
\text { produção } \\
\text { escrita }\end{array}$ & $\begin{array}{l}\text { AO - razoável } \\
\text { domínio de } \\
\text { escrita } \\
\text { AT - razoável } \\
\text { domínio de } \\
\text { escrita }\end{array}$ & Textualização & $\begin{array}{l}\text { Composicional: estrutura da } \\
\text { frase. }\end{array}$ \\
\hline \multirow[t]{3}{*}{$3 \circ \mathrm{C}$} & \multirow{3}{*}{$\begin{array}{l}\text { 2. Revisão } \\
\text { coletiva e } \\
\text { produção } \\
\text { escrita }\end{array}$} & \multirow{3}{*}{$\begin{array}{l}\text { ALA - razoável } \\
\text { domínio de } \\
\text { escrita } \\
\text { AR - dificuldades } \\
\text { de escrita }\end{array}$} & \multirow[t]{3}{*}{ Textualização } & $\begin{array}{l}\text { Composicional: } \\
\text { paragrafação/pontuação e } \\
\text { organização sintática (apoio } \\
\text { na oralidade). }\end{array}$ \\
\hline & & & & $\begin{array}{l}\text { Técnico-gráfico: passagem de } \\
\text { linha. }\end{array}$ \\
\hline & & & & Ortográfico: segmentação. \\
\hline \multirow[b]{2}{*}{$3 \circ \mathrm{C}$} & \multirow{2}{*}{$\begin{array}{l}\text { 6. Do coletivo } \\
\text { para o } \\
\text { individual }\end{array}$} & \multirow{2}{*}{$\begin{array}{l}\text { ALF - razoável } \\
\text { domínio de } \\
\text { escrita } \\
\text { AK - dificuldades } \\
\text { de escrita }\end{array}$} & \multirow[b]{2}{*}{ Revisão } & Ortográfico: segmentação. \\
\hline & & & & $\begin{array}{l}\text { Técnico-gráfico: } \\
\text { posicionamento do cursor } \\
\text { (manejo do mouse). }\end{array}$ \\
\hline \multirow{5}{*}{$30 \mathrm{~B}$} & \multirow{5}{*}{$\begin{array}{l}\text { 6. Do coletivo } \\
\text { para o } \\
\text { individual }\end{array}$} & \multirow{5}{*}{$\begin{array}{l}\text { AGO - razoável } \\
\text { domínio de } \\
\text { escrita } \\
\text { AW -dificuldades } \\
\text { de escrita }\end{array}$} & \multirow[b]{2}{*}{ Textualização } & Ortográfico: homofonia. \\
\hline & & & & $\begin{array}{l}\text { Técnico-gráfico: corretor } \\
\text { automático do editor de } \\
\text { texto. }\end{array}$ \\
\hline & & & \multirow{3}{*}{ Revisão } & $\begin{array}{l}\text { Composicional: estrutura da } \\
\text { frase. }\end{array}$ \\
\hline & & & & $\begin{array}{l}\text { Ortográfico: uso do R na } \\
\text { forma infinitiva do verbo. }\end{array}$ \\
\hline & & & & $\begin{array}{l}\text { Técnico-gráfico: inserção de } \\
\text { diacrítico. }\end{array}$ \\
\hline $3 \circ \mathrm{C}$ & $\begin{array}{l}\text { 7. Inserindo } \\
\text { figuras }\end{array}$ & $\begin{array}{l}\text { AE - razoável } \\
\text { domínio de } \\
\text { escrita } \\
\text { AG -razoável } \\
\text { domínio de } \\
\text { escrita }\end{array}$ & $\begin{array}{l}\text { Textualização/ } \\
\text { Diagramação }\end{array}$ & $\begin{array}{l}\text { Técnico-gráfico: } \\
\text { - paginação; } \\
\text { - rolagem; } \\
\text { - formatação de figuras. }\end{array}$ \\
\hline
\end{tabular}

\subsection{Normas de transcrição}

Para realizarmos a transcrição do corpus, nos valemos das normas estabelecidas pelo Projeto de Estudo da Norma Linguística Urbana Culta, conhecido como "Projeto Nurc" (PRETI, 2003), focado no estudo da modalidade oral da língua, abordando problemas como o turno e suas estratégias de gestão, as leis de simetria na conversação natural, os procedimentos de 
reformulação, o emprego de sinais característicos da língua oral (marcadores conversacionais), entre outras marcas, com o intuito de tornar visíveis as especificidades da língua falada. Abaixo, explicitaremos o quadro com as normas para transcrição.

Quadro 8 - Normas de transcrição ${ }^{91}$

\begin{tabular}{|l|c|}
\hline \multicolumn{1}{|c|}{ OCORRÊNCIA } & SINAIS \\
\hline Incompreensão de palavras ou segmentos & ( ) \\
\hline Hipótese do que se ouviu & (hipótese) \\
\hline Truncamento & maiúscula \\
\hline Entonação enfática & :::: \\
\hline Prolongamento de vogal ou consoante (como S, R) & ? \\
\hline Silabação & $\ldots$ \\
\hline Interrogação & ((minúscula)) \\
\hline Qualquer pausa & -- -- \\
\hline Comentários descritivos do transcritor & ligando \\
\hline $\begin{array}{l}\text { Comentários que quebram a sequência temática da exposição; } \\
\text { desvio temático }\end{array}$ & [ linhas \\
\hline $\begin{array}{l}\text { Superposição, simultaneidade de vozes } \\
\text { Indicação de que a fala foi tomada ou interrompida em } \\
\text { determinado ponto }\end{array}$ & (...) \\
\hline Citações literais ou leituras de textos & " " \\
\hline
\end{tabular}

Para identificação dos interlocutores, utilizaremos a letra A mais a inicial do nome do aluno. Quando houver participação das professoras, utilizaremos a letra P mais a letra inicial do nome da professora. Caso haja coincidência das iniciais dos nomes, utilizaremos duas letras para um dos interlocutores.

\footnotetext{
91 Além dos itens elencados no quadro: não são usadas iniciais maiúsculas em início de turnos ou demais segmentos; iniciais maiúsculas são utilizadas apenas para nomes próprios ou siglas; números são grafados por extenso; não se indica o ponto de exclamação. Os sinais apresentados no quadro podem ser combinados, como, por exemplo, "/oh:::..../" indicando alongamento e pausa. Não se utilizam sinais de pausa, típicos da língua escrita, como ponto-e-vírgula, dois-pontos e vírgula. As reticências marcam qualquer tipo de pausa.
} 


\section{Análise}

De modo a preservar a lógica da sequência didática acompanhada, apresentaremos a análise conforme a organização cronológica na qual os dados foram gerados. Como ao longo das tarefas os alunos estão engajados na produção de um mesmo texto, envolvendo diferentes módulos da sequência prevista, poderemos acompanhar o desenvolvimento didático. A análise está organizada da seguinte maneira: o primeiro trecho do tópico faz uma breve descrição da atividade proposta aos alunos; a seguir, em cada um dos subtópicos, apresentamos o trabalho de cada uma das duplas, iniciando com uma breve descrição acerca das tarefas desempenhadas por cada participante, ou seja, quem dita (o ditante) e quem redige (o escriba); na sequência, são disponibilizadas as tabelas de transcrição e fotos de cada OT explicitado na tabela.

\subsection{Desenvolvimento da produção inicial (atividade 1)}

A tarefa proposta aos alunos é a produção inicial da regra do "Jogo dos Cards". Nessa aula é criada uma base geral de orientação comunicativa, na qual os alunos são convidados a redigir a regra desse jogo, bastante conhecido por eles, com o intuito de ajustarem alguns pontos e construírem uma regra clara e coerente.

\subsubsection{Trabalho da dupla AL e AS}

Neste primeiro trecho, analisaremos o momento em que a dupla AL (maior domínio da escrita) e AS (menor domínio da escrita) é abordada pela professora após os primeiros minutos da consigna inicial. A professora se aproxima deles e realiza a leitura do que eles já escreveram (Figura 7). 
Quadro 9 - Transcrição do OT composicional de AL/AS:

formula o texto oralmente, mas não redige, e função sintática da palavra

\begin{tabular}{|c|c|c|c|}
\hline Tempo & Linha & Interlocutor & Transcrição \\
\hline \multirow[t]{3}{*}{$11^{\prime} 16^{\prime \prime}$} & 20 & PC & E aí depois vamos lá "você tem que..." ((lê o texto na tela)) \\
\hline & 21 & $\mathrm{AL}$ & [ bater na card para virar a card \\
\hline & 22 & PC & Ah::: esse é o objetivo do jogo? \\
\hline $11^{\prime} 22^{\prime \prime}$ & 23 & $\mathrm{AL}$ & $\begin{array}{l}\text { É você virar as duas cards tipo:: você tem que virar as duas cards... tipo } \\
\text { você aposta quantas cards você quer aí o outro aposta o mesmo } \\
\text { número aí quem falar primeiro vai aí tipo você bate aí que virar as duas } \\
\text { tipo que virar todas as cards e você vira a última tipo é tudo seu.. tipo } \\
\text { você ganha/ só que você tem que bater em cima ((faz gestos com as } \\
\text { mãos para exemplificar)) assim ou assim }\end{array}$ \\
\hline \multirow[t]{4}{*}{$11^{\prime} 48^{\prime \prime}$} & 24 & PC & $\begin{array}{l}\text { Entendi... AL então vamos escrever tudo isso aí que você colocou por } \\
\text { que são coisas importantes não são? ((professora se afasta)) }\end{array}$ \\
\hline & 25 & $\mathrm{AL}$ & [que eu acabei de dizer? \\
\hline & 26 & PC & É \\
\hline & 27 & AS & ( ) ((alunos escrevem)) \\
\hline \multirow[t]{3}{*}{$12^{\prime} 00^{\prime \prime}$} & 28 & $\mathrm{AL}$ & Trapacear ou trapaça? \\
\hline & 29 & AS & ó pro... ((aponta a tela)) \\
\hline & 30 & $\mathrm{AL}$ & "Não pode trapa/ ((lê o texto que acabou de digitar)) \\
\hline
\end{tabular}

Os alunos iniciam a produção do texto listando os comportamentos considerados inadequados no decorrer do jogo, "não vale" e "não pode" (Figura 7), o que configura uma característica dos textos instrucionais, apresentando frases iniciadas por verbos que direcionam a ação do leitor indicando o que deve e o que não deve ser feito (MARINELLO; BOFF; KOCHE, 2008).

Figura 7 - AL/AS: Produção de texto inicial

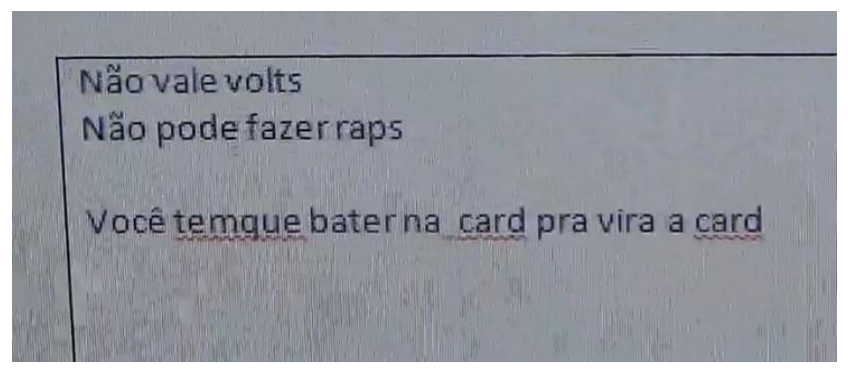

Para compor essa lista, observamos que os alunos utilizaram termos próprios do jogo, mas sem explicitá-los. Essa característica se deve, provavelmente, à imagem mental que os 
autores têm de seus interlocutores, deixando de explicar aquilo que Ihes parece sabido ou que acreditam que se possa deduzir com facilidade. Com o intuito de auxiliá-los a dar prosseguimento à produção escrita, a professora os questiona sobre a sentença "Você tem que bater na card para vira a card" e se ela representa o objetivo do jogo (linha 22); a seguir, um dos alunos explica oralmente, realizando uma espécie de planejamento oral do texto (linha 23). A interferência da professora no processo de escrita atuou de modo a solicitar mais informações sobre como o jogo deve ser executado, no que $A L$ demonstrou ter conhecimento elaborando o texto oralmente (linha 23), e solicita que esse conteúdo seja integrado no texto (linha24). No entanto, apesar da solicitação feita pela professora, os alunos retomam a produção dando continuidade à listagem de comportamentos inadequados para o desenvolvimento do jogo. Nesse processo de textualização, surge uma questão ortográfica em torno do uso do substantivo "trapaça" (linha 28) ou do verbo "trapacear" (Figura 8), que é ignorada pelo colega, e, assim, seguem com a escrita.

Figura 8 - AL/AS: Textualização/OT composicional - função sintática da palavra

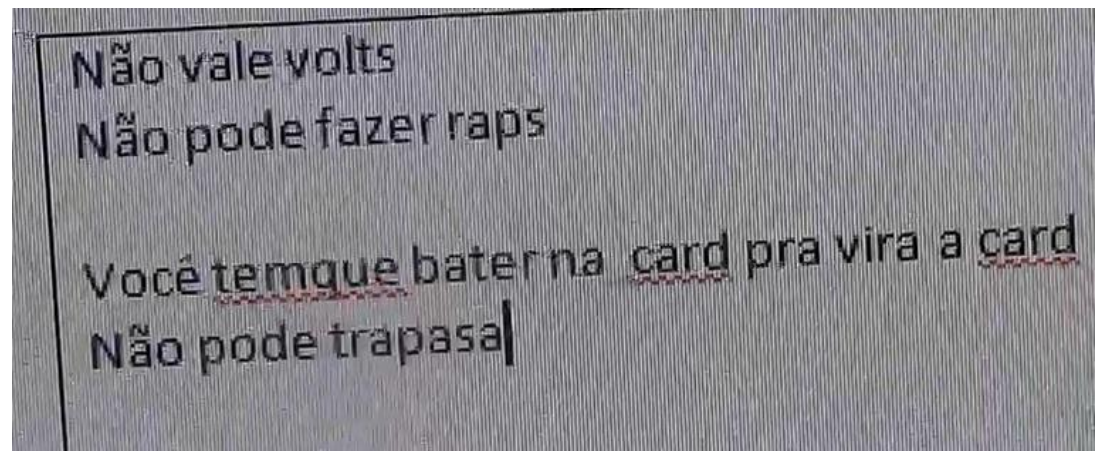

Quadro 10 - Transcrição do OT composicional de AL/AS: concordância verbal

\begin{tabular}{|c|c|c|l|}
\hline Tempo & Linha & Interlocutor & Transcrição \\
\hline $12^{\prime} 51^{\prime \prime}$ & 31 & $\mathrm{AS}$ & "Exemplo"? ((lê o texto na tela)) \\
\hline & 32 & $\mathrm{AL}$ & ((digita no teclado)) \\
\hline $13^{\prime} 20^{\prime}$ & 33 & $\mathrm{AS}$ & ((Lê em voz baixa)) pronto \\
\hline & 34 & $\mathrm{AL}$ & $\begin{array}{l}\text { ( ) é a parte mais ( ) "não pode trapacear por exemplo você tá ba/ } \\
\text { batendo/do }\end{array}$ \\
\hline & 35 & $\mathrm{AS}$ & Do/do e distraí/ \\
\hline & 36 & $\mathrm{AL}$ & Não... espera... "está batendo e distra/ \\
\hline
\end{tabular}




\begin{tabular}{|c|c|c|c|}
\hline $13^{\prime} 40^{\prime \prime}$ & 37 & AS & \multicolumn{1}{c|}{ ["Tá baten/? Tá bate? } \\
\hline & 38 & AL & $\begin{array}{l}\text { "Tá batendo e distrai ele e ele vira e você vira a card sem bater na } \\
\text { card" ... é mais ou menos isso deixa eu arrumar aqui que eu fiz errado } \\
\text { ((apaga a palavra 'bater' e escreve novamente)) }\end{array}$ \\
\hline
\end{tabular}

Figura 9 - AL/AS: OT composicional (concordância verbal)

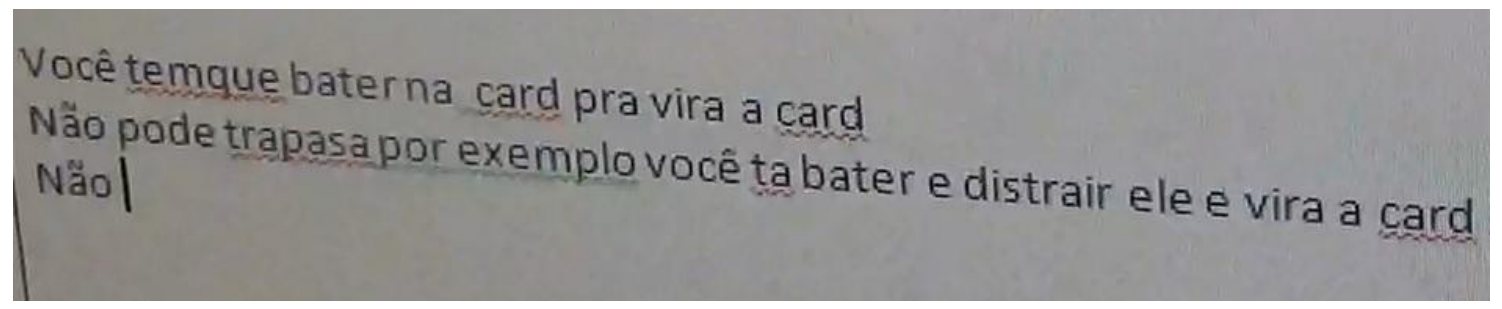

Ao ler o trecho que acabara de escrever, AL realiza correções apenas oralmente, substituindo o substantivo "trapaça" pelo verbo em sua forma infinitiva, "trapacear" (linha 34), no entanto, não realiza nenhuma alteração no texto escrito. No mesmo processo de revisão, percebe que utilizou o verbo "bater" em sua forma no infinitivo, no entanto, a concordância no contexto exigiria que a palavra estivesse grafada no gerúndio, devendo ser formada pelo sufixo ndo.

Analisando os OTs suscitados nessa interação, observamos aspectos de duas naturezas vinculadas a competência composicional, tanto discursiva quanto gramatical. No caso discursivo, houve a interferência da professora, solicitando que tornassem as prescrições do jogo mais explícitas, ou seja, que desenvolvessem mais a determinação do texto injuntivo (TRAVAGLIA, 1991). As crianças recém-alfabetizadas ainda estão em processo de desenvolvimento da configuração do lugar do leitor.

A elevação de formas de ação, na escrita, é desencadeada pelo reconhecimento explícito do caráter dialógico do ato de escrever, que leva o sujeito a considerar de modo deliberado o leitor e o texto, num processo provavelmente longo. (GÓES, 1993, p. 113).

Ou seja, é necessário que haja o desenvolvimento de uma postura reflexiva sobre a produção escrita, de modo que compreenda a língua escrita como forma de interação. É nesse ponto que se desenvolvem as consciências pragmática - que envolve a relação entre a língua escrita e o contexto em que ela é usada - e metatextual - que envolve o desenvolvimento de 
estratégias para ser compreendido (SOARES, 2016, p. 140). No entanto, a partir da interferência da professora, na quarta frase desenvolvida no texto, observa-se que os alunos buscam explicitar o que configura uma "trapaça", o que não ocorreu nas duas primeiras frases.

Os OTs composicionais são vinculados à grafia das palavras em relação ao contexto, como em "trapaça/trapacear" e "bater/batendo". No primeiro caso, o aluno coloca sua dúvida no decorrer da textualização, ou seja, ela não surgiu em um momento de retorno ao texto. Como o comentário foi ignorado pelo colega, AL optou por utilizar o substantivo "trapaça", pois seu objetivo era definir, delimitar o que configurava uma transgressão no decorrer do jogo. Já o comentário sobre o problema de concordância verbal "está bater" (linhas 34 a 38) focalizado pelos dois alunos, ocorre em um retorno ao texto: após finalizar a escrita da frase, AL lê o trecho em voz alta e observa que há algum problema com a forma "tá bater". Os dois alunos enunciam a terminação em gerúndio "do, do, do", o que leva ao movimento de correção: AL deleta a palavra. No entanto, é curioso que a forma no infinitivo é mantida, conforme pode ser observado na versão final do texto:

Não vale volts

Não pode fazer raps

Você temque bater na card pra vira a card

Não pode trapasa por exemplo você ta bater e distrair ele e vira a card sem bater na card Não pode fazer grudis exemplo você bate uma card e gruda na sua mao Voce poder bater mao sinhá ou bafao o vents na card

AL/AS - Produção de texto 1ạ versão

\subsubsection{Trabalho da dupla ALU e ARA}

A dupla que participa da interação abaixo é composta por dois alunos alfabetizados, mas que apresentam grandes dificuldades na escrita de palavras. No que tange ao manejo dos instrumentos digitais de escrita, ALU apresenta mais familiaridade com os comandos básicos do 
editor de texto. A professora havia estabelecido que ARA desempenhasse o papel de escriba e que ALU desempenhasse o papel de ditante, no entanto, os papéis se alternam, pois ALU manifesta o desejo de utilizar o teclado, e ARA o consente. No desenvolvimento da tarefa proposta, a escrita das regras do "Jogo dos Cards", a dupla se mostrou muito engajada e apenas solicitou auxílio da professora quando ela se colocou próxima do seu computador e fez a leitura do que já haviam produzido:

Quadro 11 - Transcrição do OT técnico-gráfico de ARA/ALU: alternar linhas e deletar letras

\begin{tabular}{|c|c|c|c|}
\hline Tempo & Linha & Interlocutor & Transcrição \\
\hline $22^{\prime} 20^{\prime \prime}$ & 96 & ARA & $\begin{array}{l}\text { Te::m te::m teinque:::ba::: } \quad(\quad \text { ) ((aluna escreve soletrando } \\
\text { letra por letra)) }\end{array}$ \\
\hline \multirow[t]{10}{*}{$233^{\prime} 00^{\prime \prime}$} & 97 & ALU & Que que você tá fazendo? \\
\hline & 98 & ARA & $\begin{array}{l}\text { Ah eu coloquei o A no lugar do E.... só:::: uma::: vê::: ((escreve e } \\
\text { soletra)) tenta me ajudar... cadê o Z ? }\end{array}$ \\
\hline & 99 & ALU & Você que tá escrevendo eu não to entendendo nada \\
\hline & 100 & ARA & Só consegui fazer isso professora \\
\hline & 101 & $\mathrm{PE}$ & Tá muito bom lê o que você já escreveu AR \\
\hline & 102 & ARA & Ai professora era pra eu tirar esse N por que eu escrevi "as na" \\
\hline & 103 & ALU & Ah então tira \\
\hline & 104 & $\mathrm{PE}$ & Você quer tirar o N? Você sabe Lucas como é que tira o N? \\
\hline & 105 & ALU & ((aluno faz a correção)) \\
\hline & 106 & $\mathrm{PE}$ & Oh:: muito bem \\
\hline \multirow[t]{5}{*}{$23^{\prime} 57^{\prime \prime}$} & 107 & ARA & $\begin{array}{l}\text { Oh:: na/ "as acartas teiquibarte soumaves" ((lê, passando o } \\
\text { dedo na tela)) }\end{array}$ \\
\hline & 108 & PE & $\begin{array}{l}\text { Muito bem Raissa... então isso é uma regra do jogo? Só pode } \\
\text { bater uma vez? }\end{array}$ \\
\hline & 109 & ARA & $\begin{array}{ll}\text { vezes a pessoa perde } & \text { [aí porque porque se bater duas }\end{array}$ \\
\hline & 110 & ALU & $\begin{array}{l}\text { [mas se alguém falar bate dois } \\
\text { bafão pode bater dois.... Perde a vez e a outra pessoa vai duas } \\
\text { vezes também... }\end{array}$ \\
\hline & 111 & $\mathrm{PE}$ & Ah vocês têm que explicar isso \\
\hline
\end{tabular}

Como é possível observar, os alunos com pouco domínio da faceta linguística apresentam muitas dúvidas na escrita de palavras. Podemos apontar problemas para registrar nasalização (linha 96), resquícios de estrutura silábica (linha 98) e segmentação (linha 102). 0 registro pode ser observado na figura abaixo: 
Figura 10 - ARA/ALU: Produção de texto inicial

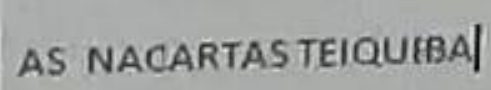

Desde o início da interação, ARA mostra dificuldades em encontrar as letras no teclado. O primeiro OT que emerge na situação é a inserção de uma letra extra, a letra N, que ARA grafa, mas não sabe como deletá-la. Provavelmente, o equívoco é decorrente ou de uma alteração do planejamento no momento da textualização - ARA poderia ter pensado em utilizar a contração "na" em lugar do artigo definido - ou foi um mero erro de digitação. Com a mediação da professora, ALU apaga da letra, mostrando-se capaz de posicionar o mouse e acionar o comando correto (linha 105). Após a correção, ARA realiza a leitura, fazendo o acompanhamento com o dedo na tela.

Figura 11 - ARA/ALU - Continuação da produção de texto

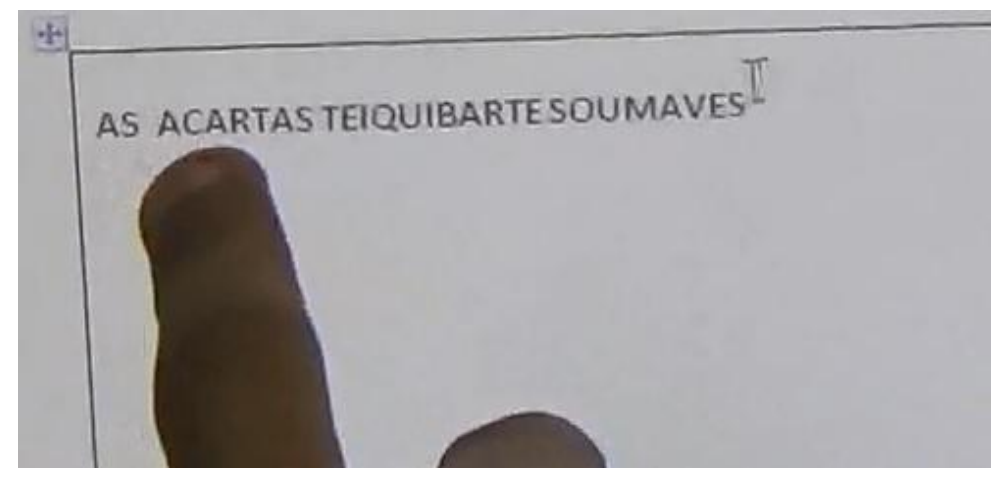

Após a leitura, ARA tenta continuar a produção textual, mas esbarra em outro problema técnico: mudar de linha, configurando um segundo OT relacionado à usabilidade do teclado. Novamente, o problema é resolvido por AL:

Quadro 12 - Transcrição do OT técnico-gráfico de ARA/ALU: alternar linhas e deletar letras

\begin{tabular}{|c|c|c|l|}
\hline Tempo & Linha & Interlocutor & Transcrição \\
\hline $24^{\prime} 15^{\prime \prime}$ & 112 & ARA & [professora::: como \\
\hline & 113 & PE & Você quer mudar de linha? Qual tecla que/ \\
\hline & 114 & ARA & [como que vai pra baixo \\
\hline & 115 & ALU & ((aluno mostra a tecla Enter no teclado)) \\
\hline
\end{tabular}


Na sequência, os alunos seguem o processo de textualização, no qual emergem diversas questões voltadas a problemas ortográficos lexicais, como a nasalização na grafia de "quem" e o uso do R no infinitivo do verbo "bater", o que assinala a dificuldade em grafar sílabas não canônicas, como é possível constatar na interação abaixo:

Quadro 13 - Transcrição do objeto textual ortográfico de ARA/ALU: redigir palavras com sílabas não canônicas

\begin{tabular}{|c|c|c|l|}
\hline Tempo & Linha & Interlocutor & Transcrição \\
\hline $25^{\prime} 00^{\prime \prime}$ & 123 & ALU & Olha o que você fez \\
\hline & 124 & ARA & aí QUE-IM aí tem um I... não assim tá QUE-NI/ queni... espaço \\
\hline & 125 & ALU & ((aluno digita)) \\
\hline & 126 & ARA & Tá junto \\
\hline & 127 & ALU & Deixa que eu faço ((aluna está apertando a tecla Backspace)) \\
\hline & 128 & ARA & Ba:::: ter.... tá errado \\
\hline & 129 & ALU & B - A \\
\hline & 130 & ARA & O T e o E \\
\hline & 131 & ALU & Não tem um R no meio né professora? \\
\hline & 132 & PE & BATER tem um R no meio? \\
\hline & 133 & ARA & Ba:::: ((aluna pensativa)) \\
\hline & 134 & PE & Óh BA-TER::: \\
\hline $25^{\prime} 40^{\prime \prime}$ & 135 & ARA & Ah é no final... daí o R ((aponta a tela com o texto)) \\
\hline & 136 & PE & O R onde? No finalzinho... muito bem \\
\hline & 137 & ARA & “que/quem bater" \\
\hline
\end{tabular}

Continuando a produção, mais um problema ortográfico lexical emerge: os alunos redigem a palavra "vez" em dois momentos. No primeiro, utilizam a forma "ves"; já na segunda ocorrência, digitam "veis" (Figura 12). Observando o modo como digitaram na segunda ocorrência, AR retoma a primeira e aponta que necessita de correção: "tem um I aqui" (linha 144). Observamos nesse OT um forte apoio na oralidade no processo de escrita de palavras por essas crianças.

Quadro 14 - Transcrição do OT ortográfico de ARA/ALU: apoio na oralidade

\begin{tabular}{|c|c|c|l|}
\hline Tempo & Linha & Interlocutor & Transcrição \\
\hline & 142 & ARA & $\begin{array}{l}\text { “PE:::r" o D e o E ((aluna dita enquanto o colega digita)) "PE::rde a } \\
\text { veiz/ a velZ" }\end{array}$ \\
\hline & 143 & ALU & Duas vê:::iz \\
\hline & 144 & ARA & $\begin{array}{l}\text { Olha aqui a gente colocou “duas ves" ((aponta a palavra na tela)) então } \\
\text { aqui ó tem um 'i'... tem um /i/ aqui }\end{array}$ \\
\hline
\end{tabular}




\begin{tabular}{|c|c|c|l|}
\hline & 145 & ALU & $\begin{array}{l}\text { Professora como faz pra voltar? ((o aluno posiciona o cursor no local } \\
\text { indicado pela aluna mas acaba mudando de linha)) }\end{array}$ \\
\hline & 146 & PE & Pra voltar é só apertar essa tecla aqui ó ((aponta a tecla Backspace)) \\
\hline 147 & ARA & Eu não sei mais fazer.. por que:: é:::: \\
\hline
\end{tabular}

Figura 12 - ARA/ALU: Problema ortográfico lexical

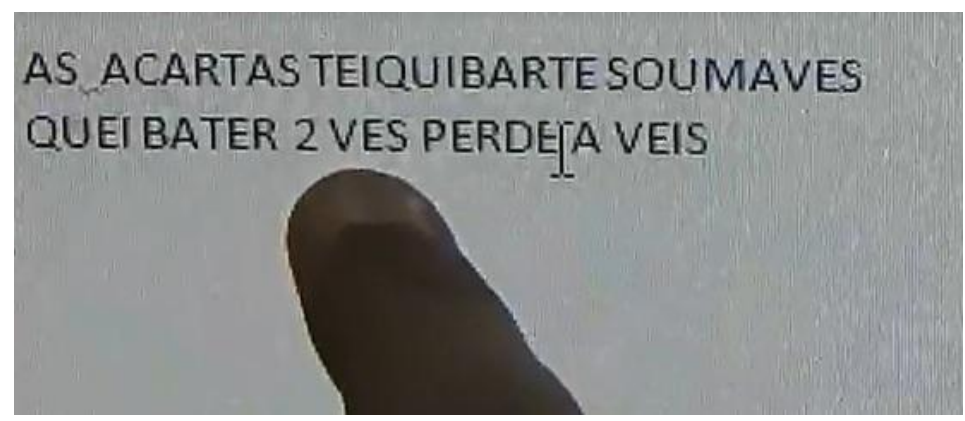

O colega ALU concorda e posiciona o cursor do mouse para inserir a letra que julgavam estar faltando. No entanto, após inserir a letra I, acaba acionando a tecla Enter, o que gera um novo problema técnico que os alunos não conseguem resolver sozinhos e solicitam o auxílio da professora (Figura 13).

Figura 13 - ARA/ALU: Problema técnico-gráfico - mudança de linha

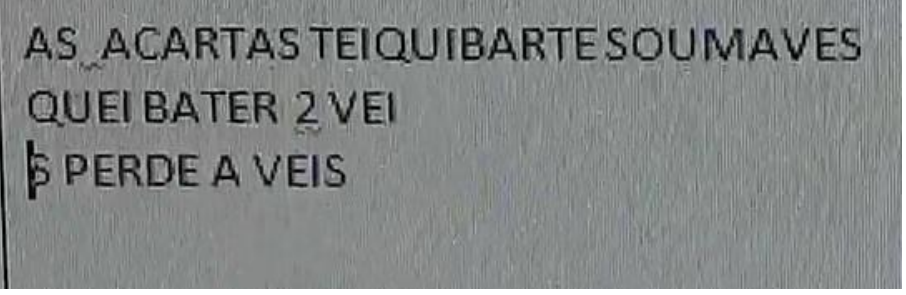

Conforme podemos observar, ARA e ALU, apresentando pouca familiaridade tanto com a escrita de palavras quanto com o manejo do teclado, apresentaram OTs voltados a problemas técnicos de usabilidade do instrumento, como: ir para a próxima linha, retornar para a linha anterior e deletar letra digitada inadequadamente. Os outros OTs observados são de natureza ortográfica. A cada palavra que apresenta sílabas não canônicas os estudantes precisam se concentrar em resolver o problema, distanciando-os do processo de produção do texto em si. 
A interação acompanhada é um exemplo de como alunos recém-alfabetizados ainda não desenvolveram automatismos básicos relacionados tanto à escrita ortográfica de palavras quanto ao manejo dos instrumentos de escrita, no caso, do teclado e do editor de texto Word.

\subsection{Revisitando o texto pela primeira vez (atividade 2)}

A aula é iniciada com a análise coletiva de um texto produzido por um aluno na aula anterior. Após realizarem uma leitura em voz alta, são efetuadas algumas edições no texto, de modo a destacar elementos vinculados à progressão textual, com foco em coesão e coerência. Apesar de não ser o objetivo da aula, as marcações da correção automática do editor de texto emergem na interação coletiva e, por conta disso, alunos e professoras realizam coletivamente algumas correções, especialmente vinculadas à segmentação de palavras e a adequações ortográficas. Finda a revisão coletiva, os alunos são convidados a retomar o texto iniciado na aula anterior, realizar a leitura e fazer as modificações necessárias, bem como dar continuidade à produção de texto.

\subsubsection{Trabalho da dupla $A B$ e $A V$}

O trecho abaixo é a transcrição dos comentários realizados por $A B$, no papel de ditante, e AV, no papel de escriba, engajados em uma atividade de revisão e continuação da produção textual de uma regra de jogo. O texto em questão começou a ser redigido na aula anterior (Figura 14). Assim, AB e AV iniciam sua tarefa:

Quadro 15 - Transcrição do objeto textual composicional de AB/AV:

organização das informações no texto injuntivo

\begin{tabular}{|c|c|c|l|}
\hline Tempo & linha & Interlocutor & Transcrição \\
\hline $08^{\prime} 55^{\prime \prime}$ & 04 & $\mathrm{AB}$ & Vamo lá vai... escreve aí... esCREVE \\
\hline & 05 & $\mathrm{AV}$ & Eu num sei... agora é três? \\
\hline & 06 & $\mathrm{AB}$ & Olha apaca o um/apaga o um... apaga o um \\
\hline
\end{tabular}

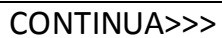




\begin{tabular}{|c|c|c|c|}
\hline & 07 & AV & Pra quê? \\
\hline & 08 & $A B$ & Apaga \\
\hline & 09 & AV & Pra que? \\
\hline & 10 & $A B$ & Esquecemos de colocar uma coisa... apaga... APAga \\
\hline & 11 & AV & ((realiza a modificação deletando o número 1 do texto)) \\
\hline & 12 & $A B$ & $\begin{array}{l}\text { Então a gente esqueceu de colocar uma coisinha... apaga o dois } \\
\text { também... ((aluna manuseia o mouse)) }\end{array}$ \\
\hline & 13 & AV & Deixa... deixa eu segurar? ((deleta o número 2 do texto)) \\
\hline \multirow[t]{2}{*}{$9^{\prime} 40^{\prime \prime}$} & 14 & $A B$ & $\begin{array}{l}\text { Não ((aluna manuseia o mouse e coloca o cursor no canto esquerdo da } \\
\text { página)) Tá... ó cê escreve aí pri:::que tem que tirar Jo-ken-po: ... coloca } \\
\text { primeiro o um né }\end{array}$ \\
\hline & 15 & AV & $\begin{array}{l}\text { U:m ((insere o número } 1 \text { no texto)) cadê aquele trequinho ((refere-se } \\
\text { ao hífen)) }\end{array}$ \\
\hline
\end{tabular}

Figura $14-\mathrm{AB} / \mathrm{AV}$ : Texto inicial

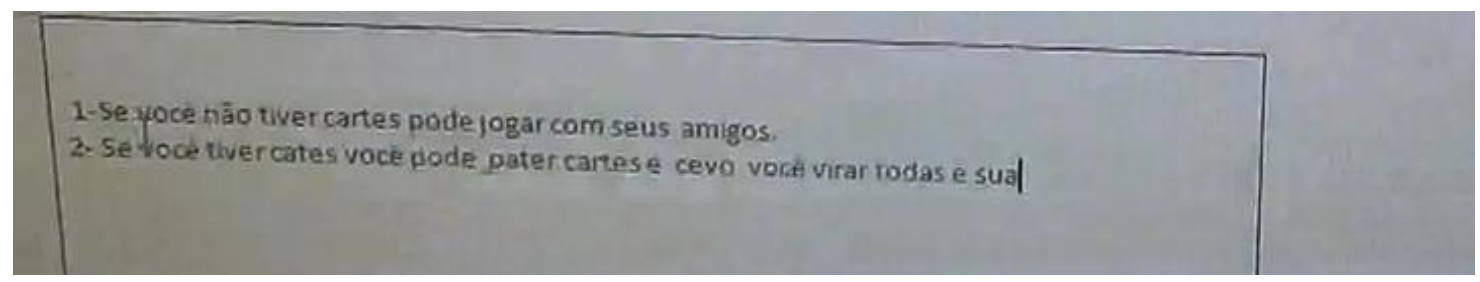

1- Se você não tiver cartes pode jogar com seus amigos.

2- Se você tiver cartes você pode pater cartes e cevo você virar todas é sua

O OT que emerge no comentário da dupla incide em um problema relacionado à organização das informações, ou seja, na planificação (DOLZ; GAGNON; DECÂNDIO, 2010). Ao realizarem a leitura do que já havia sido produzido na aula anterior, o aluno escriba (AV) propõe seguirem a lógica de organização e hierarquização dos conteúdos estabelecida na aula anterior e sugere "agora é três" (linha 05). No entanto, a aluna ditante ( $A B$ ) percebe que existem problemas na ordenação das ações e propõe que alterem a planificação textual inicialmente estabelecida. Sendo assim, AB solicita que o colega delete apenas a numeração, mantendo a redação (linhas 06, 08 e 10), e, concomitantemente, manuseia o mouse posicionando o cursor no canto superior esquerdo, com o intuito de inserir uma informação pertinente ao início do texto, reordenando a informação. Travaglia observa que alguns textos injuntivos atuam como planos - o caso das regras de jogo -, assim, a ordenação da sequência de ações e o modo como elas são apresentadas constituem um fator essencial ao funcionamento comunicativo do texto: 
"A ordem nestes tipos de textos que atendem um plano é quase uma ordem necessária. Dessa forma, inversões sempre causam problemas" (TRAVAGLIA, 1991, p. 181).

No que tange ao manuseio e usabilidade dos instrumentos, observamos poucos problemas. Ao início da tarefa, a professora estipulou que AV manusearia o teclado e AB ditaria o conteúdo. Assim, ao alterar a organização do texto, $A B$ manuseia o mouse com o intuito de posicionar o cursor no local exato, e, ao fazê-lo, AV manifesta a intenção de realizar a ação (linha 13). Ao final do trecho, AV busca onde se encontra o hífen no teclado (linha 15). O manejo das teclas Backspace, espaço e Enter, na lógica de funcionamento do editor de texto, foram executadas sem suscitar quaisquer dúvidas ou comentários.

A seguir, ao longo da redação da sentença "tem que tirar joquempo" (linha 17), os alunos realizam alguns comentários sobre segmentação, marcações de correção do editor de texto e questões ortográfica lexicais, como o uso do R no infinitivo, constituindo novos OTs.

Quadro 16 - Transcrição do OT ortográfico de AB/AV: segmentação

\begin{tabular}{|l|c|c|l|}
\hline Tempo & Linha & Interlocutor & Transcrição \\
\hline $10^{\prime} 00^{\prime \prime}$ & 17 & $\mathrm{AB}$ & TEM que tirar jokempo ((dita ao colega)) \\
\hline & 18 & $\mathrm{AV}$ & Te? \\
\hline & 19 & $\mathrm{AB}$ & TEM \\
\hline & 20 & $\mathrm{AV}$ & Tem ((digita ditando a palavra a si mesmo)) \\
\hline & 21 & $\mathrm{AB}$ & Que tirar jokempo \\
\hline & 22 & $\mathrm{AV}$ & Cadê o q? ((busca no teclado)) que::: \\
\hline & 23 & $\mathrm{AB}$ & Tirar \\
\hline & 24 & $\mathrm{AV}$ & $($ ) ((sussurro)) \\
\hline & 25 & $\mathrm{AB}$ & Tem que tiraR \\
\hline & 26 & $\mathrm{AV}$ & ((digita 'tira')) \\
\hline & 27 & $\mathrm{AB}$ & jokenpo \\
\hline & 28 & $\mathrm{AV}$ & ((digita 'tirajo')) \\
\hline & 29 & $\mathrm{AB}$ & É separado \\
\hline & 30 & $\mathrm{AV}$ & ((deleta a sílaba JO)) \\
\hline & 31 & $\mathrm{AB}$ & separa \\
\hline 10 '39'” & 32 & $\mathrm{AV}$ & ((insere o espaço depois da palavra 'tira')) \\
\hline & 33 & $\mathrm{AB}$ & Jokempo:: pra poder brin/ ó: é aqui ((aponta a supressão do colega: \\
& 34 & $\mathrm{AV}$ & Ah:: ((faz a correção apontada pela colega)) \\
\hline & 35 & $\mathrm{AB}$ & joquem \\
\hline & 36 & $\mathrm{AV}$ & Que:: ((fala a sílaba enquanto digita)) \\
\hline & 37 & $\mathrm{AB}$ & Po pra ver \\
\hline
\end{tabular}




\begin{tabular}{|c|c|c|l|}
\hline & 38 & AV & $\begin{array}{l}\text { ((aluno finaliza a escrita da palavra e surge um traço vermelho do editor } \\
\text { de texto - alunos observam a tela)) }\end{array}$ \\
\hline
\end{tabular}

Mantendo o papel de escriba, AV aglutina os vocábulos "tirar" e "joquempo". Imediatamente, a ditante $A B$ insta o colega a separar as palavras (linha 29), como se pode observar na Figura 15:

Figura 15 - AB/AV: Textualização - segmentação de palavras

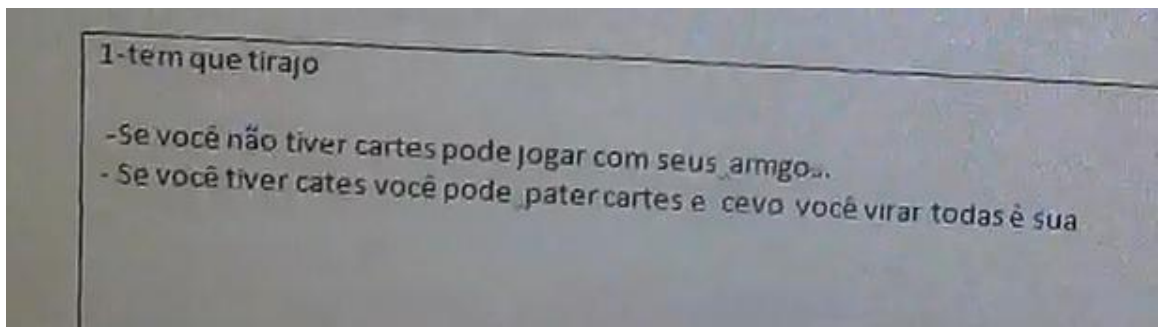

Ao finalizar a grafia da palavra "joquempo", $A B$ preocupa-se com a marcação apresentada pelo corretor automático do editor de texto. Esse movimento de revisão iniciado pelo corretor do programa gera um processo de revisão mais amplo que a ortografia da palavra que levou a marcação. Ao observarem a marcação do editor de texto (Figura 16), os alunos optam por deletar a palavra que levou o grifo, no caso, a "joquempo":

Quadro 17 - Transcrição do objeto textual técnico-gráfico de AB/AV: corretor automático do editor

\begin{tabular}{|c|c|c|l|}
\hline Tempo & Linha & Interlocutor & Transcrição \\
\hline & 36 & $\mathrm{AV}$ & Que:: ((fala a sílaba enquanto digita)) \\
\hline $11^{\prime} 00^{\prime \prime}$ & 37 & $\mathrm{AB}$ & Po::: pra ve:::r \\
\hline & 38 & $\mathrm{AV}$ & $\begin{array}{l}\text { ((aluno finaliza a escrita da palavra e surge um traço vermelho do } \\
\text { editor de texto - alunos observam a tela)) }\end{array}$ \\
\hline & 39 & $\mathrm{AB}$ & Tá errado \\
\hline & 40 & $\mathrm{AV}$ & $($ ) \\
\hline & 41 & $\mathrm{AB}$ & Então apaga... você escreveu errado \\
\hline & 42 & $\mathrm{AV}$ & ((deleta a palavra joquempo)) \\
\hline
\end{tabular}


Figura 16-AB/AV: Alunos observam o surgimento do traço vermelho do editor de texto, indicando problemas de ortografia

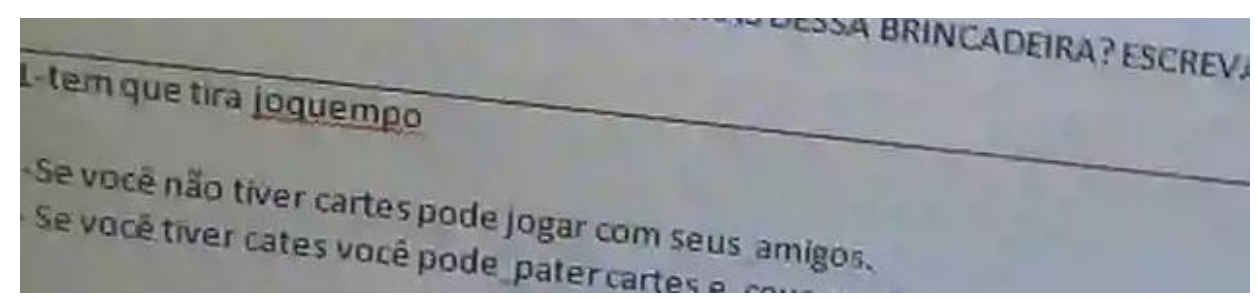

Após deletarem a palavra "joquempo", a aluna ditante $(A B)$ retoma a sentença e reordena a estrutura sintática da frase, extrapolando o nível da palavra e gerando uma reformulação de nível gramatical, sugerindo que o problema estava na construção sintática de "tem que tirar joquempo", e cria a hipótese de que deveriam inserir a preposição "para" ou "pra", formando a sentença "para tirar joquempo". Entre as linhas 43 e 46, os alunos discutem sobre essa questão. Essa ampliação da correção gera outros problemas textuais aos alunos, como a repetição da palavra "tirar" e a aglutinação das palavras "pra tirar".

Quadro 18 - Transcrição do OT composicional de AB/AV: estrutura frasal

\begin{tabular}{|c|c|c|l|}
\hline Tempo & Linha & Interlocutor & Transcrição \\
\hline $11^{\prime} 10^{\prime \prime}$ & 43 & $\mathrm{AB}$ & Pra:: tira::r jo-kem-po::: ((continua ditando)) \\
\hline & 44 & $\mathrm{AV}$ & PA tirar jo-kem-po \\
\hline & 45 & $\mathrm{AB}$ & pA/prA TIRAR \\
\hline & 46 & $\mathrm{AV}$ & Ah tá eu escrevi pa \\
\hline & 47 & $\mathrm{AB}$ & PRA... \\
\hline & 48 & $\mathrm{AV}$ & Espaço.. pra::: ((digita)) \\
\hline & 49 & $\mathrm{AB}$ & tiraR \\
\hline & 50 & $\mathrm{AV}$ & raR \\
\hline & 51 & $\mathrm{AB}$ & Tirar::: Jo-kem/... então assim... Pra depois separado \\
\hline & 52 & $\mathrm{AV}$ & Ah::: \\
\hline
\end{tabular}

Figura 17 - AB/AV: Reflexão sobre segmentação e ortografia, em movimento de revisão gerado pelo corretor automático do editor de texto

1-tem que tira pratir

- Se você não tiver cartes pode jogar com seus amigos.

Se vocé tiver cates você pode pater cartes e cevo você virar todas é sua 
Novamente, $A B$ inicia a correção sinalizando a necessidade de segmentar o termo "pra tirar" (linha 51), no entanto, observa a repetição do verbo "tirar" e orienta o colega.

Quadro 19 - Transcrição do OT composicional de AB/AV: estrutura frasal (continuação)

\begin{tabular}{|c|c|c|c|}
\hline Tempo & Linha & Interlocutor & Transcrição \\
\hline \multirow[t]{10}{*}{$11^{\prime} 30^{\prime \prime}$} & 53 & $A B$ & Não ó... apaga esse "tirar" aqui \\
\hline & 54 & AV & ((deleta a palavra indicada)) \\
\hline & 55 & $A B$ & Agora cê já/ pra:::: \\
\hline & 56 & AV & Pra:: \\
\hline & 55 & $A B$ & Pra tira:: jo-kem-po \\
\hline & 56 & AV & Pra:... ti:::rar ((fala pausadamente enquanto digita)) \\
\hline & 57 & $A B$ & {$[\mathrm{rar}$} \\
\hline & 58 & AV & Jo::quem::pó ((fala pausadamente enquanto digita)) \\
\hline & 59 & $A B$ & Eu acho que é separado Vinícius \\
\hline & 60 & AV & Deixa eu ver \\
\hline \multirow[t]{2}{*}{$12^{\prime} 03^{\prime \prime}$} & 61 & $A B$ & Não aqui ó tirar ((aponta as palavras "pratirar" na tela)) \\
\hline & 62 & AV & $(\ldots)$ \\
\hline \multirow[t]{8}{*}{$12^{\prime} 06^{\prime \prime}$} & 63 & $A B$ & Pra tirar...Pra::... tirAR... \\
\hline & 64 & AV & Rar:: ((fala enquanto digita)) \\
\hline & 65 & $A B$ & joquempo \\
\hline & 66 & AV & Jo ((fala enquanto digita)) \\
\hline & 67 & $A B$ & joquempo \\
\hline & 68 & AV & quem \\
\hline & 69 & $A B$ & Po... \\
\hline & 70 & AV & Pó.... deve ser assim.. po:::: ainda tá errado \\
\hline \multirow[t]{3}{*}{$12^{\prime} 30^{\prime \prime}$} & 71 & $A B$ & Deixa assim deixa assim... 'pra tirar joquempo'... aí cê coloca aqui dois \\
\hline & 72 & AV & Cê que manda hein ((insere o número dois na mesma linha)) \\
\hline & 73 & $A B$ & Não aí não Vinícius \\
\hline
\end{tabular}

Como vimos, a interpretação dos alunos em relação ao marcador de correção ortográfica gerou outros dois novos problemas: a repetição da palavra "tirar", solucionado pela dupla na linha 53, e um novo problema de segmentação (Figura 18), apontado por AB (linha 61). Ao realizarem os comentários sobre a necessidade de segmentar os vocábulos, repetem a palavra "tirar", salientando a pronúncia do R ao final dela e acabam por fazer, além da segmentação, a correção ortográfica das linhas 56 até a 64 (Figura 19). 
Figura $18-\mathrm{AB} / \mathrm{AV}$ : Apagamento de termo duplicado

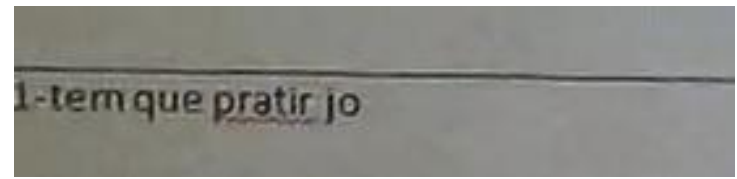

Figura 19 - AB/AV: Correção ortográfica

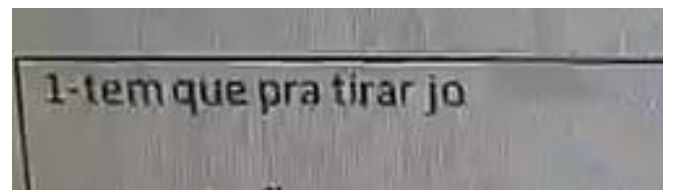

Apesar de todas as correções efetuadas pelos alunos ao terminarem de grafar a palavra “joquempo", a marcação do editor de texto permaneceu. Os alunos não conseguiram observar que se tratava de uma questão circunscrita à palavra Jo-Ken-Po e realizaram tentativas diversas para solucionar o problema, por meio de reordenações da estrutura gramatical da sentença. Após as tentativas frustradas, resolvem seguir adiante com a produção textual (linhas 70, 71).

A seguir, reorganizam a numeração conforme a previsão de ações a serem realizadas e seguem com a redação do item número 4.

Quadro 20 - Transcrição do OT ortográfico de AB/AV: escrita de palavra desconhecida

\begin{tabular}{|c|c|c|c|}
\hline Tempo & Linha & Interlocutor & Transcrição \\
\hline & 74 & AV & Bafão (( deleta o número dois)) \\
\hline \multirow[t]{2}{*}{$13^{\prime} 01^{\prime \prime}$} & 75 & $A B$ & $\begin{array}{l}\text { Aí é o três ((aponta o cursor na tela)) Pronto aí ce coloca quatro... dá } \\
\text { pra tirar bafã::o e mãozinha ((dita para o colega)) }\end{array}$ \\
\hline & 80 & AV & Ah escreve aí eu não sei brincar disso nunca brinquei na minha vida \\
\hline \multirow[t]{6}{*}{$13^{\prime} 40^{\prime \prime}$} & 81 & $A B$ & ((risos enquanto digita)) \\
\hline & 82 & AV & Bru ( ) escrevendo \\
\hline & 83 & $A B$ & "pra poder ti/brincs... dá pra jogar brincs" ((Lê em voz alta)) \\
\hline & 86 & AV & Brin... Brin... ((tom de brincadeira)) \\
\hline & 87 & $A B$ & É com M? \\
\hline & 88 & $\mathrm{AV}$ & Brim... B, R, I ((soletra))... B, R, I brim.... BRIM ... dar::: ((debocha)) \\
\hline \multirow[t]{2}{*}{$14^{\prime} 15^{\prime \prime}$} & 89 & $A B$ & [ ques \\
\hline & 90 & AV & vou brinda::::r ((debocha)) \\
\hline
\end{tabular}




\begin{tabular}{|c|c|c|c|}
\hline & 91 & $A B$ & Brinquis... Q, U, I ((soletra)) \\
\hline & 92 & AV & Queijo... ( ) quei::.. que \\
\hline \multirow[t]{5}{*}{$14^{\prime} 36^{\prime \prime}$} & 93 & $A B$ & pra \\
\hline & 94 & AV & [ brin \\
\hline & 95 & $A B$ & brinquis \\
\hline & 96 & AV & Brinque... Brin:::ques \\
\hline & 97 & $A B$ & brinques o S \\
\hline \multirow[t]{2}{*}{$14^{\prime} 45^{\prime \prime}$} & 98 & AV & Bri:::nquiS \\
\hline & 99 & $A B$ & Pra/ é com Q e não com K \\
\hline \multirow[t]{6}{*}{$14^{\prime} 58^{\prime \prime}$} & 100 & AV & Eu puis o QUI... ((deleta a última palavra escrita)) \\
\hline & 101 & $A B$ & Óh... pra poder tirar a Brin...quis \\
\hline & 102 & AV & ((digita novamente a palavra)) \\
\hline & 103 & $A B$ & Só o I qui tira esse /C/ daí... brinquis... coloca cinco ali embaixo \\
\hline & 104 & $\mathrm{AV}$ & $(1)$ \\
\hline & 105 & $A B$ & CINCO \\
\hline
\end{tabular}

No planejamento oral, $A B$ formula o seguinte conteúdo: "pra poder ti/brinques dá pra jogar brinques", que na versão escrita ganha a forma "da pra jogar a primbrinques". Observamos como a grafia de uma palavra que nunca foi realizada na língua escrita desloca a atenção dos alunos quase que exclusivamente a ela, fazendo-os recorrer à rota fonológica para a escrita, pronunciando repetidas vezes as sílabas e soletrando-as de modo a refletir sobre a relação fonografêmica (Figura 20).

Figura $20-A B / A V$ : Escrita de palavra desconhecida

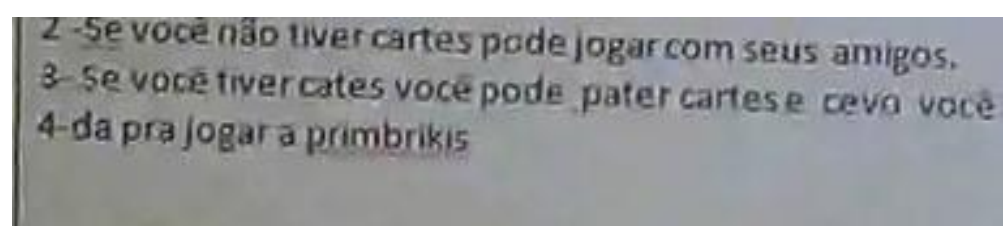

Assim, observamos que no processo de textualização, ao se depararem com uma palavra de ortografia completamente desconhecida, como o termo "brinques", específico do jogo, os alunos debatem acerca de questões ortográficas como: o uso de $\mathrm{M}$ ou $\mathrm{N}$, a estrutura da sílaba não canônica composta por CCV ao início da palavra e a grafia do fonema /k/ e o /s/ no final da sílaba. Ao lado dessas questões ortográficas, observamos que o acréscimo da sílaba "prim" formando a palavra "primbrikis" pode ter ocorrido por um equívoco associado à palavra "pra", utilizada no início da mesma sentença. 
A seguir, surge mais um OT relacionado à questão da planificação das informações presentes no texto seguido de outro OT relacionado à ortografia, como no trecho transcrito abaixo:

Quadro 21 - Transcrição do OT composicional e ortográfico de AB/AV: inserção de novas informações e escrita de sílaba não canônica

\begin{tabular}{|c|c|c|l|}
\hline Tempo & Linha & Interlocutor & Transcrição \\
\hline & 105 & $\mathrm{AB}$ & CINCO ((insere o cursor na linha abaixo pelo manuseio do mouse)) \\
\hline $15^{\prime} 31^{\prime \prime}$ & 106 & $\mathrm{AV}$ & Eu já FIZ ( ) \\
\hline & 107 & $\mathrm{AB}$ & Cinco “quem ganhar... ((dita ao colega)) \\
\hline & 108 & $\mathrm{AV}$ & Quem ganhar ((fala o que está sendo digitado)) \\
& 109 & $\mathrm{AB}$ & [fica com todas"... ((dita ao colega)) mas a gente já \\
& 110 & $\mathrm{AV}$ & Quem ganha o Jo-ken-po bate primeiro \\
\hline & 111 & $\mathrm{AB}$ & Ah::: então coloca... Que:::m ganha::: \\
\hline $16^{\prime} 00^{\prime \prime}$ & 112 & $\mathrm{AV}$ & ((digita /GA/)) \\
\hline & 113 & $\mathrm{AB}$ & GanhA é N ... H... A \\
\hline & 114 & $\mathrm{AV}$ & Agá a::: ((sussurro)) \\
\hline $16^{\prime} 13^{\prime \prime}$ & 115 & $\mathrm{AB}$ & Quem 154anha::: \\
\hline $16^{\prime} 14^{\prime \prime}$ & 116 & $\mathrm{AV}$ & [154anha vai te( ) \\
\hline & 117 & $\mathrm{AB}$ & [ o joquempo \\
\hline
\end{tabular}

Mantendo a estrutura numerada para organizar a cronologia das ações, AV propõe iniciar a sentença com "quem ganhar" (linha 108), no entanto, é interrompido por AB, que pensa que o colega vai propor uma informação já sugerida no item 3, "Se você tiver cates você pode pater cartes e cevo você virar todas é sua". O aluno AV explica que a informação é nova, pois se refere à outra ação executada no jogo (linha 110), e, assim recebe a aceitação da colega. O trecho analisado mostra mais uma vez como o não domínio automatizado da escrita de palavras compete a todo o momento com o desenvolvimento da competência metatextual. Ao final da aula, os alunos haviam realizado a seguinte produção textual: 
NOME: AV

NOME: $A B$

OS ALUNOS ADORAM BATER CARTAS NA HORA DO INTERVALO. QUAL O NOME DESSA BRINCADEIRA?

R:Cartes

VOCÊ CONSEGUE ESCREVER QUAIS AS REGRAS DESSA BRINCADEIRA? ESCREVA NO QUADRO ABAIXO:

1-tem que pra tirar joquenpo

2 -Se você não tiver cartes pode jogar com seus amigos.

3- Se você tiver cates você pode pater cartes e cevo você virar todas é sua

4-da pra jogar a brikis

5-quem ganha o joquempo bat iprimero

Esplição

1-quando você jogar a brikis

Analisando a produção realizada ao final da aula, podemos observar como trabalharam com a questão da organização das informações do texto por itens numerados em uma tentativa de facilitar a ordenação cronológica das ações a serem desempenhadas pelo leitor.

\subsubsection{Trabalho da dupla AT e AO}

A seguir, analisaremos o trabalho de AT, que atua como ditante, e AO, como escriba. As alunas acompanhadas nessa tarefa de revisão e continuidade da produção encontram, ao abrir seu arquivo, a seguinte construção textual:

Figura 21 -AT/AO: Produção escrita inicial

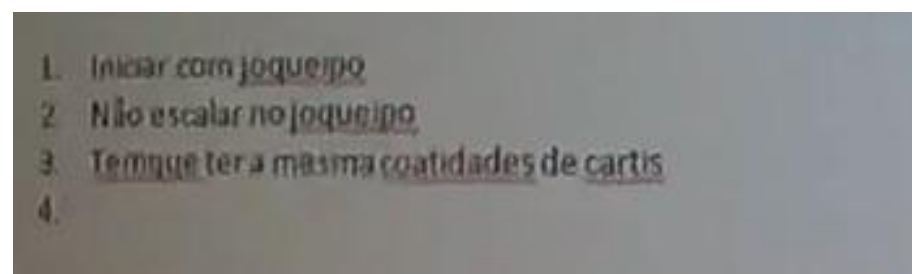

1. Iniciar com joqueipo

2. Não escalar no joqueipo

3. Temque ter a mesma coatidades de cartis

4. 
Por meio da análise da produção inicial, observamos que as alunas optaram por listar as ações a serem desempenhadas pelos jogadores seguindo uma sequência cronológica reforçada pela inserção de marcadores numerados organizando a lista. As alunas não se atêm aos problemas ortográficos indicados pela correção automática do editor de texto. Assim, preocupam-se em continuar a produção, planejando oralmente o que deverá constar no item 4.

Quadro 22 - Transcrição do OT composicional de AT/AO: estrutura frasal

\begin{tabular}{|l|c|l|l|}
\hline Tempo & Linha & Interlocutor & Transcrição \\
\hline $23^{\prime} 16^{\prime \prime}$ & 01 & AT & $\begin{array}{l}\text { Olívia vc faz assim ó vc pega e escreve 'se uma pessoa fala primeiro } \\
\text { uma coisa ((dita)) }\end{array}$ \\
\hline & 02 & AO & se::: u::ma:: ((digita pausadamente)) \\
\hline & 03 & AT & Pessoa::: fala... fala \\
\hline & 04 & AO & Uma coisa? \\
\hline & 05 & AT & A/uma/ alguma coisa \\
\hline & 06 & AO & Não... eu quero bater de mãozinha \\
\hline & 07 & AT & Ó \\
\hline $244^{\prime \prime} 0$ & 08 & AO & eu:: \\
\hline & 09 & AT & $\begin{array}{l}\text { NÃO ASSIM ASSIM ó 'se alguma pessoa fa/ alguma coisa a outra } \\
\text { pessoa tem que bater do jeito que a outra pessoa falou primeiro' }\end{array}$ \\
\hline & 10 & AO & Tá então... alguma... coisa:::: ((digita o texto)) essa pessoa né? \\
\hline & 11 & AT & essa pessoa tem que bater do jeito que a outra pessoa \\
\hline & AO & ((digita)) \\
\hline
\end{tabular}

A primeira proposta de AT na linha 01, "se uma pessoa fala primeiro uma coisa", é reformulada na linha 05, substituindo o artigo "uma" pelo pronome indefinido "alguma". AO sugere na linha 06 uma espécie de exemplificação (o que o jogador poderia falar), sugestão rechaçada pela ditante $A T$, que a reformula mais uma vez na linha 09 , utilizando duas vezes o pronome indefinido "alguma". A alteração entre o uso de um pronome indefinido no lugar do artigo indefinido não acarreta grandes alterações, tendo em vista que o pronome indefinido indica que algo ou alguém é considerado de forma indeterminada e imprecisa. De todo modo, os comentários realizados pelas alunas mostram uma certa reflexão sobre a estrutura gramatical da língua escrita, pois quando AO sugere algo mais próximo da língua falada, AT apresenta uma construção mais coerente com a gramática da língua escrita. Conforme aponta Soares acerca do processo de desenvolvimento da consciência gramatical, 
“[...] o processo é de identificação das violações, percebidas por meio do confronto com as estruturas gramaticais inconscientemente dominadas e usadas de forma espontânea na língua oral" (SOARES, 2016, p. 143).

Figura 22 -AT/AO: Textualização

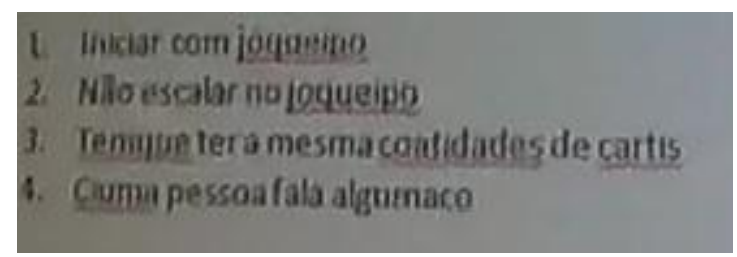

1. Iniciar com joqueipo

2. Não escalar no joqueipo

3. Temque ter a mesma coatidades de cartis

4. Ciuma pessoa fala algumaco

Por fim, AT finaliza a sentença, conforme observa mos no trecho abaixo:

Quadro 23 - Transcrição do OT composicional de AT/AO: estrutura frasal (continuação)

\begin{tabular}{|l|c|c|l|}
\hline Tempo & Linha & Interlocutor & Transcrição \\
\hline & 13 & AT & Va::i né... vai bater do jeito que ela falou \\
\hline & 14 & AO & Ba::ter... cadê... do jê::: ito que né \\
\hline & 15 & AT & Que ela falou \\
\hline & 16 & AO & Que:: e::la falou? ((digita)) \\
\hline & 17 & AT & é \\
\hline & 18 & AO & Pronto... agora na cinco ((aperta a tecla Enter)) \\
\hline $25^{\prime} 40^{\prime \prime}$ & 19 & AT & Na cinco eu não sei o que falar \\
\hline
\end{tabular}

No que tange às especificidades do ano escolar em questão, observamos pela análise da transcrição e da produção escrita um forte apoio na oralidade, especialmente pela manutenção da estrutura da língua oral, o que envolve, nesse caso, pouca reflexão sobre a estrutura própria da língua escrita. Já pela análise exclusiva do texto escrito, que não configuraram OTs por não terem sido alvo de comentário entre as alunas, observamos questões relacionadas a representações homofônicas, como "ciuma" em lugar de "se uma" e "coatidade" em lugar de "quantidade". Observamos também questões envolvendo hipossegmentação, tanto em casos em que as duas palavras aglutinadas apresentam conteúdo referencial próprio, como em 
"algumacoisa", quanto com palavras funcionais, de categorias vazias, como "aoutra" e "temque". Conforme observamos na Figura 23:

Figura 23 -AT/AO: Resultado da produção escrita

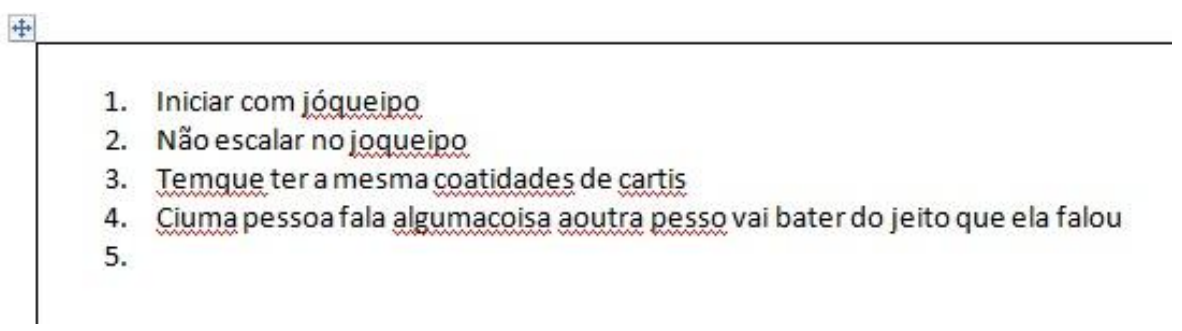

\subsubsection{Trabalho da dupla ALA e AR}

A dupla acompanhada apresenta níveis distintos de desenvolvimento da escrita. No trecho transcrito abaixo, não há uma divisão clara entre ditante e escriba. Observamos que AL, que apresenta um desempenho satisfatório na escrita, atua como uma espécie de leitora e revisora da produção, e AR, que apresenta dificuldades, inclusive na escrita de palavras, dita para si mesma enquanto digita. A tarefa consiste na continuação da produção escrita iniciada na aula anterior. As alunas estão explicando o significado do termo "raps", utilizado no jogo.

Quadro 24 - Transcrição do OT composicional, técnico-gráfico e ortográfico de ALA/AR: organização sintática, mudança de linha e segmentação

\begin{tabular}{|c|c|c|c|}
\hline Tempo & Linha & Interlocutor & Transcrição \\
\hline \multirow[t]{7}{*}{$24^{\prime} 20^{\prime \prime}$} & 01 & AR & $\begin{array}{l}\text { O raps é não pegar as cards dos outros ((fala e passa a mão na frente } \\
\text { da tela))... o/ raps/ é/ não/pegar as/as/as ca:: Ca:: cards ((dita } \\
\text { pausadamente enquanto escreve)) }\end{array}$ \\
\hline & 02 & ALA & ((digita)) \\
\hline & 03 & AR & $\begin{array}{l}\text { "O raps é não pegar as cards quando o outro... o outro " ((aluna lê o } \\
\text { que já foi escrito)) ti::::vê:::r tiver ((volta a ditar)) }\end{array}$ \\
\hline & 04 & ALA & Tiver né? \\
\hline & 05 & AR & Tiver fora... fora \\
\hline & 06 & ALA & Fora \\
\hline & 07 & AR & Tipo ((dita para si)) \\
\hline
\end{tabular}

CONTINUA \> 


\begin{tabular}{|c|c|c|c|}
\hline & 08 & ALA & Vai pra outra linha \\
\hline & 09 & AR & não \\
\hline & 10 & ALA & Tá errado \\
\hline & 11 & AR & Tipo... tipo o/ou/o/ou tro outro tipo o outro... ti:::ve:::r \\
\hline & 12 & ALA & Tiver \\
\hline & 13 & AR & $\begin{array}{l}\text { Como/como que vai lá pra baixo? ((aponta na tela o espaço da folha } \\
\text { que deseja posicionar o cursor)) }\end{array}$ \\
\hline & 14 & ALA & É só apertar aqui ó ((aponta o Enter)) \\
\hline & 15 & AR & Be:: bem/bebe::::ndo \\
\hline & 16 & ALA & Be:::be:::ndo \\
\hline & 17 & AR & U::ma \\
\hline & 18 & ALA & Bebendo bebendo \\
\hline & 19 & $A R$ & Bebendo uma a:::: a::: \\
\hline & 20 & ALA & Renata "bebendouma"? \\
\hline & 21 & AR & $\begin{array}{l}\text { PÁRA.... "á:::gua" ((fica irritada pelo fato da colega ter manuseado o } \\
\text { mouse)) }\end{array}$ \\
\hline & 22 & ALA & $\begin{array}{l}\text { "bebendo UMA água" ((posiciona o cursor entre as palavras } \\
\text { 'bebendo' 'uma' e insere o espaço)) }\end{array}$ \\
\hline $28^{\prime} 46^{\prime \prime}$ & 23 & AR & Ou almoçando/ almoça::ndo ((fala ditando)) \\
\hline
\end{tabular}

Da linha 01 até a linha 07, o processo de textualização ocorre sem maiores dúvidas. Até esse momento, conseguiram digitar "Orapis énãopegar as cardi cuando o ou tro tiver fora". Ao término desse trecho, ALA sinaliza a necessidade de mudar de linha, o que gera uma espécie de obstrução do fluxo de composição que vinha sendo empreendido por $A R$, que rechaça o comentário da colega e, bastante apegada à estrutura da língua falada, continua a produção do texto utilizando o termo "tipo", usual em registros orais informais, para iniciar uma exemplificação e acaba repetindo as mesmas palavras utilizadas anteriormente, "ou tro tiver", outra característica da fala. Nenhuma das duas cogitou o uso de pontuação, que configuraria uma boa alternativa para organizar o texto. Observamos a seguinte construção sintática:

Figura 24 -AR/ALA: Textualização e problemas de organização sintático/gramatical

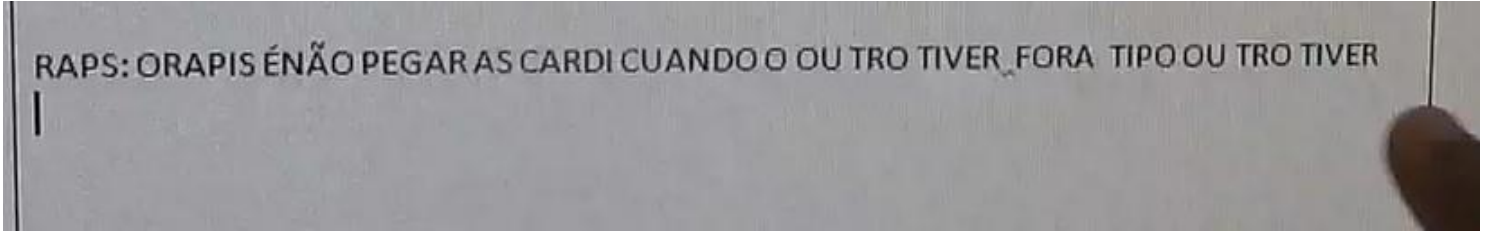


É possível que AR tenha decidido permanecer na mesma linha operando na mesma lógica do uso do caderno. No caso, ela não delimita as unidades de sentido e só muda de linha em virtude do término do espaço disponível na tela. Assim, observa-se também que AR desconhece a propriedade do editor de passar de uma linha para outra automaticamente. Essa hipótese é confirmada pelo comentário feito na linha 14, quando mesmo chegando ao final da linha, pergunta para ALA qual é o procedimento para "ir lá para baixo", indicando com o dedo onde gostaria de posicionar o cursor. Por fim, a colega aponta a tecla Enter, e assim ela pode continuar a produção.

Figura 25 - AR/ALA: Textualização e problemas de organização sintática

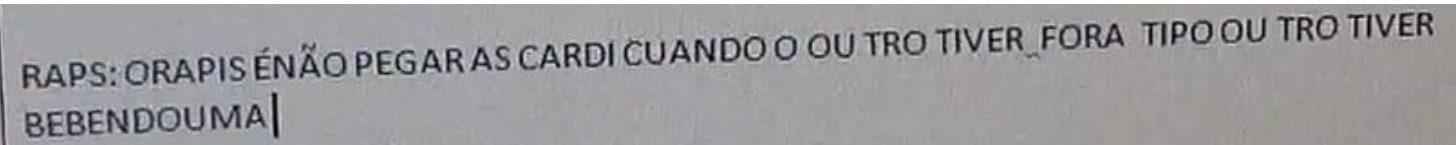

O segundo OT configura-se nos breves comentários das alunas sobre a aglutinação das palavras "bebendouma". AR soletra e digita "bebendouma", AL continua executando o movimento de revisão e, assim que realiza a leitura (linha 20), posiciona o cursor do mouse entre as duas palavras. No início, AR não compreende e pede que a colega pare de mover o cursor (linha 21). Na linha seguinte, ALA lê o trecho dando ênfase ao artigo "uma", de modo a chamar a atenção da colega para que "uma" constitui uma palavra, logo, precisa ser grafada separada da anterior e da posterior.

Figura 26 - AR/ALA: Resultado na produção na atividade 2

As figurinha tem nuuitas regras a regra 1 é. não fazer raps e não chorar potque perdeu A regra 2 é não roulsane não fazer grutes e pão pegar a figurinha semo outro ver A Regra 3 é não

RAPS: ORAPISÉNÃO PEGAR AS CARDI CUANDO O OU TRO TIVER FORA TIPOOU TRO TIVER BEBENDO UMA AGUA OU AMOÇANDOE| 


\subsection{Do coletivo para o individual (atividade 6)}

A aula é iniciada com a revisão coletiva de texto produzido por aluno. Se na atividade 2 o foco da revisão foi voltado para questões de coesão e coerência, nesta aula - atividade 6 - o foco da revisão incidiu em dois aspectos: o primeiro gira em torno de questões ortográficas, conferindo especial atenção às marcações do editor de texto; o segundo, a questões voltadas à diagramação final que o texto assumiria, assim, na revisão coletiva, a professora marca em qual parte do texto serão inseridas as figuras. A ideia de "marcar" consiste em inserir uma forma geométrica (retângulo) prevendo tanto uma diagramação adequada quanto sua adequação na composição textual, de modo que o texto escrito e a figura se complementem, enriquecendo a construção de sentidos do texto. Ao longo da revisão coletiva, a professora ensinou como inserir figuras geométricas e promoveu a reflexão sobre a função das ilustrações/figuras em textos instrucionais/injuntivos. Coletivamente, decidiram quais fotos seriam mais importantes para a compreensão do texto e, com o auxílio da professora e de um aparelho celular, tiraram três fotos. As fotos foram armazenadas na "pasta compartilhada", a mesma na qual os textos das duplas são armazenados ao longo do processo de produção escrita. Todo esse processo estava relacionado ao que aconteceria na aula subsequente (atividade 7), que seria destinada ao ensino dessa habilidade técnica: inserir figuras em texto utilizando ferramentas do editor.

\subsubsection{Trabalho da dupla ALF e AK}

A partir da consigna descrita acima, na dupla de alunos ALF e AK, ALF, aluno com maior destreza em relação à língua escrita, atuou como ditante, e AK, que ain da apresenta problemas na escrita de palavras, atuou como escriba. Eles acessam o documento para realizar a 2a revisão do texto produzido pela dupla anteriormente. Nessa interação, emergem dois OTs: o primeiro é de natureza ortográfica, trata-se de um problema de segmentação; e o segundo é de natureza técnica, envolvendo o manejo do mouse para o correto posicionamento do cursor na revisão do texto. 
Quadro 25 - Transcrição do OT ortográfico e técnico-gráfico de ALF/AK: segmentação e manejo do mouse - posicionamento do cursor

\begin{tabular}{|c|c|c|l|}
\hline Tempo & Linha & Interlocutor & Transcrição \\
\hline 18'33'” & 10 & ALF & $\begin{array}{l}\text { A ganhas aqui tá errado... tem que escrever o /a/ separado e o } \\
\text { ganhas... corrige aí Keylla ((aluno aponta a tela e a marcação do } \\
\text { corretor do editor de texto)) }\end{array}$ \\
\hline & 11 & AK & Foi você que fez tá \\
\hline & 12 & ALF & Tá vamos ver se dá certo \\
\hline & 13 & AK & Cadê ((aluna busca na tela a qual problema o colega se refere)) \\
\hline & 14 & ALF & Bem no meio do /g/ e do /a/ aqui ó ((aponta a tela)) \\
\hline $18^{\prime} 56^{\prime \prime}$ & 16 & AK & Gente é difícil fazer isso ((coloca o cursor ente o artigo e a palavra)) \\
\hline
\end{tabular}

No trecho acima, os alunos estão engajados no processo de revisão do texto produzido em aulas anteriores e são orientados na consigna da atividade a observar as marcações do corretor automático do editor de texto. O primeiro OT que emerge nesse trecho indica uma questão ortográfica (segmentação). Para resolver essa questão, emerge outro OT de ordem técnica, pois para inserir o espaço entre as palavras é necessário posicionar o cursor no local específico e, para tal, é necessário o manejo do mouse.

Observando o texto produzido nas aulas anteriores, ALF observa que o nome de uma modalidade do jogo denominada "ganhas" estava grafado de forma aglutinada ao artigo A (linhas 10 e 12). O aluno indica onde AK deve inserir o espaço para separar o substantivo do artigo (linha 14). Em seguida, durante a execução do manejo do mouse, AK expressa dificuldade em posicionar o cursor no local correto (linha 15). Realizada a alteração, AL comemora que o marcador da revisão desapareceu, indicando que o problema ortográfico havia sido sanado (Figuras 27 e 28).

Figura 27 -ALF/AK: Segmentação e posicionamento do cursor

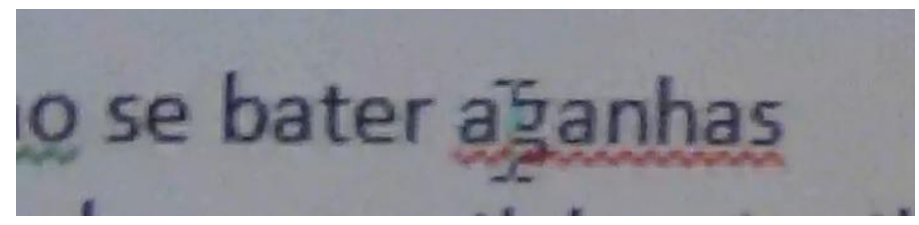


Figura 28 -ALF/AK: Resolução do problema de segmentação

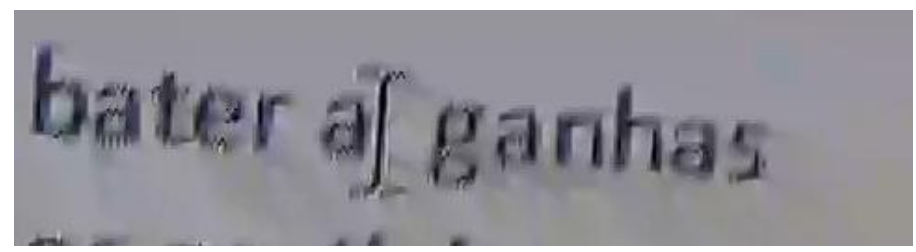

Obtendo sucesso na estratégia de correção e manuseio do mouse, os alunos buscam no texto outras ocorrências. ALF sugere que o nome de outra modalidade do jogo poderia ter sido escrito de modo aglutinado, e seguem com a busca (linhas 22, 23 e 24).

Quadro 26 - Transcrição do OT ortográfico e técnico-gráfico de ALF/AK: segmentação e manejo do mouse - posicionamento do cursor (continuação)

\begin{tabular}{|l|c|c|l|}
\hline Tempo & Linha & Interlocutor & Transcrição \\
\hline $19^{\prime} 30^{\prime \prime}$ & 22 & ALF & $\begin{array}{l}\text { Agora vamos ver mais outro... vamos tentar a brinques separado } \\
\text { também igual }\end{array}$ \\
\hline & 23 & AK & Pera::: .... vai pode ir Luiz \\
\hline & 24 & ALF & Agora vamos ver aqui ó ((o aluno coloca a mão na tela)) \\
\hline & 25 & AK & PERA deixa eu ver se tem mais algu:::m... a brinques ó \\
\hline $19^{\prime} 45^{\prime \prime}$ & 26 & ALF & $\begin{array}{l}\text { Agora vê essa brinques ó ((aponta o problema de segmentação na } \\
\text { tela)) }\end{array}$ \\
\hline & 27 & AK & Agora tem que colocar o /r/ ((risos)) \\
\hline & 28 & ALF & Agora volta coloca bem aqui no meio do:::: \\
\hline & 29 & AK & Cadê o negócio? ((se refere ao cursor do mouse)) \\
\hline $20^{\prime} 16^{\prime \prime}$ & 30 & ALF & Aqui ó ((aponta na tela)) \\
\hline & 32 & AK & Tira do dedo daí \\
\hline & 33 & AK & Isso \\
\hline & 34 & ALF & (( insere o espaço entre as palavras)) \\
\hline $20^{\prime} 57^{\prime \prime}$ & 36 & AK & Não pera ((aluna retoma a leitura)) \\
\hline
\end{tabular}

Ao encontrar uma ocorrência de palavras aglutinadas, ALF aponta na tela onde a colega deve posicionar o cursor. Ao fazê-lo, AK acaba selecionando a letra, conforme podemos observar na Figura 29. 
Figura 29 - ALF/AK: Problema de segmentação e seleção de letra em lugar de posicionamento do cursor

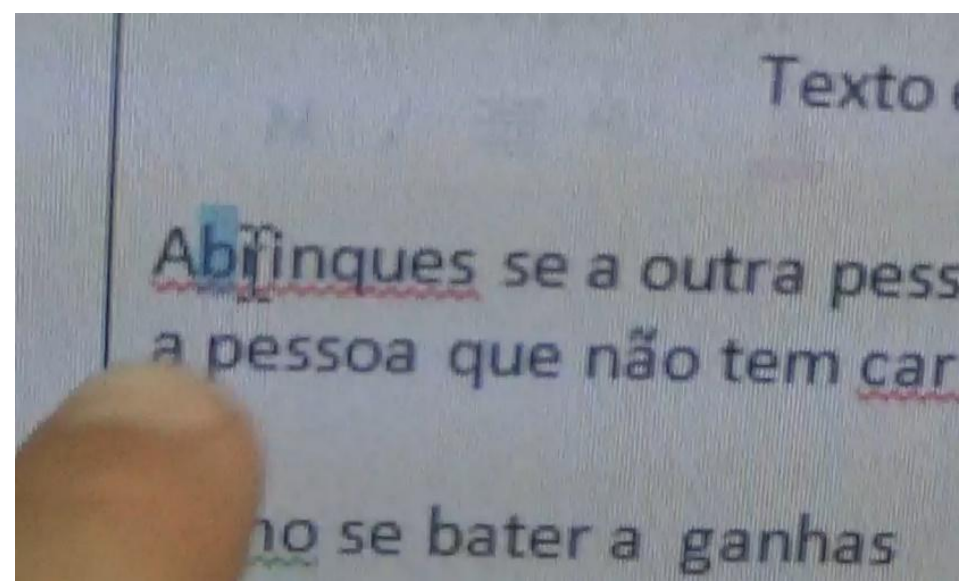

Por AK ter selecionado a letra ao invés de simplesmente posicionar o cursor, os alunos se deparam com um problema: selecionar a letra e apertar a tecla espaço implica no apagamento da letra. Desse modo, os alunos precisam repetir o procedimento de posicionar o cursor e executar tanto o espacejamento quanto a inserção da letra que foi deletada por engano (linhas 27 a 33). Após realizarem os ajustes, ALF comemora porque o marcador do editor de texto foi eliminado.

Esse trecho apresenta de maneira bastante clara como a resolução de um problema ortográfico lexical - a segmentação - depende do domínio de uma habilidade técnica, no caso, o manejo do mouse e o posicionamento adequado do cursor.

\subsubsection{Trabalho da dupla AGO e AW}

Abaixo, o momento em que os alunos $A G O$ e AW retomam o texto que produziram há uma semana. Na composição da dupla, AGO, que apresenta melhor desempenho na escrita, atua como ditante, e AW, com maiores dificuldades, atua como escriba. Apesar da delimitação de papéis, há momentos em que alternam o uso do teclado. Após a realização da consigna pela professora, os alunos acessam o texto que produziram nas aulas anteriores, leem o que já escreveram e, apesar da consigna sugerir que revisem o que já escreveram, não realizam quaisquer modificações. Assim que o texto é acessado, os alunos dão continuidade à sua produção escrita, conforme é possível observar no trecho abaixo: 
Quadro 27 - Transcrição do OT ortográfico AGO/AW: homofonia

\begin{tabular}{|c|c|c|l|}
\hline Tempo & Linha & Interlocutor & Transcrição \\
\hline $12^{\prime} 57^{\prime \prime}$ & 01 & AGO & ((aluno digita a palavra 'matancia' e em seguida deleta)) \\
\hline & 02 & AW & \begin{tabular}{l} 
[ Você mudou tudo \\
\hline
\end{tabular} \\
\hline & 03 & AGO & Tá errado de novo ((aluno faz mais uma tentativa usando a letra S)) \\
\hline $13^{\prime} 40^{\prime \prime}$ & 05 & AW & $\begin{array}{l}\text { Ta.. ta... tan... tá mantanSIA... tá matan/ Tá matansia... Eu vou } \\
\text { perguntar pra pro... professo::.:ra }\end{array}$ \\
\hline $13^{\prime} 58^{\prime \prime}$ & 06 & AGO & $\begin{array}{l}\text { [ não não não não ((aluno deleta a } \\
\text { palavra)) tan... ((sussurra)) tan... tança matança ((digita com Ç e } \\
\text { observa que não há mais marca de revisão)) }\end{array}$ \\
\hline
\end{tabular}

A escrita da palavra "matancia" em lugar de "matança" (Figura 30) gera um OT no interior do processo de textualização. O modo como os alunos lidam com a escrita dessa palavra, um termo específico do jogo e, consequentemente, pouco frequente nos textos aos quais as crianças têm acesso, mostra como, sendo eles escritores pouco experientes, nas duas primeiras tentativas, não obtiveram sucesso. A primeira tentativa de escrita e revisão das palavras "matancia" e "matansia" (Figuras 30 e 31) pode ter acontecido por analogia à forma sufixal -ancia em lugar do sufixo -ança, que, conforme Bechara (2004), ao lado das formas -ença e -encia são sufixos formadores de substantivos, nos quais, em alguns casos, as duas formas se alternam, como em "convalescença" e "convalescência". É interessante observarmos que nas duas primeiras tentativas não houve silabação, soletração ou qualquer repetição de sons em voz alta. É provável que AGO tenha utilizado a rota lexical/visual para realizar a primeira tentativa de escrita (Figura 30). Ao surgir a marcação vermelha do corretor, AGO busca as regras ortográficas que já conhece e substitui a letra Ç por $\mathrm{S}$, demonstrando que já reconhece que os grafemas $\langle c ̧>,\langle s\rangle$ e $\langle$ ss $>$ competem para representar o fonema /s/. No entanto, não reconhece a questão contextual implicada, pois caso já tivesse domínio da regra, a questão ortográfica giraria em torno dos grafemas <ss $>$ e <ç>. É possível observarmos o movimento de reflexão metalinguística para a resolução do problema ortográfico. Caso os alunos já tivessem mais familiaridade com a escrita, poderiam ter associado a palavra a outras com o sufixo -ança, que atribui sentido de ação ou resultado dela, relacionando o verbo "matar" com o acréscimo do sufixo, como no caso de "vingança", "lembrança", entre outras. 
Apenas a partir do comentário realizado pela colega AW, no qual pronuncia a palavra escrita de maneira silabada, salientando o valor sonoro da sílaba SI (linha 04), que AGO deleta o que havia escrito e recorre à rota fonológica para a escrita da palavra, repetindo as sílabas em voz alta (linha 05).

É importante observarmos que todo esse movimento de retorno à palavra buscando sua correção ortográfica foi motivada pela marcação do corretor automático do editor de texto. É provável que caso não houvesse a marcação, os alunos iriam seguir a textualização sem se engajar no processo de revisão ortográfica da palavra.

Figura 30 -AG/AW: Problema ortográfico em palavra termo do jogo (1a tentativa)

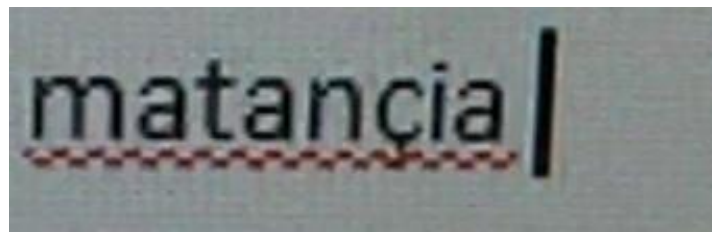

Figura 31 - AG/AW: Problema ortográfico em palavra termo do jogo (2 2 tentativa)

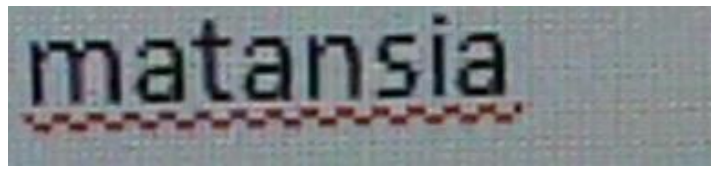

Figura $32-A G / A W$ : Escrita de palavra termo do jogo (3a tentativa)

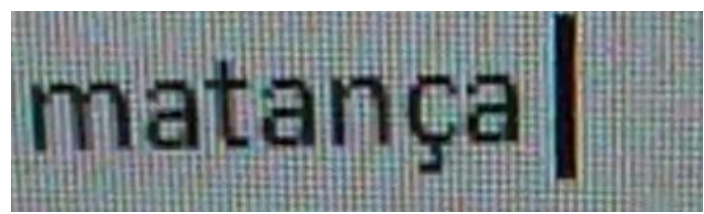

Após alguns minutos, a dupla AGO/AW cessa a produção e relê o que já escreveu até o momento. $\mathrm{O}$ trecho transcrito abaixo aborda três diferentes OTs que ocorrem relacionados um ao outro. O primeiro é de natureza composicional, o segundo é de natureza ortográfica e o terceiro incide em uma questão técnica relacionada ao uso do teclado. 
Quadro 28 - Transcrição do OT composicional, ortográfico e técnico-gráfico de AGO/AW

\begin{tabular}{|c|c|c|c|}
\hline Tempo & Linha & Interlocutor & Transcrição \\
\hline & 20 & AG & $\begin{array}{l}\text { "Todos cardes viradas para trás... matança duas ou mais cardes } \\
\text { matança só pode... só pode" ((lê em voz alta)) }\end{array}$ \\
\hline & 21 & AW & [ só pode \\
\hline \multirow[t]{9}{*}{$17^{\prime} 43^{\prime \prime}$} & 22 & AG & $\begin{array}{l}\text { Só pode ba:::/mãozinha ((começa a apagar o trecho "bate com } \\
\text { mãozinha")) }\end{array}$ \\
\hline & 23 & AW & Só pode com mãozinha \\
\hline & 24 & AG & Só pode (( deleta o final da frase)) \\
\hline & 25 & AW & $\begin{array}{l}\text { bateR com ((aluna lê enquanto o colega deleta o trecho)) tava certo } \\
\text { menino! }\end{array}$ \\
\hline & 26 & AG & $\begin{array}{l}\text { Não eu não coloquei o /R/ (( ao iniciar o apagamento da palavra } \\
\text { "bate" o aluno se dá conta de que esqueceu de inserir o R ao final da } \\
\text { palavra) }\end{array}$ \\
\hline & 27 & AW & Não precisa apagar... o::: meu pai \\
\hline & 28 & AG & $\begin{array}{l}\text { Cadê cadê cadê? ((escrevendo novamente "mãozinha" o aluno busca } \\
\text { o til no teclado)) }\end{array}$ \\
\hline & 29 & AW & Eu já puis \\
\hline & 30 & AG & Não foi dois AS... foi dois AS \\
\hline $18^{\prime} 25^{\prime \prime}$ & 31 & AW & Que que você fez... aqui ó ((risos)) \\
\hline \multirow[t]{9}{*}{$18^{\prime} 30^{\prime \prime}$} & 32 & AG & assim ó aperta o A não ((apaga as duas letras /a/ digitadas)) \\
\hline & 33 & AW & ((aluna digita o /a/)) \\
\hline & 34 & AG & Era pra você aperta só depois que eu fala \\
\hline & 35 & AW & Já ((aluna digita o /a/)) \\
\hline & 36 & AG & $\begin{array}{l}\text { Primeiro tem que aperta esse ... primeiro tem que aperta ((indica a } \\
\text { tecla com o til no teclado)) depois o } \mathrm{A}\end{array}$ \\
\hline & 37 & AW & ((aluna digita a letra /a/ e em seguida a letra /a com acento agudo)) \\
\hline & 38 & AG & Apaga o A... aperta o... \\
\hline & 39 & AW & Tá errado? ((aluna digita a letra A com acento agudo)) não se:::i \\
\hline & 40 & $A G$ & $\begin{array}{l}\text { É esse... ((aponta o a tecla til)) Primeiro é esse depois é /a/ ((apagam } \\
\text { a letra A com acento agudo)) }\end{array}$ \\
\hline $19^{\prime} 00^{\prime \prime}$ & 41 & AW & l:::sso... mãozinha \\
\hline
\end{tabular}

No interior do processo de revisão de textos, os alunos revezam a leitura em voz alta. AGO, ao fazer a leitura do trecho "matança só bate com mãozinha" (Figura 33), realiza uma reformulação oral e na leitura em voz alta pronuncia "matança só pode... só pode" (linhas 20 a 24). Provavelmente, a intenção do aluno era reformular a sentença acrescentando o verbo "pode", de modo que a redação após a correção final ficou com a seguinte estrutura: "matança só pode bate com mãozinha". Assim, AGO deleta o que havia escrito para reformular a sentença 
(Figura 34). Esse trecho configura, no interior do processo de revisão de texto, um OT relacionado à estrutura gramatical da sentença.

Figura 33-AGO/AW: Trecho lido e reformulado oralmente por AG

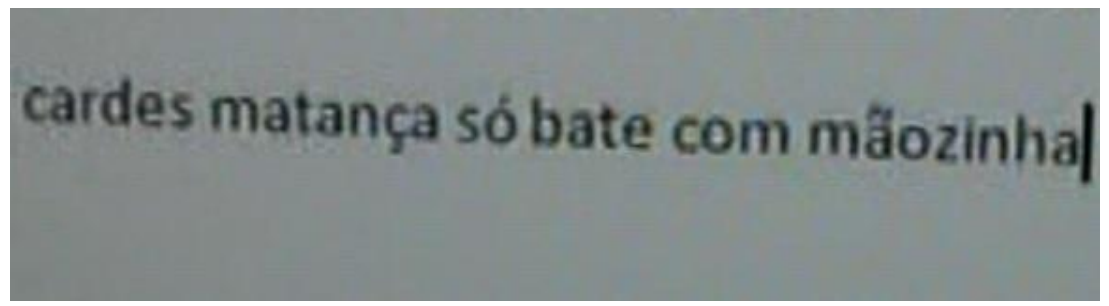

Figura 34 - AGO/AW: Sentença com seu final deletado para correção

\section{mais cardes matança só bate}

No entanto, após deletar parte da escrita, os alunos iniciam um novo OT em torno da forma na qual o verbo "bater" deveria ser inserido no trecho (linhas 25 e 26). Inicialmente, grafaram "bate", e no momento de revisão comentam que seria mais adequado utilizar o verbo no infinitivo, "bater" (Figura 35).

Figura 35 - AGO/AW: Acréscimo do R final de infinitivo

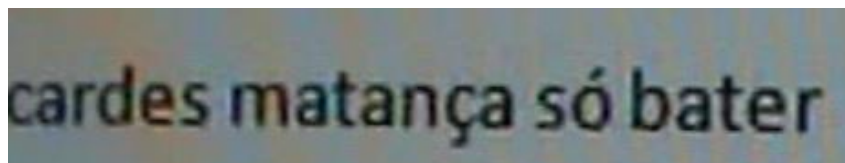

Feito o ajuste na grafia do verbo, reescrevem o trecho "com mãozinha", no entanto, surge um problema de usabilidade do teclado, envolvendo a grafia do diacrítico til (linha 28 a 40). O fato de precisarem articular mais de uma tecla para realizar a marcação do til causa alguns problemas. Na primeira tentativa (Figura 36), a vogal acaba sendo duplicada (linha 30). Depois, buscam coordenar como inserir o diacrítico: um aluno tecla a letra, e o outro, o sinal gráfico (linha 32 a 36), no entanto, acabam novamente duplicando a vogal e inserindo o acendo 
agudo (Figura 37). Em uma última tentativa, inserem apenas uma vogal, mas ainda com o acento agudo em lugar do diacrítico til (Figura 38). Por fim (linha 39 a 41), conseguem inserir o diacrítico desejado (Figura 39).

Figura 36 - AGO/AW: Tentativa de inserção do diacrítico til (duplicação da vogal)

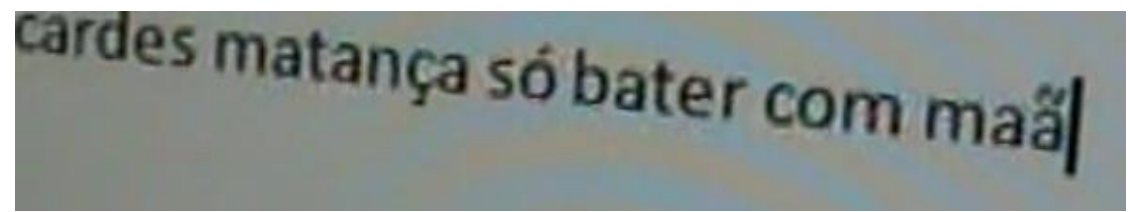

Figura 37 - AGO/AW: Tentativa de inserção do diacrítico til (duplicação da vogal e uso do acento agudo)

icardes matança só bater com maá|

Figura 38 -AG/AW: Tentativa de inserção do diacrítico til (acento agudo)

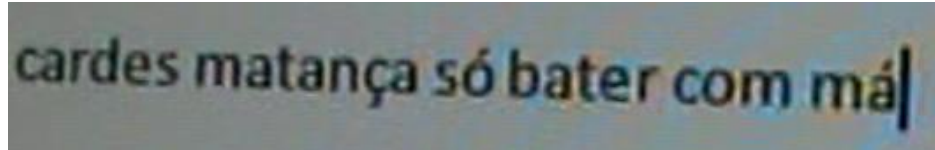

Figura 39 - AG/AW: Inserção do diacrítico til

\section{matança só bater com mãozinnha|}

Neste trecho em que encontramos três OTs - a reformulação sintática, a correção ortográfico-gramatical do verbo "bater" e o uso do diacrítico til -, interessa-nos especialmente pensar que todo o movimento de revisão se deu por conta do primeiro OT, ou seja, da reformulação sintática. No entanto, ao se depararem com uma questão ortográfica, os alunos deixam de lado o primeiro problema e se concentram em questões voltadas à ortografia. $\mathrm{O}$ que ocorreu nesse trecho reencontra o que Góes aponta sobre o processo de revisão realizado por crianças em fase de alfabetização: 
Essas observações indicam que a análise do texto se resumia a algumas das convenções de registro. Tal restrição a aspectos de superfície, quase que exclusivamente ortográficos, parece refletir a experiência das crianças com a prática de produção e avaliação de texto em sala de aula. Podemos dizer que, de um modo limitado, a revisão que faziam caracterizava um certo ajustamento ao leitor. Contudo, não envolvia a tomada de organização dos enunciados como objeto de análise e, consequentemente, não implicava uma abordagem deliberada da questão dialógica do ato de escrever. (GÓES, 1993, p. 104).

Ainda, podemos pontuar uma questão voltada à usabilidade do instrumento, pois caso os alunos não tivessem deletado parte da sentença, ou seja, se tivessem simplesmente posicionado o cursor em posição imediatamente anterior ao verbo "bater", provavelmente teriam se concentrado no problema inicial somente pela inserção do verbo "poder", conseguindo, assim, a estrutura formulada oralmente "pode bater".

A interação dos alunos com o texto e com essas questões nos remete a um problema típico da fase em que eles se encontram. Conforme aponta Soares (2016), por ainda estarem em processo de alfabetização, a presentam muitas dúvidas em relação à ortografia das palavras e, assim, acabam deixando de lado aspectos mais voltados à estrutura composicional. Em outras palavras, no processo de revisão, ao iniciar uma reflexão metassintática/metagramatical, ele acaba sendo abandonado, priorizando aspectos mais voltados aos subsistemas da língua escrita, como a ortografia, bem como ao manejo correto do instrumento de inscrição - no caso, o teclado.

\subsection{Inserindo imagens no texto (atividade 7)}

A tarefa consiste em finalizar a redação da regra de jogo e inserir as imagens que haviam combinado previamente. Nas aulas anteriores, os alunos realizaram momentos de produção e revisão coletiva de texto, nos quais, após refletirem sobre elementos de coesão e coerência, decidiram quais imagens contribuiriam mais para a sua compreensão. Assim, fotografaram dois movimentos do jogo e um tipo de posicionamento específico das cartas, pois acordaram que seria muito complicado explicá-los por meio da escrita. Essas imagens foram disponibilizadas 
pela professora em uma pasta do gerenciador de arquivos compartilhada via intranet, à qual todos tinham acesso por seus computadores.

No início da aula, a professora explicou, por meio de exemplificação via projeção da tela do servidor nas telas dos alunos, todo o procedimento técnico envolvido na inserção de figuras no editor de texto Word.

\subsubsection{Trabalho da dupla AE e AG}

No trabalho acompanhado abaixo, AE assume papel de escriba e AG deveria atuar como ditante. Os dois alunos apresentavam bom domínio do sistema alfabético de escrita à época da pesquisa. O trecho transcrito abaixo se refere aos comentários feitos acerca da inserção das figuras no texto.

Quadro 29 - Transcrição do OT técnico-gráfico AE/AG: paginação

\begin{tabular}{|c|c|c|c|}
\hline Tempo & Linha & Interlocutor & Transcrição \\
\hline \multirow[t]{6}{*}{$13^{\prime} 15^{\prime \prime}$} & 01 & $\mathrm{AE}$ & $\begin{array}{l}\text { Aí agora eu vou colocar a foto... tá bom né? ((busca a foto no } \\
\text { gerenciador de arquivos)) }\end{array}$ \\
\hline & 02 & AG & ((aceno positivo)) \\
\hline & 03 & $\mathrm{AE}$ & “Mãozinha" ((lê )) \\
\hline & 04 & AG & Ua:::u ((exclama ao ver a foto no texto)) \\
\hline & 05 & $\mathrm{AE}$ & Tá bom desse jeito? \\
\hline & 06 & AG & ((aceno positivo)) \\
\hline $14^{\prime} 30^{\prime \prime}$ & 07 & $\mathrm{AE}$ & Não... aqui não ((ajusta a segunda foto no texto)) \\
\hline \multirow[t]{2}{*}{$14^{\prime} 38^{\prime \prime}$} & 08 & $A E$ & $\begin{array}{l}\text { Cadê... ( ) melhor chamar a professora (( a página do editor aparece } \\
\text { apenas parcialmente na tela)) }\end{array}$ \\
\hline & 09 & AG & E agora? ((AE clica em "desfazer" )) Melhor assim \\
\hline $15^{\prime} 07^{\prime \prime}$ & 10 & $\mathrm{AE}$ & Cadê o texto? Ah chama a professora aí... professora \\
\hline \multirow[t]{5}{*}{$15^{\prime} 20^{\prime \prime}$} & 11 & $A E$ & $\begin{array}{l}\text { A profa falou assim que é pra fazer assim né ((desliza o dedo na tela)) } \\
\text { quando coisa }\end{array}$ \\
\hline & 12 & $\mathrm{PE}$ & $\mathrm{I}:::$ :Sso \\
\hline & 13 & $\mathrm{AE}$ & $\begin{array}{l}\text { Mas aí olha o que que aparece ((a aluna reduz o tamanho da imagem } \\
\text { e a página do editor de texto aparece cortada)) }\end{array}$ \\
\hline & 14 & $\mathrm{PE}$ & Aí você sobe lá \\
\hline & 15 & $\mathrm{AE}$ & É aqui? ((se refere a barra de rolagem)) \\
\hline $15^{\prime} 40^{\prime \prime}$ & 16 & PE & $\begin{array}{l}\text { É sobe um pouquinho é por que como a figura estava muito grande } \\
\text { ela estava na outra página }\end{array}$ \\
\hline
\end{tabular}




\begin{tabular}{|c|c|c|c|}
\hline & 17 & $\mathrm{AE}$ & A:::h tá \\
\hline & 18 & PE & $\begin{array}{l}\text { Agora o que que você tem que fazer... essa daqui ((aponta a figura na } \\
\text { tela)) clica com o mouse em cima e arrasta um pouquinho pra cá } \\
\text { ((aponta o espaço na tela)) }\end{array}$ \\
\hline & 19 & $\mathrm{AE}$ & ((aluna executa o movimento mas não funciona)) \\
\hline & 20 & PE & $\begin{array}{l}\text { Você sabe por que que ficou grudadinha? É por que vocês não deram } \\
\text { um espacinho... tira essa imagem Evellyn e insi/insere de novo }\end{array}$ \\
\hline & 21 & $\mathrm{AE}$ & ((aluna deleta a imagem)) \\
\hline & 22 & PE & $\begin{array}{l}\text { Aí ó:::h tá vendo clica aqui o cursor do mouse ((aponta na tela)) e dá } \\
\text { espaço ó::: tá vendo? Assim ela não vai ficar grudada ((professora sai)) }\end{array}$ \\
\hline & 23 & $\mathrm{AE}$ & Aqui tá bom né? \\
\hline \multirow[t]{2}{*}{$16^{\prime} 23^{\prime \prime}$} & 24 & AG & Uhun \\
\hline & 25 & $\mathrm{AE}$ & Oxi \\
\hline \multirow[t]{3}{*}{$18^{\prime} 29^{\prime \prime}$} & 26 & $\mathrm{AE}$ & Tomara que fique no lugar agora \\
\hline & 27 & $A G$ & Ohhhh \\
\hline & 28 & $\mathrm{AE}$ & Olha... que cabeça \\
\hline
\end{tabular}

Após finalizarem a parte escrita, AE propõe que iniciem o processo de inserção das imagens (linha 01). Rapidamente, a aluna localiza a aba Inserir na faixa de opções ${ }^{92}$ do editor de texto, clica no botão Imagens e opera a janela do gerenciador de arquivos aberta em virtude deste último comando, conforme observamos na figura abaixo:

Figura $40-A E / A G$ : Alunos buscando a foto no gerenciador de arquivos

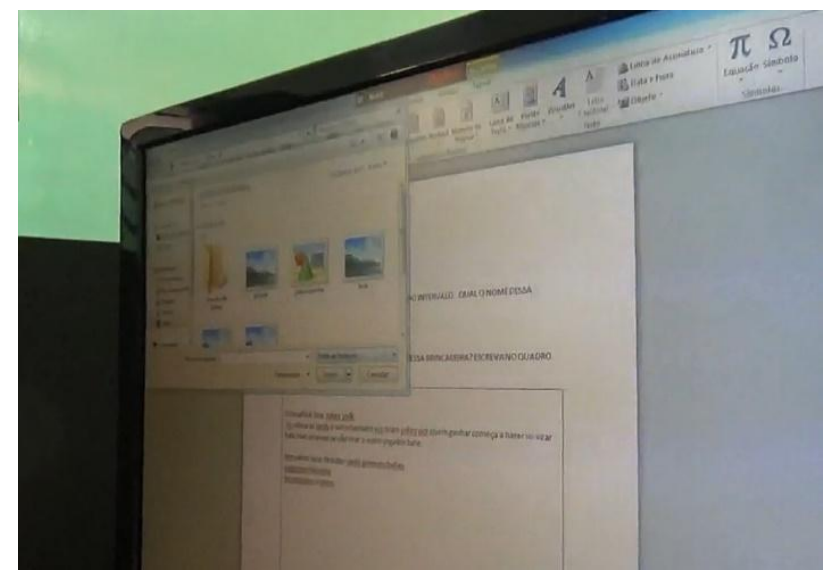

\footnotetext{
${ }^{92}$ Nome dado ao espaço superior da tela do editor de texto, onde estão os principais comandos do Word versão 2003, separados por oito guias: Início, Inserir, Layout da Página, Referências, Correspondências, Revisão, Exibição e Suplementos.
} 
A aluna navega ${ }^{93}$ sem apresentar dificuldades pelas janelas do interior do gerenciad or de arquivos até a pasta na qual estavam armazenadas as fotos e executa dois cliques rápidos, o que permite que a foto seja inserida no texto (Figura 41).

Figura 41-AE/AG: Foto em tamanho grande inserida no texto

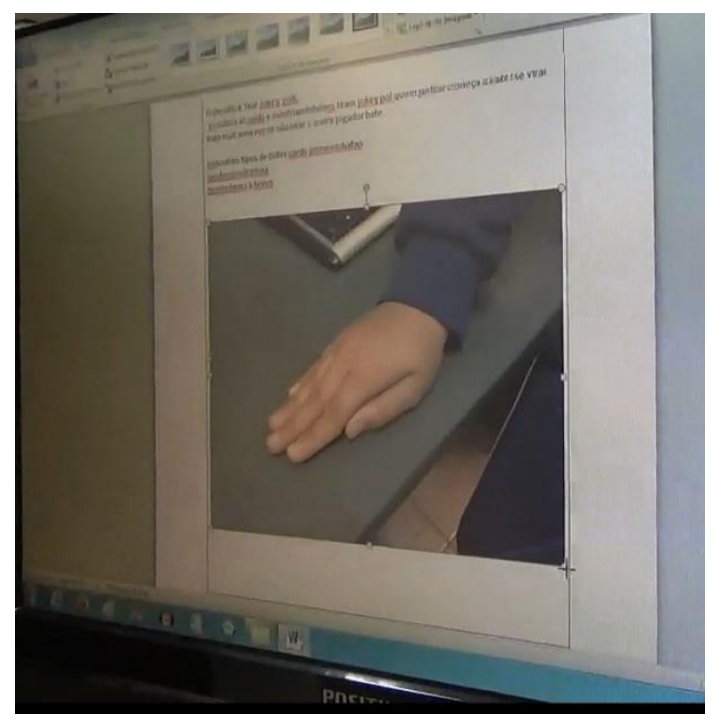

Inserida a foto, AE maneja o cursor do mouse trabalhando com o movimento de arrastar as arestas da figura, conforme explicado pela professora, com o intuito de ajustá-la à diagramação do texto, alterando seu tamanho. Abaixo da imagem, ela insere a legenda "Figura 1:mãozinha".

Figura 42 - AE/AG: Ajuste da foto conforme diagramação do texto e escrita de legenda

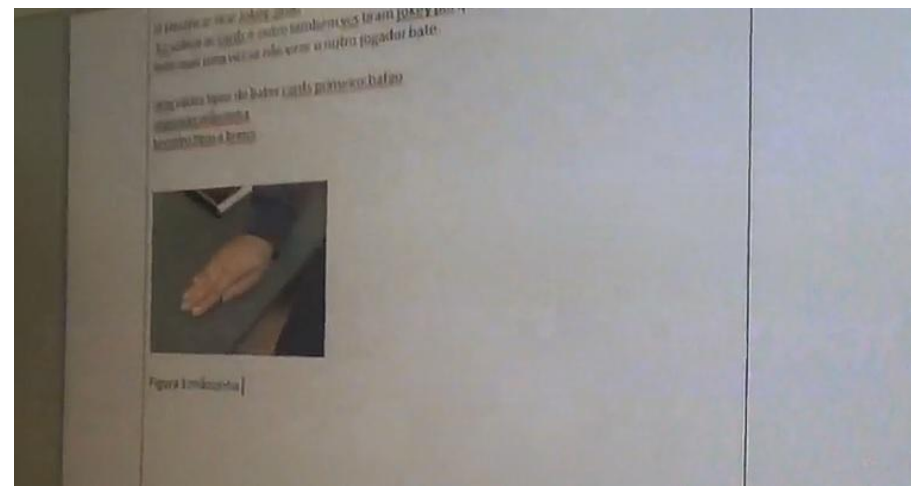

${ }^{93}$ O termo "navegar" é utilizado como sinônimo de consultar vários hipertextos, utilizando os links neles contidos, a fim de passar de um para outro e, em geral, encontrar o conteúdo procurado. 
A seguir (linhas 06 e 07), AE insere a segunda foto executando os mesmos procedimentos, tanto para buscar a figura no gerenciador de arquivos quanto para ajustá-la à diagramação do texto. No entanto, ao ser inserida a segunda foto, o editor de texto inaugurou uma segunda página do documento pelo fato de a imagem estar em tamanho desproporcionalmente grande quando comparado ao leiaute da página. Assim, quando $\mathrm{AE}$ ajustou o tamanho da foto, o documento foi reduzido novamente para uma página, o que causou um problema para os alunos, que pensaram que haviam perdido o texto produzido (linhas 07 e 08).

Figura 43 -AE/AG: Problemas com a rolagem de tela (paginação)

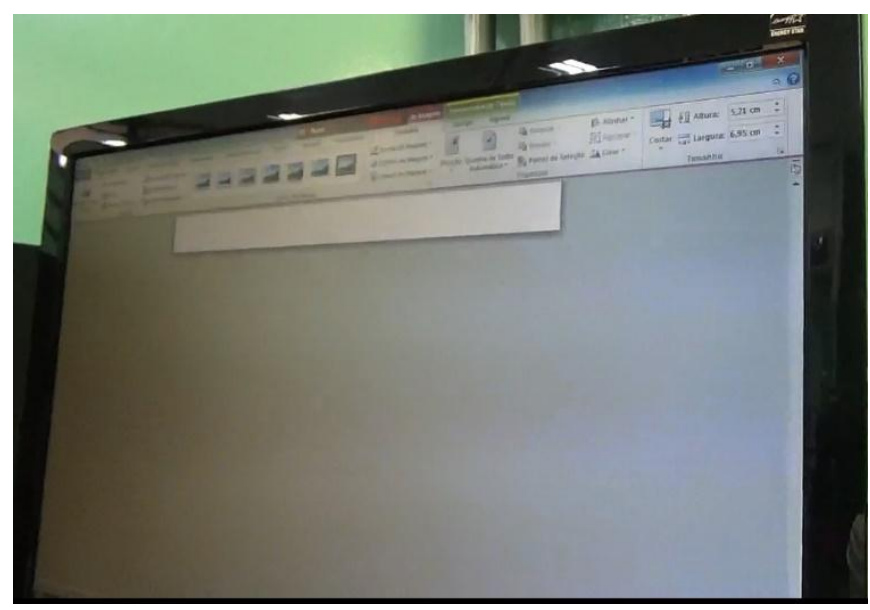

Demonstrando conhecimento acerca dos botões da Barra de Ferramentas de Acesso Rápido $^{94}$, AE clica no botão desfazer digitação, e a foto volta ao tamanho inicial, ocupando a segunda página do documento. Mesmo estando em tamanho desproporcional, AG enuncia "melhor assim" (linha 09), referindo-se que é melhor manter a foto, mesmo que em tamanho grande, a correr o risco de perderem o texto. A partir das tentativas frustradas, os alunos solicitam auxílio à professora e explicam a ela que estão executando os procedimentos ensinados ao início da aula, conforme $A E$ enuncia na linha 10: “A profa falou assim que é pra

\footnotetext{
${ }^{94}$ A Barra de Ferramentas de Acesso Rápido fica localizada imediatamente acima da Faixa de Opções, no canto superior esquerdo da tela. É um recurso personalizável e inclui um conjunto de comandos independentes da guia, na Faixa de Opções em exibição no momento. Nos computadores do laboratório, as opções de comandos era Salvar, Desfazer e Repetir Digitação.
} 
fazer assim né ((desliza o dedo na tela)) quando coisa", se referindo à ação de arrastar o cursor do mouse desde uma das arestas da foto.

Figura 44 - AE/AG: AE exemplificando a ação de ajustar o tamanho da imagem ao texto

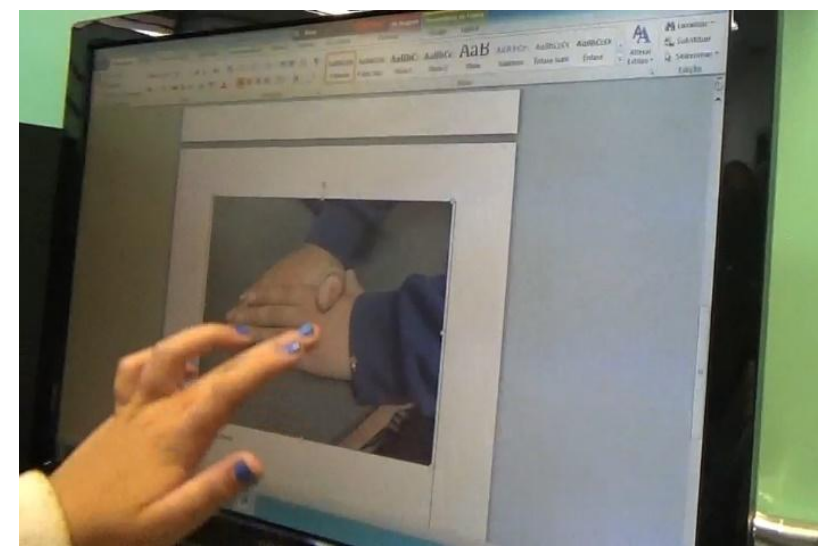

A professora confirma o procedimento e explica à aluna que é necessário utilizar a barra de rolagem (linha 14) disponível ao lado direito do editor de texto para acessar as páginas anteriores, pois ao inserir a foto, criou-se uma nova página, conforme fala da professora na linha 16: "É sobe um pouquinho é por que como a figura estava muito grande ela estava na outra página". A seguir, a professora explica que é necessário posicionar o cursor do mouse antes de realizar o procedimento de inserir a figura (linha 22). Assim que a professora se afasta, os alunos retomam os procedimentos indicados, iniciando pelo posicionamento do cursor do mouse.

Figura 45 - AE/AG: Aluna apontando o espaço para a segunda figura na diagramação do texto

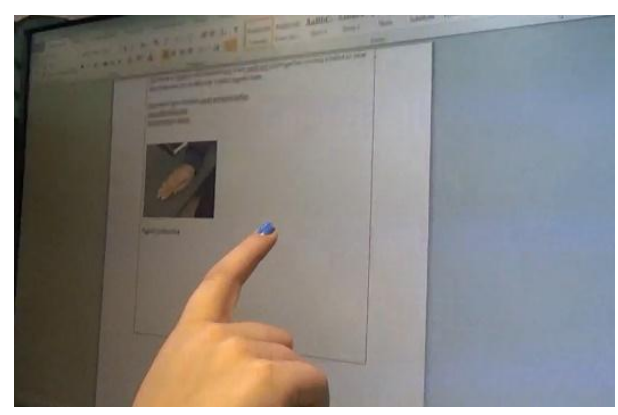


Após mais algumas tentativas frustradas (linha 25), os alunos conseguem inserir a segunda foto e posicioná-la conforme julgaram ser mais adequado aos propósitos comunicativos do texto.

Figura 46 - AE/AG: Segunda imagem ajustada à diagramação do texto

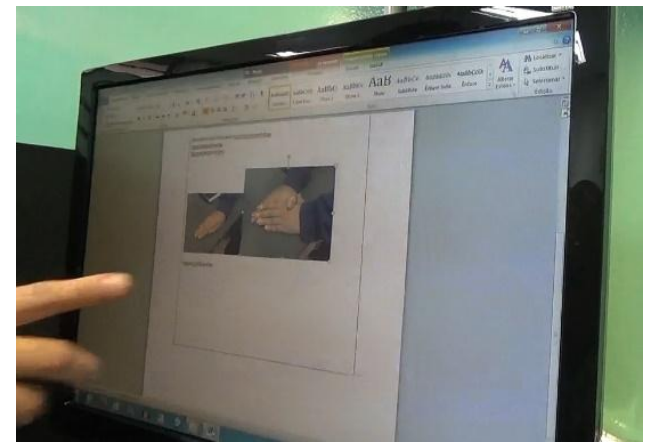

Por fim, utilizam a barra de espaço para realizar um último ajuste e inserem a legenda da segunda foto: "Figura 2:bafao". Após realizarem mais alguns ajustes no texto escrito, chamam novamente a professora para apresentar o resultado do trabalho. No entanto, a meta era inserir três figuras, o que é pontuado pela professora.

\section{Quadro 30 - Transcrição do OT técnico-gráfico AE/AG: inserção de fotos no texto}

\begin{tabular}{|c|c|c|c|}
\hline Tempo & Linha & Interlocutor & Transcrição \\
\hline \multirow[t]{6}{*}{$26^{\prime} 55^{\prime \prime}$} & 27 & $\mathrm{AE}$ & Professo:::ra \\
\hline & 28 & $\mathrm{PE}$ & Terminaram? Muito bom... e a outra foto vocês não vão colocar? \\
\hline & 29 & AG & Não sei \\
\hline & 30 & $\mathrm{PE}$ & É não tem... tem outra é o paredão... mãozinha e o bafão não é? \\
\hline & 31 & $A E$ & $\begin{array}{l}\text { ((abre o gerenciador de arquivos e insere a figura em tamanho } \\
\text { grande)) }\end{array}$ \\
\hline & 32 & AG & O loco:::: \\
\hline \multirow[t]{6}{*}{$27^{\prime} 30^{\prime \prime}$} & 33 & $\mathrm{AE}$ & Ai meu deus ((utiliza a barra de rolagem)) \\
\hline & 34 & AG & apaga \\
\hline & 35 & $\mathrm{AE}$ & $\begin{array}{l}\text { É vamos de novo por que eu ia colocar aqui essa coisa ((aluna aponta } \\
\text { a tela, mostrando a necessidade de reformular a ordem das figuras } \\
\text { de acordo com o texto)) (Figura 8) }\end{array}$ \\
\hline & 36 & AG & (incompreensível) \\
\hline & 37 & $\mathrm{AE}$ & Não ((posiciona o cursor por meio da tecla espaço)) \\
\hline & 38 & $\mathrm{AE}$ & $\begin{array}{l}\text { Ai vai ficar feio... ((insere novamente a figura grande e minimiza } \\
\text { arrastando a resta)) }\end{array}$ \\
\hline
\end{tabular}




\begin{tabular}{|l|l|l|l|}
\hline & 39 & AG & Acho que eu dei (incompreensível) \\
\hline & 40 & AE & $\begin{array}{l}\text { Calma meu filho tá aqui ó ((utiliza a barra de rolagem para localizar a } \\
\text { primeira página do texto)) }\end{array}$ \\
\hline & 41 & AG & Tá bom vou ficar bem quietinho \\
\hline 42 & AE & $\begin{array}{l}\text { Qual que é esse mesmo? ((pergunta enquanto redige a legenda da } \\
\text { terceira foto)) }\end{array}$ \\
\hline & 43 & AG & Paredão \\
\hline
\end{tabular}

O desenvolvimento da tarefa executada pelos alunos desvela um conjunto de novos saberes envolvidos no uso do editor de texto nas atividades de produção de textos. Apenas nos minutos analisados acima vemos questões relacionadas à leitura de ícones, pois os alunos precisaram manejar adequadamente abas e botões da faixa de opções e da Barra de Ferramentas de Acesso Rápido. Ao inserirem a segunda foto, não compreenderam a lógica de paginação do editor de texto e pensaram que tinham perdido o trabalho realizado até o momento. Foi necessário a intervenção da professora para fazê-los entender o funcionamento do editor, bem como o funcionamento da barra de rolagem para leitura e escrita em tela, manejando a barra por meio do mouse. Por diversas vezes, os alunos precisaram manejar o mouse adequadamente para posicionar o cursor e alcançar a diagramação desejada e, por fim, estratégias básicas de adequação e formatação das figuras a serem inseridas para a composição do texto final.

Assim, todos esses saberes foram acionados para que os alunos fossem bem-sucedidos na tarefa de inserir as figuras e, ainda, trabalhar a diagramação do texto, que seria posteriormente impresso. 
Produção de texto ao final da aula dupla $A E / A G$

O Desafio é Tirar Jokey polk,

Você coloca as cards e outro também vocês tiram jokey pol quem ganhar começa a bater se virar bate mais uma vez se não virar o outro jogador bate.

tem vários tipos de bater cards primeiro:bafao

segundo:mãozinha

terceiro: a brincs

quarto:paredao

a brincs não è igual a ganha que um bate e è dele a cards a brincs è quando um bate ele vira a cards e eles vai batendo, no final ele devolvi as cards do outro.

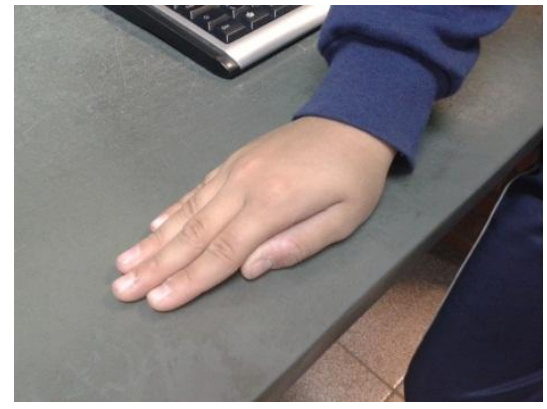

Figura 1:mãozinha

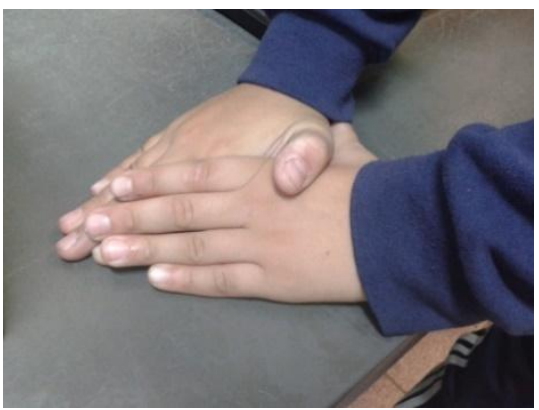

Figura 2:bafao

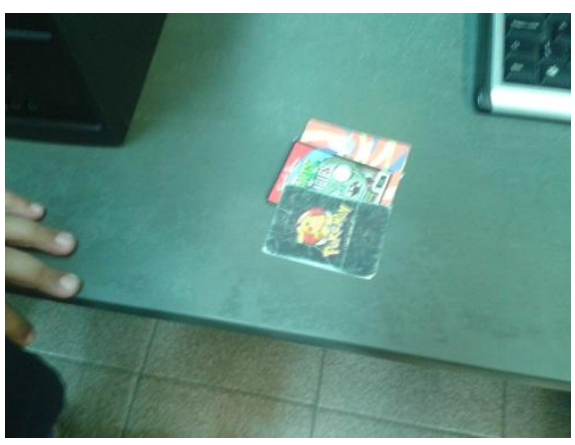

Figura 3:paredão 


\section{Discussão dos resultados}

Ao longo da análise, apresentamos o total de 24 objetos textuais que emergiram nas interações entre os alunos ao longo do desenvolvimento das atividades de produção de texto. Neste capítulo, iremos discutir os dados analisados na seção anterior esmiuçando-os a partir das três unidades de análise: i) os objetos textuais vinculados ao sistema alfabético e ortografia; ii) os objetos textuais que envolvem o uso da palavra em seu contexto textual/frasal; e iii) os objetos textuais suscitados a partir de questões envolvendo aspectos técnico-gráficos de usabilidade dos instrumentos - teclado e mouse -, bem como as especificidades do uso do editor de texto. Por fim, abordaremos aspectos relacionados aos modos como se configurou a interação didática e o movimento de inovações e permanências no interior dessas práticas analisadas.

\subsection{Objetos textuais envolvendo aspectos do domínio do sistema alfabético e das convenções ortográficas}

Os problemas enfrentados pelos alunos nesta primeira categoria somaram oito ocorrências. No interior desse conjunto, podemos apontar os seguintes objetos:

- $\quad$ segmentação;

- escrita de palavras com sílabas não canônicas;

- escrita de palavras desconhecidas;

- representações homofônicas;

- apoio na oralidade.

Dos problemas listados acima, os comentários envolvendo a segmentação de palavras foram os mais frequentes, totalizando três ocorrências. Nas duplas que apresentaram esses OTs, o aluno com mais dificuldade assumia o papel de escriba, e seu colega mais experiente, que atuava como ditante, teve em mais de uma ocorrência a ação de apontar os problemas vinculados à segmentação, como no caso das duplas $A B$ e $A V, A L A$ e $A R$ e ALF e AK. 
Abordando a segmentação, observamos no trabalho da dupla $A B$ e $A V$ o desenvolvimento desse movimento. Ao longo do processo de textualização, $A B$, que apresentava maiores conhecimentos acerca da língua escrita, dita o texto ao colega, que escreve algumas palavras aglutinadas - como "tirajoquenpo" em lugar de "tirar Jo-ken-po" -, e ao visualizar a escrita, $A B$ aponta o problema de maneira quase imediata. Do mesmo modo, observamos no trabalho de ALA e AR que a aluna com maior conhecimento da língua escrita, ALA, atua como revisora da escrita da colega e, mesmo ao longo da textualização, realiza a correção das palavras aglutinadas rapidamente, assim que observa o problema, como no caso de "bebendoumaágua", situação em que, oralmente, repete a escrita da colega salientando o artigo "uma", utilizando uma entonação enfática ao pronunciá-lo, "Bebendo UMA água", e demonstrando assim que se tratam de unidades com funções e significados distintos, portanto, deveriam ser grafadas separadamente.

Os dois casos mencionados acima mostram como é discrepante o desenvolvimento da consciência lexical entre alunos da mesma turma de 3ㅇano. Os pares mais experientes, dispondo de um repertório léxico da língua escrita maior que o dos colegas, realizam as adequações imediatamente, ou seja, caso estivessem redigindo um texto sozinhos, os alunos com maior desenvolvimento da consciência lexical tratariam a segmentação de palavras de maneira automatizada, enquanto os alunos com menor domínio da língua escrita ainda estão conquistando esse conhecimento.

Já no trabalho da dupla ALF e AK, a questão envolvendo segmentação ocorre no processo de revisão de texto, ou seja, inicia-se quando os alunos cessam a textualização e, guiados pelas marcações do corretor ortográfico do editor, realizam um retorno a determinados termos do texto. No caso específico dessa dupla, os alunos observam problemas de aglutinação em "aganhas", envolvendo portanto um termo específico do jogo, ou seja, uma palavra que não compõe seu léxico mental de palavras escritas, o que promove maiores problemas quando necessitam escrevê-la. Dentre os problemas de hipossegmentação, a aglutinação de palavras com função sintático-relacional - no caso do artigo - e palavras com função semântica - um substantivo - é bastante comum nessa fase do desenvolvimento da escrita. 
Essas considerações a respeito da segmentação de palavras desvelam uma das características inerentes dos escritores recém-alfabetizados. O apoio na oralidade ainda não permite que consigam analisar o critério morfológico da separação entre palavras, pois analisam a escrita fonologicamente. A conquista do automatismo da segmentação é bastante distinto do aprendizado do sistema de notação alfabética e vincula-se à apropriação do sistema ortográfico, ou seja, é muito mais que correlacionar letra-som, pois para o desenvolvimento da consciência fonológica é necessário que caminhem no desenvolvimento da consciência lexical de modo a construir um critério morfológico, avançando assim na aprendizagem das convenções da escrita, compreendendo que estas seguem regras outras daquelas da língua oral (MORAIS, 2002).

Observamos que os OTs envolvendo a escrita de sílabas não canônicas e o apoio na oralidade foram muito frequentes no trabalho desenvolvido pela dupla com maior dificuldade na escrita de palavras, ARA e ALU. É curioso observarmos também que, apesar do grande número de problemas envolvendo a segmentação de palavras, ARA e ALU não realizam nenhum comentário acerca dessa questão. Isso é um indicador de que a pouca familiaridade com a língua escrita e o forte apoio na oralidade ainda não permitiram que fizessem reflexões metalexicais - consciência morfológica -, que consiste exatamente em segmentar a linguagem oral em palavras (BARRERA; MALUF, 2003). Ainda, Soares aponta que o desenvolvimento da consciência morfológica apresenta seu desenvolvimento em uma etapa da aprendizagem da língua escrita posterior, quando é compreendido de maneira mais consolidada o "princípio alfabético e suficientemente desenvolvida a consciência fonológica" (SOARES, 2016, p. 156). Desse modo, podemos observar que ARA e ALU, apesar de grafarem palavras compostas por sílabas canônicas com relativo sucesso, empregam na escrita de cada termo a rota fonológica, sempre pronunciando em voz alta o som das letras que estão sendo digitadas, geralmente por mais de uma vez. Ao se depararem com dúvidas ortográficas, como no caso da escrita da palavra "vez", optam por buscar apoio na oralidade, elegendo a forma "veiz" como a mais correta, ou seja, remetem à pronúncia da palavra por não a possuírem em sua forma escrita no seu repertório léxico escrito, que, caso já a compusesse, poderia ser acessado pela memória de longo prazo. 
A escrita de palavras compostas por sílabas não canônicas também representou um problema para as duplas $A B$ e $A V$ ao se depararem com a forma escrita de uma palavra que utilizavam apenas oralmente, o termo "brinques", específico do jogo que redigiam as regras. Assim, se concentram exclusivamente na escrita dessa palavra, evocando uma série de estratégias voltadas ao reconhecimento das relações letra-som, pronunciando as sílabas em voz alta - no caso "BRIN" -, soletrando, lembrando de palavras iniciadas pela mesma sílaba e retomando regras ortográficas que já dominam, como o uso de $\mathrm{M}$ ou $\mathrm{N}$. Apesar das diversas estratégias, chegam à forma "primbrikis", aglutinando à palavra uma nova sílaba, "prim", que guarda uma série de relações com a sílaba que gerou o conflito, ou seja, a relação surda/sonora entre $\mathrm{P} / \mathrm{B}$ e o uso da regra ortográfica entre as letras $\mathrm{M} / \mathrm{N}$.

Os problemas envolvendo as relações homofônicas, no caso observado neste estudo, vinculam-se também à escrita de uma palavra que não compõe o repertório léxico escrito. No trabalho da dupla AGO e AW, o objeto textual incide na grafia da palavra "matança", a qual redigem "matancia", na qual os alunos, ao longo do processo de textualização, observam a marcação do corretor ortográfico do editor de texto, e AGO, que possui maior domínio das convenções ortográficas, já identifica a sílaba final "cia" como foco do problema a ser resolvido e empreende algumas tentativas de correção, recorrendo aos conhecimentos que já detém das convenções ortográficas, alternando o uso das letras C, S e Ç. Já AW, no decorrer da interação, busca o apoio na rota fonológica, repetindo em voz alta as sílabas que poderiam estar grafadas incorretamente e focando na sílaba medial "tan", repetindo-a diversas vezes. Assim, podemos inferir que AW, no processo de revisão ortográfica, focalizou o problema da nasalização, muito frequente em alunos com pouco domínio do sistema alfabético de escrita, e desconsiderou o problema da concorrência entre as letras C, S e Ç para a representação do fonema /s/, o que envolve maiores conhecimentos acerca das convenções ortográficas na escrita de palavras.

Em suma, a partir das ocorrências dos objetos textuais envolvendo a faceta linguística da aprendizagem da língua escrita, observamos que os alunos que apresentam mais conhecimento acerca da língua escrita já desenvolveram uma consciência lexical mais apurada, realizando procedimentos como a segmentação de maneira mais automatizada, localizando com mais facilidade focos que representam maiores dificuldades no interior da grafia de uma 
determinada palavra e recorrendo, com mais frequência, ao conhecimento de regras ortográficas que já dominam. Já os alunos com maior dificuldade recorrem à oralidade, ou seja, apoiam-se na relação letra-som, e mostram que precisam de intervenções para que consigam construir uma representação adequada dos diversos aspectos que convencionam a língua escrita.

\subsection{Objetos textuais envolvendo aspectos composicionais}

Os OTs suscitados nas interações entre as duplas emergiram especialmente nos processos de planejamento e textualização. Identificamos problemas relacionados a:

- dificuldades em textualizar o que se planeja oralmente;

- função sintática das palavras;

- concordância verbal;

- organização das informações no texto;

- estrutura frasal.

Os OTs voltados à competência composicional mais frequentes foram aqueles envolvendo as variações de uma palavra em relação ao seu contexto de uso. A dupla AL e AS apresentou dois problemas dessa natureza. No processo de textualização, AL realiza uma reflexão acerca de qual seria a forma mais adequada do uso do verbo "trapacear" no interior do período: "Não pode trapaça/trapacear". Nesse OT, o comentário de AL é ignorado pelo colega, que opta pela forma "trapaça" no texto escrito, embora ao realizar a leitura em voz alta utilize "trapacear". Logo em seguida, a mesma dupla se depara com o problema da concordância do verbo "bater" ao ser utilizado com o verbo "estar", assim, ao lerem o trecho produzido concordam que a forma mais adequada seria "está batendo" ou "tá batendo", no entanto, embora haja a reformulação oral, os ajustes na escrita não são realizados. Na correção, simplesmente alteram a forma "bate" por "bater", concentrando-se assim em uma questão ortográfica. De maneira semelhante, a dupla AGO e AW no processo de revisão do texto retoma o período grafado como "só bate com mãozinha" e na reformulação oral concorda que seria 
mais adequada a construção "só pode bater com mãozinha". No entanto, assim como a dupla anteriormente citada, AGO e AW não executam a inserção do verbo "poder" e concentram-se exclusivamente na correção ortográfica do verbo "bate", inserindo o R para sua forma no infinitivo. O mesmo OT é encontrado na interação dos alunos $A B$ e $A V$. Frente à necessidade de uma reestruturação da frase "tem que tira pra tira", os alunos corrigem oralmente a duplicação do verbo "tirar", mas não conseguem reformular a frase de modo que conquistem a sua adequação gramatical e acabam focando na necessidade de inserir o R final da forma infinitiva do verbo, ou seja, uma questão ortográfica.

O trabalho dessas duplas reencontra o que se atesta em Góes (2003) e Soares (2016), que afirmam que alunos na fase inicial da escrita tendem a se concentrar em aspectos ortográficos em detrimento de aspectos que demandam reflexões de caráter mais amplo, como ativar a consciência sintática, pois esta envolve o controle da compreensão, ou seja, implica que não se concentrem na grafia correta de uma palavra isolada, mas "sobretudo, da articulação sintática dos elementos linguísticos que compõem a frase ou o texto" (SOARES, 2016, p. 143). Assim, as duplas acabam por construir duas frases que podem ser consideradas agramaticais, embora as tenham corrigido adequadamente na formulação oral. Observe as redações finais:

AL/AS: "você tá bater" em lugar de "você tá batendo"

AGO/AW: "só bater com mãozinha" em lugar de "só pode bater com mãozinha"

$\mathrm{AB} / \mathrm{AV}$ : "tem que pra tirar joquempo" em lugar de "tem que tirar joquempo" ou "Pra tirar joquempo".

Em relação ao processo de planejamento, no desenvolvimento da primeira atividade de produção textual, a análise da interação da dupla AL e AS desvelou, a partir de uma intervenção feita pela professora, como os alunos são capazes de formular o texto oralmente, mas apresentam muitas dificuldades ao redigi-lo. Na formulação oral, utilizam gestos, expressões informais - como "tipo" - e repetições. No entanto, ao se colocarem na posição de escritores, as dificuldades em textualizar o conteúdo, facilmente explicitado na modalidade oral, são de diversas ordens. A principal delas consiste na tendência a não explicitar informações importantes em virtude da não construção de um interlocutor modelo adequado, ou seja, o jovem escritor tem dificuldades em projetar a importância do processo de construção da compreensão por parte do leitor. Essa constatação reencontra o estudo de Val e Barros sobre a 
produção de textos escritos injuntivos quando afirmam que "traz dificuldades para as crianças na medida em que requer a representação verbal, lexicalizada e sintetizada, de imagens visuais que se traduziriam mais facilmente por gestos e movimentos" (VAL; BARROS, 2008, p. 164).

No que tange aos OTs vinculados à organização das informações no texto, observamos que, com exceção de $A L$ e AS e ARA e ALU, todas as duplas optam por organizar o elenco (TRAVAGLIA, 1991) do texto instrucional em itens numerados. É provável que não tenhamos encontrado essa especificidade em AL e AS e ARA e ALU, pois os trechos analisados referem-se à primeira versão da produção textual. De todo modo, nas demais duplas, observamos que houve uma reflexão metatextual, geralmente promovida pelo integrante com maior domínio da língua escrita, acerca da organização cronológica dos itens, bem como sobre a progressão das informações, demonstrando cuidado para que elas não incidissem em repetições.

É o caso do trabalho de $A B$ e AV. A dupla inicia a interação analisada reordenando as informações, em um processo de revisão da primeira escrita. Essa reflexão foi promovida por $A B$, ditante, que apresentava maiores conhecimentos de escrita. Nessa mesma dupla, ao longo da textualização, há uma sugestão de inserção de conteúdo feita por AV. A colega AB desconfia que a informação já tivesse sido explicitada ao início do texto, pois o início da construção da frase era praticamente idêntica a outra já utilizada, mas AV argumenta "quem ganha o Jô-kenpo bate primeiro", e assim concordam que era uma informação nova e relevante para a composição textual. Esse movimento observado pode ser identificado como um comportamento de reflexão metatextual, pois os alunos apresentaram uma regulação sobre o texto e vislumbraram a construção das estratégias de compreensão por parte do leitor (SOARES, 2016).

\subsection{Objetos textuais envolvendo aspectos técnico-gráficos}

A partir da análise dos dados, pudemos observar que o nível de domínio técnico dos alunos em relação ao uso do teclado, do mouse e do editor de texto varia muito (cf. DUDENEY; HOCKLY; PEGRUM, 2016). Os comentários realizados pelos alunos acerca de problemas 
relacionados ao manejo das ferramentas foram frequentes e apresentaram diversos níveis de dificuldade. Para parte dos alunos, comandos considerados elementares, como o manejo do ponteiro, o posicionamento do cursor e a função das teclas Enter e Backspace, eram praticamente desconhecidos, como no caso da interação analisada entre ARA e ALU, que demonstravam dificuldades até mesmo em encontrar as letras no teclado, bem como as dificuldades apresentadas por AR, que precisava constantemente do auxílio da colega ALA para realizar esses procedimentos. No trabalho da dupla ALF e AK, na qual AK era a integrante com menos experiência no uso do teclado e do mouse, ALF, no processo de revisão textual envolvendo a segmentação de palavras escritas de maneira aglutinada, apontava na tela onde a colega deveria posicionar o cursor do mouse e realizar a separação das palavras. Na tentativa de posicionar o cursor corretamente, AK chega a pronunciar "gente é difícil fazer isso", no entanto, com o auxílio do colega, consegue executar o procedimento. Alguns instantes depois, AK e ALF encontram outro problema de segmentação. Apesar de aparentemente repetirem o procedimento, AK acaba por selecionar a letra ao invés de simplesmente posicionar o cursor, o que implica, ao apertar a tecla espaço, o apagamento da letra.

Já para os alunos que apresentavam maiores conhecimentos no manejo do teclado e do mouse, as dúvidas recaíam sobre como inserir os diacríticos, especialmente quando se tratava de sincronizar o uso da tecla com a letra e outra tecla com o diacrítico desejado. É interessante o movimento empreendido por AGO e AW, que tentam dividir a tarefa: um aciona a tecla com o diacrítico, e o outro, a tecla com a letra. Foram necessárias diversas tentativas até que conseguissem inserir o diacrítico correto na letra correspondente.

No desenvolvimento da atividade 7, que demandava maior habilidade no manejo técnico dos instrumentos e do próprio editor de texto, pois incidia na inserção de fotos e, consequentemente, a diagramação do texto, a dupla $A E$ e $A G$, mesmo apresentando bons domínios técnicos - como o manejo adequado das abas da faixa de opções, boa navegação entre as janelas do gerenciador de arquivos em busca da foto desejada, a utilização do comando "desfazer" quando acreditavam ter feito algo errado -, apresentou problemas que podem ser considerados bastante simples, como compreender a lógica de funcionamento de paginação do 
editor de textos - a rolagem - e o recurso da "barra de rolagem" para retornar à página anterior.

Apesar das dificuldades enfrentadas pelos alunos, é importante salientarmos que o uso do teclado feito por eles no desenvolvimento do trabalho com o editor de texto esteve circunscrito a apenas uma das diferentes categorias de teclas do teclado convencional ${ }^{95}$, ou seja, as atividades planejadas não previam ações que demandassem conhecimentos mais complexos acerca da usabilidade do editor de texto ou do teclado. Nas tarefas propostas, os alunos precisaram utilizar apenas as chamadas "teclas de digitação", que incluem as teclas de letras, números, pontuação e símbolos, ou seja, aquelas encontradas nas máquinas de escrever tradicionais. Nesse grupo, estão as teclas Shift, Caps Lock, Tab, Enter, a barra de espaços e o Backspace. Poderíamos também pressupor que seria desejável o manejo das chamadas "teclas de navegação", como as teclas de seta, Page up e Page down, usadas para a movimentação no editor de texto, que poderiam ter sido utilizadas em lugar do mouse e da "barra de rolagem", no entanto, isso demandaria outros saberes ainda mais sofisticados. Seria interessante, desse modo, pensarmos em uma progressão no que tange ao ensino da funcionalidade, tanto dos diferentes conjuntos de teclas agrupadas por suas funções quanto do próprio editor de texto, ao longo do ensino da produção de textos com o uso do editor digital no Ensino Fundamental I e II. Conforme salienta Buzato:

Dentre as informações de que o usuário precisa dispor para o uso eficaz do teclado estão não apenas o significado de cada uma das teclas, como determinados modos de utilizá-las para fins específicos. As teclas "delete" e "back space" por exemplo, embora tenham funções semelhantes (apagar) devem ser usadas de maneiras particulares. Para apagar usando "delete" o usuário deve posicionar o cursor antes do texto a ser apagado. Já a tecla "back space" quando acionada, apaga o texto posicionado antes do cursor. (BUZATO, 2001, p. 149).

\footnotetext{
${ }^{95}$ As teclas são divididas de acordo com sua função. De acordo com o site da Microsoft, além do grupo denominado "teclas de digitação" temos outros quatro grupos: as "teclas de controle", que são usadas sozinhas ou combinadas com outras teclas para executar determinadas ações, como Ctrl, Alt e Esc; as "teclas de função", que são usadas para executar tarefas específicas, como F1, F2, F3 etc. até F12, com funcionalidade diferente de um programa para outro; as "teclas de navegação" são usadas para a movimentação em documentos ou páginas da Web e ao editar texto e incluem as teclas de seta, Home, End, Page Up, Page Down, Delete e Insert; e, por fim, o "teclado numérico", que é útil para inserir números rapidamente e onde as teclas estão agrupadas em um bloco, como uma calculadora convencional ou uma calculadora mecânica.
} 
A partir da análise dos dados, podemos afirmar que os alunos que apresentavam maiores dificuldades na escrita de palavras eram os mesmos que não conseguiam resolver problemas técnicos básicos, como posicionar o cursor e passar de uma linha a outra - como no caso de ARA, ALU, AR, AK. Essa dificuldade está muito atrelada à familiaridade que os alunos detêm com o instrumento. Para exemplificar, apresentaremos as imagens de como os alunos posicionam as mãos no teclado. Observe na Figura 47 como o aluno $A L$ - dupla $A L$ e $A S$ e que apresentava um domínio razoável da língua escrita - demonstra um posicionamento das mãos bastante adequado, utilizando a maior parte dos dedos para a digitação.

Figura 47-AL: Manuseio do teclado

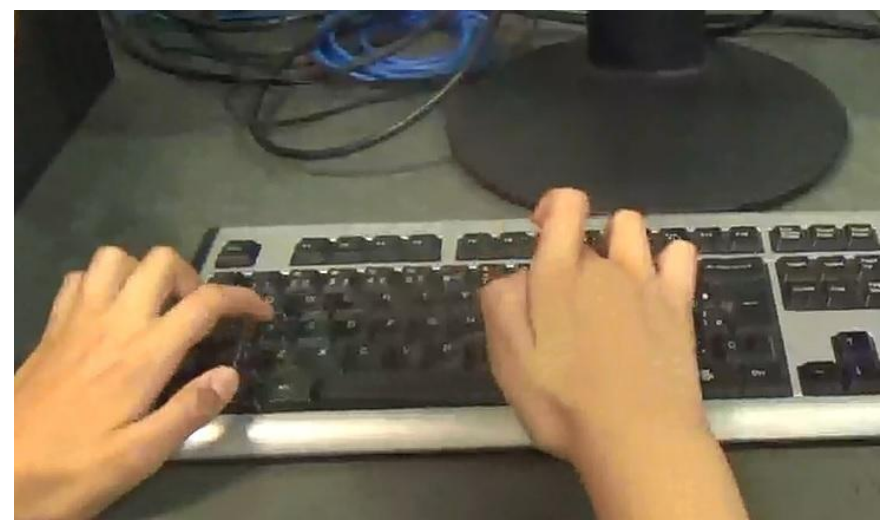

Já na dupla ALU e ARA, que apresentou as maiores dificuldades na escrita de palavras, observamos um manejo bastante limitado do teclado, fazendo uso dos dedos indicador e polegar (Figura 48).

Figura 48 - ARA: Manuseio do teclado

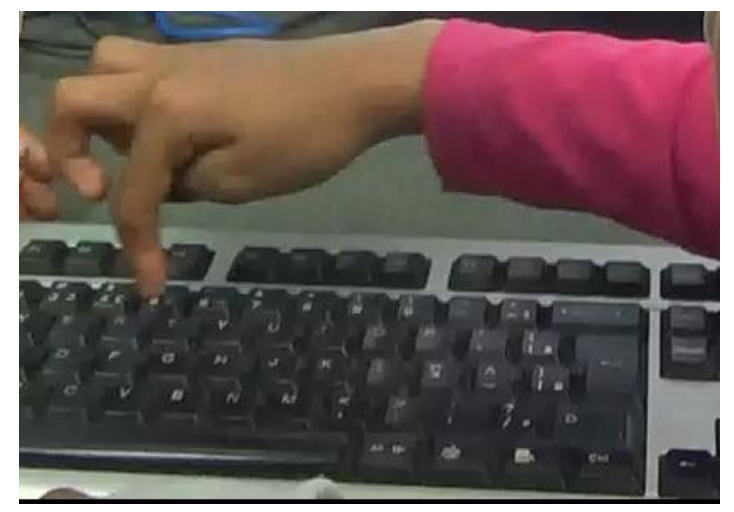


Figura 49-ALU: Manuseio do teclado

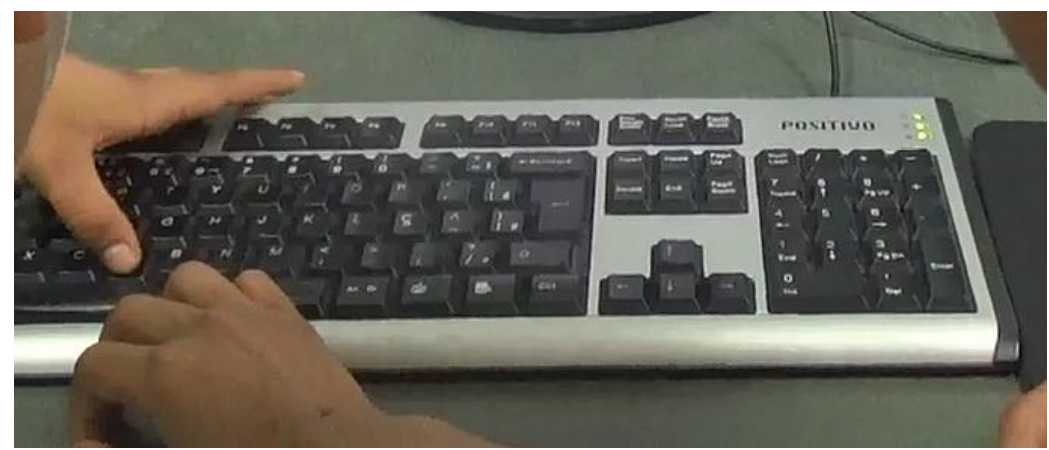

Observamos também que o gesto de apontar na tela de modo a localizar a si ou ao parceiro de escrita espacialmente foi frequente. A manutenção do toque do dedo sobre o suporte de escrita remete ao gesto da escrita com lápis ou caneta e papel, conforme foi observado por usuários adultos em Buzato:

Notou-se também, ainda com relação ao manuseio do conjunto mouse, teclado e tela, que Teresa tendia a mimetizar com gestos e palavras a velha mecânica corporal da escrita com lápis e papel. No videoteipe, nota-se que Teresa, inicialmente, passa o dedo indicador sobre a tela para mostrar a que se refere em sua fala ou mesmo quando está procurando uma palavra no texto ou um ícone na área de trabalho. (BUZATO, 2001, p. 151).

É importante salientarmos que nos suportes aos quais temos acesso na atualidade, o teclado é o principal instrumento para inserir informações no computador. Quanto mais o usuário produz conteúdo, maior uso do teclado ele fará. Já os usuários que se restringem a consumidores de conteúdo, pouco ou nenhum uso farão do teclado, podendo executar todas as ações por meio do mouse ou do próprio dedo - no caso dos dispositivos que operam com tela sensível ao toque.

\subsection{A interação e a relação didática}


No desenvolvimento das atividades de produção escrita desenvolvidas na geração dos dados, pudemos observar um significativo movimento de inovações. Retomando o estudo de Vidal $(2009$, p.28) no qual a partir da análise de fotos de diferentes épocas a autora salienta a notável permanência dos elementos estruturantes da sala de aula, podemos destacar quais as mudanças que a organização do ambiente com o uso de dispositivos descentralizados imprimiram nas relações didáticas.

[...] identificamos é a notável permanência dos elementos estruturantes da organização das salas de aula: a distribuição dos alunos em filas e voltados para a mesma direção; a existência de suportes da escrita, como folhas soltas, cadernos e quadros-negros; a utilização de objetos para escrever, como giz, lápis e canetas; a posição corporal dos estudantes, sentados em cadeiras e com os braços apoiados em mesas, e dos professores, em pé. (VIDAL, 2009, p. 28).

O primeiro ponto é a distribuição dos alunos em fileiras voltados a uma mesma direção. Nas interações analisadas, os alunos tem sua atenção voltada para a tela e pouco se voltam para buscar a atenção das professoras. Quando necessitam de auxílio, as professoras se deslocam até o local em que os alunos estão trabalhando. Assim podemos assinalar uma significativa diferença nos descolamentos. O segundo ponto ao qual Vidal chama nossa atenção refere-se a permanência do uso de folhas soltas, cadernos, lápis e canetas. Em nossos dados esses instrumentos que não foram utilizados. A circulação das tarefas dava-se pelo envio do arquivo do editor de textos desde o servidor operado pela professora. Quando precisavam recuperar uma tarefa feita em outra ocasião, ao invés de abrirem seus cadernos ou livros, os alunos recorriam à pastas específicas do gerenciador de arquivos. 


\section{CONCLUSÃO}

Em uma época em que o papel era extremamente caro e os textos que circulavam eram escassos, as técnicas de repetição exaustiva da leitura de textos conhecidos de memória e, posteriormente, da soletração atuando como um "substituto oral do gesto gráfico", o ensino da leitura tinha como objetivo saber ler para defender a sua fé. Quando a relação da sociedade com os textos, manuscritos e impressos, começa a mudar, ou seja, quando há um incremento na quantidade e na diversidade de textos circulando socialmente, observam-se os primeiros fracassos no ensino da leitura. Nesse contexto, o ensino da escrita começa a penetrar, ainda que de maneira lateral, nas práticas escolares, bastante em virtude do barateamento do papel e com o advento da pena metálica.

Ao longo processo de inserção da escrita na escola elementar verificamos a criação de utensílios diversos que possibilitaram toda uma reordenação da relação didática: o quadro negro permitiu que diversos alunos utilizassem um mesmo material para leitura e tivessem sua atenção em uma única direção, o caderno que se constituiu como principal elemento de organização e também como prova material do trabalho de ensino e aprendizagem e os exercícios envolvendo a escrita conformaram a forma escolar tal qual a conhecemos hoje: alunos sentados engajados no trabalho de copiar, atentos a ditados e redigindo textos em folhas que deverão ser entregues para que sejam objeto de avaliação e possibilitem sua progressão nos próximos anos da escolaridade.

Uma sala de aula organizada com dispositivos comunicativos descentralizados, como no caso do ambiente em que os dados foram gerados, acarreta mudanças significativas no tempo, espaço e nas relações didáticas. Para o desenvolvimento das tarefas é necessário que o professor saiba manejar o computador que atua como servidor e compreender o funcionamento da intranet, de modo que consiga projetar as tarefas nas telas de cada dupla de alunos. É necessário que se desenvolvam novos modos de armazenamento das atividades: já que não se utiliza cadernos ou folhas soltas, como acompanhar o desenvolvimento dos alunos? Assim, o manejo de pastas no interior do sistema operacional - o gerenciador de arquivos-, no caso dessa pesquisa, foi uma solução encontrada para que os alunos acessassem suas 
produções textuais e que as professoras também pudessem ter acesso a elas para o acompanhamento do desenvolvimento dos alunos.

Pouco se pensa nas alterações que o uso de novos artefatos promove na interação em sala de aula, principalmente em turmas dos anos iniciais. A popularização da fotocópia e dos livros didáticos implicaram maiores transformações nos anos finais tem em vista que o Ciclo de Alfabetização ainda se encontra bastante circunscrito ao ensino do traçado de letras, a aprendizagem do uso do caderno e como proceder para realizar cópias e o preenchimento de avaliações. De fato, há toda uma reordenação interacional quando se insere a tecnologia digital na escola. A primeira e mais simples delas reside no mero ato de grafar letras, no entanto, vimos que a escola continua focada em tarefas de treino das letras. A manutenção de determinadas práticas escolares não dependem exclusivamente de escolhas do professor, mas perduram exatamente por serem economicamente viáveis e exequíveis no interior da lógica escolar.

Ao pensarmos especificamente no processo de aprendizagem da escrita desses alunos que acabaram ou estão em processo de consolidação de seus conhecimentos acerca da escrita de palavras, observamos pela análise das dificuldades comentadas pelos alunos que seria interessante propor situações didáticas nas quais eles possam refletir sobre a função das palavras no interior dos textos ou em como a diagramação e o uso de diferentes elementos multissemióticos atuam para construir os sentidos pretendidos. Ao oferecermos outros recursos que permitem aos alunos desvencilhar-se do ato de grafar as letras podemos propiciar novas formas de interação com o texto e, ainda, permitir que vislumbrem novas possibilidades de interação do futuro leitor com o texto que estão produzindo: explorar o uso de cores, figuras, formas diferenciadas de diagramação, dentre outras possibilidades.

Hoje em dia, qualquer pessoa adulta que utilize a escrita para o trabalho, para o estudo ou para se comunicar com quaisquer instâncias sociais de maneira formal redige seu texto utilizando um dispositivo digital por meio de um teclado, periférico ou em tela sensível ao toque. Redigir bem um texto manejando esse instrumento de maneira adequada configura, muitas vezes, o sucesso comunicativo do escritor. 
Desse modo, esperamos que este estudo tenha contribuído para a reflexão: caberia a escola o ensino do manejo dos instrumentos de escrita da atualidade? Apregoa-se que os alunos nascidos nas últimas duas décadas desenvolvem uma espécie de "autoensino" quando se trata de uso de dispositivos digitais. No entanto, os usos dos dispositivos podem ficar circunscritos ao consumo. Os dados nos mostraram que os alunos com maior dificuldade na aprendizagem da escrita são os mesmos que detém pouca ou quase nenhuma familiaridade com o uso do computador. Mesmo os alunos que apresentam alguma experiência com o uso das ferramentas costumam utilizá-las com objetivos de entretenimento e consumo. Sendo assim, a partir das reflexões ensejadas nesse estudo, acreditamos que seja necessário proporcionar aos alunos tarefas com foco no desenvolvimento de conhecimentos instrumentais voltados a objetivos educacionais e profissionais, bem como para desenvolverem uma compreensão mais ampla das possibilidades e limitações que ferramentas tecnológicas disponibilizam para a produção de conteúdos que circulam na sociedade.

Enfim, esperamos que esta pesquisa tenha possibilitado pontuar alguns dos novos gestos vinculados à escrita que o uso dos dispositivos digitais acarretam quando postos em funcionamento em aulas voltadas a produção de textos. Salientamos que, muito mais que a iniciativa docente, o uso desses dispositivos está intimamente implicado com o que é exequível no interior da lógica de funcionamento da escola, contexto em que os docentes, que em meio a permanências e inovações, hibridando aspectos que consideram positivos e funcionais à práticas já sedimentadas da cultura escolar, remodelam suas práticas entre o que é possível de ser incorporado e o que é preciso ser descartado para o funcionamento estabelecido pela instituição. (VIDAL, 2009) 


\section{REFERÊNCIAS BIBLIOGRÁFICAS}

ABAURRE, Maria Berna dete Marques; FIAD, Raquel Salek; MAYRINK-SABINSON, Maria Laura Trindade. Cenas de aquisição da escrita: o sujeito e o trabalho com o texto. Campinas: Mercado de letras, 2006.

ALFABETIZAÇÃO DIGITAL. In: GLOSSÁRIO Ceale - termos de alfabetização, leitura e escrita para educadores. Belo Horizonte: Fae/UFMG, 2014. Disponível em:

http://www.ceale.fae.ufmg.br/app/webroot/glossarioceale/verbetes/alfabetizacao-digital.

ARAÚJO, Júlio César. Os gêneros digitais e os desafios de alfabetizar letrando. Trab. Ling. Aplic., Campinas, v. 46, n. 1, p. 79-92, jan./jun. 2007.

BALSLEV, Kristine; SAADA-ROBERT, Madelon. Les microgenèses situées. Unités et procédés d'analyse inductive-déductive. Recherches Qualitatives, v. 26, n. 2, p. 85-109, 2006.

BAPTISTA, Maria Adriana da Costa; VIANA, Fernanda Leopoldina; BARBEIRO, Luís Felipe. 0 ensino da escrita: dimensões gráfica e ortográfica. Lisboa: Ministério da Educação/DirecçãoGeral de Inovação e Desenvolvimento Curricular, 2011.

BARBEIRO, Luís Filipe; PEREIRA, Luisa Álvares. O ensino da escrita: a dimensão textual. Lisboa: Ministério da Educação/Direcção-Geral de Inovação e de Desenvolvimento Curricular, 2007.

BARRA, Valdeniza Maria Lopes. A lousa de uso escolar: traços da história de uma tecnologia da escola moderna. Educar em Revista, Curitiba: Editora UFPR, n. 49, p. 121-137, jul./set. 2013.

BARRERA, Sylvia Domingos; MALUF, Maria Regina. Consciência metalinguística e alfabetização: um estudo com crianças da primeira série do ensino fundamental. Psicologia: Reflexão e Crítica, 2003, 16(3), p. 491-502.

BECHARA, Evanildo. Moderna gramática portuguesa. 37. ed. Rio de Janeiro: Lucerna, 2004.

BIZELLI, José Luis; SEBASTIAN-HEREDERO, Eladio. Educação e inovação: o desafio da escola brasileira. Tendências Pedagógicas, n. 28, p. 55-66, 2016.

BOTO, Carlota. A liturgia escolar na Idade Moderna. 1. ed. Campinas: Papirus, 2017.

BRANDÃO, Carlos Rodrigues. BORGES, Maristela Correa. A pesquisa participante: um momento da educação popular. Rev. Ed. Popular, Uberlândia, v. 6, p. 51-62, jan./dez. 2007.

BRASIL. Constituição da República Federativa do Brasil. Brasília, DF: Senado Federal, 1988. 
. Lei no 9.394, de 20 de dezembro de 1996. Estabelece as diretrizes e bases da educação nacional. Legislação. Disponível em: www.planalto.gov.br. Acesso em: 25 jun. 2003.

. Lei no 10.436, de 24 de abril de 2002. Dispõe sobre a Língua Brasileira de Sinais - Libras e dá outras providências. Legislação. Disponível em:

http://www.camara.gov.br/sileg/integras/821803.pdf. Acesso em: 14 maio 2018.

. Ministério da Educação. Base nacional comum curricular. Brasília, DF, 2018. Disponível em: http://basenacionalcomum.mec.gov.br/download-da-bncc/. Acesso em: 15 abr. 2018.

. Ministério da Educação. Secretaria de Educação a Distância. Cartilha: recomendações para a montagem de laboratórios de informática nas escolas urbanas. Brasília, DF, 2008. Disponível em:

http://www.dominiopublico.gov.br/pesquisa/DetalheObraForm.do?select_action=\&co_obra=81 786. Acesso em: 13 mar. 2015.

BUZATO, Marcelo El Khouri. O letramento eletrônico e o uso do computador no ensino de língua estrangeira: contribuições para a formação de professores. 2001. 189 p. Dissertação (Mestrado em Linguística) - Universidade Estadual de Campinas, Campinas, 2001.

CAGLIARI, Luiz Carlos. A escrita no século XXI - ou, talvez, além disso. In: CAGLIARI, Luiz Carlos; MASSINI-CAGLIARI, Gladys. Diante das letras: a escrita na alfabetização. Campinas: Mercado de letras, 1999a.

. Alfabetização e linguística. São Paulo: Scipione, 2009.

. Breve história das letras e dos números. In: MASSINI-CAGLIARI, Gladis; CAGLIARI, Luiz Carlos. Diante das letras: a escrita na alfabetização. Campinas: Mercado de Letras/Associação de Leitura do Brasil (ALB); São Paulo: Fapesp, 1999b. p. 163-186.

CALIL, Eduardo. O sentido das palavras e como eles se relacionam com o texto em curso: estudo sobre comentários semânticos feitos por uma díade de alunas de 7 anos de idade. Alfa, São Paulo, v. 60, n. 3, p. 531-555, 2016.

CALIL, Eduardo; AMORIM, Kall Anne and LIRA, Lidiane. Letramento e processo de escritura de alunos recém-alfabetiza dos. Cad. Cedes, Campinas, v. 33, n. 89, p. 73-89, jan./abr. 2013.

CALIL, Eduardo; PEREIRA, Luísa Álvares. Reconhecimento antecipado de problemas ortográficos em escreventes novatos: quando e como acontecem. Alfa, São Paulo, v. 62, n. 1, p. 91-123, 2018. 
CARDOSO, Cancionila Janzkovski. A pontuação como recurso de textualização: as descobertas de uma criança. In: VAL, Maria da Graça Costa; ROCHA, Gladys (Org.). Reflexões sobre práticas escolares de produção de texto: o sujeito-autor. 1. ed. Belo Horizonte: Autêntica; Ceale/Fae/UFMG, 2008. p. 109-133.

CARVALHO, Liliane Maria Teixeira de; MONTEIRO, Carlos Eduardo Ferreira. Reflexões sobre implementação e uso de laboratórios de informática na escola pública. Roteiro, Joaçaba, v. 37, n. 2, p. 343-360, jul./dez. 2012.

CHARTIER, Anne-Marie. Exercícios escritos e cadernos de alunos: reflexões sobre práticas de longa duração. Tradução de Ana Maria de Oliveira Galvão e Ceres Leite Prado. In: Práticas de leitura e escrita: história e atualidade. Belo Horizonte: Autêntica; Ceale/Fae/UFMG, 2007. p. 2166.

Os três modelos de leitura entre os séculos XVI e XXI: como as práticas sociais transformam os métodos de ensino? Tradução e revisão técnica de Ceres Leite Prado. Rev. Bras. Hist. Educ., Maringá, v. 16, n. 1 (40), p. 275-295, jan./abr. 2016.

1980-2010: trinta anos de pesquisas sobre a história do ensino da leitura. Que balanço? In: MORTATTI, Maria do Rosário Longo (Org.). Alfabetização no Brasil: uma história de sua história. São Paulo: Cultura Acadêmica; Marília: Oficina Universitária, 2011. p. 49-67.

CHARTIER, Anne-Marie; HÉBRARD, Jean. Método silábico e método global: alguns esclarecimentos históricos. Revista História da Educação, Pelotas: Asphe/Fae/Ufpel, v. 10, p. 141-154, out. 2001.

CHARTIER, Roger. A aventura do livro: do leitor ao navegador. São Paulo: Editora da Unesp; Imprensa Oficial, 1999.

Do códice ao monitor: a trajetória do escrito. Estud. Av., São Paulo, v. 8, n. 21, p. 185199, ago. 1994.

CHERVEL, André. História das disciplinas escolares: reflexões sobre um campo de pesquisa. Teoria e Educação, n. 2, p. 177-229, 1990.

COLELLO, Silvia M. Gasparian. Alfabetização ou alfabetização digital? International Studies on Law and Education, Cemoroc-Feusp/IJI-Univ. do Porto, 23 maio/ago. 2016.

COMPUTAÇÃO em nuvem. In: Wikipédia - a enciclopédia livre. Disponível em: https://pt.wikipedia.org/wiki/Computa\%C3\%A7\%C3\%A3o_em_nuvem. 
CÓPIA. In: GLOSSÁRIO Ceale - termos de alfabetização, leitura e escrita para educadores. Belo Horizonte: Fae/UFMG, 2014. Disponível em:

http://www.ceale.fae.ufmg.br/app/webroot/glossarioceale/verbetes/copia.

CORDEIRO, Glaís Sales. Escrita de textos argumentativos em classes suíças francófonas do ensino médio: uma análise multifocal do objeto ensinado. Raído, Dourados, v. 9, n. 18, p. 113136, jan./jun. 2015.

COSCARELLI, Carla Viana. Alfabetização e letramento digital. In: COSCARELLI, Carla Viana; RIBEIRO, Ana Elisa (Org.). Letramento digital: aspectos sociais e possibilidades pedagógicas. 3. ed. Belo Horizonte: Autêntica; Ceale/Fae/UFMG, 2011.

. Novas tecnologias, novos textos, novas formas de pensar. 3. ed. Belo Horizonte: Autêntica, 2006.

DAHER, Andrea. A conversão do gentio ou a educação. In: VIDAL, Diana Gonçalves; HILSDORF, Maria Lúcia Spedo (Org.). Brasil 500 anos: tópicas em história da educação. 1. ed. São Paulo: Edusp, 2001. v. 1, p. 42-65.

. A oralidade perdida: ensaios de história das práticas letradas. Rio de Janeiro:

Civilização Brasileira, 2012.

. Escrita e conversão: a gramática tupi e os catecismos bilíngues no Brasil do século XVI. Revista Brasileira de Educação, n. 8, maio/jun./jul./ago. 1998.

DIAS, Anair Valenia Martins. Recepção e produção do gênero autobiografia mediadas por tecnologias digitais. 2013, 214 p. Tese (Doutorado em Linguística Aplicada em Linguagem e Tecnologias) - Universidade Estadual de Campinas, Campinas, 2013.

DOLZ, Joaquim; GAGNON, Roxane; DECÂNDIO, Fabrício. Produção escrita e dificuldades de aprendizagem. Adaptação de Joaquim Dolz e Fabrício Decândio. Tradução de Fabrício Decândio e Anna Raquel Machado. Campinas: Mercado de letras, 2010.

DOLZ, Joaquim; NOVERRAZ, Michele; SCHNEUWLY, Bernard. Sequências didáticas para o oral e a escrita: apresentação de um procedimento. In: SCHNEUWLY, Bernard; DOLZ, Joaquim. Gêneros orais e escritos na escola. Tradução e organização de Roxane Rojo e Glais Sales Cordeiro. Campinas: Mercado de Letras, 2004. p. 81-108.

DOLZ, Joaquim; SCHNEUWLY, Bernard. Gêneros e progressão em expressão oral e escrita: elementos para reflexões sobre uma experiência (francófona). In: SCHNEUWLY, Bernard; DOLZ, Joaquim. Gêneros orais e escritos na escola. Tradução e organização de Roxane Rojo e Glais Sales Cordeiro. Campinas: Mercado de Letras, 2004. p. 35-60. 
DUDENEY, Gavin; HOCKLY, Nicky; PEGRUM, Mark. Letramentos digitais. Tradução de Marcos Marciolino. 1. ed. São Paulo: Parábola Editorial, 2016.

DUTRA, André de Freitas. O Professor Orientador de Informática Educativa - POIE das escolas do município de São Paulo. 2010. 128 f. Dissertação (Mestrado em Educação) - Universidade de São Paulo, São Paulo, 2010.

FRADE, Isabel Cristina Alves da Silva. Alfabetização digital: problematização do conceito e possíveis relações com a pedagogia e com aprendizagem inicial do sistema de escrita. In: COSCARELLI, Carla Viana; RIBEIRO, Ana Elisa (Org.). Letramento digital: aspectos sociais e possibilidades pedagógicas. 3. ed. Belo Horizonte: Autêntica; Ceale/Fae/UFMG, 2011a. p. 59-83.

. Cultura escrita no final do século XIX e início do século XX em Minas Gerais: suportes, instrumentos e textos de alunos e professores. In: REUNIÃO ANUAL DA ANPED - CONSTITUIÇÃO BRASILEIRA, DIREITOS HUMANOS E EDUCAÇÃO, 31., Caxambu, Anais... Caxambu: 2008. p. 1-15.

. História da alfabetização e da cultura escrita: discutindo uma trajetória de pesquisa. In: MORTATTI, Maria do Rosário Longo (Org.). Alfabetização no Brasil: uma história de sua história. São Paulo: Cultura Acadêmica; Marília: Oficina Universitária, 2011b. p. 177-197.

. Métodos de alfabetização, métodos de ensino e conteúdos da alfabetização:

perspectivas históricas e desafios atuais. Educação (UFSM), v. 32, p. 21-40, 2007.

. Suportes, instrumentos e textos de alunos e professores em Minas Gerais: indicações sobre usos da cultura escrita nas escolas no final do século XIX e início do século XX. História da Educação, Pelotas, n. 29, p. 29-55, set./dez. 2009.

FRADE, Isabel Cristina da Silva; GALVAO, Ana Maria Oliveira. Instrumentos e suportes de escrita no processo de escolarização: entre os usos prescritos e os não convencionais (Minas Gerais, primeira meta de do século XX). Rev. Bras. Hist. Educ., Maringá, v. 16, n. 1 (40), p. 297-334, jan./abr. 2016.

GLÓRIA, Julianna Silva. A alfabetização e sua relação com o uso do computador: o suporte digital como mais um instrumento de alfabetização na escola. Texto Livre, Belo Horizonte, v. 5, n. 2, p. 61-71, 2012.

Influências e confluências do uso do suporte de escrita digital na alfabetização de crianças do 10 ano do primeiro ciclo. Tese (Doutorado em Educação) - Universidade Federal de Minas Gerais, Minas Gerais, 2011.

GLÓRIA, Julianna Silva; FRADE, Isabel Cristina Alves da Silva. A alfabetização e sua relação com o uso do computador: o suporte digital como mais um instrumento de ensino-aprendizagem da escrita. Educação em Revista, Belo Horizonte, v. 31, n. 3, p. 339-358, jul./set. 2015. 
GÓES, Maria Cecília Rafael de. A abordagem microgenética na matriz histórico-cultural: uma perspectiva para o estudo da constituição da subjetividade. Cad. Cedes, Campinas, v. 20, n. 50, p. 9-25, abr. 2000.

. A criança e a escrita reflexiva: explorando a dimensão reflexiva do ato de escrever. In: SMOLKA, Ana Luisa; GÓES, Maria Cecília Rafael de (Org.). A linguagem e o outro no espaço escolar: Vygotsky e a construção do conhecimento. Campinas: Papirus, 1993. p. 99-118.

GOMES-SANTOS, Sandoval Nonato; JORDÃO, Heloisa Gonçalves. Interação e trabalho docente em aula de alfabetização. Trabalhos em Linguística Aplicada, Campinas, v. 53, p. 33-54, 2014.

GOMÉZ, Antonio Castillo. Historia de la cultura escrita: ideas para el debate. Revista Brasileira de História da Educação, n. 5, p. 93-124, jan./jun. 2003.

HANSEN, João Adolfo. A civilização pela palavra. In: LOPES, Eliane Marta Teixeira; FARIA FILHO, Luciano Mendes; VEIGA, Cynthia Greive (Org.). 500 anos de educação no Brasil. 2. ed. Belo Horizonte: Autêntica, 2000. v. 1, p. 19-41.

. Ratio Studiorum e política católica ibérica no século XVII. In: VIDAL, Diana Gonçalves; HILSDORF, Maria Lúcia Spedo (Org.). Brasil 500 anos: tópicas em história da educação. 1. ed. São Paulo: Edusp, 2001. v. 1, p. 13-41.

HÉBRARD, Jean. Por uma bibliografia material das escritas or dinárias: o espaço gráfico do caderno escolar (França - séculos XIX e XX). Revista Brasileira de História da Educação, Campinas: Editora Autores Associados/SBHE, n. 1, p. 115-141, jan./jun. 2001.

HILSDORF, Maria Lúcia Spedo. Cultura escolar / cultura oral em São Paulo (1820-1860). In: VIDAL, Diana Gonçalves; HILSDORF, Maria Lúcia Spedo (Org.). Brasil 500 anos: tópicas em história da educação. 1. ed. São Paulo: Edusp, 2001. v. 1, p. 67-96.

JOLIBERT, Josette. Formando crianças produtoras de textos. Tradução de Walkiria M. F. Settineri e Bruno Charles Magne. Porto Alegre: Artes Médicas, 1994.

JORDÃO, Heloisa Gonçalves. Grupos heterogêneos em período de alfabetização no 3o ano do Ensino Fundamental - percalços e soluções. Revista Melp, v. 6, p. 1, 2011.

. Interação e linguagem em sala de aula: entre o didático e o institucional. In:

GONÇALVES-SEGUNDO, P. R.; MODOLO, A. D. R.; SOUSA, D. R. de; FERREIRA, F. M.; COAN, G. I.; BRITTO-COSTA, L. F. (Org.). Texto, discurso e multimodalidade: perspectivas atuais. 1. ed. São Paulo: Editora Paulistana, 2017. v. 1, p. 213-228. 
O trabalho com regras de jogos e brincadeiras em classes de alfabetização - ler, aprender, brincar. Revista Melp, v. 7, p. 1, 2013.

JORDÃO, Heloisa Gonçalves; NONATO, Sandoval. Forma escolar, trabalho docente e produção textual: novas configurações. Diálogo das Letras, Pau dos Ferros, v. 7, n. 3, p. 208-227, set./dez. 2018.

JULIA, Dominique. A cultura escolar como objeto histórico. Revista Brasileira de História da Educação, n. 1, p. 9-44, 2001.

KAUFMAN, Ana Maria; RODRIGUEZ, Maria Elena. Escola, leitura e produção de textos. Porto Alegre: Artmed, 1995.

KENSKI, Vani Moreira. Educação e tecnologias: o novo ritmo da informação. Campinas: Papiros, 2007.

Novas Tecnologias: o redimensionamento do espaço e os impactos do trabalho docente. Revista Brasileira de Educação, n. 8, maio/jun./jul./ago. 1998.

LEAL, Telma Ferraz; LUZ, Patrícia Santos. Produção de textos narrativos em pares: reflexões sobre o processo de interação. Educação e Pesquisa, São Paulo, v. 27, n. 1, p. 27-45, jan./jun. 2001.

LOPES, R. Deus et al. Estudos e Pesquisas Educacionais. O uso dos computadores e da internet em escolas públicas de capitais brasileiras. Relatório final. São Paulo: Fundação Vitor Civita, v. 1, 2010. p. 275-335.

LUIZE, Andrea. O processo de apropriação da escrita na infância: situações interativas na produção textual. 2007. 196 f. Dissertação (Mestrado em Educação) - Universidade de São Paulo, São Paulo, 2007.

MARCUSCHI, Luiz Antônio. A questão do suporte dos gêneros textuais. DLCV: Língua, Linguística e Literatura, João Pessoa, v. 1, n. 1, p. 9-40, out. 2003.

. Linearização, cognição e referência: o desafio do hipertexto. Línguas e Instrumentos Lingüísticos, Campinas, v. 3, p. 21-46, 1999.

. O hipertexto como um novo espaço de escrita em sala de aula. Linguagem \& Ensino, Pelotas, v. 4, n. 1, p. 79-112, 2001.

MARINELLO, Adiane Fogali; BOFF, Odete Maria Benetti; KOCHE, Vanilda Salton. O texto instrucional como um gênero textual. The ESPecialist, v. 29, n. especial, p. 61-77, 2008. 
MOLINARI, Claudia; FERREIRO, Emilia. Identidades e diferenças na escrita em papel e em computador nas primeiras etapas do processo de alfabetização. In: $\mathbf{O}$ ingresso na escrita e nas culturas do escrito. São Paulo: Cortez, 2013. p. 77-100.

MORAIS, Artur Gomes de. Ortografia: este peculiar objeto de conhecimento. In: MORAIS, Artur Gomes (Org.). O aprendizado da ortografia. 3. ed. Belo Horizonte: Autêntica, 2002.

MORTATTI, Maria do Rosário Longo. Educação e letramento. São Paulo: Unesp, 2004.

PIETRI, Emerson de. A constituição da escrita escolar em objeto de análise dos estudos linguísticos. Trabalhos em Linguística Aplicada, Campinas, v. 46, n. 2, p. 283-297, 2007.

PINHEIRO, Petrilson Alan. Práticas colaborativas de escrita por meio de ferramentas da internet: ressignificando a produção textual na escola. 2011. 247 p. Tese (Doutorado em Linguística Aplicada) - Universidade Estadual de Campinas, Campinas, 2011.

PRETI, Dino. Análise de textos orais. 6. ed. São Paulo: Humanitas Publicações FFLCH/USP, 2003.

RAZZINI, Márcia de Paula Gregório. Instrumentos de escrita na escola elementar: tecnologias e práticas. In: MIGNOT, Ana Chrystina Venâncio (Org.). Cadernos à vista: escola, memória e cultura escrita. Rio de Janeiro: Eduerj, 2008. p. 91-114.

RIBEIRO, Ana Elisa. Tecnologia digital e ensino: breve histórico e seis elementos para a ação. Linguagem \& Ensino, Pelotas, v. 19, n. 2, p. 91-111, jul./dez. 2016 a.

. Textos multimodais: leitura e produção. 1. ed. São Paulo: Parábola Editorial, 2016b.

ROJO, Roxane Helena Rodrigues. Entre plataformas, Odas e protótipos: novos multiletramentos em tempos de Web2. The ESPecialist: Descrição, Ensino e Aprendizagem, v. 38, n. 1, jan./jul. 2017.

- Revisitando a produção de textos na escola. In: VAL, Maria da Graça Costa; ROCHA Gladys (Org.). Reflexões sobre práticas escolares de produção de textos. Belo Horizonte: Autêntica; Ceale/Fae/UFMG, 2008.

ROJO, Roxane Helena Rodrigues; MOURA, Eduardo (Org.). Multiletramentos na escola. São Paulo: Parábola, 2012.

SANTOS, Verônica Gomes dos; ALMEIDA, Sandra Estefânia de; ZANOTELLO, Marcelo. A sala de aula como ambiente equipado tecnologicamente: reflexões sobre formação docente, ensino e aprendizagem nas séries iniciais da educação básica. Em. Bras. Estud. Pedagog., Brasília, v. 99, n. 252, p. 331-349, maio/ago. 2018. 
SÃO PAULO. Secretaria Municipal de Educação. Diretoria de Orientação Técnica. Programa Mais Educação: subsídios para a implantação. São Paulo, 2014. 116 p.

SEABRA, Carlos. O computador na criação de ambientes interativos de aprendizagem. Em Aberto, Brasília, ano 12, n. 57, jan./mar. 1993.

SMOLKA, Ana Luiza Bustamante. A criança na fase inicial da escrita: a alfabetização como processo discursivo. 10. ed. São Paulo: Cortez; Campinas: Editora da Universidade Estadual de Campinas, 2001. (Coleção Passando a Limpo).

SOARES, Magda Becker. Alfabetização: a questão dos métodos. São Paulo: Contexto, 2016. 2003. . A reinvenção da alfabetização. Presença Pedagógica, v. 9, n. 52, p. 14-21, jul./ago. fev. 1985.

As muitas facetas da alfabetização. Cadernos de Pesquisa, São Paulo, n. 52, p. 19-24, . Letramento: um tema em três gêneros. 2. ed. Belo Horizonte: Autêntica; Ceale/Fae/UFMG 2001.

. Novas práticas de letramento na cibercultura. Educação e Sociedade, Campinas, v. 23, n. 81, p. 143-160, dez. 2002.

TANCK DE ESTRADA, Dorothy. Innovacion en la ensenanza de la lectura en el México Independiente, 1821-1840. Nueva Revista de Filología Hispánica, XXXVIII, n. 1, p. 141-162, 1990.

. La enseñanza de la lectura y la escritura en la Nueva España: 1700-1821. In: Historia de la lectura em México. México: Colegio de México, 1988. p. 49-93.

TAVARES, Clara Ferrão; BARBEIRO, Luís Filipe. As implicações das TIC no ensino da língua. Lisboa: Ministério da Educação, Direcção-Geral de Inovação e Desenvolvimento Curricular, 2011.

TEBEROSKY, Ana. Alfabetização e tecnologia da informação e comunicação (TIC). In: TEBEROSKY, Ana; GALLART, M. S. (Org.). Contextos de alfabetização inicial. Porto Alegre: Artmed, 2004. p. 153-164.

. Para que aprender a escrever? In: TEBEROSKY, Ana; TOLCHINSKY, Liliana (Org.). Além da alfabetização: a aprendizagem fonológica, ortográfica, textual e matemática. São Paulo: Editora Ática, 2002. p. 19-36. 
TOZONI-REIS, Marília Freitas de Campos. Metodologia de pesquisa. 2. ed. Curitiba: lesde Brasil S.A., 2009.

TRAVAGLIA, Luiz Carlos. Um estudo textual-discursivo do verbo no português do Brasil. 1991. 470 p. Tese (Doutorado em Linguística) - Universidade Estadual de Campinas, Campinas, 1991.

TRIPP, David. Pesquisa-ação: uma introdução metodológica. Educação e Pesquisa, São Paulo, v. 31, n. 3, p. 443-466, set./dez. 2005. Tradução de Lólio Lourenço de Oliveira.

TRUCANO, M. Knowledge maps: ICT in education. What do we know about the effective uses of information and communication technology in education in developing countries? Washington: infoDev/World Bank, 2005. Disponível em: http://www.infodev.org/en/Publication.8.html. Acesso em: 18 jan. 2015.

VAL, Maria da Graça Costa; BARROS, Lúcia Fernanda Pinheiro Barros. Receitas e regras de jogo: a construção de textos injuntivos por crianças em fase de alfabetização. In: VAL, Maria da Graça Costa; ROCHA, Gladys (Org.). Reflexões sobre práticas escolares de produção de texto: o sujeito autor. Belo Horizonte: Autêntica; Ceale/Fae/UFMG, 2008. p. 135-166.

VARELA, Júlia; ALVAREZ-URIA, Fernando. A maquinaria escolar. Teoria e Educação, Porto Alegre: Pannonica, n. 6, p. 68-96, 1992.

VIDAL, Diana Gonçalves. No interior da sala de aula: ensaio sobre cultura e prática escolares. Currículo sem Fronteiras, v. 9, n. 1, p. 25-41, jan./jun. 2009. ISSN 1645-1384.

. Prefácio: Em que os estudos de natureza histórica podem contribuir com as práticas de alfabetização na atualidade? In: MORTATTI, Maria do Rosário Longo; FRADE, Isabel Cristina Alves da Silva (Org.). História do ensino de leitura e escrita: métodos e material didático. São Paulo: Editora Unesp; Marília: Oficina Universitária, 2014.

VIDAL, Diana; GVIRTZ, Silvina. O ensino da escrita e a conformação da modernidade escolar: Brasil e Argentina, 1880-1940. Revista Brasileira de Educação, n. 8, p. 13-30, maio/jun./jul./ago. 1998.

VILLALTA, Luiz Carlos. A educação na colônia e os jesuítas: discutindo alguns mitos. In: PRADO, Maria Lígia Coelho; VIDAL, Diana Gonçalves (Org.). À margem dos 500 anos: reflexões irreverentes. São Paulo: Edusp, 2002. p. 171-184.

VILLELA, Heloisa de O. S. O mestre-escola e a professora. In: LOPES, Eliane Marta Teixeira; FARIA FILHO, Luciano Mendes; VEIGA, Cynthia Greive (Org.). 500 anos de educação no Brasil. 1. ed. Belo Horizonte: Autêntica, 2007. v. 1. 
VINCENT, Guy; LAHIRE, Bernard; THIN, Daniel. Sobre a história e a teoria da forma escolar. Educação em Revista, Belo Horizonte, n. 33, p. 7-47, jun. 2001.

WITTMANN, Reinhard. Existe uma revolução da leitura no final do século XVIII? In: CAVALLO, Guglielmo; CHARTIER, Roger (Org.). História da leitura no mundo ocidental. São Paulo: Ática, 1998. p. 135-163. 


\title{
ANEXO A - CURRÍCULO DE LÍNGUA PORTUGUESA PARA OS $3^{\text {os }}$ ANOS. DOCUMENTO RECOLHIDO EM CAMPO
}

\author{
$1^{\mathrm{a}}$ VERSÃO DO CURRÍCULO DEFINIDO EM 2016 ( $1^{\circ}$ ao $5^{\circ}$ \\ ANO) - APLICAÇÃO EM 2017
}

\section{CURRÍCULO ELENCADO - LÍNGUA PORTUGUESA}

DIREITOS DE APRENDIZAGEM:

$3^{\circ}$ ANO: Compreender e produzir textos orais de diferentes gêneros. Produzir textos escritos de gêneros específicos. Trabalho com outros gêneros envolvendo algumas personagens já conhecidas pelas crianças (múltiplos sentidos do leitor). Compreender alguns textos do cotidiano escolar. Participar de situações de escuta e produção oral e de pequenos textos escritos envolvendo temas sociais relevantes/preconceito racial, de gênero e linguístico.

COMBINADOS PARA A ROTINA:

ATIVIDADE DE LEITURA DUAS VEZES NA SEMANA: $3^{\text {os }}$ ANOS OBS.: ESSAS ATIVIDADES CONSISTEM EM DIFERENTES DINÂMICAS A SEREM USADAS PELOS PROFESSORES, UMA DE CADA VEZ, QUE ENVOLVEM MOMENTOS DE LEITURA NA SALA. SEGUEM ABAIXO ALGUMAS POSSIBILIDADES:

- O PROFESSOR OFERECE DIFERENTES LIVROS PARA OS ALUNOS MANUSEAREM. DEMOCRATICAMENTE, A TURMA ESCOLHE UM PARA SER LIDO PARA A TURMA. ESSA LEITURA PODE SER REALIZADA POR UM ALUNO (NÃO DEVE SER SEMPRE O MESMO) OU PELO PROFESSOR;

- O PROFESSOR, JUNTO COM A TURMA, DEFINE UM LIVRO VOLUMOSO, QUE SERÁ LIDO EM CAPÍTULOS AO LONGO DE UM PERÍODO (SEMANAS, MESES, BIMESTRE ETC.) PELO PROFESSOR OU POR UM ALUNO (NÃO DEVE SER SEMPRE O MESMO);

- O PROFESSOR OFERECE DIFERENTES LIVROS PARA OS ALUNOS MANUSEAREM. CADA UM REALIZA A LEITURA SILENCIOSA DO LIVRO E O PROFESSOR REALIZA UM MOMENTO DE TROCA DESSAS LEITURAS ENTRE A TURMA.

LEMBRAR A IMPORTÂNCIA DE MOMENTOS CONTEXTUALIZADOS DE LEITURA EM VOZ ALTA PREVISTOS NA ROTINA DA TURMA. 
$3^{\circ}$ ANO

TRABALHO COM OS SEGUINTES GÊNEROS DO DISCURSO: BILHETE, RECEITA, REGRAS DE JOGO, VERBETE DE DICIONÁRIO E NOTÍCIA.

\section{HABILIDADES:}

- escrever o nome completo;

- reconhecer e nomear as letras do alfabeto;

- aprofundar a ordem alfabética;

- organização das palavras em ordem alfabética (uso do dicionário);

- compreender que palavras diferentes compartilham as mesmas letras;

- segmentar oralmente as sílabas de palavras e comparar as palavras quanto ao tamanho;

- identificar semelhanças sonoras em sílabas e rimas;

- ler palavras e textos, ajustando a pausa sonora ao escrito;

- leitura e interpretação de texto não verbal (base para produção de pequenas interpretações escritas individuais);

- compreender textos lidos por outras pessoas;

- antecipar sentido e ativar conhecimentos prévios;

- localizar informações explícitas no texto lido por alguém ou autonomamente;

- realizar inferências em texto lido por alguém ou autonomamente;

- estabelecer relações lógicas entre partes de textos lidos por alguém ou autonomamente;

- apreender assuntos/temas tratados em textos lidos por alguém ou autonomamente;

- interpretar frases e expressões em textos lidos por alguém ou autonomamente;

- leitura lúdica: trava-língua;

- leitura compartilhada de textos;

- reescrita de texto individualmente, em dupla e coletivamente;

- planejar intervenções orais em situações públicas: exposição oral, debate ou contação de história;

- pontuação: trabalho com ponto final, travessão, interrogação, exclamação e vírgula (aprofundamento); caso não tenha existido tempo hábil no $2^{\circ}$ ano, introduzir os dois pontos;

- letra bastão maiúscula e minúscula (caixa alta e baixa).

FALTA DEFINIR REGRAS DE ESCRITA (P/B, T/D, F/V, S/SS/C/C/X, R/RR ETC.) E DE ACENTUAC $\tilde{O} O$ PARA CADA ANO. 


\title{
ANEXO B - TERMO DE CONSENTIMENTO LIVRE E ESCLARECIDO
}

\author{
TERMO DE CONSENTIMENTO LIVRE E ESCLARECIDO
}

Eu, João Eduardo Cruz da Silva, compreendo os direitos dos participantes desta pesquisa intitulada "Reformulações e gestos didáticos no ensino da lingua escrita", orientada por Sandoval Nonato Gomes Santos, professor da Faculdade de Educação da Universidade de Săo Paulo e que tem como pesquisadora responsável Heloisa Gonçalves Jordão, aluna do programa de pós graduação na mesma instituição, que podem ser contatados pelos emails sandovalnotato@usp.br e heloisa.jordao@usp.br ou pelo telefone 11-982253201. Autorizo a participação destes pesquisadores na qualidade de responsável por esta instituição. Compreendo como e porquê este estudo está sendo realizado. Os responsáveis pela pesquisa garantem o sigilo que assegura a privacidade dos sujeitos quanto aos dados envolvidos na pesquisa. Receberei uma cópia assinada deste formulário de consentimento.

São Paulo, 10 de agosto de 2016

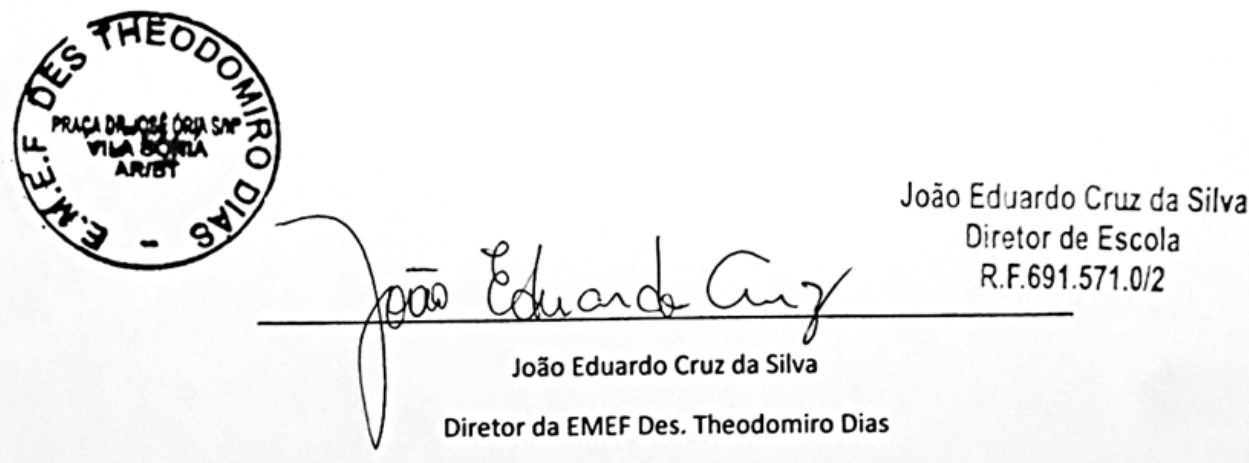


ANEXO C - MAPEAMENTOS

\begin{tabular}{|l|l|l|}
\hline SEQUÊNCIA DIDÁTICA: RJ & Turma: 3o A & ATIVIDADE: 1- Produção escrita inicial \\
\hline Pesquisadora: Heloisa Jordão & Professora colaboradora: C. \\
\hline Ambiente: Lab. Info & Total de gravação: \\
\hline Data:30' \\
\hline
\end{tabular}

Mapeamento:

\begin{tabular}{|c|c|c|c|c|c|c|}
\hline Cam & \multirow{2}{*}{$\begin{array}{l}\text { Etapas do } \\
\text { EVENTO aula }\end{array}$} & \multirow{2}{*}{$\begin{array}{l}\text { TEMPO } \\
\text { min'seg" } \\
\text { Arquivo }\end{array}$} & \multicolumn{3}{|c|}{ Elementos interacionais } & \multirow{2}{*}{ RESUMO NARRATIVIZADO } \\
\hline 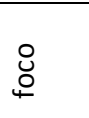 & & & OBJETO DE ENSINO & INSTRUMENTO DIDÁTICO & $\begin{array}{l}\text { FORMAS } \\
\text { SOCIAIS DE } \\
\text { TRABALHO }\end{array}$ & \\
\hline$\overline{\frac{\pi}{d}}$ & $\begin{array}{l}\text { Abertura: } \\
\text { - Chamada } \\
\text { Preparação: } \\
\text { - Comanda/ } \\
\text { consigna }\end{array}$ & $\begin{array}{l}0^{\prime} 30^{\prime \prime} \text { até } \\
60^{\prime \prime}\end{array}$ & $\begin{array}{l}\text {-Textualização: } \\
\text { Reprodução escrita de } \\
\text { regra de jogo } \\
\text { conhecida de memória }\end{array}$ & $\begin{array}{l}\text { - Instrução oral } \\
\text { - teclas bloqueadas } \\
\text { - instrução escrita; }\end{array}$ & M & $\begin{array}{l}\text { Retoma a aula anterior, apresenta a consigna escrita para os alunos e pede que } \\
\text { dois alunos leiam em voz alta. } \\
\text { Contextualiza o texto 'regra de jogo': proposta é que cada dupla redija o texto } \\
\text { conhecido de memória para definirem regras únicas para o desenvolvimento de } \\
\text { um campeonato. }\end{array}$ \\
\hline 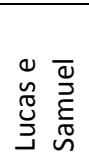 & Desenvolvimento & $\begin{array}{l}09^{\prime} 55^{\prime \prime} \text { até } \\
14^{\prime} 30^{\prime \prime}\end{array}$ & $\begin{array}{l}\text { - Textualização } \\
\text { - Revisão } \\
\text { - Concordância verbal }\end{array}$ & $\begin{array}{l}\text { - Editor de texto (WORD) } \\
\text { - Teclado QWERT }\end{array}$ & D & $\begin{array}{l}\text { Ao realizar a leitura em voz alta os alunos observam um problema de } \\
\text { concordância verbal, do infinitivo para o gerúndio (Bater-batendo) }\end{array}$ \\
\hline
\end{tabular}




\begin{tabular}{|c|c|}
\hline SEQUÊNCIA DIDÁTICA: RJ_C & ATIVIDADE: 1 PRODUÇÃO ESCRITA INICIAL \\
\hline \multicolumn{2}{|l|}{ Turma: 3 ano C } \\
\hline Pesquisadora: Heloisa Jordão & Professora colaboradora: E. \\
\hline Ambiente: Lab Info & Total de gravação: 35’ 43"' \\
\hline Mídia: 3C_300816 & Total a ser transcrito: $16^{\prime} 52^{\prime \prime}$ até $35^{\prime} 00^{\prime \prime}$ \\
\hline
\end{tabular}

\begin{tabular}{|c|c|c|c|c|c|c|}
\hline \multicolumn{7}{|c|}{ Mapeamento: } \\
\hline $\mathrm{Ca}$ & \multirow{2}{*}{$\begin{array}{l}\text { EVENTO } \\
\text { Tarefas }\end{array}$} & \multirow{2}{*}{$\begin{array}{l}\text { TEMPO } \\
\text { min'seg" } \\
\text { Arquivo }\end{array}$} & \multicolumn{3}{|c|}{ Elementos didáticos } & \multirow[t]{2}{*}{ RESUMO NARRATIVIZADO } \\
\hline $\begin{array}{l}\text { ठ } \\
\text { ¿ }\end{array}$ & & & OBJETO DE ENSINO & $\begin{array}{l}\text { INSTRUMENTO } \\
\text { DIDÁTICO }\end{array}$ & $\begin{array}{l}\text { Forma } \\
\text { Social } \\
\text { Trab. }\end{array}$ & \\
\hline $\begin{array}{l}\overline{\widetilde{0}} \\
\bar{\Xi}\end{array}$ & Preparação & $\begin{array}{l}05^{\prime} 51^{\prime \prime}- \\
11^{\prime} 43^{\prime \prime}\end{array}$ & $\begin{array}{l}\text { - Produção escrita; } \\
\text { - Uso da letra } \\
\text { maiúscula } \\
\text { - Tec: uso das teclas } \\
\text { shift, caps lock. }\end{array}$ & $\begin{array}{l}\text { - Instrução oral } \\
\text { - teclas bloqueadas } \\
\text { - instrução escrita; } \\
\text { - Editor de texto } \\
\text { (WORD) } \\
\text { - Teclado QWERT }\end{array}$ & $\begin{array}{l}\mathrm{M} \\
\mathrm{Q}\end{array}$ & $\begin{array}{l}\text { Professora expõe uma situação comunicativa fictícia(todos podem } \\
\text { acompanhar na tela de seus computadores). Professora explica para } \\
\text { todos questões relacionadas ao uso de letra maiúscula e como realizar } \\
\text { essa marcação por meio do teclado. }\end{array}$ \\
\hline $\begin{array}{l}\overline{\widetilde{J}} \\
\bar{\Xi}\end{array}$ & $\begin{array}{l}\text { Desenvolvime } \\
\text { nto }\end{array}$ & $\begin{array}{l}11^{\prime} 50^{\prime \prime} \\
16^{\prime} 50^{\prime}\end{array}$ & $\begin{array}{l}\text { - Uso da letra } \\
\text { maiúscula; } \\
\text { - Produção escrita }\end{array}$ & $\begin{array}{l}\text { - Editor de texto } \\
\text { (WORD) } \\
\text { - Teclado QWERT }\end{array}$ & D & $\begin{array}{l}\text { Professoras circulam pelas duplas orientando os alunos em relação ao uso } \\
\text { da letra maiúscula. }\end{array}$ \\
\hline$\frac{\frac{\pi}{2}}{\frac{2}{0}}$ & $\begin{array}{l}\text { Desenvolvime } \\
\text { nto } \\
\text { Matheus/ } \\
\text { Emily }\end{array}$ & $\begin{array}{l}17^{\prime} 50^{\prime \prime} \\
18^{\prime} 40^{\prime \prime}\end{array}$ & $\begin{array}{l}\text { - produção escrita } \\
\text { - Coerência e } \\
\text { ortografia }\end{array}$ & $\begin{array}{l}\text { - Editor de texto } \\
\text { (WORD) } \\
\text { - Teclado QWERT }\end{array}$ & $\mathrm{D}$ & $\begin{array}{l}\text { Aluna se coloca como incapaz de realizar a produção. Prof. reformula a } \\
\text { instrução e regula a participação da dupla (o aluno que domina melhor o } \\
\text { jogo se preocupa com a composição e o que domina menos se atém a } \\
\text { questões de ortografia e de coerência). }\end{array}$ \\
\hline
\end{tabular}




\begin{tabular}{|c|c|c|l|l|l|l|}
\hline & $\begin{array}{c}\text { Desenvolvime } \\
\text { nto } \\
\text { Lucas e } \\
\text { Raissa }\end{array}$ & $22^{\prime} 10^{\prime \prime}$ & $\begin{array}{l}\text { - Produção escrita } \\
\text {-SEA } \\
\text { - Uso da tecla enter } \\
\text { - Segmentação } \\
\text { - Planificação }\end{array}$ & $\begin{array}{l}\text { - Editor de texto } \\
\text { (WORD) } \\
\text { - Teclado QWERT }\end{array}$ & D & $\begin{array}{l}\text { Acompanhamento da produção de alunos com dificuldades na produção } \\
\text { escrita. }\end{array}$ \\
\hline
\end{tabular}

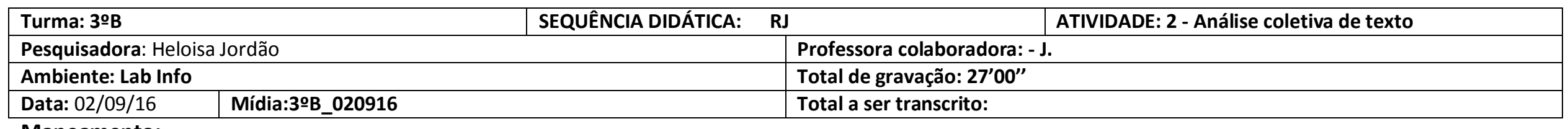

\section{Mapeamento:}

\begin{tabular}{|c|c|c|c|c|c|c|}
\hline Cam & \multirow{2}{*}{$\begin{array}{l}\text { EVENTO } \\
\text { Tarefas }\end{array}$} & \multirow{2}{*}{$\begin{array}{l}\text { TEMPO } \\
\text { min'seg" } \\
\text { Arquivo }\end{array}$} & \multicolumn{3}{|c|}{ Elementos didáticos } & \multirow[t]{2}{*}{ RESUMO NARRATIVIZADO } \\
\hline$\stackrel{8}{\circ}$ & & & OBJETO DE ENSINO & $\begin{array}{l}\text { INSTRUMENTO } \\
\text { DIDÁTICO }\end{array}$ & $\begin{array}{l}\text { Formas } \\
\text { Sociais } \\
\text { Trabalho }\end{array}$ & \\
\hline 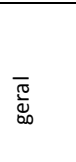 & $\begin{array}{l}\text { Retomada da } \\
\text { situação } \\
\text { comunicativa. }\end{array}$ & $\begin{array}{l}O^{\prime} 28^{\prime \prime} \\
2^{\prime} 30^{\prime \prime}\end{array}$ & - Produção escrita & $\begin{array}{l}\text { - Telas bloqueadas; } \\
\text { - Instrução oral }\end{array}$ & M & $\begin{array}{l}\text { A professora rememora a situação comunicativa e acresce a proposta da } \\
\text { realização de um campeonato. Observa que, em uma primeira leitura das regras } \\
\text { escritas pelos alunos, há muita diferença nos textos e para que um campeonato } \\
\text { ocorra eles precisarão trabalhar no desenvolvimento de uma regra única. }\end{array}$ \\
\hline 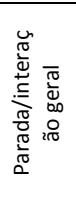 & $\begin{array}{l}\text { Revisão de } \\
\text { texto } \\
\text { produzido por } \\
\text { colegas }\end{array}$ & $\begin{array}{l}2^{\prime} 30^{\prime \prime} \\
08^{\prime} 11^{\prime \prime}\end{array}$ & $\begin{array}{l}\text { - Produção escrita } \\
\text { - coerência textual; } \\
\text { - Tec: abrir pastas e } \\
\text { documentos. }\end{array}$ & $\begin{array}{l}\text {-Instrução oral (geral) } \\
\text {-Texto projetado nos } \\
\text { computadores; } \\
\text { - Leitura feita por } \\
\text { aluno. }\end{array}$ & $Q$ & $\begin{array}{l}\text { A professora solicita que alguma dupla compartilhe a produção de texto } \\
\text { desenvolvida na aula anterior. Uma dupla consente (Miguel e Gabriel Moreira). } \\
\text { A professora solicita a leitura e problematiza pontos do texto mais ligados a } \\
\text { composição e estrutura e não toca em aspectos ortográficos. Na sequência } \\
\text { convida os alunos a terem o mesmo olhar para seus próprios textos. }\end{array}$ \\
\hline $\begin{array}{l}\frac{\pi}{0} \\
\frac{\pi}{\pi} \frac{\pi}{2} \\
\frac{\pi}{0}\end{array}$ & $\begin{array}{l}\text { Trabalho } \\
\text { Bruna e } \\
\text { Vinicius } \\
\text { Herculano }\end{array}$ & $\begin{array}{l}08^{\prime} 20^{\prime \prime} \\
18^{\prime} 31^{\prime \prime}\end{array}$ & $\begin{array}{l}\text { - Leitura } \\
\text { - Coerência } \\
\text { - Produção escrita } \\
\text {-referente/Significado } \\
\text { - Segmentação } \\
\text { - Estrutura alfabética }\end{array}$ & $\begin{array}{l}\text {-Instrução oral (para a } \\
\text { dupla) } \\
\text {-Editor de texto; } \\
\text { - Teclado qwert }\end{array}$ & D & $\begin{array}{l}\text { Alunos revisam o texto que já escreveram, reformulando alguns pontos } \\
\text { conforme a comanda da atividade. Resolvidas algumas questões eles continuam } \\
\text { a redigir o texto: } \\
\text { Surgem questões relacionadas à segmentação e a ortografia, objeto de debate } \\
\text { entre os alunos, já questões de coerência surgem mas não fomenta o debate. } \\
\text { Problema do referente }\left(18^{\prime}\right) \text { "' brincs". }\end{array}$ \\
\hline
\end{tabular}




\begin{tabular}{|c|c|c|c|c|c|c|}
\hline 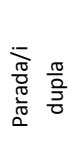 & $\begin{array}{l}\text { Trabalho de } \\
\text { Olívia e } \\
\text { Thamires }\end{array}$ & $\begin{array}{l}20^{\prime} 00^{\prime} \\
25^{\prime} 50^{\prime \prime}\end{array}$ & $\begin{array}{l}\text { - referência } \\
\text {-coerência }\end{array}$ & $\begin{array}{l}\text {-Editor de texto; } \\
\text { - Teclado qwert }\end{array}$ & $D$ & $\begin{array}{l}\text { Ao realizar a leitura do que já fora produzido a professora realiza uma efetiva } \\
\text { pergunta acerca do vocábulo 'escalar' e os alunos entram em reflexões sobre o } \\
\text { uso que o termo ganha no contexto do jogo. Alunas planejam o texto oralmente } \\
\text { para depois redigir. }\end{array}$ \\
\hline 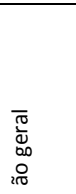 & $\begin{array}{l}\text { Encerramento } \\
\text { da aula }\end{array}$ & $25^{\prime} 51^{\prime \prime}$ & $\begin{array}{l}\text { - Tec: salvar documentos } \\
\text { - Tec: Área de trabalho }\end{array}$ & $\begin{array}{l}\text { - Instruções passo-a- } \\
\text { passo }\end{array}$ & $M$ & $\begin{array}{l}\text { Professora solicita que um aluno auxilie no encerramento da aula salvando os } \\
\text { documentos. Dá os procedimentos de encerramento da aula }\end{array}$ \\
\hline
\end{tabular}

\begin{tabular}{|l|l|l|}
\hline Turma: 3o C & SEQUÊNCIA DIDÁTICA: RJ & ATIVIDADE: 2 -Análise coletiva de texto \\
\hline Pesquisadora: Heloisa Jordão & Professora colaboradora: E. \\
\hline Ambiente: Lab. Info. & Total de gravação: 31'00”' \\
\hline Data: 02/09/16 (SEX) & Mídia: 3C_020916 & Total a ser transcrito: 13'40" até 28”' \\
\hline
\end{tabular}

\section{Mapeamento:}

\begin{tabular}{|c|c|c|c|c|c|c|}
\hline Cam & \multirow{2}{*}{$\begin{array}{l}\text { EVENTO } \\
\text { Tarefas }\end{array}$} & \multirow{2}{*}{$\begin{array}{l}\text { TEMPO } \\
\text { min'seg" } \\
\text { Arquivo }\end{array}$} & \multicolumn{3}{|c|}{ Elementos didáticos } & RESUMO NARRATIVIZADO \\
\hline$\stackrel{8}{\circlearrowright}$ & & & $\begin{array}{l}\text { OBJETO DE } \\
\text { ENSINO }\end{array}$ & INSTRUMENTO DIDÁTICO & $\begin{array}{c}\text { FORMAS } \\
\text { SOCIAIS } \\
\text { TRABALHO }\end{array}$ & \\
\hline$\overline{\widetilde{J}}$ & $\begin{array}{l}\text { Abertura da } \\
\text { atividade }\end{array}$ & $\begin{array}{l}00^{\prime} 00^{\prime \prime} \\
3^{\prime} 00^{\prime}\end{array}$ & $\begin{array}{l}\text { - produção de } \\
\text { texto } \\
\text {-revisão }\end{array}$ & - telas bloqueadas & Q & $\begin{array}{l}\text { Prof pergunta quem já finalizou a escrita. } O \text { aluno Matheus diz que a sua regra já está } \\
\text { terminada. "Ela está pronta para ser testada? Quem trouxe cards?" }\end{array}$ \\
\hline$\overline{\frac{\pi}{0}}$ & $\begin{array}{l}\text { Revisão } \\
\text { coletiva de } \\
\text { texto }\end{array}$ & $\begin{array}{l}3 \prime 00^{\prime \prime} \\
10^{\prime} 00^{\prime \prime}\end{array}$ & $\begin{array}{l}\text { - Produção } \\
\text { escrita } \\
\text { - leitura }\end{array}$ & $\begin{array}{l}\text { - Projeção do texto escrito } \\
\text { por um colega na tela dos } \\
\text { computadores das duplas }\end{array}$ & Q & $\begin{array}{l}\text { Solicita leitura silenciosa de todas as duplas; em seguida solicita que uma aluna realize } \\
\text { a leitura em voz alta. Dirigindo a atenção a elementos típicos do gênero RJ, a } \\
\text { professora problematiza aspectos positivos e negativos. }\end{array}$ \\
\hline$\frac{\frac{\pi}{2}}{\frac{2}{2}}$ & $\begin{array}{l}\text { Luiz Felipe } \\
\text { Keyla }\end{array}$ & $\begin{array}{l}13^{\prime} 40^{\prime \prime} \\
18^{\prime} 00^{\prime \prime}\end{array}$ & $\begin{array}{l}\text { - Revisão de texto } \\
\text { - Uso da conj. } \\
\text { OU/uso vírgula }\end{array}$ & $\begin{array}{l}\text {-teclado } \\
\text {-editor de texto }\end{array}$ & D & $\begin{array}{l}\text { Início da atividade de revisão em dupla. Na comanda a prof chama atenção tanto a } \\
\text { elementos composicionais quanto a questão da ortografia (por conta da intervenção } \\
\text { da aluna). } \\
\text { Alunos problematizam o uso do OU conjunção alternativa }\end{array}$ \\
\hline
\end{tabular}




\begin{tabular}{|c|c|c|c|c|c|c|}
\hline$\frac{\frac{\pi}{2}}{\frac{3}{2}}$ & $\begin{array}{l}\text { Matheus e } \\
\text { Eduardo }\end{array}$ & $19^{\prime} 00^{\prime \prime}$ & $\begin{array}{l}\text { Acentuação no } \\
\text { teclado }\end{array}$ & $\begin{array}{l}\text {-teclado } \\
\text {-editor de texto }\end{array}$ & $D$ & $\begin{array}{l}\text { Interessantes hipóteses que o aluno cria sobre os problemas ortográficos na palavra } \\
\text { VOCE }\end{array}$ \\
\hline$\frac{\frac{\pi}{2}}{\frac{3}{3}}$ & $\begin{array}{l}\text { Trabalho Lais } \\
\text { e Renata }\end{array}$ & $\begin{array}{l}22^{\prime} 00^{\prime} \\
28^{\prime} 00^{\prime \prime}\end{array}$ & $\begin{array}{l}\text { - Planejamento } \\
\text { oral } \\
\text { - Textualização } \\
\text { - Referente/ } \\
\text { Significação de } \\
\text { palavras típicas } \\
\text { do jogo } \\
\text { - Segmentação }\end{array}$ & $\begin{array}{l}\text {-teclado } \\
\text {-editor de texto }\end{array}$ & $D$ & $\begin{array}{l}\text { Trecho bastante interessante: } \\
\text { - A grafia de artigos que antecedem palavras iniciadas pela mesma letra (O OUTRO) } \\
\text { gera um obstáculo na textualização } \\
\text { as alunas já começam a criar uma espécie de vocabulário próprio do jogo (significado } \\
\text { de RAPS). } \\
\text { - Uso de artigo que antecede palavra com a inicial idêntica (O OUTRO) }\end{array}$ \\
\hline
\end{tabular}

\begin{tabular}{|c|c|c|c|}
\hline Turma: 3으 & SEQUÊNCIA DIDÁTICA: & RJ & ATIVIDADE: 3 - Leitura aplicada Jo-Ken-Po \\
\hline \multicolumn{3}{|c|}{ Pesquisadora: Heloisa Jordão } & Professora colaboradora: J. \\
\hline \multicolumn{3}{|c|}{ Ambiente: Lab Info } & Total de gravação: 25'40" \\
\hline Data: 09/09/16 & \multicolumn{2}{|l|}{ Mídia: 3B_090916 } & Total a ser transcrito: $17^{\prime}$ ao $22^{\prime}$ \\
\hline
\end{tabular}

\begin{tabular}{|c|c|c|c|c|c|c|}
\hline Cam & \multirow[t]{2}{*}{ EVENTO } & \multirow{2}{*}{$\begin{array}{l}\text { TEMPO } \\
\text { min'seg" } \\
\text { Arquivo }\end{array}$} & \multicolumn{3}{|c|}{ Elementos da interação } & RESUMO NARRATIVIZADO \\
\hline 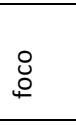 & & & $\begin{array}{l}\text { OBJETO DE } \\
\text { ENSINO }\end{array}$ & $\begin{array}{l}\text { INSTRUMENTO } \\
\text { DIDÁTICO }\end{array}$ & $\begin{array}{l}\text { formas } \\
\text { sociais } \\
\text { trabalho }\end{array}$ & \\
\hline $\begin{array}{l}\bar{\pi} \\
\bar{\Perp} \\
0\end{array}$ & $\begin{array}{l}\text { Retomada da } \\
\text { situação } \\
\text { comunicativa }\end{array}$ & $\begin{array}{l}00^{\prime \prime \prime} \\
02^{\prime} 39^{\prime \prime}\end{array}$ & $\begin{array}{l}\text { - Produção de } \\
\text { texto }\end{array}$ & $\begin{array}{l}\text { - perguntas didáticas. } \\
\text { - tela bloqueada }\end{array}$ & Q & $\begin{array}{l}\text { Professora rememora os alunos sobre a produção trabalhada nas duas últimas aulas. } \\
\text { Retoma a proposta do campeonato, como situação comunicativa em que a regra escrita } \\
\text { será necessária. Coloca aos alunos que, por meio da análise das produções feitas até o } \\
\text { momento, o único ponto de convergência em todas as regras é o JKP para iniciar. }\end{array}$ \\
\hline $\begin{array}{l}\bar{\pi} \\
\stackrel{\pi}{\pi} \\
心\end{array}$ & $\begin{array}{l}\text { Instrução e } \\
\text { etapas de } \\
\text { execução } \\
\text { Tarefa } 1\end{array}$ & $\begin{array}{l}02^{\prime} 40^{\prime \prime} \\
04^{\prime} 50^{\prime \prime}\end{array}$ & $\begin{array}{l}\text { - Análise de texto } \\
\text { "Regra JKP" } \\
\text { - Uso de } \\
\text { maiúscula, }\end{array}$ & $\begin{array}{l}\text { - Regra do JKP } \\
\text { projetada na tela dos } \\
\text { alunos, } \\
\text { - Tarefa } 1+\text { técnica }\end{array}$ & M & $\begin{array}{l}\text { É apresentado aos alunos, por meio de projeção em suas telas, um texto com a Regra de } \\
\text { Jogo do JKP. O texto apresenta, além do conteúdo verbal, figuras. Alguns vocábulos foram } \\
\text { aglutinados de maneira proposital pelas professoras, no entanto, essa questão não é } \\
\text { abordada neste momento da aula. Após a leitura a professora pede que os alunos escrevam } \\
\text { seus nomes e salvem o doc na pasta correta. }\end{array}$ \\
\hline
\end{tabular}




\begin{tabular}{|c|c|c|c|c|c|c|}
\hline$\overline{\frac{\pi}{4}}$ & $\begin{array}{l}\text { Instrução } \\
\text { Tarefa } 2\end{array}$ & $\begin{array}{l}10^{\prime} 50^{\prime \prime} \\
11^{\prime} 51^{\prime \prime}\end{array}$ & $\begin{array}{l}\text { - Análise de texto } \\
\text { - Coerência }\end{array}$ & $\begin{array}{l}\text { - Editor de texto Word } \\
\text { - Tarefa } 2 \text { : leitura em } \\
\text { dupla }\end{array}$ & $M$ & $\begin{array}{l}\text { Professora elabora de maneira mais focada e completa a instrução da atividade: análise de } \\
\text { regra de jogo. Salienta o uso de figuras e a necessidade de executar o que está escrito, ou } \\
\text { seja, jogar para verificarem se as regras realmente funcionam (aqui foca a coerência?). Não } \\
\text { fala sobre segmentação. }\end{array}$ \\
\hline$\frac{\frac{\pi}{2}}{\frac{2}{0}}$ & $\begin{array}{l}\text { Trabalho } \\
\text { Gustavo F. } \\
\text { Nicolas } \\
\text { Tarefa } 3\end{array}$ & $\begin{array}{l}11^{\prime} 52^{\prime \prime} \\
14^{\prime} 40^{\prime \prime}\end{array}$ & $\begin{array}{l}\text { - Elementos do } \\
\text { gênero RJ } \\
\text {-Segmentação }\end{array}$ & $\begin{array}{l}\text { - editor de texto Word; } \\
\text { - Perguntas didáticas }\end{array}$ & $\mathrm{D}$ & $\begin{array}{l}\text { Durante o trabalho dos alunos a prof. se aproxima e começa a realizar perguntas didáticas } \\
\text { aos alunos especialmente sobre coerência da regra. Finda a leitura a professora pergunta se } \\
\text { há algum problema na grafia das palavras, focando a segmentação. }\end{array}$ \\
\hline$\frac{\frac{\pi}{2}}{2}$ & $\begin{array}{c}\text { Vanessa } \\
\text { Gustavo Pes. }\end{array}$ & $\begin{array}{l}17^{\prime} 40^{\prime \prime} \\
24^{\prime} 00^{\prime \prime}\end{array}$ & $\begin{array}{l}\text { - segmentação } \\
\text { - Tec: tecla } \\
\text { espaço }\end{array}$ & $\begin{array}{l}\text { - editor de texto Word; } \\
\text { - Perguntas didáticas }\end{array}$ & $\mathrm{D}$ & $\begin{array}{l}\text { A professora faz problematizações a dupla. Interessante momento capturado sobre } \\
\text { segmentação e a conjunção alternativa /OU/ }\end{array}$ \\
\hline $\begin{array}{l}\overline{\overline{0}} \\
\bar{\varpi} \\
0\end{array}$ & $\begin{array}{c}\text { Tarefa } 4 \\
\text { Jogo }\end{array}$ & $\begin{array}{l}24^{\prime} 00^{\prime \prime} \\
25^{\prime} 40^{\prime \prime}\end{array}$ & $\begin{array}{l}\text { - Leitura } \\
\text { - Coerencia }\end{array}$ & $\begin{array}{l}\text { - Regra do jogo } \\
\text { - Execução do jogo JKP }\end{array}$ & $Q$ & $\begin{array}{l}\text { A professora convida todos a acompanharem a leitura, ao final convida um aluno para jogar } \\
\text { o JKP e chama a atenção do grupo para um aspecto da regra que não estava sendo } \\
\text { observado. }\end{array}$ \\
\hline
\end{tabular}

\begin{tabular}{|c|c|c|c|}
\hline Turma: 3C & SEQUÊNCIA DIDÁTICA: & RJ & ATIVIDADE: 3 - Leitura Aplicada Jo-ken-po \\
\hline \multicolumn{3}{|c|}{ Pesquisadora: Heloisa Jordão } & Professora colaboradora: E. \\
\hline \multicolumn{3}{|c|}{ Ambiente: lab info } & Total de gravação: 21'30"' \\
\hline Data: 06/09/17 & \multicolumn{2}{|l|}{ Mídia: 3C_060916 } & Total a ser transcrito: \\
\hline
\end{tabular}


Mapeamento:

\begin{tabular}{|c|c|c|c|c|c|c|}
\hline Cam & \multirow[t]{2}{*}{ EVENTO } & \multirow{2}{*}{$\begin{array}{l}\text { TEMPO } \\
\text { min'seg" } \\
\text { Arquivo }\end{array}$} & \multicolumn{3}{|c|}{ Elementos da interação } & \multirow[t]{2}{*}{ RESUMO NARRATIVIZADO } \\
\hline $\begin{array}{l}0 \\
\text { O্ } \\
\end{array}$ & & & $\begin{array}{l}\text { OBJETO DE } \\
\text { ENSINO }\end{array}$ & $\begin{array}{l}\text { INSTRUMENTO } \\
\text { DIDÁTICO }\end{array}$ & $\begin{array}{l}\text { formas } \\
\text { sociais } \\
\text { trabalho }\end{array}$ & \\
\hline$\frac{\bar{T}}{\bar{D}}$ & $\begin{array}{l}\text { Retomada da } \\
\text { situação } \\
\text { comunicativa/ } \\
\text { Apresentação da } \\
\text { atividade }\end{array}$ & $\begin{array}{l}1 ' 10^{\prime \prime} \\
2^{\prime} 04^{\prime \prime}\end{array}$ & $\begin{array}{l}\text { - Leitura } \\
\text { - Análise de } \\
\text { texto }\end{array}$ & - Exposição oral & Q & $\begin{array}{l}\text { Professora cita que ela e a professora Ellen observaram que todos começam } \\
\text { o jogo dos cards fazendo um outro jogo, o Jo-Ken-Po. Com isso mostra a } \\
\text { necessidade de analisar a regra do JKP e estabelecer uma regra única. }\end{array}$ \\
\hline$\overline{\frac{\pi}{2}}$ & $\begin{array}{l}\text { Implementação } \\
\text { da primeira } \\
\text { tarefa }\end{array}$ & $\begin{array}{l}03^{\prime} 16^{\prime \prime} \\
08^{\prime} 34^{\prime \prime}\end{array}$ & $\begin{array}{l}\text { - Letra } \\
\text { Maiúscula } \\
\text { - Tec: salvar } \\
\text { doc no } \\
\text { Windows } \\
\text { explorer }\end{array}$ & $\begin{array}{l}\text { - Tarefa, } \\
\text { - Exemplifica } \\
\text { - Bloqueio de tela } \\
\text { com projeção. } \\
\text { - Projeção de texto } \\
\text { em editor de texto }\end{array}$ & Q & $\begin{array}{l}\text { "Então agora vocês vão receber o texto com a regra do JKP, vão colocar o } \\
\text { nome e vão salvar na pastinha". Observamos que essa primeira 'parte da } \\
\text { atividade' tem caráter mais técnico: colocar o nome dos alunos seguindo as } \\
\text { normas da LP e salvar na pasta correta. }\end{array}$ \\
\hline 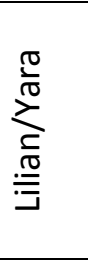 & $\begin{array}{l}\text { Implementação } \\
\text { da segunda } \\
\text { tarefa }\end{array}$ & $\begin{array}{l}08^{\prime} 35^{\prime \prime} \\
10^{\prime} 35^{\prime \prime}\end{array}$ & $\begin{array}{l}\text { - Leitura, } \\
\text { - Revisão } \\
\text { - Estrutura do } \\
\text { gênero RJ }\end{array}$ & $\begin{array}{l}\text { - Tarefa } \\
\text { - Projeção do texto } \\
\text { em editor de texto } \\
\text { nas telas dos } \\
\text { desktops }\end{array}$ & $\mathrm{D}$ & $\begin{array}{l}\text { Conforme os alunos terminam de salvar o doc. A prof solicita que iniciem a } \\
\text { leitura silenciosa. O texto apresenta problemas de segmentação de } \\
\text { vocábulos postos de forma proposital, no entanto a professora foca na } \\
\text { estrutura composicional do texto. Alguns alunos os localizam rapidamente e } \\
\text { as professoras realizam regulações locais para a execução da tarefa. Alunas } \\
\text { discutem problemas de segmentação. }\end{array}$ \\
\hline$\overline{\frac{\pi}{2}}$ & $\begin{array}{l}\text { Implementação } \\
\text { da terceira } \\
\text { tarefa }\end{array}$ & $\begin{array}{l}10^{\prime} 36^{\prime \prime} \\
11^{\prime} 10^{\prime \prime}\end{array}$ & $\begin{array}{l}\text { - Leitura } \\
\text { - Segmentação }\end{array}$ & $\begin{array}{l}\text { - Projeção do texto } \\
\text { em editor de texto } \\
\text { nas telas dos } \\
\text { desktops }\end{array}$ & Q & $\begin{array}{l}\text { Professora chama a atenção do grupo em relação aos problemas de } \\
\text { segmentação. }\end{array}$ \\
\hline 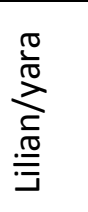 & $\begin{array}{l}\text { Realização das } \\
\text { tarefas } 2 \text { e } 3\end{array}$ & $\begin{array}{l}11^{\prime} 10^{\prime \prime} \\
13^{\prime} 40^{\prime \prime}\end{array}$ & $\begin{array}{l}\text { - Leitura } \\
\text { - Segmentação }\end{array}$ & & $\mathrm{D}$ & $\begin{array}{l}\text { Alunas discutem problemas de segmentação. Interessante que quando há } \\
\text { monossílabas aglutinadas a outras palavras há maior dificuldade em } \\
\text { observar o desvio ortográfico. }\end{array}$ \\
\hline
\end{tabular}




\begin{tabular}{|c|c|c|c|c|c|c|}
\hline 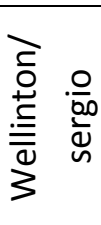 & $\begin{array}{l}\text { Realização das } \\
\text { tarefas } 2 \text { e } 3\end{array}$ & $13^{\prime} 40^{\prime \prime}$ & $\begin{array}{l}\text { - Leitura } \\
\text { - Segmentação }\end{array}$ & & D & $\begin{array}{l}\text { Alunos discutem problemas de segmentação. Interessante que quando há } \\
\text { monossílabas aglutinadas a outras palavras há maior dificuldade em } \\
\text { observar o desvio ortográfico. Professora E. realiza regulações locais. }\end{array}$ \\
\hline 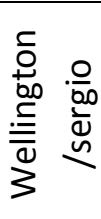 & $\begin{array}{l}\text { Implementação } \\
\text { da tarefa } 4\end{array}$ & $16^{\prime} 04^{\prime \prime}$ & $\begin{array}{l}\text { - Leitura } \\
\text { - Coerencia } \\
\text { textual }\end{array}$ & $\begin{array}{l}\text { - Leitura aplicada } \\
\text { - repetições } \\
\text { - paráfrases } \\
\text { - Perguntas } \\
\text { didáticas }\end{array}$ & $\mathrm{Q} / \mathrm{D}$ & $\begin{array}{l}\text { A professora solicita que os alunos salvem as alterações feitas, leiam as } \\
\text { regras em voz alta e conforme a leitura é feita, devem realizar as ações } \\
\text { prescritas no jogo. A prof E. acompanha o jogo dos alunos, questionando as } \\
\text { ações e relacionando-as com o conteúdo escrito. }\end{array}$ \\
\hline$\frac{\bar{T}}{\bar{D}}$ & $\begin{array}{l}\text { Realização da } \\
\text { tarefa } 4\end{array}$ & $19^{\prime} 30^{\prime \prime}$ & $\begin{array}{l}\text { - Leitura } \\
\text { - Coerencia } \\
\text { textual }\end{array}$ & $\begin{array}{l}\text {-leitura aplicada } \\
\text { - Coerencia }\end{array}$ & D & $\begin{array}{l}\text { Alunos e professoras jogam o Jo-ken Po. A professora observa que a parte } \\
\left.\text { final da regra não está sendo observada (aos } 22^{\prime} 00^{\prime \prime}\right) \text {. }\end{array}$ \\
\hline
\end{tabular}




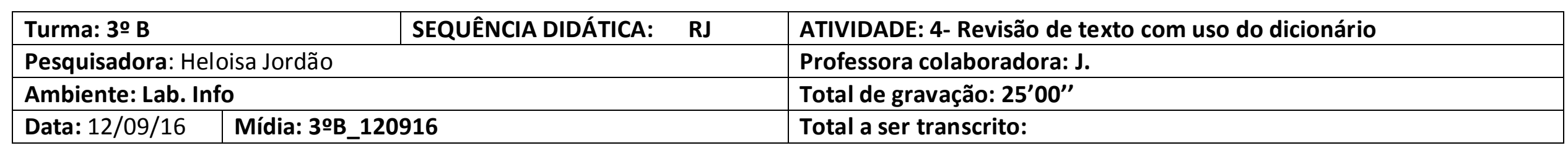

\section{Mapeamento:}

\begin{tabular}{|c|c|c|c|c|c|c|}
\hline Cam & \multirow[t]{2}{*}{ EVENTO } & \multirow{2}{*}{$\begin{array}{l}\text { TEMPO } \\
\text { min'seg" } \\
\text { Arquivo }\end{array}$} & \multicolumn{3}{|c|}{ Elementos das interação } & RESUMO NARRATIVIZADO \\
\hline 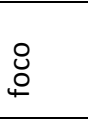 & & & $\begin{array}{l}\text { OBJETO DE } \\
\text { ENSINO }\end{array}$ & INSTRUMENTO DIDÁTICO & $\begin{array}{l}\text { FORMAS } \\
\text { SOCIAIS } \\
\text { TRABALHO }\end{array}$ & \\
\hline $\begin{array}{l}\overline{0} \\
\frac{\pi}{2} \\
\infty\end{array}$ & $\begin{array}{l}\text { Abertura da } \\
\text { aula }\end{array}$ & $\begin{array}{l}0^{\prime} 00^{\prime \prime} \\
1^{\prime} 40^{\prime \prime}\end{array}$ & $\begin{array}{l}\text { - Produção de } \\
\text { texto } \\
\text {-Revisão }\end{array}$ & $\begin{array}{l}\text { - exposição oral } \\
\text { - telas bloqueadas }\end{array}$ & $\mathrm{M}$ & Prof rememora o que havia sido feito na aula anterior \\
\hline $\begin{array}{l}\overline{0} \\
\frac{\pi}{2} \\
\infty\end{array}$ & $\begin{array}{l}\text { Revisão } \\
\text { coletiva do } \\
\text { texto }\end{array}$ & $\begin{array}{l}1^{\prime} 41^{\prime \prime} \\
07^{\prime} 50^{\prime \prime}\end{array}$ & $\begin{array}{l}\text { - revisão: coesão } \\
\text { textual, } \\
\text {-uso de figuras } \\
\text {-segmentação } \\
\text { - tec: tecla space }\end{array}$ & $\begin{array}{l}\text { - projeção do texto nos pcs } \\
\text { dos alunos; } \\
\text { - perguntas didáticas } \\
\text { - Elementos do gênero RJ }\end{array}$ & Q & $\begin{array}{l}\text { Utilizando o mesmo texto da semana anterior (regra do jogo JO-KEN-PO) a professora } \\
\text { envia a sua própria tela para a tela dos alunos e realiza uma grande revisão do texto. } \\
\text { Especial atenção para o gesto da Institucionalização (marca que o uso de figuras é } \\
\text { típico do gênero RJ). }\end{array}$ \\
\hline $\begin{array}{l}\overline{\frac{\pi}{2}} \\
\frac{1}{0}\end{array}$ & $\begin{array}{l}\text { Problema das } \\
\text { palavras que } \\
\text { não sabemos } \\
\text { o significado }\end{array}$ & $\begin{array}{l}09^{\prime} 10^{\prime \prime} \\
11^{\prime} 40^{\prime \prime}\end{array}$ & & $\begin{array}{l}\text { - texto JKP projetado nos } \\
\text { pcs dos alunos com a } \\
\text { palavra AMBOS salientada }\end{array}$ & Q & $\begin{array}{l}\text { Na leitura do texto surge o vocábulo "ambos" e a professora problematiza a questão } \\
\text { da significação: onde buscar respostas para palavras que não sabemos o significado? }\end{array}$ \\
\hline $\begin{array}{l}\overline{\frac{\pi}{0}} \\
\frac{1}{0} \\
0\end{array}$ & $\begin{array}{l}\text { Exemplificação } \\
\text { de uso do } \\
\text { dicionário on } \\
\text { line. }\end{array}$ & $\begin{array}{l}11^{\prime} 40^{\prime \prime} \\
15^{\prime} 30^{\prime \prime}\end{array}$ & $\begin{array}{l}\text { - dicionário (uso) } \\
\text { - leiaute web } \\
\text {-caixa de busca }\end{array}$ & $\begin{array}{l}\text { - dicionário on line } \\
\text { projetado }\end{array}$ & Q & $\begin{array}{l}\text { A professora exemplifica por meio de projeção nas telas dos alunos o uso de } \\
\text { dicionário buscando o vocábulo cachorro. Leem as diferentes acepções da palavra e } \\
\text { realizam uma breve discussão }\end{array}$ \\
\hline
\end{tabular}




\begin{tabular}{|c|c|c|c|c|c|c|}
\hline $\begin{array}{l}\overline{0} \\
\frac{\pi}{d} \\
\text { مo }\end{array}$ & $\begin{array}{l}\text { Elaboração da } \\
\text { comanda da } \\
\text { tarefa }\end{array}$ & $15^{\prime} 31^{\prime \prime}$ & - segmentação & - editor de texto & Q/D & $\begin{array}{l}\text { Descubra o significado de ambos e substitua no texto do JKP. Apesar de dar essa } \\
\text { comanda, a prof busca ter certeza que todos conseguem ajustar os problemas de } \\
\text { segmentação que estavam sendo tratados desde a última aula. }\end{array}$ \\
\hline$\frac{\frac{\pi}{2}}{\frac{2}{7}}$ & $\begin{array}{l}\text { Trabalho } \\
\text { Giovani } \\
\text { Beatriz }\end{array}$ & $19^{\prime} 37^{\prime \prime}$ & $\begin{array}{l}\text { - uso do } \\
\text { dicionário } \\
\text { - tec: } \\
\text { mecanismos de } \\
\text { busca }\end{array}$ & $\begin{array}{l}\text { - site dicionário on line } \\
\text { caldas aulete aberto } \\
\text { - }\end{array}$ & D & $\begin{array}{l}\text { Agora os alunos tem as telas liberadas com o browser aberto na página do dicionário } \\
\text { on-line segundo a comanda: Descubra o significado de ambos e substitua no texto do } \\
\text { JKP. }\end{array}$ \\
\hline
\end{tabular}




\begin{tabular}{|c|c|c|c|}
\hline Turma: 3ㅇ C & SEQUÊNCIA DIDÁTICA: & RJ & ATIVIDADE: 4 - Revisão de texto com uso do dicionário \\
\hline \multicolumn{3}{|c|}{ Pesquisadora: Heloisa Jordão } & Professora colaboradora: E. \\
\hline \multicolumn{3}{|c|}{ Ambiente: Lab. Info } & Total de gravação:37'00'” \\
\hline Data: 13/09/16 & \multicolumn{2}{|l|}{ Mídia: 3C_130916 } & Total a ser transcrito: \\
\hline
\end{tabular}

\section{Mapeamento:}

\begin{tabular}{|c|c|c|c|c|c|c|}
\hline Cam & \multirow{2}{*}{$\begin{array}{l}\text { EVENTO } \\
\text { Tarefas }\end{array}$} & \multirow{2}{*}{$\begin{array}{l}\text { TEMPO } \\
\text { min'seg" } \\
\text { Arquivo }\end{array}$} & \multicolumn{3}{|c|}{ Elementos da interação } & \multirow[t]{2}{*}{ RESUMO NARRATIVIZADO } \\
\hline 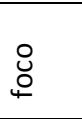 & & & $\begin{array}{l}\text { OBJETO DE } \\
\text { ENSINO }\end{array}$ & INSTRUMENTO DIDÁTICO & $\begin{array}{l}\text { FORMAS } \\
\text { SOCIAIS } \\
\text { TRABALHO }\end{array}$ & \\
\hline $\begin{array}{l}\overline{\frac{\pi}{0}} \\
\bar{d} \\
\text { D. }\end{array}$ & $\begin{array}{l}\text { Retomada da } \\
\text { aula anterior }\end{array}$ & $07^{\prime} 30^{\prime \prime}$ & $\begin{array}{l}\text { - regra de jogo: } \\
\text { estrutura } \\
\text { composicional }\end{array}$ & $\begin{array}{l}\text { - Exposição oral } \\
\text { - Telas bloqueadas (azul) }\end{array}$ & Q & $\begin{array}{l}\text { Professora retoma a atividade da aula anterior e problematiza o pq estarem } \\
\text { realizando o trabalho com a regra do JKP se pretendem escrever a regra do cards. Os } \\
\text { alunos dão suas contribuições. O texto utilizado será o mesmo da aula anterior. }\end{array}$ \\
\hline $\begin{array}{l}\bar{\pi} \\
\frac{\pi}{2} \\
00\end{array}$ & $\begin{array}{l}\text { Revisão } \\
\text { coletiva de } \\
\text { texto }\end{array}$ & $08^{\prime} 10^{\prime \prime}$ & $\begin{array}{l}\text { - Estrutura do } \\
\text { gênero RJ; } \\
\text { - Segmentação }\end{array}$ & $\begin{array}{l}\text { - texto da aula projetado } \\
\text { nas telas dos desktops; } \\
\text { - Leitura em voz alta (prof } \\
\text { e alunos) } \\
\text { - Perguntas didáticas }\end{array}$ & Q & $\begin{array}{l}\text { É realizada a leitura do texto e ao longo da leitura a professora realiza perguntas } \\
\text { focalizando aspectos específicos da estrutura do gênero textual RJ. Questiona se a } \\
\text { regra foi escrita corretamente e vão realizando ajustes, tanto em relação ao conteúdo } \\
\text { composicional e em relação aos problemas de segmentação. Chama atenção à } \\
\text { relação entre o que está escrito e o que é representado por meio de desenhos/figuras } \\
\left(14^{\prime} 20^{\prime \prime}\right)\end{array}$ \\
\hline $\begin{array}{l}\overline{0} \\
\frac{\pi}{2} \\
0\end{array}$ & $\begin{array}{l}\text { Construção de } \\
\text { quadro com } \\
\text { os elementos } \\
\text { do gênero RJ }\end{array}$ & $16^{\prime} 20^{\prime \prime}$ & $\begin{array}{l}\text { - Estrutura do } \\
\text { gênero RJ; }\end{array}$ & $\begin{array}{l}\text { - Televisão com placa } \\
\text { projetada }\end{array}$ & $Q$ & $\begin{array}{l}\text { "O que não pode faltar em uma regra de jogo" } \\
\text { - Nome da brincadeira,- Número de participantes, - Deve conter figuras } \\
\text { A partir da leitura da regra do JKP professora vai dirigindo a atenção dos alunos aos } \\
\text { elementos do gênero RJ. (ao longo da leitura continuam resolvendo problemas de } \\
\text { segmentação, foco da aula anterior) }\end{array}$ \\
\hline
\end{tabular}




\begin{tabular}{|c|c|c|c|c|c|c|}
\hline $\begin{array}{l}\overline{\frac{\pi}{d}} \\
\frac{0}{0}\end{array}$ & $\begin{array}{l}\text { Problema de } \\
\text { segmentação } \\
\text { da palavra } \\
\text { geralmente }\end{array}$ & $19^{\prime} 30^{\prime \prime}$ & $\begin{array}{l}\text { - ortografia } \\
\text { - uso de } \\
\text { dicionário on line }\end{array}$ & $\begin{array}{l}\text { - Dicionário on line } \\
\text { projetado na tela e na TV } \\
\text { - Tarefa: busque a palavra } \\
\text { "ambos" no dicionário (23" } \\
\left.20^{\prime \prime}\right)\end{array}$ & $Q$ & $\begin{array}{l}\text { Problema de segmentação da palavra "geralmente". A professora problematiza como } \\
\text { buscar respostas a esse problema e apresenta o dicionário. ( }\left(21^{\prime} 00^{\prime \prime}\right)\end{array}$ \\
\hline $\begin{array}{l}\overline{\frac{\pi}{d}} \\
\frac{0}{00}\end{array}$ & $\begin{array}{l}\text { Última revisão } \\
\text { do texto } \\
\text { abordado na }\end{array}$ & $25^{\prime} 00^{\prime \prime}$ & $\begin{array}{l}\text { - Segmentação } \\
\text { - Estrutura do } \\
\text { gênero RJ }\end{array}$ & $\begin{array}{l}\text { - Desbloqueio da tela, } \\
\text { - Acesso ao documento na } \\
\text { pasta da dupla de trabalho }\end{array}$ & D & $\begin{array}{l}\text { Os alunos devem abrir o documento com o texto da regra jokenpo, revisar se os } \\
\text { vocábulos foram segmentados da forma correta. }\end{array}$ \\
\hline$\stackrel{0}{\frac{N}{3}} \frac{0}{\frac{d}{\partial}}$ & & $28^{\prime} 30^{\prime \prime}$ & & $\begin{array}{l}\text { - Site do dicionário on line } \\
\text { caldas aulete aberto para } \\
\text { consulta dos alunos }\end{array}$ & $D$ & $\begin{array}{l}\text { Pesquisar no dicionário o significado da palavra /ambos/ e substitui-la no texto por } \\
\text { um termo equivalente }\end{array}$ \\
\hline $\begin{array}{l}\overline{0} \\
\frac{\pi}{d} \\
0\end{array}$ & $\begin{array}{l}\text { Reorganização } \\
\text { da interação: }\end{array}$ & $32^{\prime} 00^{\prime \prime}$ & & $\begin{array}{l}\text { - Telas bloqueadas } \\
\text { - repetição das tarefas que } \\
\text { deveriam ter sido } \\
\text { executadas }\end{array}$ & $Q$ & $\begin{array}{l}\text { Professora chama a atenção de um grupo que não estava realizando a tarefa } \\
\text { adequadamente. Repete as etapas das tarefas e focaliza o significado da palavra } \\
\text { ambos. Solicita que as duplas que já conseguiram desempenhar a tarefa auxiliem as } \\
\text { duplas que ainda não a fizeram. Garantir que todos caminhem juntos na realização da } \\
\text { tarefa. }\end{array}$ \\
\hline
\end{tabular}




\begin{tabular}{|l|l|l|}
\hline Turma: 3B & SEQUÊNCIA DIDÁTICA: RJ & ATIVIDADE: Reescrita coletiva de texto \\
\hline Pesquisadora: Heloisa Jordão & Professora colaboradora: J. \\
\hline Ambiente: Lab. Info & Total de gravação: 21' 43" \\
\hline Data: $16 / 09 / 16 \quad$ Mídia:3B_160916 & Total a ser transcrito: \\
\hline
\end{tabular}

Mapeamento: Atividade 5 - Reescrita coletiva de texto

Obs:É a primeira aula da SD que os alunos não estão organizados em duplas. As cadeiras estão dispostas no centro da sala e a atenção dos alunos está voltada a Televisão. Esta projeta um texto produzido por um aluno

\begin{tabular}{|c|c|c|c|c|c|c|}
\hline Cam & \multirow{2}{*}{$\begin{array}{l}\text { EVENTO } \\
\text { Tarefas }\end{array}$} & \multirow{2}{*}{$\begin{array}{l}\text { TEMPO } \\
\text { min'seg" } \\
\text { Arquivo }\end{array}$} & & & & \multirow[t]{2}{*}{ RESUMO NARRATIVIZADO } \\
\hline 巳 & & & $\begin{array}{l}\text { OBJETO DE } \\
\text { ENSINO }\end{array}$ & INSTRUMENTO DIDÁTICO & $\begin{array}{l}\text { formas } \\
\text { sociais } \\
\text { trabalho }\end{array}$ & \\
\hline $\begin{array}{l}\overline{\frac{\pi}{2}} \\
\frac{0}{0}\end{array}$ & $\begin{array}{l}\text { Abertura da } \\
\text { atividade }\end{array}$ & $\begin{array}{l}0^{\prime} 00^{\prime \prime} \\
4^{\prime} 40^{\prime \prime}\end{array}$ & $\begin{array}{l}\text { - Produção de } \\
\text { texto } \\
\text { - Elementos do } \\
\text { gênero RJ }\end{array}$ & $\begin{array}{l}\text { - Mural com os elementos } \\
\text { do gênero dispostos em } \\
\text { um pequeno cartaz, } \\
\text { - Perguntas didáticas; } \\
\text { - Exemplificações }\end{array}$ & $Q$ & $\begin{array}{l}\text { A professora rememora todo o percurso da SD até o momento. Com o auxílio de um } \\
\text { cartaz afixado no mural da sala, trata de cada aspecto típico deste gênero textual. }\end{array}$ \\
\hline
\end{tabular}




\begin{tabular}{|c|c|c|c|c|c|c|}
\hline $\begin{array}{l}\bar{\pi} \\
\frac{\pi}{0} \\
0\end{array}$ & $\begin{array}{l}\text { Leitura } \\
\text { coletiva de } \\
\text { texto } \\
\text { produzido } \\
\text { por aluno e } \\
\text { correção }\end{array}$ & $\begin{array}{l}4,41^{\prime \prime} \\
20^{\prime} 00^{\prime \prime}\end{array}$ & $\begin{array}{l}\text { - Elementos do } \\
\text { gênero RJ; } \\
\text { - coesão; } \\
\text { - coerência; } \\
\text { - segmentação. } \\
\text { - concordância } \\
\text { número pessoal }\end{array}$ & $\begin{array}{l}\text { - texto escrito por aluno } \\
\text { - Televisão com texto } \\
\text { projetado } \\
\text { - Editor de texto Word }\end{array}$ & $\mathrm{Q}$ & $\begin{array}{l}\text { Professora apresenta uma regra de jogo escrita por um colega do 30 ano C, projetada } \\
\text { na Televisão. Conforme realizam a leitura vão discutindo os elementos do gênero, } \\
\text { acrescentando ou adaptando o que é necessário, conforme os aspectos apontados no } \\
\text { cartaz. Como este exercício é feito no editor de texto, as correções são assinaladas } \\
\text { em vermelho. Aos 15' um aluno observa que a professora inseriu uma sequencia } \\
\text { textual e deixou dois vocábulos sem segmentação. } \\
\text { A correção centra-se em elementos estruturais do gênero, a princípio. Em seguida } \\
\text { percebem a necessidade de inserir um conteúdo que não constava no texto objeto de } \\
\text { análise da aula (18'). Nesta ocasião discutem sobre o significado de diversos termos } \\
\text { típicos do jogo. }\end{array}$ \\
\hline
\end{tabular}

\section{Turma: 3ㅇ C}

Pesquisadora: Heloisa Jordão

Ambiente: Lab. Info

Data: 16/09/16

Mídia: 3ำ 160916
SEQUÊNCIA DIDÁTICA:

RJ

J

Pr

\section{Professora colaboradora: E. \\ Total de gravação: 20'00"'}

Total a ser transcrito: 
Mapeamento: Atividade $\mathbf{5}$

Obs: as cadeiras dos alunos estão organizadas no centro da sala de modo que todos tenham seus rostos voltados para a TV

\begin{tabular}{|c|c|c|c|c|c|c|}
\hline Cam & \multirow{2}{*}{$\begin{array}{l}\text { EVENTO } \\
\text { Tarefas }\end{array}$} & \multirow{2}{*}{$\begin{array}{l}\text { TEMPO } \\
\text { min'seg" } \\
\text { Arquivo }\end{array}$} & \multicolumn{3}{|c|}{ FORMAS SOCIAIS DE TRABALHO } & RESUMO NARRATIVIZADO \\
\hline 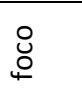 & & & $\begin{array}{l}\text { OBJETO DE } \\
\text { ENSINO }\end{array}$ & INSTRUMENTO DIDÁTICO & & \\
\hline $\begin{array}{l}\bar{\pi} \\
\overline{0} \\
0\end{array}$ & $\begin{array}{l}\text { Tarefa: } \\
\text { Leitura } \\
\text { silenciosa }\end{array}$ & $6^{\prime} 00^{\prime \prime}$ & $\begin{array}{l}\text { - Estrutura do } \\
\text { gênero RJ }\end{array}$ & $\begin{array}{l}\text { - Texto projetado em uma } \\
\text { TV } \\
\text { - Editor de texto }\end{array}$ & I & $\begin{array}{l}\text { A professora projeta na TV um texto da RJ cards escrito por uma dupla de alunos da } \\
\text { outra sala. }\end{array}$ \\
\hline $\begin{array}{l}\bar{\pi} \\
\overline{0} \\
0\end{array}$ & $\begin{array}{l}\text { Tarefa: } \\
\text { Análise de } \\
\text { texto a partir } \\
\text { de quadro de } \\
\text { elementos }\end{array}$ & $75^{\prime \prime}$ & $\begin{array}{l}\text { - Estrutura do } \\
\text { gênero RJ }\end{array}$ & $\begin{array}{l}\text { - Texto projetado em uma } \\
\text { TV } \\
\text { - Editor de texto. } \\
\text { - Câmera fotográfica do } \\
\text { celular }\end{array}$ & C & $\begin{array}{l}\text { Realizando questionamentos aos alunos, sempre consultando o quadro construido pelo } \\
\text { grupo, a professora dirige a análise do texto projetado. Como este exercício é feito no } \\
\text { editor de texto, as correções são assinaladas em verde. } \\
\text { Aos 9'00" surge um problema de referência: alguns alunos discordam do termo utilizado } \\
\text { no texto (tapinha) e alegam que o correto é "mãozinha" } \\
\text { Aos } 14^{\prime} \text { ' surge o problema de exemplificar movimentos motores (bater as mãos de } \\
\text { formas específicas). Um aluno sugere a inserção de foto. Tiram as fotos para posterior } \\
\text { inserção. No momento, colocam duas formas retangulares no texto que estava sendo } \\
\text { analisado/corrigido. Problematiza em qual espaço do texto as figuras devem ser } \\
\text { inseridas. }\end{array}$ \\
\hline
\end{tabular}

\begin{tabular}{|c|c|c|c|}
\hline SEQUÊNCIA DIDÁTICA & RJ & Turma: 3ㅇ B & ATIVIDADE: 6 - Do texto coletivo para o texto individual \\
\hline \multicolumn{3}{|c|}{ Pesquisadora: Heloisa Jordão } & Professora colaboradora: J. \\
\hline \multicolumn{3}{|l|}{ Ambiente: Lab. Info } & Total de gravação: 20’50"' \\
\hline Data: $23 / 09 / 2016$ & Mídi & B_230916 & Total a ser transcrito: do $12^{\prime}$ ao $19^{\prime}$ \\
\hline
\end{tabular}




\section{Mapeamento:}

\begin{tabular}{|c|c|c|c|c|c|c|}
\hline Cam & \multirow[t]{2}{*}{ EVENTO } & \multirow{2}{*}{$\begin{array}{l}\text { TEMPO } \\
\text { min'seg" } \\
\text { Arquivo }\end{array}$} & \multicolumn{3}{|c|}{ Elementos da interação didática } & \multirow[b]{2}{*}{ RESUMO NARRATIVIZADO } \\
\hline 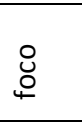 & & & $\begin{array}{l}\text { OBJETO DE } \\
\text { ENSINO }\end{array}$ & INSTRUMENTO DIDÁTICO & $\begin{array}{l}\text { FORMAS } \\
\text { SOCIAIS DE } \\
\text { TRABALHO }\end{array}$ & \\
\hline $\begin{array}{l}\bar{\pi} \\
\frac{0}{0} \\
00\end{array}$ & Preparação & $\begin{array}{l}0^{\prime} 00^{\prime \prime} \text { até } \\
2^{\prime} 00^{\prime \prime}\end{array}$ & $\begin{array}{l}\text { Produção de } \\
\text { texto }\end{array}$ & $\begin{array}{l}\text { - Computadores dos alunos } \\
\text { bloqueados; } \\
\text { - Projeção de texto com } \\
\text { marcas de revisão (cores } \\
\text { diferenciadas) }\end{array}$ & $\begin{array}{l}\text { M- } \\
\text { exposição } \\
\text { professora }\end{array}$ & Professora abre a aula rememorando que foi desenvolvido até o momento. \\
\hline 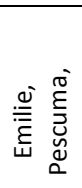 & $\begin{array}{l}\text { Desenvolvimento } \\
\text { (finalização da } \\
\text { revisão de texto } \\
\text { coletiva) }\end{array}$ & $\begin{array}{l}4^{\prime} 50^{\prime \prime} \text { até os } \\
5^{\prime} 10^{\prime \prime}\end{array}$ & $\begin{array}{l}\text { - Revisão de } \\
\text { texto; } \\
\text { - coesão; }\end{array}$ & $\begin{array}{l}\text { - Projeção de texto único na } \\
\text { tela de todos os } \\
\text { computadores; } \\
\text { - Leitura em voz alta; }\end{array}$ & $\begin{array}{l}\text { M- } \\
\text { exposição } \\
\text { professora }\end{array}$ & $\begin{array}{l}\text { Projetando o mesmo texto trabalhado na aula anterior a professora finaliza a } \\
\text { revisão do texto produzido por uma das duplas de alunos. }\end{array}$ \\
\hline$\frac{\frac{\pi}{0}}{\frac{2}{7}}$ & $\begin{array}{l}\text { Desenvolvimento } \\
\text { ( revisão de texto } \\
\text { em duplas) } \\
\text { Wanessa e } \\
\text { Gustavo }\end{array}$ & $\begin{array}{l}12^{\prime} 00^{\prime \prime} \\
\text { Até } 17^{\prime}\end{array}$ & $\begin{array}{l}\text { - Revisão de } \\
\text { texto; } \\
\text { - Ortografia } \\
\text { (homofonia) } \\
\text { - Uso do teclado }\end{array}$ & $\begin{array}{l}\text { - texto elaborado pela dupla } \\
\text { nas aulas anteriores; } \\
\text { - Editor de texto (corretor } \\
\text { ortográfico) }\end{array}$ & $\mathrm{D}$ & $\begin{array}{l}\text { Os alunos leem o que já haviam produzido e começam a observar as marcas } \\
\text { apontadas pelo corretor automático do editor de textos. Reflexão sobre o uso } \\
\text { de S ou Ç para grafar a palavra "matança" de acordo com os feedbacks do } \\
\text { corretor ortográfico. }\end{array}$ \\
\hline
\end{tabular}




\begin{tabular}{|c|c|c|c|c|c|c|}
\hline$\frac{\frac{\pi}{0}}{\frac{0}{7}}$ & $\begin{array}{l}\text { Desenvolvimento } \\
\text { ( revisão de texto } \\
\text { em duplas) } \\
\text { Wanessa e } \\
\text { Gustavo }\end{array}$ & $\begin{array}{l}\text { aos } 17^{\prime} 00^{\prime} \\
\text { até os } \\
19^{\prime} 00^{\prime \prime}\end{array}$ & $\begin{array}{l}\text { - Revisão de } \\
\text { texto } \\
\text { - Ortografia } \\
\text { (apoio na } \\
\text { oralidade, } \\
\text { acentuação) } \\
\text { - Uso do teclado }\end{array}$ & $\begin{array}{l}\text { - texto elaborado pela dupla } \\
\text { nas aulas anteriores; } \\
\text { - Editor de texto (corretor } \\
\text { ortográfico) }\end{array}$ & $D$ & $\begin{array}{l}17^{\prime} 00^{\prime \prime} \text { : há um interessante movimento de correção - os alunos pensam em } \\
\text { inserir um verbo na sentença mas ao retornar ao ponto, apagando outros } \\
\text { trechos, os alunos se confundem e ignoram o acréscimo planejado e se focam } \\
\text { em uma questão ortográfica }\end{array}$ \\
\hline
\end{tabular}

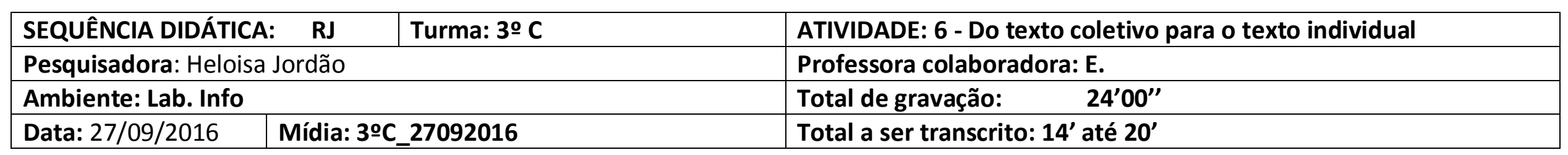

Mapeamento:

\begin{tabular}{|c|c|c|c|c|c|c|}
\hline Cam & \multirow[t]{2}{*}{ EVENTO } & \multirow{2}{*}{$\begin{array}{l}\text { TEMPO } \\
\text { min'seg" } \\
\text { Arquivo }\end{array}$} & \multicolumn{3}{|c|}{ Elementos da interação } & RESUMO NARRATIVIZADO \\
\hline 巳 & & & $\begin{array}{c}\text { OBJETO DE } \\
\text { ENSINO }\end{array}$ & INSTRUMENTO DIDÁTICO & $\begin{array}{l}\text { FORMAS } \\
\text { SOCIAIS DE } \\
\text { TRABALHO }\end{array}$ & \\
\hline $\begin{array}{l}\overline{\frac{\pi}{0}} \\
\overline{0}\end{array}$ & $\begin{array}{l}\text { Preparação } \\
\text { - finalização da } \\
\text { revisão coletiva } \\
\text { de texto }\end{array}$ & $\begin{array}{l}0^{\prime} 00^{\prime \prime} \text { até } \\
1^{\prime} 00^{\prime \prime}\end{array}$ & $\begin{array}{l}\text { - Revisão de } \\
\text { texto }\end{array}$ & $\begin{array}{l}\text { - telas bloqueadas } \\
\text { - Projeção de texto com } \\
\text { marcas de revisão (cores } \\
\text { diferenciadas) }\end{array}$ & $\begin{array}{c}\mathrm{M}- \\
\text { Exposição } \\
\text { professora }\end{array}$ & Professora abre a aula rememorando que foi desenvolvido até o momento. \\
\hline
\end{tabular}




\begin{tabular}{|c|c|c|c|c|c|c|}
\hline $\begin{array}{l}\bar{\pi} \\
\frac{\pi}{0} \\
0\end{array}$ & $\begin{array}{l}\text { Desenvolvimento } \\
\text { (finalização da } \\
\text { revisão de texto } \\
\text { coletiva) }\end{array}$ & $\begin{array}{l}1^{\prime} 00^{\prime \prime} \text { até } \\
13^{\prime} 30^{\prime \prime}\end{array}$ & $\begin{array}{l}\text { - revisão de texto } \\
\text { - Inserção de } \\
\text { figuras no texto, } \\
\text { - Coesão } \\
\text { - ortografia }\end{array}$ & $\begin{array}{l}\text { - Projeção de texto único } \\
\text { na tela de todos os } \\
\text { computadores; } \\
\text { - Leitura em voz alta }\end{array}$ & $\begin{array}{c}\text { M - } \\
\text { Exposição } \\
\text { professora }\end{array}$ & $\begin{array}{l}\text { Projetando o mesmo texto trabalhado na aula anterior a professora finaliza a } \\
\text { revisão do texto produzido por uma das duplas de alunos. }\end{array}$ \\
\hline$\frac{\frac{\pi}{2}}{\frac{2}{7}}$ & $\begin{array}{l}\text { Desenvolvimento } \\
\text { ( revisão de texto } \\
\text { em duplas) } \\
\text { Keyla e Luiz }\end{array}$ & $\begin{array}{l}14^{\prime} 45^{\prime \prime} \text { até } \\
18^{\prime} 30^{\prime \prime} \\
18^{\prime} 31^{\prime \prime} \text { até } \\
20^{\prime} 00^{\prime \prime}\end{array}$ & $\begin{array}{l}\text { - Revisão de } \\
\text { texto; } \\
\text { - Ortografia } \\
\text { - Segmentação }\end{array}$ & $\begin{array}{l}\text { - texto elaborado pela } \\
\text { dupla nas aulas anteriores; } \\
\text { - Editor de texto (corretor } \\
\text { ortográfico) }\end{array}$ & $\begin{array}{l}\text { D - trabalho } \\
\text { em duplas }\end{array}$ & $\begin{array}{l}\text { A professora solicita que a dupla leia o que já foi produzido até o momento e } \\
\text { solicita que façam a revisão lembrando os tópicos abordados no trabalho de revisão } \\
\text { coletiva. } \\
18^{\prime} 31^{\prime \prime} \text { bons momentos de interação na revisão (segmentação). Os alunos } \\
\text { conseguem resolver um problema em um trecho do texto e replicam a solução em } \\
\text { outras ocorrências. }\end{array}$ \\
\hline
\end{tabular}

\begin{tabular}{|c|c|c|c|}
\hline \multicolumn{2}{|c|}{ SEQUÊNCIA DIDÁTICA: $\quad$ RJ } & Turma: 3음 & ATIVIDADE: 7 Inserindo Figuras \\
\hline \multicolumn{3}{|c|}{ Pesquisadora: Heloisa Jordão } & Professora colaboradora: J. \\
\hline \multicolumn{3}{|c|}{ Ambiente: Lab. Info } & Total de gravação: 25’ \\
\hline Data: 04/10/16 & \multicolumn{2}{|c|}{ Mídia: 3B_041016 } & Total a ser transcrito: \\
\hline
\end{tabular}

\section{Mapeamento:}

\begin{tabular}{|c|c|c|c|c|c|c|c|}
\hline Cam & \multirow[t]{2}{*}{ EVENTO } & \multirow{2}{*}{$\begin{array}{c}\text { TEMPO } \\
\text { min'seg" } \\
\text { Arquivo }\end{array}$} & \multicolumn{3}{|c|}{ Elementos da interação } & \multirow{2}{*}{$\begin{array}{c}\text { FORMAS } \\
\text { SOCIAIS DE } \\
\text { TRABALHO }\end{array}$} & \multirow[t]{2}{*}{ RESUMO NARRATIVIZADO } \\
\hline ¿ & & & OBJETO DE ENSINO & INSTRUMENTO DIDÁTICO & $\begin{array}{c}\text { GESTOS } \\
\text { PROFISSIONAIS }\end{array}$ & & \\
\hline
\end{tabular}




\begin{tabular}{|c|c|c|c|c|c|c|c|}
\hline $\begin{array}{l}\bar{\pi} \\
\frac{\pi}{d} \\
0\end{array}$ & $\begin{array}{l}\text { Abertura da } \\
\text { atividade }\end{array}$ & $\begin{array}{l}0^{\prime} 00^{\prime \prime} \\
1^{\prime} 30^{\prime \prime}\end{array}$ & - Produção de texto & $\begin{array}{l}\text { - discurso da prof } \\
\text { - telas bloqueadas }\end{array}$ & - memória didática & $Q$ & $\begin{array}{l}\text { Prof retoma o que foi feito nas últimas aulas e } \\
\text { questiona as marcas de revisão que foram feitas ao } \\
\text { longo da atividade de revisão coletiva }\end{array}$ \\
\hline $\begin{array}{l}\bar{\pi} \\
\frac{\pi}{d} \\
0\end{array}$ & $\begin{array}{l}\text { Explicação da } \\
\text { atividade }\end{array}$ & $\begin{array}{l}1^{\prime} 30 \\
8^{\prime} 50^{\prime \prime}\end{array}$ & $\begin{array}{l}\text { - Produção de texto } \\
\text { - Inserção de figuras }\end{array}$ & $\begin{array}{l}\text { - texto projetado nas telas } \\
\text { dos alunos. } \\
\text { - Leitura em voz alta } \\
\text { - explicação/exemplificação } \\
\text { - Formulação de tarefa }\end{array}$ & $\begin{array}{l}\text { - implementação de } \\
\text { dispositivo didático }\end{array}$ & $Q$ & $\begin{array}{l}\text { Explicação/exemplificação de como inserir figuras de } \\
\text { modo a complementar o sentido do texto. } \\
8^{\prime} 40^{\prime \prime} \text { professora formula a consigna }\end{array}$ \\
\hline$\frac{\frac{\pi}{0}}{\frac{0}{7}}$ & $\begin{array}{l}\text { Desenvolvimento } \\
\text { em duplas - } \\
\text { Alexandre e ? }\end{array}$ & $10^{\prime} 20^{\prime \prime}$ & - Inserção de figuras & - Editor de texto Word & Reformula a tarefa & $\mathrm{D}$ & $\begin{array}{l}\text { Alunos brincam com o ajuste da figura ao leiaute do } \\
\text { texto. }\end{array}$ \\
\hline$\frac{\frac{\pi}{0}}{\frac{0}{7}}$ & $\begin{array}{l}\text { Desenvolvimento } \\
\text { em duplas - } \\
\text { Alexandre e ? }\end{array}$ & $\begin{array}{l}17^{\prime} 00^{\prime \prime} \\
19^{\prime} 30^{\prime \prime}\end{array}$ & $\begin{array}{l}\text { - Revisão } \\
\text { - Inserção de figuras } \\
\text { - registro Fotografico }\end{array}$ & $\begin{array}{l}\text { - Editor de texto Word } \\
\text { - Câmera fotográfica }\end{array}$ & - Regulações locais & $\mathrm{D}$ & $\begin{array}{l}\text { Alunos sentem a necessidade de inserir mais imagens } \\
\text { do que as fotos disponíveis para a aula. então a } \\
\text { professora disponibiliza a câmera do celular }\end{array}$ \\
\hline$\frac{\frac{\pi}{0}}{\frac{0}{7}}$ & $\begin{array}{l}\text { Desenvolvimento } \\
\text { em duplas - } \\
\text { Emily e Ketlyn }\end{array}$ & $\begin{array}{l}20^{\prime} 00^{\prime \prime} \text { ao } \\
23^{\prime} 00^{\prime \prime}\end{array}$ & - Revisão & - Editor de texto Word & - Regulações locais & $\mathrm{D}$ & $\begin{array}{l}\text { - Após inserirem as figuras a professora solicita que as } \\
\text { alunas releiam e observem se o texto precisa de mais } \\
\text { algum ajuste. Pouca interação entre a dupla }\end{array}$ \\
\hline
\end{tabular}

\begin{tabular}{|c|c|c|c|}
\hline \multicolumn{3}{|c|}{ SEQUÊNCIA DIDÁTICA: RJ } & ATIVIDADE: 7 Inserindo figuras - Câmera B \\
\hline \multicolumn{3}{|c|}{ Pesquisadora: Heloisa Jordão } & Professora colaboradora: E. \\
\hline \multicolumn{3}{|c|}{ Ambiente: Lab. Info. } & Total de gravação: 32' \\
\hline Data: 04/10/16 & \multicolumn{2}{|c|}{ Mídia: 3C_041016_b } & Total a ser transcrito: $17^{\prime}$ aos $31^{\prime}$ - vários focos de interesse \\
\hline
\end{tabular}




\section{Mapeamento:}

\begin{tabular}{|c|c|c|c|c|c|c|}
\hline Cam & \multirow[t]{2}{*}{ EVENTO } & \multirow{2}{*}{$\begin{array}{l}\text { TEMPO } \\
\text { min'seg" } \\
\text { Arquivo }\end{array}$} & \multicolumn{3}{|c|}{ Elementos da interação } & RESUMO NARRATIVIZADO \\
\hline 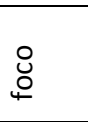 & & & OBJETO DE ENSINO & $\begin{array}{l}\text { INSTRUMENTO } \\
\text { DIDÁTICO }\end{array}$ & $\begin{array}{c}\text { FORMAS } \\
\text { SOCIAIS DE } \\
\text { TRABALHO }\end{array}$ & \\
\hline $\begin{array}{l}\bar{\pi} \\
\bar{d} \\
0\end{array}$ & $\begin{array}{l}\text { Preparação/ } \\
\text { desenvolvimento } \\
\text { no coletivo }\end{array}$ & $\begin{array}{l}0^{\prime} \text { até os } 10^{\prime} \\
\text { idem mídia } \\
\text { A }\end{array}$ & & & $M / Q$ & $\begin{array}{l}\text { - Idem mídia A. só altera o foco (neste arquivo é possível acompanhar a leitura dos } \\
\text { alunos na tela) }\end{array}$ \\
\hline & Descartar & $10^{\prime}$ ao $14^{\prime}$ & & & $\mathrm{D}$ & - alunas não encontram o doc e ficam brincando... sem relação com o conteúdo \\
\hline$\frac{\frac{\pi}{0}}{\frac{0}{7}}$ & $\begin{array}{l}\text { Desenvolvimento } \\
\text { da tarefa em } \\
\text { dupla - Luiz } \\
\text { Keila }\end{array}$ & $\begin{array}{l}14^{\prime} 20^{\prime \prime} \\
27^{\prime} 00^{\prime \prime}\end{array}$ & $\begin{array}{l}\text { - Revisão da escrita a } \\
\text { partir da inserção das } \\
\text { figuras. } \\
\text { - Continuação da } \\
\text { produção de texto } \\
\text { - Ortografia } \\
\text { - Diagramação }\end{array}$ & $\begin{array}{l}\text { - editor de texto } \\
\text { Word } \\
\text { - fotos/figuras }\end{array}$ & $\mathrm{D}$ & $\begin{array}{l}\text { - Alunos revisam o que já foi produzido } \\
\text { - } 17 \text { ' } 40 \text { prof regula localmente, lê o que já foi produzido e problematiza questões } \\
\text { de construção composicional e ortografia. } \\
\text { - Alunos continuam a produção inserindo mais informações e figuras. } \\
\text { - Alunos discutem problemas de ortografia } \\
23^{\prime} 22^{\prime \prime} \text { - Alunos enfrentam problema de diagramação e organização textual. } \\
\text { Professora regula }\end{array}$ \\
\hline$\frac{\frac{\pi}{0}}{\frac{2}{3}}$ & $\begin{array}{l}\text { Desenvolvimento } \\
\text { da tarefa em } \\
\text { dupla: }\end{array}$ & $\begin{array}{l}27^{\prime} 00 \\
31^{\prime} 00\end{array}$ & $\begin{array}{l}- \text { (RE) planejamento } \\
\text { da escrita }\end{array}$ & $\begin{array}{l}\text { - Cartas do jogo } \\
\text { - simulação (prática } \\
\text { do jogo) }\end{array}$ & D & $28^{\prime} 30^{\prime \prime}$ prof regula localmente, lê o que já foi produzido e problematiza \\
\hline
\end{tabular}




\begin{tabular}{|c|c|c|c|}
\hline SEQUÊNCIA DID & RJ & Turma: $3 \circ \mathrm{C}$ & ATIVIDADE: 7 Inserindo figuras \\
\hline \multicolumn{3}{|c|}{ Pesquisadora: Heloisa Jordão } & Professora colaboradora: E. \\
\hline \multicolumn{3}{|c|}{ Ambiente: Lab. Info } & Total de gravação: 32' \\
\hline Data: 04/10/16 & \multicolumn{2}{|c|}{ Mídia: 3C_041016_a } & Total a ser transcrito: $0^{\prime}$ a $1^{\prime \prime}-10^{\prime} 00^{\prime \prime}$ até $11^{\prime}-15^{\prime}$ ao $16^{\prime}-21^{\prime}$ ao $30^{\prime}$ \\
\hline
\end{tabular}

\section{Mapeamento:}

\begin{tabular}{|c|c|c|c|c|c|c|}
\hline Cam & \multirow[t]{2}{*}{ EVENTO } & \multirow{2}{*}{$\begin{array}{l}\text { TEMPO } \\
\text { min'seg" } \\
\text { Arquivo }\end{array}$} & \multicolumn{3}{|c|}{ Elementos da interação } & \multirow[t]{2}{*}{ RESUMO NARRATIVIZADO } \\
\hline 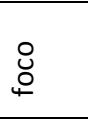 & & & OBJETO DE ENSINO & $\begin{array}{l}\text { INSTRUMENTO } \\
\text { DIDÁTICO }\end{array}$ & $\begin{array}{l}\text { FORMAS } \\
\text { SOCIAIS DE } \\
\text { TRABALHO }\end{array}$ & \\
\hline $\begin{array}{l}\overline{0} \\
\frac{0}{0} \\
00\end{array}$ & abertura & $\begin{array}{l}0 \\
0 \prime 20^{\prime \prime} \\
0 \prime 50^{\prime \prime}\end{array}$ & $\begin{array}{l}\text { - Produção de texto } \\
\text { injuntivo }\end{array}$ & $\begin{array}{l}\text { - discurso da } \\
\text { professora } \\
\text { - telas bloqueadas }\end{array}$ & M & $\begin{array}{l}\text { Professora recupera e projeta brevemente os passos da SD de modo a localizar } \\
\text { temporalmente a atividade do dia. }\end{array}$ \\
\hline $\begin{array}{l}\overline{0} \\
\frac{0}{0} \\
00\end{array}$ & $\begin{array}{l}\text { Explicação da } \\
\text { atividade }\end{array}$ & $\begin{array}{l}0 \prime 50^{\prime \prime} \\
10^{\prime} 00^{\prime \prime}\end{array}$ & $\begin{array}{l}\text { - inserir figuras na RJ. } \\
\text { - escrita de legenda } \\
\text { Tec: renomear } \\
\text { documento } \\
\text { Tec: abrir pasta no W. E. }\end{array}$ & $\begin{array}{l}\text { - explicação passo a } \\
\text { passo } \\
\text { - exemplificação } \\
\text { - texto projetado na } \\
\text { tela dos alunos }\end{array}$ & $Q$ & $\begin{array}{l}\text { - ao longo de quase } 10 \text { minutos a professora explica como são os procedimentos } \\
\text { para inserir uma figura de modo que seja integrada ao conteúdo do texto injuntivo. }\end{array}$ \\
\hline$\frac{\stackrel{n}{0}}{\frac{0}{2}}$ & $\begin{array}{l}\text { Evelyn C. } \\
\text { Gui Pesc. }\end{array}$ & $\begin{array}{l}10^{\prime} 00^{\prime \prime} \\
13^{\prime} 00^{\prime \prime}\end{array}$ & $\begin{array}{l}\text { - inserindo figuras } \\
\text { - produção de texto }\end{array}$ & - editor de texto word & $\mathrm{D}$ & $\begin{array}{l}\text { - Ao ler a produção da dupla a professora reformula a tarefa, salientando que além } \\
\text { de inserir as figuras, talvez fosse necessário que algumas duplas continuassem a } \\
\text { produção textual. }\end{array}$ \\
\hline$\frac{\frac{\pi}{0}}{\frac{0}{7}}$ & problema & $\begin{array}{l}15^{\prime} 00^{\prime \prime} \\
18^{\prime} 25^{\prime \prime}\end{array}$ & $\begin{array}{l}\text { - inserindo figuras } \\
\text { - produção de texto }\end{array}$ & - editor de texto word & $D$ & Surge um problema com o editor de texto e pedem ajuda a prof $\mathrm{E}$. \\
\hline$\frac{\frac{10}{0}}{\frac{0}{7}}$ & $\begin{array}{l}\text { continuando } \\
\text { a redação }\end{array}$ & $\begin{array}{l}21^{\prime} 00^{\prime \prime} \\
23^{\prime} 00^{\prime \prime} \text { até } \\
26^{\prime} 00\end{array}$ & $\begin{array}{l}\text { - textualização } \\
\text { - ortografia } \\
\text { - coesão }\end{array}$ & - editor de texto word & $\mathrm{D}$ & $\begin{array}{l}\text { A partir de feedback dado pela professora alunos conseguem continuar a produção } \\
\text { escrita. } 23^{\prime} 00^{\prime \prime} \text { aluna faz reflexões interessantes no momento que segue com a } \\
\text { textualização. }\end{array}$ \\
\hline
\end{tabular}




\begin{tabular}{|c|c|c|c|c|c|c|}
\hline 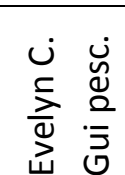 & $\begin{array}{l}\text { Desenv. Da } \\
\text { tarefa: } \\
\text { Produção e } \\
\text { Revisão }\end{array}$ & $\begin{array}{l}26^{\prime} 00^{\prime \prime} \\
30^{\prime} 00^{\prime \prime}\end{array}$ & $\begin{array}{l}\text { - Revisão } \\
\text { - Coerência }\end{array}$ & - editor de texto word & $\mathrm{D}$ & $\begin{array}{l}\text { - Alunos revisam e discutem o próprio texto (mais voltados para questões de } \\
\text { coerência) } \\
\text { - Aos } 27^{\prime} 00^{\prime \prime} \text { prof E. realiza regulação local }\end{array}$ \\
\hline
\end{tabular}




\begin{tabular}{|l|l|l|}
\hline SEQUÊNCIA DIDÁTICA: RJ & Turma: 3 B & ATIVIDADE: 9 - Vocabulário \\
\hline Pesquisadora: Heloisa Jordão & Professora colaboradora: J. \\
\hline Ambiente: Lab. Info & Total de gravação: 26’00” \\
\hline Data: 04/11/2016 & Mídia: 3B_041116_a & Total a ser transcrito: 0 \\
\hline
\end{tabular}

\section{Mapeamento:}

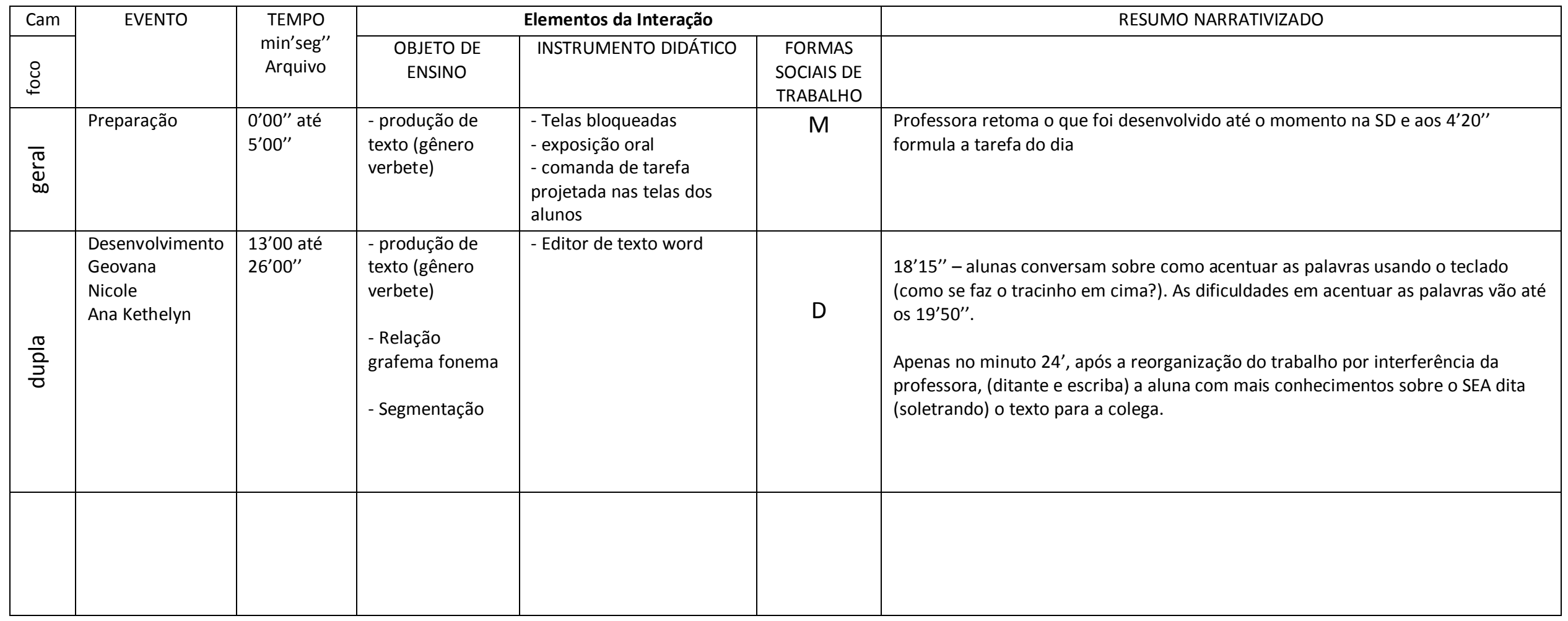




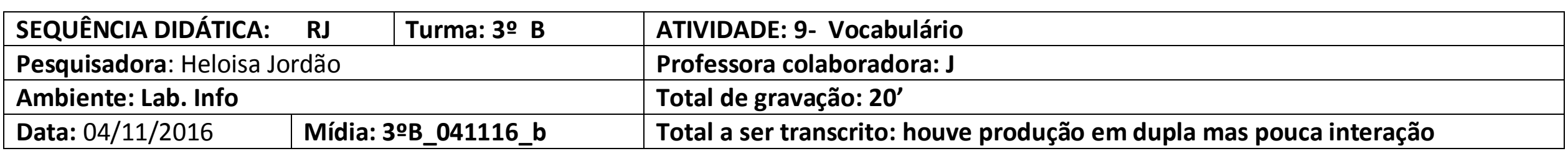

Mapeamento:

\begin{tabular}{|c|c|c|c|c|c|c|}
\hline Cam & \multirow[t]{2}{*}{ EVENTO } & \multirow{2}{*}{$\begin{array}{l}\text { TEMPO } \\
\text { min'seg" } \\
\text { Arquivo }\end{array}$} & \multicolumn{3}{|c|}{ Elementos da interação } & RESUMO NARRATIVIZADO \\
\hline$\stackrel{8}{\circ}$ & & & $\begin{array}{l}\text { OBJETO DE } \\
\text { ENSINO }\end{array}$ & INSTRUMENTO DIDÁTICO & $\begin{array}{c}\text { FORMAS } \\
\text { SOCIAIS DE } \\
\text { TRABALHO }\end{array}$ & \\
\hline $\begin{array}{l}\frac{\pi}{0} \\
\frac{2}{2}\end{array}$ & $\begin{array}{l}\text { Desenvolvimento } \\
\text {-Alexandre } \\
\text { - Diego }\end{array}$ & $\begin{array}{l}3^{\prime} 00^{\prime \prime} \text { até } 0 \\
18^{\prime}\end{array}$ & $\begin{array}{l}\text { - Produção de } \\
\text { texto (gênero } \\
\text { verbete) } \\
\text { - Planejamento } \\
\text { - textualização }\end{array}$ & - Editor de texto & D & $\begin{array}{l}\text { A organização do trabalho na dupla está bem delimitada mas não há muita } \\
\text { interação sobre o desenvolvimento do conteúdo temático e/ou questões } \\
\text { ortográficas. OBS: apesar das conversas estarem repletas de tópicos que } \\
\text { desviam da tarefa, os alunos produzem os } 5 \text { verbetes propostos ao incício da } \\
\text { aula. }\end{array}$ \\
\hline & & & & & & \\
\hline & & & & & & \\
\hline
\end{tabular}




\begin{tabular}{|l|l|l|}
\hline SEQUÊNCIA DIDÁTICA: RJ & Turma: 3o C & ATIVIDADE: 9 - Vocabulário \\
\hline Pesquisadora: Heloisa Jordão & Professora colaboradora: E. \\
\hline Ambiente: Lab. Info & Total de gravação: 32' \\
\hline Data: 04/11/2016 & Mídia:3oC_041116_a & Total a ser transcrito: 20' ao 21' 50 - 25' ao 32' \\
\hline
\end{tabular}

\section{Mapeamento:}

\begin{tabular}{|c|c|c|c|c|c|c|}
\hline Cam & \multirow[t]{2}{*}{ EVENTO } & \multirow{2}{*}{$\begin{array}{l}\text { TEMPO } \\
\text { min'seg" } \\
\text { Arquivo }\end{array}$} & \multicolumn{3}{|c|}{ Elementos da interação } & RESUMO NARRATIVIZADO \\
\hline$\underset{\mathscr{O}}{\longleftarrow}$ & & & OBJETO DE ENSINO & INSTRUMENTO DIDÁTICO & $\begin{array}{c}\text { FORMAS } \\
\text { SOCIAIS DE } \\
\text { TRABALHO }\end{array}$ & \\
\hline $\begin{array}{l}\overline{0} \\
\overline{0} \\
00\end{array}$ & Preparação & $\begin{array}{l}0^{\prime} 00^{\prime \prime} \text { até } \\
7^{\prime} 30^{\prime \prime}\end{array}$ & $\begin{array}{l}\text { Produção de texto } \\
\text { (gênero verbete) }\end{array}$ & $\begin{array}{l}\text { - Telas bloqueadas } \\
\text { - exposição oral } \\
\text { - comanda de tarefa } \\
\text { projetada nas telas dos } \\
\text { alunos }\end{array}$ & $\begin{array}{c}\mathrm{M}- \\
\text { exposição } \\
\text { do professor }\end{array}$ & Rememora o que já foi desenvolvido na SD e formula a tarefa do dia \\
\hline$\frac{\frac{n}{\pi}}{\frac{0}{0}}$ & $\begin{array}{l}\text { Desenvolvimento } \\
\text { em duplas: } \\
\text { - Matheus } \\
\text { Salvino } \\
\text { - Emily }\end{array}$ & $\begin{array}{l}8^{\prime} 15^{\prime \prime} \text { até } \\
32^{\prime}\end{array}$ & $\begin{array}{l}\text { - Textualização, } \\
\text { - Planejamento } \\
\text { - revisão } \\
\text { - Segmentação } \\
\text { - Ortografia } \\
\text { - Artigo } \\
\text { definido/indefinido }\end{array}$ & $\begin{array}{l}\text { - Tarefa em editor de } \\
\text { texto word }\end{array}$ & D & $\begin{array}{l}16^{\prime} 40^{\prime \prime} \text { reflexões breves sobre hipersegmentação (p.e. com meça) } \\
\text { OBS (18'38") os alunos desenvolveram uma estratégia: quando o corretor } \\
\text { ortográfico do Word aponta problemas eles grafam novamente a palavra, } \\
\text { utilizando as mesmas letras, apenas utilizando maiúsculas (o corretor, assim } \\
\text { entende que é uma sigla e não aponta o problema ortográfico). (observe que } \\
\text { manejam bem o uso da tecla caps lock, o que não se torna um problema para } \\
\text { a dupla) } \\
\text { REVISAO: Aos } 20^{\prime} \text { o aluno aponta a troca de G - C em 'gruda' e lembra a } \\
\text { marcação do corretor “por isso que estava errado" (até o } 21^{\prime} 50^{\prime \prime} \text { ) } \\
\text { Aos } 23^{\prime} 30^{\prime} \text { AE comete um erro relacionado ao princípio acrofônico (para } \\
\text { grafar /GA/ insere a letra H, digitando /GHANHAS/ } \\
\text { Aos } 25^{\prime} \text { há mais interação entre a dupla planejando e textualizando um } \\
\text { verbete (até } 32^{\prime} \text { ) (observe a repetição de jogar/jogadores, oscilação entre } \\
\text { que/quem }\end{array}$ \\
\hline
\end{tabular}




\begin{tabular}{|l|l|l|}
\hline SEQUÊNCIA DIDÁTICA: RJ & Turma: 3o C & ATIVIDADE: 9 - Vocabulário \\
\hline Pesquisadora: Heloisa Jordão & Professora colaboradora: E \\
\hline Ambiente: Lab. Info & Total de gravação: 21'50" \\
\hline Data: 04/11/2016 & Mídia:3ㅇ_041116_b & Total a ser transcrito: dos 11'50" até os 15' \\
\hline
\end{tabular}

\section{Mapeamento:}

\begin{tabular}{|c|c|c|c|c|c|c|}
\hline Cam & \multirow[t]{2}{*}{ EVENTO } & \multirow{2}{*}{$\begin{array}{l}\text { TEMPO } \\
\text { min'seg" } \\
\text { Arquivo }\end{array}$} & \multicolumn{3}{|c|}{ Elementos da interação } & RESUMO NARRATIVIZADO \\
\hline 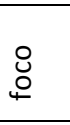 & & & OBJETO DE ENSINO & $\begin{array}{l}\text { INSTRUMENTO } \\
\text { DIDÁTICO }\end{array}$ & $\begin{array}{c}\text { FORMAS } \\
\text { SOCIAIS DE } \\
\text { TRABALHO } \\
\end{array}$ & \\
\hline$\frac{n}{\frac{n}{0}}$ & $\begin{array}{l}\text { Desenvolvimento } \\
\text { em duplas } \\
\text { - Nicolas Matos } \\
\text { - Roberta }\end{array}$ & $3^{\prime} 00^{\prime \prime}$ & $\begin{array}{l}\text { - produção de texto } \\
\text { (verbete). } \\
\text { - Revisão } \\
\text { - Planejamento } \\
\text { - plural/singular }\end{array}$ & $\begin{array}{l}\text { - folha de tarefa } \\
\text { (editor de texto Word) }\end{array}$ & $\mathrm{D}$ & $\begin{array}{l}\text { Após a regulação da prof aos } 6^{\prime} \text { uma integrante da dupla } \\
\text { faz a leitura, diversas vezes, revisando questões } \\
\text { relacionadas a coerência textual } \\
\text { (apesar de alguns momentos interessantes, há pouca } \\
\text { interação) }\end{array}$ \\
\hline & $\begin{array}{l}\text { Desenvolvimento } \\
\text { em duplas } \\
\text { - Nicolas Matos } \\
\text { - Roberta }\end{array}$ & $\begin{array}{l}11^{\prime} 50 \\
12^{\prime} 00 \\
13^{\prime} 30^{\prime \prime}\end{array}$ & $\begin{array}{l}\text { - Revisão/Ortografia } \\
\text { - Textualização } \\
\text { - revisão/ Plural }\end{array}$ & - Editor de texto & $\mathrm{D}$ & $\begin{array}{l}\text { - Ao realizar a leitura AR aponta ao colega que digitou } \\
\text { 'pesso' em lugar de 'pessoa' } \\
\text { - Textualização 12': AR dita a definição mas AN ignora } \\
\text { completamente e redige a sua maneira. } \\
\text { - Acompanhando a escrita do colega AR aponta que faltou } \\
\text { concordância numeral "duas pessoas" }\end{array}$ \\
\hline
\end{tabular}

